\author{
UNIVERSIDADE DE SÃO PAULO \\ FACULDADE DE FILOSOFIA, LETRAS E CIÊNCIAS HUMANAS \\ DEPARTAMENTO DE FILOSOFIA \\ PROGRAMA DE PÓS-GRADUAÇÃO EM FILOSOFIA
}

\title{
Thiago Dias
}

\section{Totalitarismo, tempo e ação: uma leitura de $A$ condição humana de Hannah Arendt}




\section{Thiago Dias}

Totalitarismo, tempo e ação: uma leitura de $A$ condição humana de Hannah Arendt

(versão corrigida)

Tese apresentada ao Programa de PósGraduação em Filosofia do Departamento de Filosofia da Faculdade de Filosofia, Letras e Ciências Humanas da Universidade de São Paulo, para obtenção do título de Doutor em Filosofia sob a orientação da Profa. Dra. Marilena de Souza Chauí. 
Folha de Aprovação

DIAS, T. Totalitarismo, tempo e ação: uma leitura de $A$ condição humana de Hannah Arendt. 2008. Tese (Doutorado) - Faculdade de Filosofia, Letras e Ciências Humanas. Departamento de Filosofia, Universidade de São Paulo, São Paulo, 2018.

Banca examinadora:

Professor(a) $\operatorname{Dr}(a)$

Instituição:

Julgamento:

Assinatura:

Professor(a) $\operatorname{Dr}(a)$

Instituição:

Julgamento:

Assinatura:

Professor(a) $\operatorname{Dr}(a)$.

Instituição:

Julgamento:

Assinatura:

Professor(a) $\operatorname{Dr}(a)$.

Instituição:

Julgamento:

Assinatura:

Professor(a) $\operatorname{Dr}(a)$.

Instituição:

Julgamento:

Assinatura: 
Para o Leo, que é lindo! 


\section{RESUMO}

DIAS, T. Totalitarismo, tempo e ação: uma leitura de $A$ condição humana de Hannah Arendt. 2018. 189 f. Tese (Doutorado) - Faculdade de Filosofia, Letras e Ciências Humanas. Departamento de Filosofia, Universidade de São Paulo, São Paulo, 2018.

Partindo da ideia de que, para Hannah Arendt, Origens do totalitarismo não esgota a questão do totalitarismo, a tese pretende mostrar o primeiro passo dado pela autora no aprofundamento da questão. A argumentação se inicia com a afirmação arendtiana de que os campos de concentração funcionaram como laboratórios onde até mesmo a personalidade e a espontaneidade dos seres humanos foram concebidas como coisas e, portanto, como sujeitas ao conhecimento. Esta constatação colocou o problema do humano no centro do pensamento da autora. Ao confirmar uma antiga suspeita contra a tradição de filosofia política, Arendt se engajou em sua desmontagem servindo-se de certa análise de alguns filósofos pós-hegelianos (sobretudo Marx) e da crítica ao procedimento de differentia specifica para a determinação da essência do ser humano. Em um passo seguinte, lançou-se à formulação de uma nova maneira de pensar o humano e, para evitar o recurso a essências, apoiou-se sobre as diferentes temporalidades das atividades humanas. O resultado deste movimento é $A$ condição humana, livro em que a vita activa é apresentada em termos temporais e o conceito de ação é formulado como uma temporalidade aberta ancorada na pluralidade. Isto faz do conceito de ação um entrave teórico ao totalitarismo, uma vez que insere o indeterminado no centro do pensar político tornando impossível o conhecimento do agir.

Palavras-chave: Arendt, totalitarismo, tempo, ação, Marx 


\begin{abstract}
DIAS, T. Totalitarianism, Time and Acrion: An Interpretation of Hannah Arendt's The Human Condition. 2018. 189 f. Thesis (Doctoral) - Faculdade de Filosofia, Letras e Ciências Humanas. Departamento de Filosofia, Universidade de São Paulo, São Paulo, 2018.

Since for Hannah Arendt the question of totalitarianism is not completely solved with The Origins of Totalitarianism, I intend to show her first steps toward a deeper level of this question. I start with her claim that concentration camps were comparable to laboratories in which even men's personality and spontaneity were conceived as sheer things, thus being subject to knowledge. This observation leads the problem of human to the center of her thought. After confirming a suspicion harbored against the tradition of political philosophy, Arendt binds herself to dismantle the tradition, a task carried out through an analysis of post-hegelian thinkers (specially Marx) and the critique of differentia specifica as a proceeding to determine human beings' essence. Her following step was the formulation of a new way to think about human and, in order to avoid the use of essences, she leans on the different temporalities of human activities. The outcome of this movement is The Human Condition, a book in which vita activa is described in temporal terms and the concept of action structured on an open temporality based on plurality. The concept of action became a theoretical blockade against totalitarianism as it places the indeterminate in the center of political thinking thus making it impossible to know a priori human action.
\end{abstract}

Key Words: Arendt, totalitarianism, time, action, Marx. 


\section{Sumário}

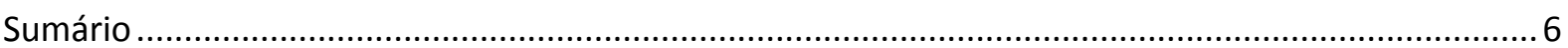

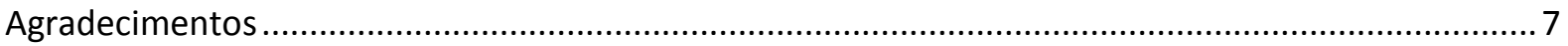

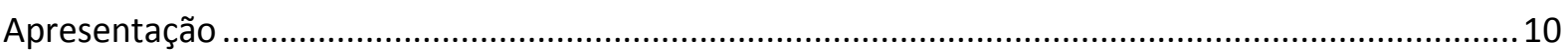

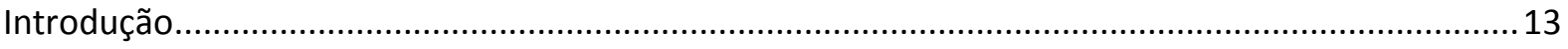

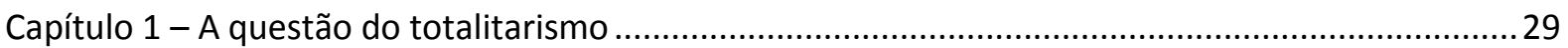

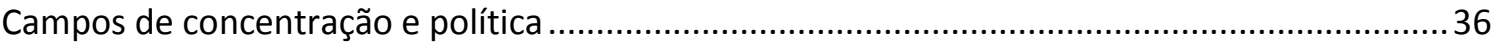

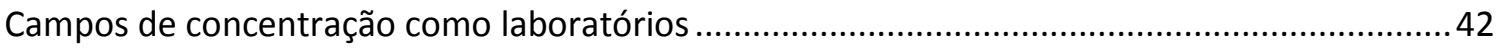

Capítulo 2 - Desmontagem da tradição .................................................................................... 51



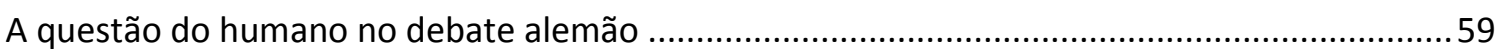

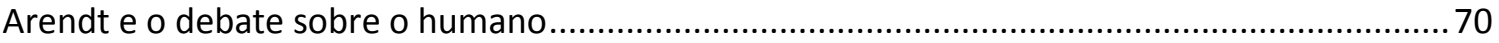

Parte II: Differentia specifica, um elemento totalitário da tradição.............................................. 76

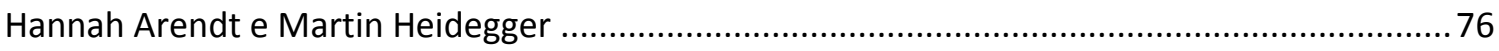

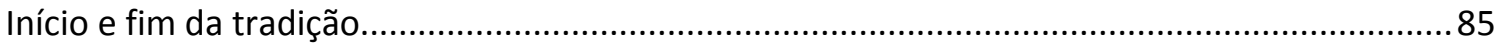

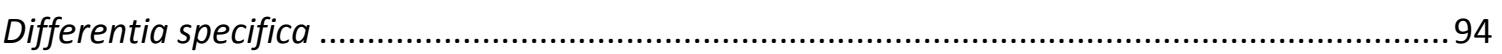





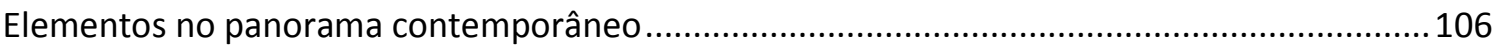

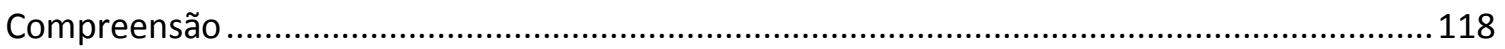

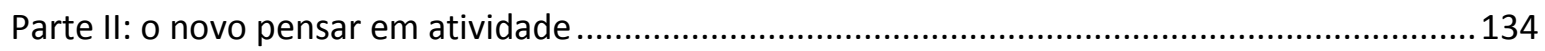

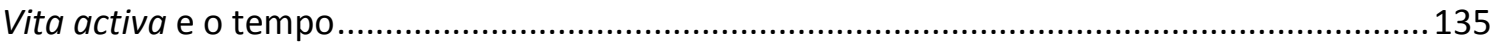

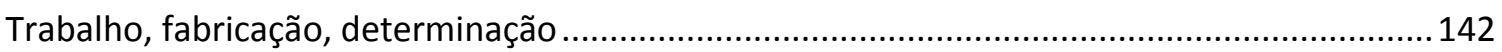

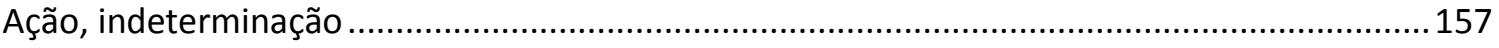

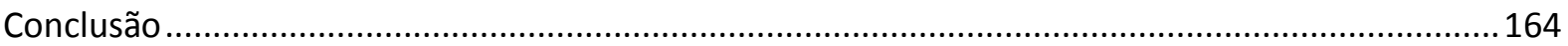

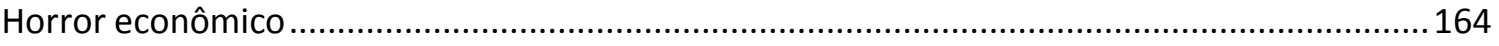

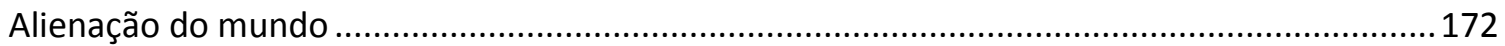

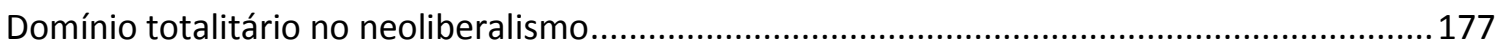

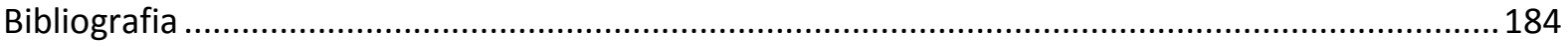




\section{Agradecimentos}

Embora muito do trabalho de pesquisa deva ser feito solitariamente, esta tese deve muito a várias pessoas que tive a sorte de ter ao redor durante os anos dedicados a ela.

Agradeço em primeiro lugar à querida professora Marilena Chauí, a quem devo uma orientação rigorosa, afetuosa e generosíssima, além de um exemplo vivo de acadêmica de altíssimo nível e de intelectual de grande porte.

Ao longo do período de pesquisa, contei também com a felicidade de ser acolhido pelo Centro de Estudos Hannah Arendt, coordenado pela professora Claudia Perrone-Moisés e pela Laura Mascaro, onde trabalho ao lado da Luciana Garcia, da Ludmyla Franca e da Patrícia Oliveira. Agradeço também ao professor Celso Lafer, patrono dos estudos arendtianos no Brasil, pela contribuição com o Centro.

Em uma curta, mas proveitosa estadia de pesquisa na Alemanha, fui muito bem recebido pelo professor Wolfgang Heuer, com quem pude conversar sobre ideias, dúvidas e planos em Berlin, e pela simpática e apaixonada Cristina Harckensee-Roth, com quem passei uma animada e proveitosa tarde de pesquisa nos arquivos do Hannah Arendt-Zentrum de Oldenburg, em uma visita que contou com o apoio do professor Johann Kreuz e de Oliver Bruns. Devo agradecer também a ajuda de Ludmyla Franca para enfrentar o rigoroso inverno alemão.

$\mathrm{Na}$ banca de qualificação, tive o privilégio de contar com a leitura atenta da professora Silvana Ramos e do professor Alberto de Barros, que indicaram vários caminhos possíveis influenciando diretamente minhas decisões a respeito da direção que o trabalho tomaria a partir de então. Agradeço ainda aos professores que participaram da banca de defesa, Silvana Ramos, novamente, Maria das Graças, Bethânia Assy e Adriano Correia, que realizaram leituras cuidadosas e divergentes da tese oferecendo questões que permanecerão comigo ainda por muito tempo.

Eu devo muito ao grupo de estudos Espinosanos, em cujas afetuosas reuniões semanais pude discutir trechos deste trabalho e, sobretudo, amadurecer filosoficamente por meio de nossas animadas conversas sobre vários temas e autores realizadas na sala da reunião, nos corredores e no café da tia Bia, cuja equipe também merece agradecimentos.

Com a equipe dos Cadernos de Ética e Filosofia Política, ou melhor, com os amigos dos cadernos, troquei ideias, afetos, risos e lágrimas ao longo de quase dez anos (!) de amistosa convivência e intenso aprendizado sobre o funcionamento da academia. 
À professora Maria das Graças dedico um agradecimento especial pelo generoso acolhimento iniciado no primeiro semestre da graduação e intensificado ao longo dos anos de pós-graduação. Ao professor Luís César Oliva, agradeço pela constante e generosa disponibilidade.

Agradeço a todos os meus professores na graduação e na pós-graduação. Os professores Vladimir Safatle, Renato Janine Ribeiro, Ruy Fausto, Olgária Matos, Sérgio Cardoso e Brigitte Weiffen contribuíram com meu trabalho ao longo da pós-graduação, embora não necessariamente me dando aulas. Agradeço também ao pessoal da secretaria, sobretudo à Mariê, à Geni e à Luciana, e a todas as pessoas que mantiveram e mantém o N.E.L.E. em funcionamento por tantos anos, em especial àqueles que foram meus professores ali: Luciano Laface (francês), Isabel Fragelli, Fábio Pimentel e Eduardo Altheman (alemão).

Aos vários estudiosos da obra de Arendt espalhados pela América do Sul que se reúnem anualmente nos Encontros Arendt, devo agradecer pelo aprendizado, pela possibilidade de expor partes desta pesquisa, pelos vários momentos agradáveis e pela fraternidade.

Muito deste trabalho foi feito em bibliotecas públicas, em especial na Biblioteca Florestan Fernandes e na Biblioteca municipal Mario de Andrade, mas também na biblioteca de filologia da FU-Berlin, na da FEA-USP e na da FEUSP. Fica aqui expressa minha gratidão.

Agradeço também ao CNPq e ao DAAD por financiarem meu trabalho.

Ao longo de todos estes anos de FFLCH convivi com bons colegas, fiz amigos e alguns grandes amigos. É difícil listar todo mundo, mas devo registrar minha dívida especial às longas conversas, arendtianas ou não, com a Mari e com a Laura, duas das pessoas mais próximas de mim, ao impacto que as discussões com o Samuel exercem sobre mim, ao amargor dos cafés tomados com o Fernando, à longa amizade com o Admárcio. Apesar da distância, a amizade do Heitor e do Bruno também foram especialmente importantes ao longo destes anos.

Agradeço à Nice, ao Vita, ao Rô e ao Tuca, família maravilhosa em que tive a sorte de nascer e que amo intensamente, malgrado as distâncias impostas pela vida.

São cada vez mais comuns os relatos de distúrbios psicológicos, como depressão e ansiedade aguda, vinculados à pós-graduação, sobretudo nas condições atuais da academia, que estimulam a competição e o consequente isolamento entre as pessoas. Percebi (e percebo) 
estas pressões em vários dos meus colegas, marcados pelo risco constante de algum tipo de queda ou de quebra. No meu caso, muito felizmente, esta tensão não resultou em nada muito grave, em nada que uma barra de chocolate ou uma dose de uísque não resolvesse. Eu atribuo esta sorte ao fato de ter contado com um lar que me acolhe e exige que eu não me entregue integralmente ao trabalho. Eu devo, portanto, um agradecimento muito especial à Juliana, companheira ao longo de todos estes anos, que formou comigo este refúgio. Devo também um agradecimento ao Leo, que dá sentido a absolutamente tudo o que faço desde que ele chegou em minha vida. 


\section{Apresentação}

Todas as vezes que alguma forma de pensamento é materializada em um texto escrito, algo fica para trás. Isto é verdade tanto para as grandes obras do pensamento quanto para as modestas contribuições, como esta tese que o leitor tem em mãos, e é por conta disto que gostaria de apresentar sucintamente o percurso de que esta tese é um momento recente. Com esta ligeira apresentação do movimento que me trouxe até este texto, pretendo não apenas informar a hipótese central do trabalho, mas também mostrar alguns elementos de sua gênese e, sobretudo, justificar alguns limites que o leitor encontrará.

Tomando o projeto de pesquisa apresentado ao programa de pós-graduação como o começo deste movimento, pode-se dizer que o propósito inicial da pesquisa era elaborar uma espécie de comparação entre os pensamentos de Karl Marx e Hannah Arendt. Como meus estudos anteriores tinham sido dedicados à obra arendtiana, a perspectiva adotada era arendtiana, ou seja, o trabalho partiria dos três livros em que Arendt se dedica direta e explicitamente à obra de Marx, A condição humana, Entre passado e futuro e Sobre a revolução, tomaria o conflito entre economia e política como ponto central e, quando possível, apresentaria eventuais respostas marxistas à argumentação arendtiana. A estratégia de estudar filósofos confrontando-os sempre encontra dificuldades em suas diferenças de vocabulário, de pressupostos, de objetivos, de métodos e, embora estivesse ciente disto, notei aos poucos que havia algo mais fundamental a separar os autores em questão, algo que por vezes retirava muito do solo comum que o estudo comparado exige. Isto não impede a realização de um trabalho desta natureza, como provam a existência e a pertinência de vários estudos deste tipo, mas esta dificuldade levou meu interesse a outras paragens, de modo que a ideia de comparação perdeu sua força, uma vez que esta dificuldade se dava, percebi em dado momento, pela decisiva ruptura com a tradição realizada por Arendt, que parecia estabelecer um fosso entre ela e os filósofos da tradição, Marx aí incluso.

Assim, o trabalho sofreu uma inflexão e passou a ser concebido como um estudo sobre a interpretação arendtiana de Marx, concepção que foi rapidamente ampliada pela percepção de que, na trajetória de Arendt, Marx aparece estreitamente vinculado à questão do totalitarismo e ao problema da tradição, o que por sua vez me levou a focalizar a maneira pela qual ela realiza sua crítica à tradição. Esta é a perspectiva atual e, portanto, a que 
organiza esta tese. Esta investigação a respeito do procedimento de Arendt nos conduziu à pergunta a respeito da gênese de A condição humana e, por razões práticas (prazos), reduziu o escopo da tese a este livro adiando a investigação a respeito de Entre passado e futuro e Sobre a revolução.

Enquanto estas mudanças aconteciam, tive a enorme felicidade de participar da formação de um grupo de estudos de filosofia contemporânea no interior do Grupo de Estudos Espinosanos. A iniciativa surgiu do interesse de alguns membros do Espinosanos de ler e discutir autores do século XX, em especial os franceses, e de alguma maneira conjugar esforços de estudos. No interior deste grupo, realizamos a leitura do curso sobre Hegel dado por Alexandre Kojève e, sob o impacto da descoberta de que também Arendt assistiu, ainda que por pouco tempo, aos famosos seminários que deram origem ao livro, formulei uma hipótese de que o Marx de Arendt, que então procurava, era profundamente influenciado por Kojève; não à maneira de Jean-Paul Sartre, que acompanhava o russo bastante de perto, mas contra Kojève, especialmente contra a ideia de fim da história que estaria no Marx de Arendt.

Pouco tempo depois, em 2015, outra leitura realizada no grupo marcou profundamente o trajeto deste trabalho. Refiro-me à leitura de parte da obra de Claude Lefort, realizada ao lado de alguns grandes especialistas e que me colocou em contato com a ideia de que o totalitarismo se opõe ao lugar vazio do poder, característico da democracia. Esta oposição entre totalitarismo e o vazio me acompanha desde então, como o leitor notará ao longo da leitura.

Deu-se na sequência disto, uma obscura confluência entre o negativo de Kojève, o nada de Sartre e ao vazio de Lefort trazendo-me a ideia de que a luta arendtiana contra o totalitarismo se faria por meio de alguma forma de indeterminado. A primeira formulação deste encontro um tanto oblíquo se deu na afirmação de que A condição humana continha uma antropologia que trazia em si algo de essencialmente indeterminado. A data do exame de qualificação recaiu sobre este estágio do trabalho, de modo que o texto ali apresentado traz uma abordagem marcada por esta hipótese, que, embora tenha sido bem acolhida pela banca, foi abandonada pouco depois, quando descobri uma censura de Arendt contra Kojève por ele ter tomado a filosofia da existência como uma antropologia.

Esta descoberta me levou a uma releitura relativamente recente de $A$ condição humana tendo em mente a confluência de todas estas ideias e foi neste momento que o tempo apareceu como o elemento capaz de articular todas elas. A condição humana representa o primeiro esforço de aprofundamento da questão do totalitarismo, que se dá pela apresentação, 
baseada em uma firme e cuidadosa desmontagem da tradição, de uma nova maneira de pensar o humano e, consequentemente, a política. Para elaborar este novo pensar, Arendt se apoia nas diferentes temporalidades encontradas na vita activa.

Esta afirmação abre uma perspectiva de leitura muito ampla e tem consequências muito grandes. Como esta formulação só foi alcançada depois de um tempo de pesquisa e amadurecimento não contabilizados pelo prazo imposto desde o início, optei por circunscrever a tese à demonstração desta afirmação deixando de lado muitas de suas consequências. Este recorte, claro está, se deve ao prazo para a "terminar" o trabalho, não à falta de interesse pelas questões, que continuarão comigo ainda por tempo indeterminado. 


\section{Introdução}

É difícil medir a importância do conceito de totalitarismo na história do século XX. Em uma trajetória de idas e vindas ao longo do breve século, ele passou pela pena de vários autores e pelos projetos de vários grupos políticos de posições distintas ou mesmo opostas. Ao recontar a gênese e os descaminhos do termo, Enzo Traverso ${ }^{1}$ nos mostra que o adjetivo totalitario foi criado pelos opositores de Mussolini, interessados em denunciar o caráter absolutista da política do Duce. Confirmando a percepção de seus críticos, Mussolini incorporou o adjetivo apropriando-se positivamente tanto da ideia quanto do termo. O célebre bordão Tutto nello Stato, niente al di fuori dello Stato, nulla contro lo Stato explicita a ideia de que o fascismo era concebido como totalitário, no sentido de representar um esforço de ampliação do Estado para todas as esferas da vida social. Esta primeira reviravolta no papel do termo no debate público estabeleceu um vínculo profundo entre os termos "totalitário" e "fascista"; a ascensão de Hitler ao poder e o uso da locução totale Staat por parte do movimento nazista apertou estes laços tornando "evidente" a quase identidade entre "fascista", "nazista" e "totalitário" ao longo dos anos 1930.

Apesar desta apropriação feita por estes dois ditadores, o termo manteve seu caráter predominantemente negativo, pois circulou mais entre quem se mobilizou na luta contra o fascismo. No entanto, a situação se confundiu bastante a partir de 1945, com o fim dos regimes de Hitler e de Mussolini e com a permanência do regime de Stalin. A dificuldade se deve ao fato de Stalin ter sido o grande adversário dos regimes totalitários alemão e italiano, mas se mostrar agora como líder de um regime que também poderia ser classificado como totalitário, uma vez que o Estado stalinista se ampliava para todas as esferas da vida. $\mathrm{Na}$ aurora do mundo bipolar, o termo passa por uma mutação que o conduz do antifascismo ao anticomunismo, confinando-o consequentemente a um dos polos da Guerra Fria. Utilizado tanto por políticos e autores liberais sérios quanto por certa ralé anticomunista (em especial a estado-unidense e sobretudo durante o macarthismo), "totalitarismo" serviu por décadas para analisar e denunciar o governo da URSS. Por ser capaz de unir conceitualmente os liquidados regimes de Mussolini e Hitler ao vivíssimo regime de Stalin, o termo facilitava então a defesa da liquidação da URSS. Considerando o caráter bipolar do mundo de então, a necessidade de aniquilar o regime de Stalin aparece como o anverso da necessidade de manter e fortalecer a

\footnotetext{
${ }^{1}$ Traverso, Le totalitarisme: le XXe siècle en débat. Paris: Éditions du Seuil, 2001.
} 
ordem ocidental, exemplificada especialmente pelos EUA e pela Alemanha da reconstrução.

O uso ideológico do termo totalitarismo feito pela direita ao longo da Guerra Fria só se fez possível às custas do esquecimento de que o fascismo contou com a simpatia e o apoio das elites tradicionais ao longo dos anos 1920, de que as democracias liberais entraram em colapso nos anos 1930 sem serem capazes de oferecer qualquer obstáculo sério à ascensão do fascismo. Décadas mais tarde, a contradição se tornaria ainda mais evidente com o surgimento de ditaduras impostas ao Terceiro Mundo pelo "mundo livre". Mas estas dificuldades do uso ideológico do termo não impediram sua efetividade na luta pelas mentes e tampouco impediram o surgimento de uma forte resistência contra o termo no interior da esquerda. Do ponto de vista teórico, esta recusa obrigou a esquerda a se esquecer que Trotsky se serviu bastante do termo para criticar a URSS sob Stalin; que, para o marxista Hilferding, "a URSS e a Alemanha nazista repousavam a partir de então [1940] sobre 'economias de Estado totalitárias' pós-capitalistas"; 2 que, para Victor Serge (1945)"[A] primeira condição para o renascimento do socialismo europeu parece ser, portanto, que ele mantenha com lucidez e firmeza uma independência absoluta com relação ao comunismo totalitário."3 Evidenciando a tenacidade desta recusa, Eric Hobsbawn, escrevendo na década de 1990, ainda fazia questão de grafar totalitarismo entre aspas. ${ }^{4}$ Do ponto de vista político, a recusa do termo se associa intimamente à condescendência com que amplos setores da esquerda trataram a URSS, mesmo depois do relatório de Kruschev, mesmo depois da Revolução Húngara, mesmo depois da primavera de Praga.

É neste momento que Hannah Arendt aparece na cena intelectual com a publicação de Origens do totalitarismo. ${ }^{5}$ Embora as qualidades apresentadas pelo livro justifiquem largamente seu status de clássico do século XX, não se pode deixar de notar, no entanto, que outros elementos contribuíram decisivamente para a atenção imediata que lhe foi conferida. O livro foi publicado em inglês, nos EUA, em 1951, e apresentava uma das primeiras elaborações extensas do conceito de totalitarismo; a formulação arendtiana considera que houve apenas dois regimes totalitários propriamente: o de Stálin, ainda vigente, e o de Hitler, já liquidado. À primeira vista, portanto, o livro parece ir ao encontro dos interesses

\footnotetext{
${ }^{2}$ Citado por Traverso, Introduction, p.37

${ }^{3}$ Serge, "Socialisme et totalitarisme", in: Traverso, Le Totalitarisme, p.428

${ }^{4}$ Cf. Hobsbawn, Era dos extremos, pp.116, 359, 559.

${ }^{5}$ Este não é, no entanto, o primeiro livro de Arendt, que publicou sua tese de doutorado, $O$ conceito de amor em Agostinho, em 1929 e se dedicou em seguida à elaboração da biografia de Rahel Varnhagen, trabalho interrompido pela meia noite do século e que só foi
} 
ideológicos da "ordem ocidental", uma vez que contribui para organizar sob um mesmo conceito o governo de Hitler, indefensável sob qualquer ponto de vista, e a URSS, que então contava com inúmeros simpatizantes. Somando-se a isto o fato de a autora ser uma alemã exilada nos EUA e cidadã americana por opção, tem-se todas as condições para uma recepção imediatamente favorável do trabalho de Arendt por um dos polos da disputa e, consequentemente, para uma rejeição automática pelo polo oposto. A esquerda, desconfiando da aproximação conceitual entre Hitler e Stalin feita por esta cidadã americana sobrevivente dos campos de concentração, rejeitou o conceito de totalitarismo e, com ele, toda a obra de Arendt, agora rotulada como pensadora do "mundo livre". 6

O lugar de Arendt no panorama intelectual do século XX é profundamente marcado por esta primeiríssima recepção. Estas marcas não se resumem à consideração de Arendt como uma autora de direita, mas inclui também a ideia de que sua obra se centra, ou mesmo se esgota, no conceito de totalitarismo. ${ }^{7}$ Não é de modo algum surpreendente que esta

terminado décadas mais tarde.

6 Há uma outra resistência ao conceito de totalitarismo, oriunda de certos setores da comunidade judaica para os quais a Shoah tem uma especificidade e esta não é reconhecida quando Hitler é comparado a qualquer outro governante. Robert Solomon Wistrich é um dos representantes desta resistência. Segundo ele, a hostilidade aos judeus se inicia na Antiguidade como uma xenofobia étnico-religiosa comum, destas presentes ao longo de toda a história. Com o surgimento do cristianismo, no entanto, o antissemitismo ganhou uma dimensão teológica e metafísica que se alastrou junto com o cristianismo disseminando ódio contra os judeus por todo o ocidente, inclusive fora do cristianismo, como na URSS e no "mundo árabe" (onde reside o perigo do antissemitismo atualmente). $O$ nazismo e sua "Solução final" são o desenvolvimento mais radical do "mais longo dos ódios" (the longest hatred), não de uma nova forma de governo que vitimou os judeus, mas poderia ter vitimado qualquer outro grupo. Aparentemente, Wistrich não responde diretamente a Arendt, mas ele se opõe claramente à oposição arendtiana entre o "antissemitismo eterno" e o "antissemitismo moderno", ainda que ele reconheça um ponto de inflexão no século XVIII e recuse a ideia de algo intrinsecamente antissemita nos gentios. Não parece abusivo, além disto, imaginar que esta resistência ao conceito de totalitarismo se intensificou com a antipatia, ou mesmo o ódio, que Arendt despertou na comunidade judaica com seu livro sobre Adolf Eichmann.

$\mathrm{Na}$ mesma direção, há também resistência contra os esforços de vincular o Holocausto aos impasses da modernidade, como bem mostra Bauman no início de seu Modernidade e Holocausto.

(Cf. Leibovici \& Roviello, Le pervertissement totalitaire: la banalité du mal selon Hannah Arendt, pp.13-6.; cf. tb. WISTRICH, R. S. Antisemitism: The Longest Hatred. New York: Schocken Books, 1991); Bauman, Z - Modernidade e Holocausto. Rio de Janeiro: Zahar, 1998, pp.19-31.

${ }^{7}$ Elizabeth Young-Bruhel tem razão ao afirmar que "banalidade do mal" funciona como uma frase de efeito (sound bite) capaz de resumir toda a obra de Arendt. No entanto, a crítica de Young-Bruhel não se lança sobre os debates teóricos realizados entre esquerda e direita ao longo da segunda metade do século XX, mas à "novilíngua" presente na imprensa norteamericana no início do século XXI, responsável por análises superficiais que permitem explicar tudo por meio da "banalidade do mal". Para exemplificar, cita o esforço do jornalista 
associação seja feita, uma vez que Arendt, embora não tenha inventado o termo e sequer tenha sido a primeira pensadora importante a se servir dele, foi quem ofereceu o primeiro grande esforço de elevar o termo ao nível do conceito. Mas esta recepção feita no interior da disputa ideológica da Guerra Fria introduziu renitentes obstáculos à sua compreensão profunda, dentre os quais o mais teimoso talvez seja a oposição "totalitarismo versus democracia". Não é difícil encontrarmos ainda hoje a consideração apressada de que o oposto do totalitarismo é a democracia e, ato contínuo, a democracia equivale ao sistema político do "mundo livre". A consequência imediata desta concepção ligeira é que todas as ideias que de alguma forma se opõem à "ordem ocidental" são totalitárias em alguma medida e devem ser combatidas. Mesmo certos leitores qualificados deixam de perceber a amplitude do conceito de totalitarismo precisamente porque se atam à oposição "totalitarismo versus democracia" sem considerar adequadamente as continuidades entre ambas. A passagem de $O$ passado de uma ilusão que François Furet dedica a Origens do totalitarismo e sua autora exemplifica bem esta interpretação ideológica do conceito de totalitarismo e revela a tenacidade de certos marcos estabelecidos pela Guerra Fria.

Publicado em 1996, O passado de uma ilusão apresenta a primeira grande síntese do comunismo realizada depois do fim da URSS. Na parte final do décimo primeiro capítulo do livro, "O comunismo de Guerra Fria", encontramos uma pequena biografia de Arendt com destaque para a gênese e para algumas das teses mais importantes de Origens do totalitarismo, além das nuançadas impressões de Furet a respeito do livro:

Assim vai este livro importante, mas escrito de qualquer jeito (à la diable), feito de peças e pedaços, esticado sobre um período demasiado longo, mal composto; iniciado pela análise do nazismo e terminado com uma teoria política melhor ajustada ao comunismo; afirmando a novidade radical do fenômeno totalitário, mas consagrando mais da metade do trabalho a uma pesquisa pelas origens, limitadas ao lado alemão, aliás; mistura, como [Franz] Neumann, a velha crítica da democracia de massa à genealogia capitalista do fascismo, entrelaçando-a à intuição de [Waldemar] Gurian sobre a inumanidade fundamental dos regimes "ideológicos", mas sem oporlhes a transcendência divina, como ele fez. Embora confuso, peremptório e contraditório, o livro tem sua extensão e seus volteios perdoados pela amarga violência que o habita inteiramente e pela explosão de sua terceira parte. ${ }^{8}$

Além deste balanço próprio, o historiador apresenta ainda algumas características da primeiríssima recepção da obra de Arendt nos EUA, uma recepção que marca sua própria impressão. Em 1953, apenas dois anos depois da publicação de Origens do totalitarismo,

John Fisher Burns em aproximar o julgamento de Adolf Eichmann ao de Saddam Husseim afirmando haver uma passagem "da banalidade à audácia". Cf. Young-Bruhel, Why Arendt Matters, p.1-2; Cf. tb. Burns, "From Banality to Audacity".

${ }^{8}$ Furet, Le passé d'une illusion, p.500-1 — grifos nossos 
realizou-se um colóquio sobre o totalitarismo em Harvard. O evento foi presidido por Carl J. Friedrich, então professor da Escola de Treinamento de Assuntos Civis [Civil Affairs Training School] da Universidade de Harvard e estudioso dos temas relativos à URSS. O evento se deu em meio ao macarthismo, o que levou os organizadores a convidarem apenas pesquisadores da esquerda americana e a recusarem a presença da direita, responsável pelo "anticomunismo histérico do momento". Furet nos conta que, embora não tenha apresentado nada, Arendt assistiu a este colóquio e viu a terceira parte de seu livro ser citada elogiosamente, servindo de referência a pesquisadores presentes. A comparação entre Stalin e Hitler, ou seja, a extensão do conceito de totalitarismo à URSS, foi bem aceita pelos participantes e incorporada a suas pesquisas. O que não se aceitou muito bem do livro foi sua busca pelas origens, seu esforço para mostrar os elementos que cristalizaram na novidade totalitária, donde o interesse exclusivo por sua terceira parte. Este eloquente recorte é sintetizado em uma afirmação de Friedrich destacada por Furet: "As sociedades totalitárias são fundamentalmente comparáveis e são historicamente únicas; por que elas são o que são, nós não sabemos." 9

Um dos resultados do longo trabalho de Friedrich junto a seus alunos é Totalitarismo e autocracia, livro escrito com seu assistente Zbigniev Brzezinski - que depois faria notável carreira acadêmica e se tornaria Conselheiro de Segurança Nacional no governo de Jimmy Carter. Embora tenha sido relativamente pouco lido fora dos EUA, o livro exerceu grande influência no debate americano, talvez por ser tão vinculado a cursos dados em Harvard por mais de uma década. ${ }^{10} \mathrm{O}$ ponto de vista sincrônico expresso na afirmação de Friedrich acima destacada é reafirmado logo na abertura do prefácio: "O presente estudo da ditadura totalitária procura estabelecer uma teoria geral e descritiva desta nova forma de governo. Não pretendemos explicar a causa de seu aparecimento". ${ }^{11}$

Como se sabe, Origens do totalitarismo é um livro longo e dividido em três partes antissemitismo, imperialismo e totalitarismo. As duas primeiras são dedicadas a antecedentes dos regimes de Hitler e de Stalin; a terceira tem um caráter distinto porque oferece uma descrição destes regimes. Sabe-se hoje que a própria Arendt lamentou o termo "origens" no título do livro, uma vez que ele poderia dar a entender que o livro traria um esforço para

\footnotetext{
${ }^{9}$ Furet, Le passé d'une illusion, p.501-2

10 Traverso afirma que a influência deste livro é comparável à de Origens do totalitarismo. Cf. Traverso, Le totalitarisme, pp.60, 65-7 e 472-3. Friedrich e Brzezinski declaram débito especial a alguns "consultores", dentre os quais Franz Neumann e Hannah Arendt.

${ }^{11}$ Friedrich \& Brzezinski, Totalitarismo e autocracia, p.7
} 
apresentar as causas do totalitarismo, o que está longe de ser a intenção da autora. ${ }^{12}$ A edição alemã do livro, traduzida (ou reescrita?) pela própria autora foi intitulada Elemente und Ursprünge totaler Herrschaft [Elementos e origens do domínio total], talvez em um esforço para atenuar esta possível primeira impressão e dissolver a expectativa por causas que expliquem o fenômeno totalitário. Embora Furet também tenha visto o risco da "causalidade" no trabalho de Arendt, ${ }^{13}$ esta não é, no entanto, a razão de ele e a esquerda americana presente no colóquio recusarem as duas primeiras partes do livro, dedicadas às origens do fenômeno totalitário. As razões deste recorte podem ser compreendidas a partir de teses de $O$ passado de uma ilusão.

De acordo com Furet, a gênese do totalitarismo deve ser buscada no início dos movimentos fascistas e comunistas do século XX, que com o fim da Primeira Guerra encontraram as condições para que certas paixões revolucionárias pudessem se organizar politicamente.

\begin{abstract}
Destas paixões, nascidas (filles) da democracia moderna e exaltadas para devastar a terra que as alimenta, a mais antiga, a mais constante e a mais poderosa é o ódio à burguesia. Ela ocorre ao longo de todo o século XIX antes de encontrar seu coroamento (point d'orgue) em nossa época, uma vez que a burguesia, sob nomes diferentes, constitui para Lênin e para Hitler o bode expiatório dos males do mundo. (...) A burguesia é o outro nome da sociedade moderna. ${ }^{14}$
\end{abstract}

Nascida da luta contra o Ancien Régime, a burguesia traz consigo uma forma política própria, que ela chama de democracia. Este regime político aparece como universal, como realização das aspirações de todos os homens e se estabelece pelo ocidente à medida que a burguesia amplia seus domínios econômico e social, sempre portando uma mensagem de liberdade e igualdade. O problema todo é que a burguesia e sua democracia cumprem apenas metade do que prometem, uma vez que sua ordem repõe nos campos econômico e social a servidão e a desigualdade abolidas no plano político. Esta revolução pela metade promove a união das antigas paixões antiburguesas, herdadas da Revolução Francesa, com as novas, surgidas do não cumprimento das promessas efetuadas. Esta confluência forma o ódio à burguesia e à democracia por ela representada. Este ódio perpassa toda a história da Europa — mas não dos Estados Unidos — desde o século XVIII, e é sobre os escombros da Primeira

12 Este é um dos temas presentes na conversa mantida entre Arendt e Eric Voegelin por meio de resenhas e cartas. Cf. Voegelin, "The Origins of Totalitarianism"; Arendt, "A Reply to Eric Voegelin" in Essays in Understanding; Baher, "Debating Totalitarianism: An Exchange of Letters Between Hannah Arendt and Eric Voegelin"; Eccel, Entre a política e a metafísica: filosofia política em Hannah Arendt e Eric Voegelin.

${ }^{13} \mathrm{Cf}$. Furet, Le passé d'une illusion, p.502

${ }^{14}$ Furet, Le passé d'une illusion, p.20 
Guerra que ele consegue se articular em uma força política capaz de propor algo contrário à democracia vigente. É desta articulação que surgem Lenin, Mussolini e Hitler.

Graças à ideia de ódio à burguesia, Furet se mostra capaz de fazer um movimento duplo. Por um lado, mostra a convivência íntima entre a burguesia, salvaguarda da democracia, e o ódio que a ela mesma se dirige e que contém germes do totalitarismo. Por outro, recoloca a oposição entre totalitarismo e democracia, que já conta com longa história no interior do liberalismo. ${ }^{15} \mathrm{O}$ resultado é um quadro em que, na história do século $\mathrm{XX}$, os regimes construídos pelo ódio à burguesia são totalitários e aqueles que foram ameaçados ou destruídos por este mesmo ódio são democráticos. Nascidos de diferentes ligações estabelecidas com a mesma burguesia, totalitarismo e democracia são apresentados em uma relação de oposição, resultando em sistemas que se excluem mutuamente. Assim pensados, totalitarismo e democracia aparecem como formas últimas, como sistemas opostos e limítrofes além dos quais não há outros. Neste esquema, as linhas de continuidade entre uma e outra são interrompidas, pois o ódio à burguesia destrói e não conserva o que esta realiza.

Decorre disto o pouco interesse em olhar seriamente para as duas primeiras partes do livro de Arendt, onde ela mostra que o evento totalitário é composto por vários elementos estreitamente vinculados à ação da burguesia ao longo da história europeia, como a corrida imperialista ou o desenvolvimento das relações financeiras entre os judeus e o Estado. Entre os primeiros leitores de Arendt, há uma fixação sobre a descrição do sistema totalitário e uma resistência a olhar para as origens do totalitarismo, capazes de apresentar a burguesia e a democracia liberal como participantes da catástrofe. Não como as únicas participantes, tampouco como causas, mas como elementos que cristalizaram no evento totalitário. Tal constatação dificultaria o estabelecimento da oposição entre totalitarismo e democracia e exigiria questionamentos para os quais a direita tem menos disposição do que Arendt. Deste ponto de vista, o único interesse possível na investigação da democracia é a eventual descoberta da formação de ódio contra ela, ou seja, daquilo que a nega. Esta posição confere à democracia burguesa o status de salvaguarda contra a barbárie, do que decorre seu caráter inatacável; qualquer esforço de alteração do sistema que nos protege contra o totalitarismo aparece como suspeito, mesmo que seja para propor outra forma de democracia.

O fato de Furet operar no interior desta estreita baliza não impede que ele se mostre

${ }^{15}$ Cf. a brilhante analise do neoliberalismo feita por Michel Foucault no curso dedicado ao Nascimento da biopolítica, em especial a aula do dia 14 de fevereiro de 1979; Cf. tb. a atualização desta análise feita por Christian Laval e Pierre Dardot em $A$ nova razão do mundo: ensaio sobre a sociedade neoliberal. 
um historiador judicioso e reconheça a fragilidade da democracia burguesa diante da ascensão do ódio à burguesia, ou o apoio que os movimentos fascistas tiveram de amplos setores da burguesia — daí a afirmação de que o ódio à burguesia é ódio contra si mesmo. ${ }^{16}$ Limitado, entretanto, por esta oposição entre totalitarismo e democracia, Furet se vê forçado a escolher um dos lados e opta, evidentemente, pela democracia. Entretanto, o tom triste com que termina seu livro, lamentando "o escândalo do futuro fechado", é bastante eloquente. Ele revela a redução do horizonte de possibilidades políticas decorrente de oposição entre totalitarismo e democracia. "A ideia de uma outra sociedade se tornou quase impossível de ser pensada; ninguém, aliás, lança sobre o tema sequer o esboço de um conceito novo no mundo de hoje. Aqui estamos nós, condenados a viver no mundo em que vivemos." ${ }^{17}$ Furet parece considerar o totalitarismo como um problema superado, mas, longe de celebrar a "vitória da democracia" ou o "fim da história", apresenta-nos o estado atual das coisas de modo resignado, mais movido pela recusa ao totalitarismo do que pelas promessas da democracia.

Diante deste triste binômio, não é surpreendente que alguém opte pela postura exatamente inversa à de Furet. Tanto a tenacidade da oposição entre totalitarismo e democracia quanto o estreitamento dos horizontes políticos por ela imposto são visíveis na crítica de Slavoj Žižek à noção de totalitarismo. Escrevendo em 2001, ele se lança à denúncia do totalitarismo como um conceito "tapa-buraco", um "antioxidante ideológico" que "nos desobriga de pensar, ou nos impede ativamente de pensar." Para ele, "a academia que hoje se declara 'radical' é permeada de regras e proibições tácitas (...). Uma dessas regras diz respeito à onipresença inquestionada da necessidade de 'contextualizar' ou 'situar' uma posição (...). Outra dessas regras foi a elevação de Hannah Arendt a autoridade intocável, ou seja, a referência." Dando um passo além, ele afirma ainda que a "exaltação de Arendt talvez seja o sinal mais claro da derrota teórica da esquerda - o fato de a esquerda ter aceitado as coordenadas básicas da democracia liberal ('democracia' versus 'totalitarismo' etc.) e agora está tentando redefinir sua (o)posição dentro deste espaço." 18

De fato, se nos mantivermos no interior do quadro estabelecido pela Guerra Fria, Žižek está coberto de razão. O conceito de totalitarismo, ao qual Arendt é imediatamente associada, foi decisivo em uma estratégia ideológica destinada ao "controle dos radicais

\footnotetext{
16 "Nascido da democracia e crescido em seu seio, o ódio ao burguês só aparentemente é ódio contra o outro. Em seu centro, ele é ódio de si." (Furet, Le passé d'une illusion, p.29)

${ }^{17}$ Furet, Le passé d'une illusion, p.572

18 Žižek, Alguém disse totalitarismo?, p.7-8 — grifos no original.
} 
livres" e ao fechamento das opções políticas. Ele serviu e ainda serve para desarmar qualquer questionamento da democracia vigente, que aparece como a única possibilidade realista e contra a qual só se pode oferecer ilusões que inadvertidamente nos conduzem ao totalitarismo. Deste ponto de vista, Arendt não estaria muito distante, por exemplo, daqueles autores que se lançaram à reformulação do liberalismo, para os quais a melhor maneira de salvaguardar a preciosa democracia atual é limitando a presença do Estado na vida das pessoas - afinal de contas, o totalitarismo não acontece quando o Estado absorve inteiramente a sociedade? Os campos de concentração não realizaram o domínio total dos indivíduos pelo Estado? A luta contra o totalitarismo se faria, portanto, por meio da ampliação dos espaços de livre competição econômica entre os indivíduos, espaços em que têm predomínio sobre as determinações estatais. Concentrados em seus afazeres pessoais, os indivíduos inadvertidamente ampliariam o espaço de liberdade e diminuiriam o espaço de opressão estatal, afastando os riscos de um governo totalitário. No interior deste quadro, a única alternativa à resignação "realista" de Furet "é quebrar sem temor esses tabus liberais. $E$ dai se formos acusados de 'antidemocráticos', 'totalitários'..."19

Do ponto de vista da leitura que se faz da obra de Hannah Arendt, Žižek está tão equivocado quanto Furet e a esquerda americana presente no colóquio em Harvard. Todos eles escamoteiam a obra arendtiana e não vão muito além da terceira parte de Origens do totalitarismo, fixando-se na descrição dos regimes de Hitler e Stalin, sem considerar devidamente as duas primeiras partes do livro, para não falar do restante da obra da autora. No fundo, recusam-se a aceitar seriamente a transformação do termo "totalitarismo" em um conceito de grande alcance realizada por Arendt e por outros autores a partir de meados dos anos 1950; permanecem ainda excessivamente tributários da formulação feita ainda nos anos 1930 e absorvida pela disputa ideológica ao longo da Guerra Fria. Sem considerar o salto qualitativo realizado a partir dos anos 1950, totalitarismo se reduz a uma maneira de descrever regimes que se opõem ao liberalismo, seja pela esquerda, seja pela direita. Um dos objetivos da presente tese é mostrar que o conceito de totalitarismo vai muito além disto. ${ }^{20}$

\footnotetext{
19 Žižek, Alguém disse totalitarismo?, p.8.
}

${ }^{20}$ Analisando Origens do totalitarismo em sua reinterpretação do pensamento arendtiano, Margaret Canovan afirma: Dado o desequilíbrio no livro efetivo (actual), entretanto, é fácil supor que, se o que interessa a alguém é a teoria arendtiana do totalitarismo, deve então se concentrar na última parte do livro sem prestar muita atenção para o restante ou para a difícil questão a respeito da união destas partes. Mas qualquer pessoa tentada a tomar este atalho deve parar de considerar como foi possível que ela tenha realizado esta mudança 
O problema desta oposição entre totalitarismo e democracia não está nos termos em si, mas na extensão da "evidência" que caracterizou o surgimento da oposição entre eles nos anos 1930 e os vinculou a cada um dos polos da Guerra Fria. Considerando os próprios termos, a oposição pode resultar em pensamento potente, como prova, por exemplo, a obra de Claude Lefort. Pensador desde muito cedo preocupado com os desdobramentos do stalinismo e pouco afeito à ordem ocidental, Lefort pensa o totalitarismo como o oposto da democracia sem identificar, no entanto, a democracia ao sistema que se opôs à URSS durante o século XX. A obra lefortiana se desenvolve a partir do presente histórico em que é elaborada, mas supera este momento formulando uma teoria política no interior da qual o lugar do poder é um elemento de particular importância. No que se refere à oposição entre totalitarismo e democracia, é este lugar que oferece o critério de distinção, pois um regime é dito democrático quando o lugar do poder é essencialmente vazio, sendo ocupado rotativamente, ao passo que a ameaça totalitária está na pretensão de preencher definitivamente este lugar. Deste ponto de vista, é evidente que o regime de Stálin seja totalitário, mas não é evidente que seus opositores sejam democráticos.

A mutação política que caracteriza a sociedade totalitária é concebida por Lefort como uma condensação de três esferas distintas: a do poder, a da lei e a do saber. O poder se apossa do conhecimento dos fins últimos da sociedade, de suas normas de funcionamento e também dos órgãos que anunciam tudo isto, formulando por fim a representação do povoUM, no interior do qual as divisões sociais são mascaradas. Se tomarmos a título de exemplo o discurso e a ação de governantes afeitos às políticas de austeridade fiscal, notamos ameaças totalitárias no interior de "insuspeitos" governos democráticos. De modo característico, estes governos são eleitos com base em certo discurso econômico pretensamente técnico ou mesmo científico, diante do qual a única postura razoável é a aquiescência. Este discurso se funda no conhecimento de certa essência comum a todos homens que se expressa no interesse econômico e possibilita a concepção dos cidadãos exclusivamente como homo oeconomicus. Esta unificação de todos por meio de uma suposta essência presente em cada um resulta na atomização de indivíduos e na homogeneização do social permitindo a identificação, por parte dos portadores do conhecimento, de "leis naturais" do comportamento social e, ato

tardia que a levou da escrita de um livro centrado no nazismo para a produção de uma teoria do totalitarismo no sentido mais amplo. A resposta, evidentemente, está em que, embora a experiência do nazismo esteja na raiz de suas reflexões, ela escrevia desde o início sobre eventos e experiências mais amplas." Canovan, Hannah Arendt: A Reinterpretation of Her Political Thought, p.19 - grifo nosso. 
contínuo, a alteração na legislação vigente a partir, não da deliberação dos cidadãos, mas de cálculos técnicos pretensamente válidos para administrar de modo ótimo qualquer que seja a circunstância. Governantes são eleitos rotativamente, mas seu poder é restrito por determinações deste tipo de lei, contra as quais ele não pode ir. Duas conhecidas afirmações de Margareth Thatcher ilustram bem este esforço de preencher o lugar do poder com uma tecnocracia econômica. Com There is no alternative!, a dama de ferro deixava clara a limitação do poder às imposições do dito mercado livre; com There is no such thing as society!, indicava que o indivíduo, concebido exclusivamente como agente econômico, é o substrato sobre o qual todo governo deve elaborar seu programa. Em termos lefortianos, um governo que assim reduz o espaço de poder é antidemocrático e, consequentemente, traz consigo ameaças totalitárias; neste exemplo concreto, as ameaças estão ali mesmo onde se pretende erigir salvaguardas contra o totalitarismo por meio do mercado, "seu oposto".

Para Lefort, a principal marca da democracia é que é uma formação histórica, portanto, indeterminada e aberta ao futuro, de tal maneira que um dos caminhos possíveis é justamente o totalitarismo. Em lugar da oposição abstrata entre totalitarismo e democracia, Lefort procura na própria indeterminação constitutiva da democracia uma possibilidade totalitária. O ponto importante aqui não está tanto em decidir se a vida das pessoas na Inglaterra dos anos 1980 era melhor ou pior que sob Stálin nos anos 1940, mas em resistir à tentação de opor inteiramente duas formas de governo e, consequentemente, deixar de notar elementos mais profundos que sustentam a continuidade entre ambos. Contrariamente a este esforço totalitário de preencher o lugar do poder pela representação do povo-UM, a democracia é capaz de acolher a indeterminação constitutiva da sociedade, representar sua pluralidade e institucionalizar os conflitos dela decorrentes - uma patente dificuldade do "mundo livre". 21

Além de ir contra a oposição simples entre totalitarismo e democracia, esta possibilidade de pensar a ameaça totalitária no interior dos regimes ditos democráticos interrompe a euforia de quem acreditou estar vivendo o fim da história, pois impede a ideia de que o totalitarismo é uma ameaça superada, localizada em algum lugar marginal ou fora do sistema, um ponto ainda escuro, mas sobre o qual as luzes da "ordem ocidental" inexoravelmente incidirão mais cedo ou mais tarde. Esta outra maneira de conceber a oposição foi aqui exemplificada por Lefort, mas este nunca escondeu seu débito a Hannah

${ }^{21}$ A obra de Lefort se espalha por artigos organizados em diversos volumes, dentre os quais destacamos, um tanto arbitrariamente, "La question de la démocratie" e "La logique 
Arendt, que está entre os autores que lhe ofereceram a possibilidade de pensar o totalitarismo em um outro nível. ${ }^{22}$ Esta possibilidade se associa intimamente à recusa de se balizar pela formulação de direita e esquerda vigente na Guerra Fria e à preocupação em detectar o que resta do totalitarismo depois do fim dos regimes totalitários. Esta preocupação com a permanência da ameaça totalitária é um dos eixos de sustentação da obra arendtiana e, à diferença da maioria de seus leitores, foi imediatamente percebida pelos estudiosos de sua obra.

A maior parte dos estudos que têm a obra de Arendt como objeto costuma passar ao largo desta oposição, pelo menos em sua versão mais ligeira. Já no pioneiro The Political Thought of Hannah Arendt, publicado por Margaret Canovan em 1974, nota-se que a oposição totalitarismo versus democracia não tem lugar. Neste, que é talvez o primeiro livro inteiramente dedicado à obra da autora, o totalitarismo aparece como a questão central do pensamento de Arendt, a partir da qual o restante de sua obra se desenvolve:

Como veremos mais a frente, muito de seu pensamento político se ocupa de questões
que surgem em sua compreensão do totalitarismo: ocupa-se especialmente da
liberdade, compreendida como o poder de indivíduos agirem em conjunto e iniciarem
algo; do conflito entre realidade e ficção e da dependência que uma comunidade
estável tem de um senso de realidade, de um senso comum (commom sense); e do
esforço humano de alcançar a dominação total, de não aceitar nada como dado,
exemplificado tanto pelo totalitarismo quanto pela corrida espacial. Estes parecem
ser para ela os problemas políticos de nosso tempo.

A ideia de que o totalitarismo é o tema fundamental do pensamento arendtiano é aqui expressa claramente, mas deve-se notar que o termo democracia não aparece nesta pequena lista composta dos desdobramentos da questão do totalitarismo e dos "problemas políticos de nosso tempo". Canovan fala um pouco mais extensamente em democracia quando se lança à explicação da preferência de Arendt por grassroots democracy, democracias de base, mais horizontais, exemplificadas pela Comuna de Paris, pelos soviets e por conselhos de trabalhadores, radicalmente opostas às democracias existentes na "ordem ocidental". ${ }^{24}$

totalitaire" (cf. bibliografia).

${ }^{22}$ Lefort está entre os responsáveis pela introdução do pensamento de Arendt na França (Cf. Mongin, "La réception d'Arendt en France") e sua admiração por ela é declarada em vários textos. Em alguns, apenas en passant, como ao longo de "La logique totalitaire" e no início de "L'image du corps et le totalitarisme"; em outros, o débito é tematizado diretamente dando ocasião também para a elaboração de suas distâncias com relação à autora, como em "Hannah Arendt et la question du politique", "Thinking with and Against Hannah Arendt" e "Loi de mouvement et idéologie selon Hannah Arendt" (cf. bibliografia).

${ }^{23}$ Canovan, The Political Thought of Hannah Arendt, p.26

${ }^{24}$ Cf. Id. p.66-76 
Elizabeth Young-Bruhel, ainda antes de publicar sua notável biografia sobre Arendt - até hoje insuperada, embora tenha sido rivalizada pelos grandes trabalhos de Sylvie Courtine-Denamy e Laure Adler ${ }^{25}$ —, nos lembra que a segunda edição de Origens do totalitarismo, de 1958, é acrescida não apenas do capítulo "Ideologia e terror", mas também de algumas reflexões sobre a Revolução Húngara, de 1956, nas quais a oposição do mundo bipolar se mostra inteiramente inadequada à compreensão do pensamento de Arendt.

O que a Revolução Húngara indicou (suggested) a Hannah Arendt foi que os problemas da época - a ascensão da sociedade de massas, mudanças tecnológicas sem precedentes e o colapso do Estado-nação — podem levar a dois diferentes tipos de forma de governo: totalitarismo ou sistema de conselhos. Ela depositou toda a sua esperança sobre o sistema de conselhos, o que significa que ela depositou toda a sua esperança na capacidade humana de agir, de começar algo novo, de abrir, como ela diz, "um espaço político". ${ }^{26}$

Seria um equívoco atribuir estas leituras de Canovan e Young-Bruhel a uma eventual simpatia pelo polo da esquerda na divisão de então, uma vez que George Kateb $^{27}$ e Celso

25 Sylvie Courtine-Denamy se serviu da ideia arendtiana de "Quem?" e dos exercícios praticados por Arendt em Homens em tempos sombrios para elaborar uma espécie de biografia da própria Hannah Arendt. "Propomo-nos, portanto, a evidenciar certos acontecimentos que tiveram lugar entre o momento em que Hannah Arendt nasceu (1906) e aquele em que morreu (1975), a fim de responder à questão 'quem?' foi ela, a fim de mostrar em quê ela foi 'ao mesmo tempo semelhante e única ou diferente' de cada um dos seus contemporâneos, a fim de esclarecer, de alguma forma, a sua relação com o mundo em que viveu." (Courtine-Denamy, Hannah Arendt, p.12). Laure Adler, por sua vez, oferece um texto mais parecido com uma biografia propriamente. Sua intenção é a de "dar a conhecer melhor Hannah Arendt. (...) Mas estava fora de questão preencher as lacunas, propor uma narrativa sem falhas nem contradições, suprir as ausências com retoques. Apenas desenhar uma trajetória." (ADLER, Nos passos de Hannah Arendt, pp.13-4) A enorme qualidade e importância do trabalho pioneiro de Young-Bruhel tem como efeito colateral certo esquecimento, por parte dos estudiosos, destes dois grandes trabalhos, que mereceriam ser melhor aproveitados entre os estudiosos, ainda que o livro de CourtineDenamy ressinta um tanto por estar desatualizado. Um tratamento mais justo a eles poderia, talvez, trazer contribuições para a compreensão de um traço importante e expressamente enfatizado em ambos, que é a condição feminina de Hannah Arendt. A este respeito, aliás, é também lamentável que os estudiosos concedam um lugar muito reduzido a $O$ gênio feminino, livro em que Julia Kristeva considera Arendt como uma das "mulheres extraordinárias que, por sua vida e sua obra, marcaram a história deste século", dedicandoIhe um belo ensaio. (Kristeva, J - Le génie féminin. 1. Hannah Arendt. Paris: Gallimard. p.12-3). Adriano Correia faz uma avaliação muito menos positiva do trabalho de Adler. Cf. Correia, " A biógrafa Arendt é mal biografada". Cf. tb. Bignotto, "Hannah e sua biógrafa". ${ }^{26}$ Young-Bruhel, "From the Pariah's Point of View", p.14. O texto foi publicado em 1978.

${ }^{27}$ Kateb é professor aposentado da Universidade de Princeton e, em sua página no sítio da Universidade, encontramos a afirmação de que ele é "o mais importante teórico americano do individualismo democrático" e "escreve na tradição de Emerson, Thoureau e Whitman". Seu Hannah Arendt: Politics, Conscience and Evil, de 1984, se tornou referência para uma geração seguinte de leitores, como Seylah Benhabib e Dana Villa, além da própria Canovan, em sua reinterpretação do pensamento de Arendt realizada nos anos 1990. O acesso ao livro de Kateb é hoje difícil e, no curto período de pesquisa de que dispusemos 
Lafer, ${ }^{28}$ acadêmicos declaradamente alinhados ao liberalismo e também pioneiros dos estudos arendtianos, chegam a conclusões parecidas neste ponto. Lafer termina seu artigo escrito por ocasião da morte de Hannah afirmando a centralidade na obra arendtiana do espaço público, da liberdade por ele possibilitada e da crítica à noção de política como mera administração das coisas:

\begin{abstract}
Restaurar, recuperar, resgatar o espaço público que permite, pela liberdade e pela comunicação, o agir conjunto, e com ele a geração de poder, é o grande tema unificador da reflexão de Hannah Arendt. Graças a este agir conjunto surge a política autêntica e, com ela, a dignidade da vida pública, que Hannah Arendt conseguiu iluminar mesmo num mundo como o contemporâneo, que viveu a experiência do totalitarismo e que se debate com o impasse do pensamento contemporâneo, sofre a trivialidade da administração das coisas e se desespera com as conjunturas difíceis. ${ }^{29}$
\end{abstract}

Como necessariamente acontece aos precursores, estes trabalhos de Canovan, Young-

Bruhel e Lafer ressentem do fato de terem sido publicados quando a obra de Arendt ainda estava sendo elaborada e publicada, sem ter sido ainda objeto de estudos extensos. ${ }^{30}$ Mas eles testemunham, por isto mesmo, o fato de que uma leitura atenta da obra de Arendt, mesmo

em Berlim, foi possível consulta-lo rapidamente e descobrir, pela leitura de seu prefácio, que, para o autor, a crítica arendtiana implícita e aberta a certos aspectos fundamentais da cultura da democracia individualista é desafiadora e mesmo ameaçadora. Ele não pretende fazer, em seu comentário ansioso (anxious), uma síntese impossível ou uma reconciliação, mas se propõe a fazer a obra de Arendt produzir um auxílio (assistance) para a teoria da democracia moderna.

Em um artigo anterior a seu livro, ele também recusa a oposição simples entre totalitarismo e democracia na obra de Arendt: "Afirmemos desde o início que, considerado do ponto de vista da filosofia, o tema da ação política é muito difícil. Seria tolice minha afirmar que consegui compreender tudo o que Arendt escreveu a este respeito. (...) O projeto de Arendt (...) é fazer o que jamais foi feito até então: fornecer uma descrição filosófica do significado da ação. O material básico sobre o qual Arendt, a filósofa, trabalhará é a literatura não filosófica da Grécia e de Roma. Arendt resgatará seu 'tesouro'. Sua ambição é enorme." (Kateb, "Freedom and Worldliness in the Thought of Hannah Arendt", p.147; Cf. tb. Kateb, "Arendt and Individualism"; o sítio da universidade de Princeton foi acessado em 16/11/2017: http://www.princeton.edu/politics/people/display_person.xml?netid=kateb )

${ }^{28}$ Lafer foi aluno de Arendt e responsável pela introdução de sua obra no Brasil. Ele relembra a experiência junto à grande pensadora em pelo menos dois textos: "Introdução de 1979" e "Reflexões de um antigo aluno de Hannah Arendt sobre o conteúdo, a recepção e o legado de sua obra, no 25 aniversário de sua morte". Ambos se encontram em Hannah Arendt: pensamento, persuasão e poder (Cf. bibliografia). A filiação de Lafer à tradição liberal é expressamente declarada, por exemplo, na "Introdução" de seus Ensaios liberais (São Paulo: Siciliano, 1991).

${ }^{29}$ Lafer, Hannah Arendt: pensamento, persuasão e poder, p.35-6

30 Todos continuaram seus trabalhos sobre Arendt e, dentre as várias contribuições importantes, destacam-se alguns livros: de CANOVAN, Hannah Arendt: A Reinterpretation of Her Political Thought; de Young-Bruhel, a biografia clássica For The Love of the World; de LAFER, A reconstrução os direitos humanos: um diálogo com o pensamento de Hannah Arendt. (Cf. Bibliografia) Seyla Benhabib oferece uma extensa lista dos primeiros trabalhos dedicados à obra de Arendt na primeira nota da introdução de seu The Reluctant Modernism of Hannah Arendt. 
que não apoiada em bibliografia secundária extensa, mesmo que feita do ponto de vista liberal, nos leva para longe da oposição totalitarismo versus democracia posta pela "ordem ocidental".

O presente trabalho partilha desta recusa da oposição ligeira entre totalitarismo e democracia. Uma das ideias que o norteiam é a de que esta associação direta entre o nome de Hannah Arendt e o conceito de totalitarismo é justa, mas não pelas razões comumente evocadas. O primeiro grande livro da autora se dedica exclusivamente a uma teoria do totalitarismo que se transformou em referência incontornável, tornando natural a associação à primeira vista. Ao se dedicar ao restante do corpus arendtiano, no entanto, o leitor não deixará de notar que esta teoria dá a impressão de desaparecer do pensamento da autora. No livro imediatamente posterior, A condição humana, o termo se apresenta uma única vez. Nos dois subsequentes, Entre passado e futuro e Sobre a revolução, o totalitarismo aparece pouco e sem grande centralidade na argumentação. O leitor de Eichmann em Jerusalém descobre relativamente pouco a respeito do totalitarismo, ainda que nele Arendt volte diretamente ao tema do nazismo e a acontecimentos fundamentais do regime de Hitler. Em A vida do espírito, seu último (e inacabado) livro, não há reflexões a respeito de regimes de governo e não há nenhuma referência direta a Hitler ou Stalin.

Este aparente recuo do interesse de Arendt pelo problema do totalitarismo ao longo de sua trajetória parece corroborar a escolha de ler apenas a terceira parte de Origens do totalitarismo a fim conhecer o que de mais significativo a autora tem a oferecer. Um olhar atento, contudo, revela que, embora o termo "totalitarismo" tenha perdido a centralidade e o tema pareça ter desaparecido, a questão levantada pelo evento totalitário permanece no centro do pensamento ali expresso. Em A vida do espírito, o tema do mal e da possibilidade de uma ética no mundo contemporâneo constituem eixos centrais do livro. Estas reflexões representam um esforço para responder à perplexidade causada por Eichmann e que levou Arendt a substituir a noção do "mal radical", decisiva na teoria do totalitarismo, por "banalidade do mal". Em Sobre a revolução, a noção de fundação, de início de um corpo político ganha importância em contraste com esforço totalitário de acabar com qualquer iniciativa de quem vive sob seu domínio. Em Entre passado e futuro e em A condição humana, vários dos elementos constitutivos do totalitarismo e presentes em nosso mundo são analisados e discutidos extensamente, mas em outro nível. A tese que o leitor tem em mãos pretende expor alguns destes elementos, tendo sempre em mente que o totalitarismo não vai 
"desaparecer com a morte de Stalin assim como não desapareceu com a queda da Alemanha nazista. Pode até mesmo ser que as verdadeiras dificuldades (predicaments) de nosso tempo assumam sua autêntica forma - embora não necessariamente a mais cruel — apenas quando o totalitarismo tiver se tornado uma coisa do passado." ${ }^{31}$

Este olhar mais atento nos leva a reconhecer, portanto, que a teoria arendtiana do totalitarismo se desdobra ao longo de toda a obra da autora revelando aspectos diversos da novidade essencial do século passado; ela não se resume à descrição dos regimes de Hitler e Stalin, mas pretende vincular estes regimes ao mundo em que vivemos, ao que estamos fazendo. O objetivo da presente tese é mostrar no detalhe o primeiro passo deste desdobramento da questão do totalitarismo. No interior da obra arendtiana, isto equivale à análise da passagem de Origens do totalitarismo a A condição humana; ou, em outros termos, na apresentação do conceito de ação como o oposto do totalitarismo.

${ }^{31}$ Arendt, The Origins of Totalitarianism, p.460. 


\section{Capítulo 1 - A questão do totalitarismo}

Em 1972, a Sociedade de Toronto para o Estudo do Pensamento Social e Político realizou um evento em homenagem a Hannah Arendt ao qual ela mesma compareceu e em que debateu com os presentes. Quando questionada sobre sua posição frente ao capitalismo e ao socialismo, Arendt conduziu a resposta para sua posição no espectro teórico político e afirmou peremptoriamente, como de costume, com: I somehow don't fit! ${ }^{l}$ Esta declaração de estrangeirice foi feita no que se refere à posição política, mas podemos extrapola-la para um outro campo, que é o da disciplina ou área do conhecimento a que Arendt pertence. Afinal, a autora de $A$ vida do espírito, uma profunda reflexão a respeito das vita contemplativa, não é uma filósofa? Ou seria uma historiadora, já que ofereceu também uma acurada descrição da sociedade europeia do início do século XX em Origens do totalitarismo? Suas reflexões sobre as instituições políticas na terceira parte de Origens do totalitarismo e em Sobre a revolução não fazem de Arendt uma eminente cientista política? E o leitor de Eichmann em Jerusalém não está diante de uma longa reportagem?

O inquietante fato de podermos responder plausivelmente "sim" a todas estas questões se deve, em última instância, às dificuldades da própria noção de "área do saber", muito naturalizada nos tempos que correm, mas composta por alta dose de artificialidade. Arendt, aliás, não é a única a colocar este tipo de dificuldades para seus leitores: Adorno é tratado como filósofo, sociólogo ou mesmo crítico literário e musical; existe o Marx filósofo, o Marx economista, o Marx sociólogo; Newton foi matemático e filósofo; no Brasil, Montaigne é muito estudado em departamentos de filosofia, ao passo que na França, nos de literatura. ${ }^{2}$

\footnotetext{
${ }_{1}^{1}$ Arendt, "On Hannah Arendt" in. Hannah Arendt: The Recovery of the Public World, p.336. A revista Inquietude publicou uma tradução desta entrevista e disponibilizou em sua página na internet, resolvendo o problema do acesso difícil a ela. ("Sobre Hannah Arendt" in. Inquietude. Goiânia: vol. 1, n² 2, ago/dez - 2010, pp.123-62)

2 Esta variação de "disciplinas" gera contra Arendt críticas também quanto à qualidade do trabalho propriamente. Uma das críticas mais comuns, mesmo entre seus admiradores, é a de que as referências à história são ruins, distorcidas, excessivamente seletivas etc. Newton Bignotto, por exemplo, demonstra grande simpatia pela autora e ainda assim afirma, a respeito de Sobre a revolução, que "dificilmente podemos tomar as análises de Arendt a respeito da Revolução francesa como uma história de seus principais momentos capaz de nos ajudar na compreensão de seu desenvolvimento complexo e multifacetado." (Bignotto, "Hannah Arendt e a revolução francesa" p.51) Na mesma linha, Hobsbawn, muito menos simpático, afirma que Sobre a revolução pode parecer a certos leitores, uma obra "interessante e proveitosa, mas é improvável que entre eles se incluam estudiosos das revoluções, sejam eles historiadores ou sociólogos." (Hobsbawn, "Hannah Arendt e a
} 
No caso de Arendt, o problema da unidade de sua obra, ou de sua "profissão" nos conduz a sua concepção da atividade do pensar. ${ }^{3}$ Como indica a epígrafe de $A$ vida do espírito, pensar é uma atividade propriamente destrutiva, como o vento, que se faz notar por aquilo que ele faz balançar, não por algum tipo de construção. Neste sentido, Arendt se mostra alinhada a Heidegger (de quem tira a epígrafe de $A$ vida do espírito e a metáfora do vento), a Kant (tal como interpretado por ela) e a Sócrates, que jamais fixou seu pensamento em palavras sobre um papel. No momento em que Platão registrou e eternizou seu mestre, ele adicionou ao pensamento de Sócrates uma rigidez e uma fixidez originalmente ausentes e, ao mesmo tempo, introduziu esta fixidez na tradição da filosofia. A esta mobilidade destruidora intrínseca ao pensar, deve-se somar ainda a exigência que o século XX impôs sobre Arendt no que se refere à tradição de filosofia política. Por razões e caminhos que veremos à frente, Arendt se engaja firmemente na desmontagem desta tradição e na consequente formulação de um novo pensar político, que se abre em várias frentes a fim de cobrir os diversos problemas vinculados à pluralidade dos seres humanos.

O nome propriamente deste novo pensar político é um problema com o qual Arendt se debateu ao longo dos anos, sem jamais chegar a uma solução definitiva. Em sua versão mais conhecida, o problema é abordado na entrevista ao jornalista Günter Gaus, em que a primeira resposta é a seguinte: "Eu devo protestar! Eu não pertenço ao círculo dos filósofos. Minha profissão, se é que se pode chamar assim, é a teoria política (politische Theorie). (...) A expressão 'filosofia política', que eu evito, está extremamente sobrecarregada pela tradição. Quando falo sobre estas coisas, academicamente ou não, sempre menciono a existência de uma tensão vital entre filosofia e política. (...) 'Eu não quero participar desta hostilidade', é exatamente isto! Eu quero olhar para a política, por assim dizer, com olhos livres das nuvens da filosofia." ${ }^{4}$ No entanto, esta firmeza na recusa em participar da filosofia política não se repete na afirmação daquilo que ela efetivamente faz. Aqui, a profissão de Arendt, "se é que se pode chamar assim", é a teoria política, no entanto, dez anos antes, precisamente quando elaborava esta questão da tensão entre a filosofia e a política, ela afirmou praticar "ciência política" (political science) e, incidentalmente, até mesmo a própria filosofia política. ${ }^{5}$

revolução", p.208).

${ }^{3}$ Seguimos aqui Courtine-Denamy, Hannah Arendt, pp.123-55.

${ }^{4}$ Arendt, "What Remains? The Language Remains: A Conversation with Günter Gaus" in. Essays in Understanding, pp.1-2 - grifos nossos.

${ }^{5}$ As ocorrências são várias, mas com pesos distintos. Talvez o momento mais significativo seja "Concern with Politics in Recent European Philosophical Thought", em cujo início Arendt fala em "nós, os cientistas políticos" e em cujo fim fala de uma "autêntica filosofia 
De fato, a recusa é justificada em larga medida, uma vez que Arendt é bastante bem sucedida em seu desejo de "olhar para a política com os olhos livres de filosofia", como veremos à frente ao tratar do esforço decidido de desmontar a tradição, da recusa em apresentar uma definição do ser humano, do cuidado de não tratar a política como um obscuro interior de caverna (Platão) ou como um hospício (Pascal). Por outro lado, no entanto, é difícil não perceber já à primeira leitura a importância de uma série de categorias e procedimentos estritamente filosóficos mobilizados intensamente por esta autora que apresenta uma crítica ao totalitarismo por meio de uma discussão sobre a condição humana, o tempo, o espaço, a liberdade. Além disto, é patente que seu pensamento se apoia sobre um acerto de contas com Platão e Aristóteles, que seu ponto de partida para escrever sobre a condição humana é a obra de Marx, que seu diálogo com o existencialismo é importante e se fundamenta em um recurso a Descartes, Kant e Schelling.

O tema é nuançado e não será resolvido aqui. No entanto, uma vez que a interpretação de A condição humana apresentada nesta tese reforça os aspectos mais, digamos, filosóficos ai presentes, faz-se necessário tomar algumas posições gerais. Como pretendemos mostrar ao longo do trabalho, o problema todo se deve fundamentalmente às obrigações impostas pela ruptura do fio da tradição, que exigiu uma completa desmontagem de elementos tradicionais da filosofia política e, ato contínuo, a formulação de um pensar político livre destes elementos. Esta tarefa de elaboração de um novo pensar anima toda a obra de Arendt e mostraremos nesta tese um momento deste longo esforço, mais especificamente o passo dado entre Origens do totalitarismo e A condição humana. Consequentemente, recusamos a existência de cortes profundos entre a "obra política" e a "obra filosófica" de Arendt. É fato que existem registros diferentes ao longo da obra, mas eles são unificados pela questão do totalitarismo, que surge em Origens do totalitarismo e acompanha a autora em vários de seus desdobramentos até $A$ vida do espírito, seu último trabalho. Recusamos também a simplesmente a afirmação de que Arendt não faz filosofia - ainda que esta afirmação venha da própria autora - dado o alcance de seu pensamento, suas referências mais frequentes e os conceitos mobilizados. O que nos parece mais acertado afirmar, embora ainda sem grandes desenvolvimentos, é que há uma outra ideia de filosofia em operação aqui. Uma filosofia que, antes de tudo, pretende desfazer certos arranjos fundamentais que formaram a tradição filosófica, em especial a superioridade da vita contemplativa sobre a vita activa, responsável

política". Cf. Arendt, "Concern with Politics...", p.428 e p.445. Além deste momento, merecem destaques as ocorrências de "ciência política" em "Understanding and Politics (the 
pela hostilidade da filosofia contra a política. Esta filosofia parece se fundar, ou melhor, se organizar na relação tensa entre os fenômenos e o pensar, tomado aqui em seu aspecto desestabilizante a que nos referimos acima. Parece decorrer desta filosofia a opção por uma descrição precisa dos diferentes tempos e espaços em que os fenômenos se dão e é pela via das diferentes temporalidades das atividades humanas que desenvolveremos a presente tese.

A questão da "classificação" de Arendt apareceu para o público pela primeira vez de modo evidente com o surgimento de A condição humana, livro imediatamente seguinte a Origens do totalitarismo e que apareceu como se fosse seu segundo livro. ${ }^{6}$ Aqui a questão aparece com o evidente salto realizado pela autora, perceptível já nos próprios temas abordados. Se no primeiro encontramos discussões a respeito de acontecimentos concretos

Difficulties of Understansing)" p.320 ss.

${ }^{6}$ Não era o segundo, mas o terceiro livro, posto que ela publicou sua tese de doutorado, $O$ conceito de amor em Agostinho, em 1929, o que também coloca problemas quanto à unidade do corpus arendtiano. Estreitamente vinculado à formação universitária de Arendt, realizada entre a teologia e a filosofia, o livro traz muito pouco dos temas políticos que confeririam notoriedade a sua autora décadas à frente. A mudança se deve, evidentemente, às experiências pelas quais passou nas duas décadas que separam sua tese e Origens do totalitarismo, mas isto não impediu Julia Kristeva de encontrar na tese "o programa de uma obra futura já traçado", ou Ronald Beiner de afirmar que ela contém a "estrutura fundamental das preocupações filosóficas" de Arendt. Argumentando na mesma linha, Joanna V. Scott e Judith C. Stark têm razão quando criticam certa "ortodoxia" que conduz os estudiosos a considerar a tese como algo menor e apartado do corpus realmente significativo, uma vez que Agostinho não está apenas no início do percurso arendtiano, mas é também capítulo importante de seu último esforço, $A$ vida do espírito. Isto, para não mencionar a importância capital entre Origens do totalitarismo e A condição humana, como veremos à frente. Eugênia Salles Wagner considera que o conceito de amor é capaz de atravessar outra fenda na obra arendtiana, aberta pelo julgamento de Eichmann - para alguns, o julgamento teria resultado em preocupações éticas que teriam afastado a política de sua obra tardia.

Apesar disto, no entanto, resta ainda a enorme distância entre as discussões da tese e as discussões a respeito do governo de Hitler, da fundação da República Americana, da violência na política e de muitos outros temas que consagraram Arendt como pensadora política do século XX. Neste ponto especificamente, acompanhamos Benhabib (e outros, como Canovan), para quem os temas do "amor" e do "mundo", presentes na tese e em toda a obra, vinculam Arendt muito mais a seus grandes professores, em especial Heidegger, que a Agostinho propriamente. Em sua tese, Arendt lê Agostinho de determinada maneira e é certo que ele o acompanhou ao longo de sua obra; no entanto, os elementos escolhidos em sua leitura de Agostinho e a maneira em que esta leitura se deu parecem ser mais signiticativos para a unidade do corpus arendtiano do que o conteúdo da obra de um dos pais da Igreja católica.

Cf. Kristeva, Le génie féminin. Hannah Arendt, p.61; Beiner, R - "Love and Worldliness: Hannah Arendt's Reading of Saint Augustine" (in: MAY, L / KOHN, J. - Hannah Arendt. Twenty Years Later. Cambridge: MIT, 1996, 269-84); Scott, J. V / Stark, J.C "Rediscovering Hannah Arendt" (in: ARENDT, H - Love and Augustine. The Chicago University Press, 1996, pp.113-215). WAGNER, E. S - Ética e política. Cotia, SP: Ateliê Editorial, 2006; Canovan, Hannah Arendt: A Reinterpretation of Her Political Thought, p.8-9; Benhabib, The Reluctant Modernism of Hannah Arendt, p.32 N.24. 
como os regimes de Hitler e Stalin, as grandes manifestações de massas dos anos 1930, a guerra dos Bôeres, a política imperialista na África, o caso Dreyfus e as relações financeiras entre os judeus e os Estados, o segundo livro se dedica a "abstrações" como o trabalho, a fabricação, a ação, o público e o privado. Esta discrepância evidente se converteu em um tema importante entre os estudiosos e obrigatório nos textos de apresentação ou introdução a A condição humana. ${ }^{7}$

Apesar de os estudos sobre a obra de Arendt terem se iniciado já nos anos 1970, como testemunham o evento em Toronto e o conhecido livro editado por Melvyn Hill, não parece exagerado afirmar que a biografia escrita por Elizabeth Young-Bruehl, publicada em 1982, constitui uma espécie de fundação dos estudos arendtianos. O fato de uma biografia deste quilate ter aparecido apenas sete anos depois da morte de Arendt constitui uma dádiva da fortuna aos estudiosos da obra da autora, não apenas pela qualidade do trabalho, ainda hoje incontornável, mas pelo fato simples de ser uma biografia, ou seja, por ser um trabalho apoiado em documentos, em material ao qual o público não tem acesso normalmente e que é capaz de estabelecer de modo inquestionável certos pontos ou certos percursos. YoungBruhel mostra, por exemplo, que a passagem de Origens do totalitarismo para A condição humana se dá através de certo intrincamento entre o totalitarismo, Marx e a tradição de pensamento filosófico, algo muito difícil de ser percebido apenas pela leitura dos livros, mas evidente e inquestionável depois da informação, sustentada em documentos, de que, pouco depois de publicar Origens do totalitarismo, Arendt elaborou um projeto de pesquisa sobre os "elementos totalitários no marxismo" a fim de preencher uma lacuna séria do livro recém lançado. Young-Bruhel publica trechos deste projeto e estabelece um percurso que se impõe aos estudiosos, variando, evidentemente, em função das interpretações elaboradas, mas sempre composto pela questão do totalitarismo, por Marx e pela tradição. Em nossa leitura, perfaremos este percurso incontornável, mas não sem antes considerar a contribuição a esta questão oferecida por Paul Ricoeur em uma leitura que, deste ponto de vista, é um tanto heterodoxa e, talvez por isso mesmo, particularmente interessante.

Ao lado de Ricoeur, Celso Lafer e Antonia Grunenberg também escapam ao trajeto que vai do totalitarismo à tradição via Marx, mas por razões bastante distintas. Lafer elabora

7 Cf. A introdução à edição americana, feita por Canovan; cf. tb. o posfácio e a apresentação que Celso Lafer e Adriano Correia respectivamente dedicaram às edições brasileiras, bem como o prefácio escrito por Paul Ricoeur para a edição francesa. A edição alemã não traz texto introdutório. 
seu posfácio à edição brasileira de $A$ condição humana ${ }^{8}$ um ano antes do lançamento da biografia de Young-Bruhel, portanto antes de o vínculo entre totalitarismo, Marx e a tradição estar claramente revelado. Ele leva em conta, apesar disto, o artigo que a própria YoungBruhel havia publicado alguns anos antes a respeito da vida e da obra de Arendt, onde a questão é posta, mas sem desenvolvimentos e sem a centralidade que ganharia depois. Dando um passo além, talvez seja possível afirmar que a formulação de Young-Bruhel, provavelmente devido à concisão exigida pela forma escolhida, é capaz de induzir ao erro, uma vez que ela afirma que "[E]m lugar do estudo proposto a respeito dos elementos totalitários no marxismo, ela [Arendt] escreveu os ensaios contidos em Entre passado $e$ futuro e, em seguida, A condição humana, além de planejar outro livro: Introdução na política." 9 Alguns anos mais tarde, a própria Young-Bruhel mostrará, de modo mais extensamente elaborado, que Arendt não escreveu A condição humana e Entre passado $e$ futuro "em lugar do estudo sobre Marx", mas como um desdobramento do estudo sobre Marx, o que é bastante diferente. De todo modo, Lafer aceita a afirmação de Young-Bruehl segundo a qual Arendt se deu conta, examinando a tradição, de que a palavra e a ação eram vistas com obtusidade pelo pensamento ocidental; ele considera, no entanto, a ideia YoungBruhel insuficiente, pois A condição humana seria, além disto, um olhar para o XX e um esforço para compreender as "origens do isolamento e do desenraizamento, sem os quais não se instaura o totalitarismo". ${ }^{10}$ Grunenberg, por sua vez, também realiza um percurso bastante distinto, mas porque está elaborando um tipo de texto distinto do texto de comentador. Como indica o subtítulo de seu livro, ela está apresentando "a história de um amor" e, deste ponto de vista, não considera relevante o papel de Marx optando por converter a questão da tradição em uma crítica aos resultados da era moderna, como a sociedade de massas e a corrida espacial, que ocuparam os dois personagens desta história de amor. ${ }^{11}$

\footnotetext{
${ }^{8}$ Lafer, "A política e a condição humana"

9 Young-Bruhel,"From the Pariah's Point of View: Reflections on Hannah Arendt's Life and Work", p.13.

${ }^{10}$ Lafer, "A política e a condição humana", p.347

11 Cf. Grunenberg, Hannah Arendt et Martin Heidegger: histoire d'un amour, pp.389-94. O livro de Grunenberg parece-nos a realização bem feita daquilo que Elzbieta Ettinger tentara anos antes, mas sem nenhum sucesso. Trata-se de um esforço para compreender as duas pessoas, que pensaram o século XX, viveram, cada um de um lado, a meia noite deste século e não obstante se amaram convictamente até o fim de suas vidas. Tanto o trabalho de Ettinger quanto o de Grunenberg trazem, ao lado dos protagonistas, coadjuvantes relevantes, em especial Elfride Heidegger, Heinrich Blucher e o casal Karl e Gertrude Jaspers, fundamentais para a trama entre Hannah e Martin. Diferentemente de Ettinger, no entanto, Grunenberg não se deixa atrair pelo psicologismo barato e faz um esforço valioso para vincular todas estas pessoas ao tempo e ao lugar em que viveram. Não apenas à
} 
A contribuição de Ricoeur à questão aparece em seu prefácio à edição francesa de $A$ condição humana ${ }^{12}$, escrito em 1983 e declaradamente em débito com a "luminosa e completa" biografia de Young-Bruhel. Ricoeur adota como ponto de partida aquilo que chama de "diferença de registro" entre Origens do totalitarismo, que apresentou Arendt como "pensadora política de primeira ordem", e A condição humana, uma obra de "filosofia fundamental". Este salto impõe ao intérprete a necessidade de apresentar o elo íntimo e inevidente entre os dois livros, o que nos conduz primeiramente à afirmação de que, em Origens do totalitarismo, há uma tentativa de compreender e descrever o que aconteceu e, em A condição humana, há uma tentativa de evitar que volte a acontecer. Se interrompermos aqui a leitura, arriscamo-nos a repetir a oposição "totalitarismo versus democracia", a considerar Origens do totalitarismo como um manual para a identificação de desvios autoritários e A condição humana como um guia para manter a democracia. Mas Ricoeur evita facilmente este equívoco ao chamar a atenção para a maneira pela qual o esforço de evitar o totalitarismo se desdobra em A condição humana, pois, contrariando certa expectativa, este esforço não se desenvolve em uma teoria da democracia, termo praticamente ausente do livro, ${ }^{13}$ mas em uma investigação a respeito das atividades humanas.

Em harmonia com o percurso determinado por Young-Bruhel, a análise de Ricoeur se inicia com o problema do totalitarismo, mas, de modo mais específico, pretende revelar o sentido da escolha aparentemente disparatada de combater o totalitarismo por meio de uma reflexão sobre as atividades humanas; para tanto, recorre à tese formulada por Arendt a partir

Alemanha da década de 1930, como se faz com alguma frequência, mas também à Messkirch do fim do século XIX, à Konigsberg dos anos 1910, à Weimar e à Margburg dos anos 1920, à New York dos anos 1950 a 1970 e à Freiburg do pós-guerra. Ao menos à primeira vista, o livro de Grunenberg não propõe novas compreensões das obras de Arendt e Heidegger, mas ele certamente contribui para a compreensão de Hannah e Martin, pessoas que também foram dois dos maiores pensamentos do século XX.

12 Ricoeur, "Préface" in: Arendt, La condition de l'homme moderne. Há pelo menos dois outros textos seus dedicados à autora, todos curtos e agudíssimos. Os três foram reunidos em Lectures 1: autour du politique. Paris: Seuil, 1991.

${ }_{13}$ Ao longo do livro de mais de trezentas páginas, o termo e seus cognatos não ocorrem dez vezes. Na primeira delas, Arendt compara em nota os ideais marxistas à democracia ateniense (p.131 n.82). Na segunda, para indicar a diferença entre sindicatos e partidos políticos no que se refere às "possibilidades de um governo democrático sob condições modernas" (p.216). No início da seção 31, entre as páginas 220 e 222, o termo ocorre mais algumas vezes e, na primeira delas, em que o termo aparece entre aspas, é possível notar claramente que a preocupação de Arendt se lança para a política, não para a democracia: "Este esforço de substituir o agir pelo fazer é manifesto no conjunto de argumentos contra a 'democracia', que, quanto mais consistentes e melhor elaborados (reasoned) forem, melhor se converterão em argumentos contra o essencial da política." (p.220). A edição alemã do livro, traduzida pela própria Arendt, que inseriu pequenas reformulações ao longo do texto, 
de uma afirmação de David Rousset, segundo a qual, no totalitarismo, "tudo é possível". Esta tese não pretende indicar, como poderia parecer à primeira vista, a existência de um acaso absoluto em que nada é previsível e que devemos esperar absolutamente qualquer coisa vinda da fortuna. Apresentada por Arendt no início de "dominação total", a última parte do capítulo doze da edição definitiva de Origens do totalitarismo, ${ }^{14}$ a tese de que "tudo é possível" pretende apontar para as ilimitadas pretensões do totalitarismo e se vincula estreitamente a certa crença na onipotência humana, que funciona apoiada sobre a fé de que, uma vez que se dispõe da ciência e da técnica necessárias, é possível realizar absolutamente tudo. Esta fé precisa ser verificada e posta em prática, do que decorre a criação de laboratórios para a realização dos experimentos capazes de comprovar a onipotência humana. O campo de concentração aparece aqui como este laboratório exigido pelo totalitarismo e é por isto que, "por improvável que possa parecer, (...) [ele é] a verdadeira instituição central do poder organizacional totalitário." 15

\section{Campos de concentração e política}

Importa notar aqui que a relevância dos campos na teoria arendtiana não decorre exatamente das dores aí infligidas. Massacres de populações nativas ou consideradas hostis são conhecidos desde Roma, foram realizados extensa e intensivamente na América recém descoberta, no Congo belga e em mais uma série de outros lugares em diferentes momentos. Nem mesmo a ideia de concentrar pessoas em um campo é uma novidade do totalitarismo, como a própria Arendt mostrou. ${ }^{16}$ É evidente que a extensão e a intensidade do mal aí realizado importam na reflexão arendtiana, mas o decisivo aqui é a vinculação entre os campos e a forma de governo em que ganham sentido.

A revelação deste sentido exige uma compreensão propriamente política do fenômeno, do que decorre o peso secundário conferido à economia, à psicologia, à sociologia e às demais ciências humanas na teoria arendtiana do totalitarismo. Apesar disto, no entanto, seria impreciso afirmar que os campos são uma instituição política propriamente. Isto porque

inclui o termo também na p.257, mas igualmente sem grandes consequências.

${ }^{14}$ Arendt interveio no texto de seu livro e atualizou sua bibliografia algumas vezes depois da primeira edição, em 1951. A maior alteração talvez tenha sido a inclusão de "Ideologia e terror" em substituição ao capítulo de encerramento da primeira edição. Cf. Young-Bruhel, Hannah Arendt: For the Love of the World, p.278 n.28; Adler, Nos passos de Hannah Arendt, p.355-6.

${ }^{15}$ Arendt, The Origins of Totalitarianism, p. 438.

${ }^{16}$ Cf. Arendt, The Origins of Totalitarianism, capítulo 7, especialmente pp. 191-207. 
a relação entre os campos e a política é de natureza negativa, ou seja, os campos de concentração adquirem um sentido político precisamente porque levam a negação da política às últimas consequências, porque neles estão condensados certos elementos antipolíticos que perpassam a vida humana em vários níveis, de modo que é mais preciso afirmar os campos como instituições essencialmente antipolíticas.

A fim de revelar o sentido antipolítico da instituição central desta forma de governo, Arendt recorre à tipologia dos regimes políticos proposta por Montesquieu com base nas ideias de natureza e princípio de um regime. Como se sabe, Montesquieu reduz os regimes políticos a três tipos: república, monarquia e despotismo. ${ }^{17} \mathrm{Um}$ eventual esforço de considerar o totalitarismo uma forma de república é, por óbvio, inadequado e sequer merece a atenção de Arendt. A comparação com a monarquia e o despotismo, por sua vez, é mais plausível e exige uma elaboração que a autora realiza a fim de recusar a afirmação comum segundo a qual o totalitarismo não é mais que uma tirania moderna. De acordo com Montesquieu, um elemento fundamental para a distinção entre monarquia e despotismo é a relação que ambos mantêm com a lei; ambos são governos de uma só pessoa, mas a monarquia é regida por leis fixadas e de conhecimento público, ao passo que a tirania é governada pelo volúvel arbítrio do tirano. A fim de sustentar a ideia de que estamos diante de uma nova forma de governo, Arendt também recorre ao papel da lei e afirma, sem hesitações, que o totalitarismo é regido por leis, não pela vontade do líder. Esta lei, no entanto, é de espécie diferente e exige uma forma de relacionamento distinto porque pretende ultrapassar a legalidade sustentada pelas leis positivadas e alcançar diretamente a fonte última da legitimidade destas leis. Ao longo da história, a legitimidade das leis dos diferentes regimes quase sempre se apoiou de alguma maneira em uma fonte superior, seja na divindade dos reis, no lúmen naturale, na voz de Deus. Qualquer que fosse, no entanto, a proximidade entre a legalidade e a instância que a legitima, todos os regimes mantiveram alguma diferença entre elas; a fonte da autoridade da lei sempre se manifestou através dos seres humanos, mas sem jamais se identificar com as leis nela baseada, tampouco com sua execução ou, ainda menos, com os seres humanos que vivem sob sua autoridade. Rompendo com todas as formas de governo precedentes, o totalitarismo pretende realizar a Justiça na terra transformando cada ser humano em uma encarnação da grande Lei que em última instância sustenta a legitimidade em que se apoiam as leis positivadas; esta grande Lei era, para Stalin, a Lei da História e, para Hitler, a da Natureza. O totalitarismo é uma nova forma de governo porque,

${ }^{17}$ Montesquieu, O espírito das leis, II, I. 
entre outras coisas, nele não se deve agir no interior da lei, mas ser sua encarnação.

Ainda de acordo com Montesquieu, cada tipo de governo tem suas ações impulsionadas por um princípio: na república, este princípio é a virtude; na monarquia, a honra; no despotismo, o medo. O princípio não é a única paixão ou qualidade presente no corpo político, mas é aquilo que oferece o sentido às ações e os critérios para o juízo. No totalitarismo, esta função do princípio é cumprida pela ideologia, concebida por Arendt de modo bastante literal como a lógica de uma ideia, e composta por três elementos: pretensão à totalidade, forte caráter lógico e distanciamento da realidade. ${ }^{18}$ Isto significa que ela funciona a partir de alguma premissa totalizante, da qual todas as consequências são tiradas independentemente de seus efeitos na realidade. Esta premissa geral era a Lei da História ou da Natureza, que invariavelmente conduz à conclusão de que as "raças incapazes" ou as "classes agonizantes" são estorvo à realização da grande Lei; esta conclusão, por sua vez, conduz inescapavelmente à exigência de superação destes obstáculos. No plano da realidade concreta, esta cadeia de raciocínios conduziu milhões de pessoas organizadamente para a morte e este assombroso dado de realidade pouco efeito teve sobre o movimento e as massas, pois elas estavam bastante protegidas da realidade ao seguir sua lógica suficientemente racional. De acordo com Montesquieu, a natureza do regime republicano é o poder soberano nas mãos do povo ou de parte dele; a natureza da monarquia, o governo de uma só pessoa em acordo com leis; a do despotismo, o governo de uma só pessoa segundo seu arbítrio. Substituindo o termo "natureza" por "essência", Arendt afirma que a essência do totalitarismo está nesta realização da Lei, o que Hitler e Stálin fizeram por meio do terror. ${ }^{19}$

Esta abordagem propriamente política, assentada sobre as ideias de forma, essência e princípio de governo tem a vantagem de explicar algo difícil, que é o caráter antiutilitário dos campos de concentração e de extermínio. Do ponto de vista puramente administrativo e econômico, os campos representavam dispêndio de tempo e dinheiro, de modo que sua existência confunde analistas assentados na ideia do cui bono — ou do follow the money, como é comum dizer hoje - porque estes não conseguem identificar com precisão qual

\footnotetext{
${ }^{18}$ Arendt, The Origins of Totalitarianism, p.470-1.

${ }^{19}$ Há pelo menos um outro momento, conectado a este, em que Montesquieu aparece na obra arendtiana. Ao editar $A$ promessa da política, Jerome Kohn recortou de uma reflexão maior um texto de Arendt sob o título "A revisão da tradição em Montesquieu" (in: Arendt, $A$ promessa da política, pp.110-17). Embora as relações entre Arendt e Montesquieu sejam um tema presente nos estudos arendtianos há já algum tempo, parece faltar ainda algum estudo de grande fôlego ou capaz de se tornar canônico. De qualquer modo, lê-se com proveito Amiel, "Hannah Arendt lectrice de Montesquieu" e Balestra, "Hannah Arendt, leitora de Montesquieu: ensaio sobre o totalitarismo e as revoluções".
} 
interesse econômico levou à construção e manutenção dos campos. Arendt afirma que esta busca não leva longe porque a função dos campos não tem qualquer senso utilitário, não resulta de qualquer interesse, ainda que possa eventualmente favorecer ou criar algum. A função efetiva dos dispendiosos campos de concentração e extermínio no interior do sistema totalitário é a realização do "ideal social que guia a dominação total"20 conduzindo o corpo político e o governo em direção à transformação de cada indivíduo na encarnação da Lei, ainda que isto contrarie a racionalidade administrativa e econômica.

Em seu extenso estudo da economia nazista, Adam Tooze reafirma a percepção de pesquisadores de que há uma contradição entre o enorme problema de falta de mão de obra enfrentado pela economia de guerra alemã e o assassinato deliberado e custoso de homens e mulheres que poderiam suprir esta falta. A partir de 1940, quando as baixas de guerra já atingiam as dezenas de milhares de homens e a economia de guerra demandava um número cada vez maior de trabalhadores - Tooze estima que a necessidade não estava na casa das centenas de milhares, mas na de milhões ${ }^{21}$ — Hitler e o Gauleiter Fritz Sauckel iniciaram um programa de importação forçada de trabalhadores estrangeiros, que atendia às necessidades impostas pela racionalidade econômica e administrativa, mas "estava transversalmente cortado por linhas selvagens de discriminação racial. (...) No que se refere ao problema cardeal da força de trabalho, é difícil evitar a impressão de que o Terceiro Reich encarou uma contradição insolúvel entre sua ideologia racial genocida e os imperativos práticos da produção."22 Ainda segundo Tooze, esta contradição tem mobilizado historiadores desde os anos 1970 forçando-os a pensar em termos de um "acordo" (compromise) entre elementos ideológicos e práticos, em que um ou outro cede de tempos em tempos em função de decisões frontalmente conflitantes, nem sempre tomadas por departamentos diferentes.

No que se refere especificamente aos campos e sua possível importância econômica no interior do sistema totalitário alemão, Nikolaus Wachsmann considera uma simplificação afirmar que os campos representam exclusivamente violência, terror e morte. Embora fossem também isto, uma compreensão adequada deve considerar também os trabalhos forçados que tiveram lugar nos campos e começaram muito antes da importação de mão obra. No início, o trabalho forçado era pensado como forma de castigo ou reabilitação para os prisioneiros, que, ao longo dos anos, passaram a realizar pequenas tarefas, como a construção de estradas ou a

\footnotetext{
${ }^{20}$ Arendt, The Origins of Totalitarianism, p. 438.

${ }^{21}$ Tooze, The Wages of Destruction, p.513ss.
} 
secagem de pântanos. "Em seu nível mais elementar, o trabalho era um princípio organizacional útil para manter os internos ocupados. Além disto, afirmava-se que trabalho produtivo diminuía os custos da detenção." ${ }^{23}$ A partir de certo ponto ainda nos anos 1930, Himmler decidiu que as SS deveriam florescer economicamente e, com o auxílio de Oswald Pohl, passou a organizar os campos de concentração para este fim. Em 1938, encontraram uma função com alguma importância em pedreiras destinadas a fornecer a monumental quantidade de tijolos que os planos de Albert Speer então demandavam. Também aqui, a utilidade econômica era cortada por decisões inteiramente ideológicas, como mostra a decisão de enviar às pedreiras os prisioneiros considerados especialmente "maus", pois acreditava-se que as pedreiras ofereciam os piores trabalhos, e os piores prisioneiros mereciam estar aí. A fábrica de tijolos de Oranienburg foi o maior empreendimento das SS e seu retumbante fracasso revelou a completa incompetência das SS.

\begin{abstract}
A fábrica de tijolos se revelou um desastre gigantesco, fazendo lembrar alguns dos vastos e inúteis projetos de estado tocados pelos soviéticos nos gulags. O momento decisivo veio em maio de 1939, durante o primeiro teste de verdade, com a fábrica já meses atrasada. Oficiais da SS assistiram incrédulos seus sonhos se transformarem em pó, literalmente: os tijolos saídos dos fornos novíssimos se esfarelavam e caiam aos pedaços. Em sua pressa e ignorância, os gerentes da SS cometeram uma série de erros elementares. O pior foi jamais terem se incomodado em verificar se a argila local era adequada para a produção em prensa seca. Não era. A enorme fábrica nova, que custou tantas vidas, jamais produziria um único tijolo utilizável. ${ }^{24}$
\end{abstract}

A reação de Pohl ao fracasso expressa bem a relação entre os nazistas e a racionalidade econômica, pois, em vez de diminuir as ambições ou interromper as atividades, Pohl escondeu de Himmler o quanto pode a extensão do fracasso a fim de não prejudicar sua carreira e ampliou a produção, recorrendo a gerentes mais jovens com conhecimentos mais modernos.

Em 1940, depois do reinício da produção em pequena escala, a usina mal produziu três milhões de tijolos, a maioria dos quais foram necessários no próprio local. Embora a produção tenha aumentado nos anos seguintes, ela jamais chegou perto dos objetivos originais. No entanto, a húbris da SS permaneceu intacta, na medida em que os gerentes da SS teimosamente se agarraram à crença de que era possível realizar qualquer plano desejado, por extravagantes e mortais que fossem. ${ }^{25}$

A exitosa carreira subsequente de Pohl exemplifica o desprezo da racionalidade econômica dentro do sistema nazista tornando difícil conferir centralidade ao aspecto econômico dos campos e afirmar ser esta era a razão pela qual foram criados, ainda que

\footnotetext{
22 Tooze, The Wages of Destruction, p.520.

${ }^{23}$ Wachsmann, $K L$ - A History of Nazi Concentration Camps, p.158

${ }^{24}$ Wachsmann, KL: A History of Nazi Concentration Camps, p.168

${ }^{25}$ Wachsmann, KL: A History of Nazi Concentration Camps, p.168
} 
consideremos a economia do trabalho forçado na Alemanha.

Contradição parecida é perceptível no caso dos gulags. Seu surgimento está vinculado ao primeiro plano quinquenal, momento em que Stálin desapropriou massivamente os proprietários de terra gerando um monumental excedente de presos, que precisavam ser enviados a algum lugar. A saída encontrada foi a organização e conexão de instituições existentes, do que resultaram os primeiros gulags. Apesar de o elogio das novas instituições feito por Máximo Gorki celebrar a "transformação de personalidades criminosas e não sociais em úteis cidadãos da URSS", ${ }^{26}$ documentos mostram que o governo estava pensando em termos de racionalização da mão de obra a ser usada na extração de matéria prima necessária para a realização dos planos quinquenais. Embora o custo em termos de vidas humanas tenha sido inteiramente desproporcional com relação à produtividade, houve certo êxito econômico do plano em geral ao longo de alguns anos. Apesar disto, no entanto, toda a eventual racionalidade econômica precisava passar também pelo crivo da ideologia e, no momento em que elas se tornaram contraditórias, esta venceu aquela.

\begin{abstract}
O desenvolvimento relativamente exitoso da economia do trabalho forçado foi interrompido pelo Grande Terror — repressão em massa de 1937 e 1938. (...) Empresas sob a autoridade da NKDV foram desorganizadas pela prisão de seus diretores, por execuções em massa e pelo acentuado aumento na taxa de mortalidade e exaustão física dos internos. (...) A situação resultante do Grande Terror no Gulag mostrou que os motivos políticos para o Terror se tornaram absolutamente prioritários em relação aos motivos econômicos. (...) Uma parte significativa deles [as vítimas do Terror], como mostra uma lista dos executados, era de homens fisicamente aptos ao trabalho, especialistas altamente qualificados e trabalhadores, constantemente em falta nos projetos da NKDV. O principal objetivo do Grande Terror foi declarado de saída como a aniquilação física dos 'inimigos', em vez de seu uso como mão de obra 'barata'. ${ }^{27}$
\end{abstract}

De toda esta discussão que mobiliza historiadores ainda hoje, o que nos importa aqui é a ideia de que existe esta contradição fundamental no interior dos governos de Hitler e Stalin e, nesta discussão, a teoria arendtiana do totalitarismo se alinha a quem confere importância especial ao fator ideológico. Isto não significa negar a existência de interesses ao encontro dos quais os campos de concentração possam se direcionar, nem negar vínculos entre o nazismo e o capitalismo, sobejamente discutidos na primeira e sobretudo na segunda parte de Origens do totalitarismo; importa notar aqui a recusa de uma análise que confira à economia a última palavra. Se o totalitarismo representa uma novidade, não é a economia que vai nos fazer percebe-la adequadamente, mas sua caracterização como uma nova forma de

\footnotetext{
${ }^{26}$ Applebaum, Gulag, p.86

${ }^{27}$ Khlevnyuk, "The Economy of the OGPU, NKVD, and MVD of the USSR, 1930-1953", pp.48-9
} 
governo que se movimenta na direção da transformar cada indivíduo na encarnação da Lei. Nas sociedades alemã e soviética dos anos 1930, este movimento em direção à Lei avançou por vários âmbitos, dominando um número cada vez maior de pessoas e em âmbitos cada vez mais variados da vida. Apesar da força deste movimento, alguns âmbitos da vida resistiram à dominação e permaneceram como espaços a salvo dela; em Auschwitz e em Kolyma estes espaços não existiam. ${ }^{28}$ Os seres humanos que entram no univers concentrationnaire perdem completamente estes espaços de resistência; morrem juridicamente, moralmente e existencialmente, ${ }^{29}$ terminando por cumprir a Lei diante da qual eles são uma raça inferior ou uma classe decadente. A obediência às forças sobre-humanas da Natureza ou da História que impulsionam e regulam o movimento dos regimes totalitários se efetiva completamente nos campos de concentração e extermínio e é por isto que eles são concebidos "como laboratórios nos quais se verifica a crença fundamental do totalitarismo segundo a qual tudo é possível. Comparados a isto, todos os outros experimentos têm importância secundária (...), embora seja característico que estes laboratórios tenham sido usados para experimentos de todo tipo." 30

\section{Campos de concentração como laboratórios}

Ao usar metáforas, tanto aqui como em outras ocasiões, Arendt pretende "revelar sentidos de que costumeiramente não somos conscientes" ${ }^{31}$ porque com elas é possível reunir e organizar elementos distintos, aparentemente desconexos, mas que acorrem para um mesmo lugar. ${ }^{32}$ Esta metáfora dos campos de concentração e extermínio como laboratórios, bem como o vocabulário científico a ela vinculado - experimento e verificação —, é particularmente importante em nosso contexto precisamente porque com ela é possível articular elementos presentes nos dois registros em que o pensamento de Arendt se apresenta permitindo compreender a "mudança de registro" e, consequentemente, abordar o problema do totalitarismo por um caminho distinto daquele que opõe totalitarismo e democracia.

${ }^{28}$ Uma crítica bastante comum e pertinente à caracterização arendtiana dos campos de concentração afirma que ela não considera as inúmeras diferenças entre os vários campos de concentração na URSS, na Alemanha e ao longo do tempo. De acordo com Enzo Traverso (op. cit. p.63), já Raymond Aron levantou esta crítica.

${ }^{29} \mathrm{Cf}$. Arendt, The Origins of Totalitarianism, p. 446-57.

${ }^{30}$ Arendt, The Origins of Totalitarianism, p.437-8.

${ }^{31}$ Canovan, Hannah Arendt: A Reinterpretation of Her Political Thought, p.97

${ }^{32}$ Arendt discute a relação entre metáforas e o pensar em sua última obra. The Life of the Mind, pp.110-25. Para o papel das metáforas e seus vínculos com a ideia arendtiana de 
Importa notar de saída que a referência à ciência não está direcionada à eficiência dos instrumentos usados. O número extraordinário de vítimas é proporcional às possibilidades oferecidas pelo avanço técnico-científico e não é possível contar esta história sem falar dele. No entanto, Arendt aponta para outro aspecto quando compara os campos a laboratórios. Sua preocupação decorre da consideração de que ali está a realização mais acabada de uma nova forma de governo e que esta forma coincide com a realização historicamente mais acabada de um esforço para "organizar a infinita pluralidade e diferenciação dos seres humanos como se toda a humanidade fosse apenas um indivíduo, [o que] só é possível se cada pessoa puder ser reduzida a uma imutável identidade de reações". ${ }^{33}$

Notemos ainda que a ciência não é causa do totalitarismo. Em primeiro lugar, porque este só ocorreu de fato em duas ocasiões muito precisas, ${ }^{34}$ e a ciência se desenvolveu em muitos lugares, ao longo de muito tempo, de modo que, se ela causasse o totalitarismo, teríamos tido outras experiências em outros lugares e outras épocas. Do ponto de vista mais especificamente arendtiano, a ciência não é causa do totalitarismo porque, na concepção da autora, eventos históricos não têm causas. Como adiantamos acima, Arendt lamentou o uso do termo "origens" no título de seu livro porque ele "sugere, embora vagamente, uma crença na causalidade histórica que eu não tinha quando escrevi o livro e na qual acredito ainda menos atualmente." 35 Arendt é crítica de todas as formas de filosofia da história e, no mesmo movimento, de certas correntes da historiografia moderna que operam por meio da identificação de causas últimas para os acontecimentos. Esta maneira de proceder pressupõe, por um lado, uma fé na capacidade da razão penetrar o movimento do mundo e, por outro, uma redução daquilo que é significativo neste mesmo movimento àquilo que a razão é capaz de apreender. Esta forma de fazer história pretende encontrar padrões subjacentes aos

contar histórias (storytelling), cf. Canovan, Idem, pp.94-8.

${ }^{33}$ Arendt, The Origins of Totalitarianism, p.438.

${ }^{34}$ No prefácio escrito em 1966 para uma nova edição de Origens do totalitarismo, Arendt dedica duas páginas à situação da China. Nelas, ela se diz incapaz de chegar a uma conclusão porque "nosso conhecimento é ainda menos seguro do que era em relação à Rússia nos anos 30" e "as coisas ainda estão em fluxo". Ela afirma ainda que certos traços do totalitarismo são encontráveis em algumas notícias ou discursos, mas que não sabemos como isto reverbera na vida cotidiana, e que certos medos expressos no livro são contrariados. Além disto, o anticomunismo, que tende a "construir uma ficção de nossa parte", atrapalha a análise e, portanto, não é possível ter uma opinião conclusiva sobre o caso chinês. Cf. ARENDT, The Origins of Totalitarianism, pp. xxvi-xxviii

${ }^{35}$ Arendt, "Totalitarianism", p.618. Cf. tb. Voegelin, "The Origins of Totalitarianism"; Arendt, "A Reply to Eric Voegelin" in Essays in Understanding; Baher, "Debating Totalitarianism: An Exchange of Letters Between Hannah Arendt and Eric Voegelin"; Eccel, Entre a política e a metafísica: filosofia política em Hannah Arendt e Eric Voegelin. 
acontecimentos e ser capaz de oferece-los à razão do historiador, que, se obtiver êxito em sua tarefa, pode até mesmo aplicar estes mesmos padrões ao futuro e assim antecipar eventuais acontecimentos. Arendt não nega ao olhar retrospectivo do historiador a capacidade de explicar acontecimentos, mas se recusa a levar longe demais os padrões encontrados por ele, pois considera que "cada evento na história humana revela um panorama inesperado de atos e sofrimentos humanos, além de novas possibilidades que, juntas, transcendem a soma total de todas as intenções desejadas e o significado de todas as origens." ${ }^{36}$ Em todo evento há, portanto, algo de irredutível às intenções e às origens a ele vinculado, e, levando a sério este excesso, considera que o evento traz ao mundo algo novo, algo não previsto pelos agentes, sendo, portanto, essencialmente resistente à noção de "causas históricas". Este excesso, aliás, torna infinita a tarefa dos historiadores, que jamais conseguirão oferecer a totalidade das origens, das determinações ou das "causas" de eventos históricos e sempre serão capazes de conferir novos significados mesmo aos eventos mais antigos e mais estudados. Esta é a razão pela qual Arendt opera apoiada em termos como "elementos", "constelações de elementos" e "cristalizações de elementos" elaborando uma história do totalitarismo preocupada em mostrar, a partir do evento, o sentido dos elementos que convergiram para ele, mas sem apresentar qualquer interesse totalizante ou generalizante; neste sentido, Arendt acompanha Aristóteles, para quem a história lida com o particular, não com o geral. Este modo de proceder é, em última instância, uma exigência da concepção arendtiana da capacidade humana de agir, de iniciar algo novo, como veremos ao longo do presente trabalho. ${ }^{37}$

Assim, tanto a metáfora do campo de concentração como o papel da ciência no totalitarismo - seja nos movimentos, seja em seu funcionamento quando no poder — nos permitem afirmar sem muitas dúvidas que a ciência participa dos elementos que cristalizaram no totalitarismo; por si só, ela não é suficiente para nos levar à catástrofe, embora as tenha permitido de alguma forma. Esta participação não é marginal no evento, uma vez que é decisiva na formação dos campos, que constituem a instituição central do totalitarismo tornando a análise dos elementos totalitários da ciência não apenas autorizada, mas necessária.

A ciência aparece pela primeira vez na passagem em que Arendt se dedica ao papel da

\footnotetext{
${ }^{36}$ Arendt, "Understanding and Politics (the Difficulties of Understanding)", p.320

${ }^{37}$ Há uma apresentação mais extensa da noção de evento em Duarte, O pensamento à sombra da ruptura, pp.36-43; Benhabib afirma haver em Origens do totalitarismo algo como um método baseado em análises de associações semelhante ao praticado por Tocqueville em A democracia na América, cf. Benhabib, The Reluctant Modernism of Hannah Arendt,
} 
propaganda no esforço de convencimento das massas. ${ }^{38}$ Embora os campos propriamente só tenham sido possíveis com o totalitarismo no poder, é possível perceber certo uso da ciência já nos movimentos que conduziram os líderes totalitários ao poder. De modo similar à publicidade comercial (advertisement) de então, frequentemente preocupada em "provar" com "fatos e números" auferidos por um "departamento de pesquisa" que seu produto é o melhor disponível, a propaganda (propaganda) totalitária também se serve de sua "ciência" para provar que existe algo como uma pureza de sangue ou um trem da história com os quais é aconselhável estar de acordo. Assim como a publicidade de sabonete ameaça as moças de terem espinhas e ficarem sem marido caso não usem o produto oferecido, a propaganda totalitária apresenta uma ameaça de perda do trem da história ou irreparável mistura e deterioração do sangue a quem não ouvir seus ensinamentos. Em ambas, a ciência funciona como um substituto (surrogate) do poder e a obsessão por ela desaparece assim que o movimento chega ao poder. ${ }^{39}$

Embora sejam importantes para a compreensão do fenômeno, as similaridades entre publicidade e propaganda encontram limites e, segundo a autora, costumam ser superestimadas. Diferentemente da publicidade, a propaganda totalitária costuma se expressar na forma de uma profecia científica, ou seja, no esforço de prever e enunciar uma longa cadeia de acontecimentos futuros com base nos "conhecimentos" da História ou da Natureza. Além disto, os publicitários não acreditam no que afirmam e podem afirmar o oposto quando for conveniente, ao passo que Hitler e Stalin acreditam piamente em suas doutrinas e seguem de perto sua lógica, a fim de que o futuro prometido se realize mais rapidamente. Ainda fora do poder, as profecias científicas dos movimentos totalitários são anunciadas com o intuito de indicar as intenções políticas mais gerais do movimento, como a construção de uma sociedade sem classes ou o Reich de mil anos. Uma vez no poder, no entanto, esta relação se inverte e as intenções políticas passam a ser enunciadas sob a forma de profecias sustentadas pela "ciência" e pela ideologia.

O exemplo mais famoso é o anúncio feito por Hitler no Reichstag alemão em janeiro
de 1939: "Hoje quero uma vez mais fazer uma profecia: caso os financistas judeus
(...) consigam uma vez mais arrastar os povos para uma guerra mundial, o resultado
será (...) a aniquilação da raça judaica na Europa." Traduzido em linguagem não
totalitária, isto quer dizer: pretendo travar uma guerra e pretendo matar os judeus da
Europa. Stalin, de modo similar, no grande discurso diante do Comitê Central do
Partido Comunista em 1930, quando preparou a liquidação física da direita do partido
e dos desviacionistas da esquerda, descreveu-os como representantes das "classes

pp.69-75.

${ }^{38}$ Arendt, The Origins of Totalitarianism, pp. 340-64

${ }^{39}$ Arendt, The Origins of Totalitarianism, p. 345. 
agonizantes". Esta definição não apenas deu ao argumento sua agudeza específica, mas também anunciou, em estilo totalitário, a destruição física daqueles cuja "agonia" acabara de ser profetizada. Em ambos os casos, o mesmo objetivo foi alcançado: a liquidação foi encaixada em um processo histórico em que o homem apenas faz ou sofre o que, de acordo com leis imutáveis, aconteceria de qualquer modo. ${ }^{40}$

Ambos realizaram suas profecias criando uma guerra, aniquilando os judeus da Europa, fazendo morrer os agonizantes, de modo que as profecias foram transformadas em fatos e estes, por sua vez, foram absorvidos pelo processo "histórico" ou "natural" apreensível apenas pela "ciência" subjacente à ação do líder. Com esta realização dos planos políticos apresentados como o próximo passo da realização da lei da Natureza e da História, a "ciência" totalitária se confirma mostrando-se infalível.

Apesar de identificar a importância da ciência para o totalitarismo e a facilidade com que certa cientificidade conquista as massas, Arendt mantém cuidados no estabelecimento de vínculos entre ciência e totalitarismo. Eric Voegelin aparece aqui ${ }^{41}$ como contraponto, pois ele enxerga uma linha direta que conduz da revolução científica e filosófica do século XVII ao totalitarismo. Segundo ele, o século XVI iniciou a era do "cientificismo" (scientism), um movimento que valoriza o segmento utilitário da existência em detrimento das experiências espirituais. O resultado desta valorização é o "canceroso crescimento" deste segmento e a transformação da ciência em um "ídolo" de que se espera a cura para todos os males da existência. "A ideia de que a estrutura e os problemas da existência humana podem ser substituídos na sociedade histórica pelo segmento utilitário da existência é certamente puro nonsense. (...) $\mathrm{O}$ fato de esta ideia não fazer qualquer sentido, no entanto, não evitou de modo algum que ela se tornasse a inspiração do movimento político mais forte de nossa era." ${ }^{42}$ Para Voegelin, portanto, o totalitarismo é o último estágio deste longo movimento, algo que Arendt jamais afirmaria.

Como vimos acima, os campos de concentração são inteiramente desprovidos de sentido utilitário. Sua criação e manutenção foi, na interpretação de Arendt, dispendiosa e mais atrapalhou do que contribuiu para a administração eficaz ou para o aumento das riquezas do país, ainda que tenha eventualmente caminhado ao encontro de determinado interesse. Seu sentido era inteiramente ideológico e, embora partilhe com a ideologia algo de

\footnotetext{
${ }^{40}$ Arendt, The Origins of Totalitarianism, p. 349.

${ }^{41}$ Ele é citado duas vezes (Cf. Arendt, The Origins of Totalitarianism, p. 346 e 347) com afirmações retiradas do artigo "The Origins of Scientism", publicado pela primeira vez na revista Social Research de dezembro de 1948 e republicado no The Collected Works of Eric Voegelin (Cf. Bibliografia).
} 
sua lógica, o utilitarismo jamais concluiria pela necessidade de construir aquilo que foi a instituição central do totalitarismo. Arendt não nega a importância de certa mentalidade utilitarista e seu papel como elemento do totalitarismo, mas percebe que há um corte entre ela e o caráter inteiramente antiutilitário dos campos e este corte também impacta as pretensões das teorias científicas.

\begin{abstract}
Quaisquer que sejam os defeitos do positivismo, do pragmatismo e do behaviorismo, (...) nenhuma destas teorias assume que é possível 'transformar a natureza do homem' como o totalitarismo tenta efetivamente fazer. Ao contrário, de modo implícito ou explícito, todas elas assumem que a natureza humana é sempre a mesma, que a história é o relato das mudanças de circunstâncias objetivas e das reações humanas a essas mudanças, que o interesse, quando bem compreendido, pode levar a mudanças de circunstâncias, mas não à mudança das reações humanas enquanto tais. ${ }^{43}$
\end{abstract}

Notemos que a questão aqui não é a ciência em geral, mas aquelas que tomam o ser humano por objeto. As ciências não totalitárias consideram algo de essencial e imutável no ser humano e, com base nisto, são capazes de prever e influenciar as reações que os seres humanos podem apresentar diante de determinadas circunstâncias. À diferença de todas elas, a ciência totalitária não almeja apenas conhecer aquilo que é possível prever nos humanos, mas pretende ir mais longe e alterar a natureza do ser humano. Esta aspiração é parte da novidade totalitária e exige um laboratório em que seja possível testar esta hipótese; os campos de concentração e extermínio cumprem esta função e permitem a afirmação de que o univers concentrationnaire é o âmbito em que tudo é possível.

Esta afirmação de que a natureza humana pode ser alterada resultou no momento mais áspero da conhecida resenha que Voegelin dedicou a Origens do totalitarismo e talvez exponha a diferença mais fundamental entre os dois autores. Segundo Voegelin, o fato de Arendt admitir a possibilidade da alteração na natureza não só do ser humano, mas de qualquer coisa, é um "sintoma do colapso da civilização ocidental" porque indica que ela não se atém às essências eternas das coisas. Isto faz com que, diante da "verdadeira linha divisória da crise contemporânea", Arendt não se situe ao lado dos "transcendentalistas religiosos e filosóficos", como ele próprio, mas ao lado dos "imanentistas sectários liberais e totalitários". Arendt aborda esta crítica ao final de sua resposta afirmando que "o sucesso do totalitarismo é idêntico a uma liquidação muito mais radical da liberdade como realidade humana"; a autora garante ainda, não sem certo desdém, que sob "tais condições, haverá muito pouco consolo em se agarrar a uma natureza imutável do homem e concluir ou que o próprio

42 Voegelin, "The Origins of Scientism", p. 190.
${ }^{43}$ Arendt, The Origins of Totalitarianism, p. 347. 
homem está sendo destruído ou que a liberdade não pertence às capacidades essenciais do homem." 44

Arendt não oferece nem aqui nem em lugar algum uma definição positiva, substancial do que é a natureza humana, ideia rejeitada em benefício daquela que intitula $A$ condição humana. O que é notável nesta passagem da resposta é o vínculo entre essência humana e liberdade, apresentado de forma lapidar na seguinte afirmação: "A dominação total é alcançada quando a pessoa humana, que é sempre uma mistura específica de espontaneidade e condicionamento, foi transformada em um ser completamente condicionado cujas reações podem ser calculadas mesmo quando ele é conduzido à morte certa." 45 A concisão desta formulação, retirada de um texto curto redigido pouco depois do fim da redação de Origens do totalitarismo, permite olhar de modo claro para certa composição do ser humano no pensamento de Arendt; não uma definição propriamente, por razões que veremos à frente, mas a indicação de certa estrutura presente nos seres humanos e que parece um traço durável da condição humana: os seres humanos têm uma parte condicionável e outra espontânea. Esta estrutura fundamental oferece o critério para a definição de dominação total e para a consideração dos campos de concentração como a instituição central do totalitarismo, uma vez que os "campos não se destinam apenas ao extermínio de pessoas e à degradação de seres humanos, mas servem também ao horrendo experimento de eliminar, sob condições cientificamente controladas, a própria espontaneidade como expressão do comportamento humano e transformar a personalidade humana em uma mera coisa". ${ }^{46}$ Deste ponto de vista, notamos que o totalitarismo é algo muito mais específico do que uma ditadura moderna. Ele não se contenta em dominar os seres humanos, como fazem as tiranias desde sempre, mas pretende transformar em coisa, não o ser humano, e sim sua espontaneidade, sua personalidade, aquilo que justamente não é condicionável e que, neste sentido, se vincula à liberdade humana. Como vimos acima e continuaremos vendo ao longo desta tese, Arendt recusa a noção de "causalidade histórica" em benefício da noção de evento porque leva a sério certo excesso presente nas ações humanas e resistente a reduções ou explicações totalizantes. Se o totalitarismo é um evento que levou às últimas consequências o esforço de controlar este excesso reduzindo a espontaneidade humana a coisa, ele é um evento que ameaça a própria possibilidade de novos eventos.

\footnotetext{
${ }^{44}$ Arendt, "A Reply to Eric Voegelin", pp. 407-8 - grifo nosso; cf. tb. Voegelin, "The Origins of Totalitarianism", p. 21-2 e Eccel, Entre a política e a metafísica, pp. 57ss.

${ }^{45}$ Arendt, "Social Sciences and Concentration Camps", p. 240

${ }^{46}$ Arendt, The Origins of Totalitarianism, p. 438 - grifos nossos.
} 
As consequências de tal afirmação são enormes e ultrapassam Origens do totalitarismo, ganhando corpo ao longo de A condição humana, livro em que Ricoeur enxerga um esforço para formular a hipótese inversa à de que "tudo é possível" e descobrir traços mais duráveis e mais permanentes da natureza humana. Esta investigação se dará, pretendemos mostrar, em função desta divisão entre o que é condicionável e o que é espontâneo. Se voltarmos a Ricoeur neste ponto, notaremos mais uma contribuição sua na afirmação de que "este tipo de meditação pode ser chamado de antropologia filosófica." 47

Arendt não foi a única sequer a primeira a vincular os campos de concentração à ciência e à técnica. ${ }^{48}$ Tampouco inaugurou o procedimento de procurar os germes da

${ }^{47}$ Ricoeur, "Préface", p. 15

48 Os autores da Escola de Frankfurt estabeleceram ligações entre os acontecimentos políticos na Alemanha e a razão, a ciência e a técnica. Talvez a formulação mais conhecida seja a da Dialética do esclarecimento, em que Adorno e Horkheimer descrevem a catástrofe como o negativo das luzes da razão e suas manifestações, dentre as quais está a razão instrumental, técnica. Segundo Martin Jay, as interpretações do nazismo produzidas pelo Institut podem ser organizadas em duas abordagens gerais e uma delas, adotada por um grupo ao redor de Horkheimer e Friedrich Pollock, "[P]restava cada vez mais atenção na racionalização tecnológica, como força institucional, e na racionalidade instrumental, como imperativo da cultura." (Jay, M $-A$ imaginação dialética. Rio de Janeiro: Contraponto, 2008. pp.220-1) Horkheimer desenvolveu estas ideias em seu Eclipse da razão. Na mesma linha, Herbert Marcuse afirma, no prefácio de Eros e civilização, que "o progresso intensificado parece estar vinculado a uma igualmente intensificada ausência de liberdade. Por todo o mundo da civilização industrial, o domínio do homem pelo homem cresce em âmbito e eficiência. Essa tendência tampouco se apresenta como uma regressão incidental, transitória, na senda do progresso. Os campos de concentração, extermínios em massa, guerras mundiais e bombas atômicas não são 'recaídas no barbarismo', mas a implementação irreprimida das conquistas da ciência moderna, da tecnologia e dominação dos nossos tempos." (Marcuse, H - Eros e civilização. Rio de Janeiro: Zahar, 1968, pp.278) Também Lukács foi à racionalidade, ou melhor, à irracionalidade para tentar explicar Hitler. Em seu Die Zerstörung der Vernunft [A destruição da razão], Lukács se propõe a "desmascarar todos os precursores intelectuais da 'visão de mundo' nacional-socialista, ainda que tenham, em aparência, se distanciado bastante do hitlerismo, ainda que, subjetivamente, jamais tenham tido tais intenções. Uma das teses fundamentais deste livro é: não existe visão de mundo 'inocente'. Isto não existe em nenhum aspecto, em especial com referência ao nosso problema e precisamente no sentido filosófico: a tomada de posição a favor ou contra a razão decide simultaneamente a essência desta filosofia enquanto filosofia e seu papel no desenvolvimento social." (Lukács, G - Die Zerstörung der Vernunft. Band I. Darmstadt: Luchterhand, 1973, pp.10-1) Em sua análise do nazismo, Lukács assume assim uma posição no debate a respeito da culpa alemã sobre a catástrofe e talvez ficasse surpreso se soubesse que Arendt, uma "irracionalista", em carta a Jaspers, outro irracionalista e uma das grandes vozes neste debate sobre culpa alemã, concorda com ele, ao menos à primeira vista: "Tenho agora a suspeita de que, no que se refere a isto que nos foi entregue (Bescherung), a filosofia não é inteiramente inocente. Evidentemente, não no sentido de que Hitler tenha algo a ver com Platão (...) Mas certamente no sentido de que a filosofia ocidental jamais teve um conceito puro do político e nem poderia, pois ela fala necessariamente do homem e trata a pluralidade efetiva de modo acessório. (Arendt- 
catástrofe nas grandes realizações da civilização europeia. ${ }^{49} \mathrm{O}$ que talvez seja distintivo de Arendt é a opção de realizar esta tarefa por meio de uma investigação sobre a vita activa, realizada, como veremos, a partir de uma suspeita contra o papel da ciência e, de modo mais amplo, contra toda a tradição de pensamento político nascida com Platão. Esta suspeita exige a recusa desta tradição e a consequente formulação de uma nova maneira de pensar a política. Em atendimento a esta exigência, Arendt identifica certos elementos totalitários na tradição e, em seguida, formula sua noção de "compreensão", que dá sustento a um novo pensar político; este, por sua vez, é fundamentado em A condição humana, onde a autora nos apresenta um modo de pensar capaz de salvaguardar a personalidade e a espontaneidade dos seres humanos.

Jaspers, Briefwechsel: 1926-1969, carta de 04 de março de 1951.

${ }^{49}$ A crítica de Heidegger ao mundo moderno contida em "A questão da técnica" vai nesta direção. Segundo ele, a essência da técnica é um modo de desvelamento que dispõe para o homem entes como mensuráveis e manipuláveis. Como a modernidade considera, desde seu início, a natureza à maneira de um complexo de forças calculáveis, a disponibilidade dos entes se ampliou significativamente favorecendo os desenvolvimentos da ciência moderna, aqui concebida como uma relação em que o homem requer da natureza. Ao desvelar-se sob o modo da disponibilidade, a natureza se desnaturaliza, se artificializa, e é por isto que, para o homem moderno, uma árvore é, na verdade, um estoque de carvão e madeira; mas a disponibilidade como modo de ser altera também o homem, tanto no sentido de ele perder a natureza pelo artifício quando no sentido de ele mesmo se tornar disponível. A técnica coloca, assim, um desafio no que se refere ao mundo como disponibilidade completa, sem segredos, uniformemente inteligível e controlável, e, consequentemente, inteiramente artificial.(Cf. "A questão da técnica" in: Ensaios e conferências. Petrópolis: Vozes, 2012, pp. 11-38) 


\section{Capítulo 2 - Desmontagem da tradição}

\section{Parte l: suspeita contra a tradição}

Pouco tempo depois de publicar Origens do totalitarismo, Hannah Arendt enviou à Guggenheim Foundation um pedido de bolsa para a realização de uma nova pesquisa. Logo na abertura do projeto, ela afirma que a "brecha mais séria de Origens do totalitarismo está na falta de uma análise conceitual e histórica do background ideológico do bolchevismo. Esta omissão foi deliberada." ${ }^{1}$ Ao expressar esta opinião a respeito do próprio trabalho, Arendt se mostra consciente de certo desequilíbrio notado mesmo pelos leitores mais simpáticos de seu livro, que tem entre suas originalidades a aproximação teórica dos regimes de Adolf Hitler e Josef Stalin, mas termina por entregar ao leitor uma análise conceitual e histórica muito centrada no totalitarismo alemão e comparativamente pouco desenvolvida do totalitarismo soviético. ${ }^{2}$ Considerando a análise histórica ali apresentada, talvez se deva considerar o fato de Arendt ser uma judia alemã que sofrera na própria carne o totalitarismo alemão, tendo sido testemunha ocular da formação do regime hitlerista e acompanhado seus desdobramentos por meio da imprensa, inclusive daquela produzida na língua do regime. Esta tenebrosa proximidade entre Hannah Arendt e o nazismo não se repete com o stalinismo, uma vez que ela não lia russo, não viveu na Rússia e sequer poderia confiar muito naquilo que a imprensa e os primeiros estudos diziam a respeito da URSS. ${ }^{3}$

1 Hannah Arendt-Zentrum (HAZ), container 19.12, "Project: Totalitarian Elements in Marxism". As citações destes documentos são aqui feitas a partir dos originais consultados no Hannah Arendt-Zentrum, em Oldenburg. A colaboração do professor Johann Kreuzer, de Oliver Bruns e sobretudo da simpaticíssima Christine Harckensee-Roth foram fundamentais para o acesso a este e a outros documentos. Ficam aqui expressas minha dívida e gratidão. Este apoio sobre material não publicado nos alinha a Margaret Canovan (e os vários que a seguiram neste ponto), para quem "scholars não podem se dar o luxo de se concentrar em $A$ condição humana a ponto de ignorar seu trabalho anterior, inclusive os escritos não publicados". (Canovan, Hannah Arendt: A Reinterpretation of Her Political Work, p.vii.)

${ }^{2}$ Cf. Voegellin, "The Origins of Totalitarianism"; Arendt, "A Reply to Eric Voegelin"; Baehr, "Debating Totalitarianism: An Exchange of Letters Between Hannah Arendt and Eric Voegelin"; Eccel, Entre política e metafísica: filosofia e política em Hannah Arendt e Eric Voegelin.

${ }^{3}$ Em um prefácio à terceira edição do livro publicada em 1966, Arendt afirma que a situação não era muito melhor para os estudiosos de vinte anos antes, ainda que o regime totalitário já não existisse há mais de uma década, morto junto com Stalin. Cuidado parecido a impediu, em 1966, de afirmar a existência de um governo totalitário na China. (cf. The Origins of Totalitarianism, pp. Xxiii-xxviii. Cf. tb. Nota 34 do primeiro capítulo) 
Considerando, por outro lado, a análise conceitual do background do totalitarismo, as razões apresentadas por Arendt guardam interesse particular e tornam mais evidente a lacuna que ela pretende preencher. Origens do totalitarismo mostra que os elementos históricos que se cristalizaram em movimentos e governos totalitários podem ser rastreados ao longo de certas "correntes subterrâneas" da história ocidental; mostra também que uma série de ideias e conceitos fundamentam o totalitarismo, mas nenhum deles - como o racismo, o imperialismo, o nacionalismo tribal de movimentos de unificação e o antissemitismo - está vinculado a alguma linha respeitável de pensamento. No caso do totalitarismo bolchevique, entretanto, ao lado de ideias e conceitos de segunda linha, encontramos também um "dos mais importantes princípios (tenet) da filosofia política ocidental — o marxismo". ${ }^{4}$ Nesta primeira formulação, portanto, a análise do marxismo ficou de fora de Origens do totalitarismo por ter uma natureza e uma procedência diferentes de todos os demais elementos estudados no livro; ainda que algumas ideias e autores sejam discutidos ao longo do livro, o decisivo é que nada disto vincula o nazismo ao que Arendt chama de "a grande tradição de filosofia política ocidental", para a qual ela se volta neste novo trabalho ao abordar o marxismo. ${ }^{5}$

\footnotetext{
${ }^{4} \mathrm{HAZ}$, container 19.12, "Project: Totalitarian Elements in Marxism".

5 Falta ainda aos estudos arendtianos um trabalho extenso e detalhado a respeito da interpretação arendtiana de Thomas Hobbes, uma vez que ela encontra no autor uma identificação entre os interesses públicos e os privados e a considera "coincidente com a pretensão totalitária". Sob esta coincidência, haveria uma inversão no fato de que Hobbes pretendia proteger o privado, ao passo que o totalitarismo pretendia proclamar sua não existência. (Cf. Arendt, The Origins of Totalitarianism, pp. 139-43, especialmente n.36). Dentro dos limites de artigos, lê-se com proveito: Correia, A - "Arendt sobre Hobbes como verdadeiro filósofo da burguesia" in: INTERthesis, Florianópolis, v.12, n.1, p.147-156, JanJun. 2015. http://dx.doi.org/10.5007/1807-1384.2015v12n1p147; Santos, R. P. — "Hobbes e a filosofia do poder: os 'princípios' antipolíticos do Leviatã na leitura de Hannah Arendt" in: Kriterion: Revista de Filosofia, 58(136), 203-220. https://dx.doi.org/10.1590/0100512x2017n13611rps

O capítulo 6,"Pensamento racial antes do racismo", se dedica à exposição da gênese e de certos traços do pensamento racial desenvolvido ao longo dos séculos XVIII e XIX. Na interpretação de Arendt, as origens e as necessidades políticas a ele vinculado variam de acordo com o país; na França, surge do declínio da aristocracia, então necessitada de um fundamento para sua superioridade fatalmente ameaçada após a Revolução; na Alemanha, é posto pelos liberais nacionalistas interessados em uma união do povo contra a dominação estrangeira e desconfiados do cosmopolitismo da aristocracia a que estavam submetidos; na Inglaterra, apoia-se em Burke e seu elogio do nobre e superior povo inglês, que não deveria se curvar aos abstratos direitos do Homem, mas aferrar-se aos direitos dos ingleses, elaborados, aprimorados e consolidados ao longo da história da ilha. Ainda segundo a autora, não há nada neste pensamento racial capaz de filia-lo à grande tradição de pensamento ocidental, ainda que um ou outro autor de nível tenha contribuido para ele (como 0 interesse romantico pelo exotismo, pelas origens tribais, pela inesgotável personalidade, pela nobreza intacta), ainda que Thomas Mann tenha levado a sério as
} 
A sequência do projeto nos apresenta um esboço da organização de um futuro livro sobre Marx e o totalitarismo, que teria três partes; a primeira dedicada à análise conceitual e as outras duas à análise histórica. No que concerne à história do totalitarismo bolchevique, Arendt previa um estudo da emergência de um partido que, embora nascido em meio a um sistema de partidos que representavam interesses de classe, se apresentava como representante dos interesses de toda a humanidade; haveria também uma pesquisa sobre a formação de grupos e elites revolucionários cuja ação se pautou pela convicção de que os fins justificam os meios; o livro traria também o surgimento de uma ideologia socialistamaterialista que, com o auxílio de ideologias pseudocientíficas do século XIX e da conversa pseudo filosófica de uma "ideia que toma as massas", pretenderia oferecer uma explicação total do ser humano e do universo. A análise histórica traria, por fim, uma descrição da passagem de Lenin a Stalin, oferecendo uma discussão política e histórica do comunismo e do bolchevismo. Previa-se, nesta última parte, uma análise da transformação dos partidos socialistas em sociedades revolucionárias, da primazia da revolução sobre o interesse de classes e da primazia dos "revolucionários profissionais" sobre os membros comuns do partido; estes passos, segundo a hipótese apresentada, teriam sido dados com o auxílio do exército vermelho e da polícia secreta e teriam preparado o caminho para a predominância de certo aparato conspiratório e para a eliminação dos soviets em benefício do partido único.

O leitor familiarizado com Origens do totalitarismo percebe que todos estes elementos de análise histórica elencados no projeto estão presentes na descrição do totalitarismo ali oferecida. ${ }^{6}$ Mas a principal justificativa para esta nova pesquisa, convém lembrarmos, está na análise do elemento que vincula o totalitarismo soviético à tradição de pensamento filosófico ocidental. Toda esta apresentação e análise pormenorizada do

obras do Conde de Gobineau, cujo decadentismo influenciou gente como Baudelaire, Wagner e Nietzsche. A importância deste capítulo para o argumento do livro reside, parecenos, na apresentação da diferença entre um pensamento racial e o racismo. $O$ conceito arendtiano de ideologia aparece aqui para tornar claro o passo dado por Gobineau, que afirma ter encontrado em suas pesquisas sobre as raças, não apenas as diferenças entre elas, mas a verdadeira "chave da história", capaz de explicar todo o decadente movimento da humanidade. Gobineau traduziu eventos históricos em características profundas do self de alguém e "teorizou cientificamente" a ruína (doom) da raça humana em uma catástrofe lenta e natural. A transformação do pensamento racial em racismo, ou seja, em ideologia racista, coloca Gobineau entre os elementos que cristalizaram no totalitarismo algumas décadas depois de sua morte, mas não o coloca na linhagem da tradição.

6 Para a ideia de um partido acima de todos os outros, cf. Arendt, The Origins of Totalitarianism, pp.311-5; para a formação e a função de grupos e elites revolucionários cf. pp. 364-75; para ideologia como explicação total, cf. pp.468-74; para o papel da polícia secreta, cf. pp. 419-37; para a sociedade revolucionária, cf. pp. 375-88. 
totalitarismo soviético viria antecedida de uma primeira parte dedicada a uma análise da obra de Karl Marx. Esta primeira parte seria dividida em cinco itens: (a) o conceito marxista de homem como "animal trabalhador" (working animal); (b) seu conceito de trabalho humano como, de um lado, metabolismo com a natureza e, de outro, construção de um mundo humano; (c) seu conceito de história como história feita pelo trabalho do homem; (d) seu conceito de política, derivado do conceito de história; (e) seu conceito de fim da história como resultado da realização da essência humana pela classe trabalhadora. A primeira parte do livro seria dedicada, portanto, a uma sequência de análises de conceitos de um grande filósofo, procedimento de que Arendt não se serviu em Origens do totalitarismo. ${ }^{7}$

Esta proposta de estudo de Marx já nos permite entrever uma série de questões e temas de A condição humana, Entre passado e futuro e Sobre a revolução, os três livros que Arendt publicou em seguida. ${ }^{8}$ Se conjugarmos a intensa interlocução de Arendt com Marx ao longo destas três obras com o fato de que Arendt nunca desenvolveu a prometida exposição histórica do totalitarismo soviético, ${ }^{9}$ podemos concluir que houve aqui uma decisiva mudança de rota nos estudos da autora. O ano de 1952 parece ter sido particularmente importante para este desvio, uma vez que, em segundo pedido de financiamento (renovação da bolsa) enviado à Guggenheim Foundation em janeiro de 1953 já apresenta grandes diferenças com relação ao pedido inicial e várias semelhanças com o que encontramos nas obras publicadas.

A conhecida distinção entre trabalho (labor) e fabricação (work) já se insinuava no primeiro documento, mas apenas aqui é fixada em termos diferentes e se apresenta junto aos correlatos "animal laborans" e "homo faber" — no primeiro documento, Arendt repete o termo "work" e não emprega o termo "labor". Este desenvolvimento vai ao encontro da centralidade conferida à noção de atividades humanas, marginal no esboço de livro apresentado, mas pilar essencial de A condição humana. Junto à noção de atividades humanas, surge também a ideia de que cada uma delas tem uma temporalidade própria e que existe um equilíbrio entre elas, ideia fundamental para a crítica arendtiana à modernidade -

\footnotetext{
${ }^{7}$ Esta não seria, entretanto, a primeira vez que Arendt centraria seu trabalho em análise de conceitos, pois, lembremos, sua tese de doutorado versou sobre $O$ conceito de amor em Agostinho.

8 Deve-se notar que os artigos que resultaram em Eichmann em Jerusalém foram publicados na The New Yorker antes da publicação de Sobre a revolução, mas este já estava quase inteiramente escrito quando Arendt interrompeu suas atividades para cobrir 0 julgamento de Eichmann. Cf. YOUNG-BRUHEL, For the Love of the World, p. 333-5 e 402; e ADLER, Nos passos de Hannah Arendt, p. 424-32.

${ }^{9}$ Young-Bruhel afirma que o material recolhido para esta exposição foi usado na elaboração de Sobre a revolução. Cf. Young-Bruhel, For the Love of the World, p. 279.
} 
que teria alterado profundamente o equilíbrio entre as atividades.

Mas, deixando momentaneamente de lado estes temas arendtianos, voltemos ao papel que Marx exerce aqui. No primeiro documento, o vínculo entre Marx e a tradição de pensamento já era declarado, mas não havia ali nenhuma qualificação a respeito deste vínculo. Arendt havia deixado claro seu interesse em "fornecer o elo ausente entre o que há de imprecedente em nossa atual situação e certas categorias tradicionais de pensamento político comumente aceitas". Mas ao longo deste primeiro ano de pesquisa ela formulou a relação entre Marx e a tradição e, ato contínuo, se convenceu de que o problema central do totalitarismo seria melhor abordado por meio de uma crítica à tradição, não a Marx:

\begin{abstract}
Marx, em minha opinião, não pode ser adequadamente tratado sem uma consideração da grande tradição de pensamento filosófico e político em que ele próprio está inscrito e que, em certo sentido, atinge seu ápice e fim com ele. Esta foi a principal razão para a omissão dos fundamentos ideológicos do bolchevismo em meu primeiro livro. Esta opinião foi amplamente confirmada (greatly confirmed) por um estudo completo de todo o trabalho do próprio Marx, bem como da literatura mais importante a seu respeito. Portanto, passei a primeira parte de meu ano como bolsista lendo outra vez os grandes trabalhos do pensamento político, em suas línguas originais, começando por Platão e Aristóteles; então Cicero e Santo Agostinho; São Tomás de Aquino; Maquiavel (em inglês); Hobbes, Montesquieu e Rousseau; Kant e Hegel. Eu também tive de me familiarizar com as teorias dos economistas clássicos, especialmente Adam Smith, Ricardo e os fisiocratas. ${ }^{10}$
\end{abstract}

Repete-se aqui a afirmação de uma relação fundamental entre Marx e a tradição, mas com uma série de acréscimos importantes, uma vez que ele aparece não apenas como um filósofo tradicional, mas como o ápice e o fim da tradição. A verdadeira compreensão dos elementos totalitários do marxismo exigiria considerar as proximidades entre Marx e seus antecessores, ainda que estes vínculos não sejam claros à primeira vista. Talvez a principal consequência desta posição arendtiana seja a de que os elementos totalitários não são exclusividade da obra de Marx, mas perpassam tudo aquilo que temos de mais respeitável em termos de pensamento político. A tarefa de uma revisão de toda a tradição surge estreitamente vinculada à resistência ao totalitarismo, "uma ameaça que veio para ficar", e o estudo de Marx não é nada mais que a porta de entrada para esta empreitada. A tarefa se mostra, portanto, muito maior que inicialmente prevista e Arendt parece bastante ciente disto ao terminar seu pedido de renovação da seguinte maneira: "Seria bastante inoportuno de minha parte dar aos senhores neste ponto os detalhes do peso (burden) do livro que eu hesitantemente delineei em minha primeira candidatura, embora eu perceba hoje, depois de

${ }^{10}$ HAZ, container 19.12, "Carta à Guggenheim Foundation de 29 de janeiro de 1953" 
mais de um ano de trabalho intenso, a inadequação da afirmação original."11

Ao se mostrar incompleto e inadequado, o projeto de livro sobre os elementos totalitários no marxismo foi prontamente abandonado, gesto bastante significativo no que se refere às preocupações fundamentais de Hannah Arendt. Embora inserida na Guerra Fria e muito grata pela acolhida que os EUA lhe ofereceram, Arendt jamais se sentiu atraída pelo antimarxismo então em voga na sociedade e academia americanas. Demonstrando disposição oposta, ela antepôs ao terceiro capítulo de $A$ condição humana, uma nota em que pede para não ser confundida com os "antimarxistas profissionais" e, mais do que isto, ao longo do capítulo colocou no mesmo plano de Marx alguns autores que costumam servir de fundamento para os antimarxistas, como John Locke e Adam Smith. No processo de compreensão dos "elementos totalitários no marxismo", Arendt se viu diante de "elementos totalitários na tradição" e se lançou intensamente à compreensão destes elementos. É importante notarmos que este desenvolvimento do projeto de pesquisa se vincula a um dos impulsos fundamentais de Origens do totalitarismo, livro "escrito a partir da convicção de que deve ser possível descobrir os mecanismos escondidos que dissolveram todos os elementos tradicionais de nosso mundo político e espiritual em um conglomerado onde tudo parece ter perdido seu valor específico e se tornado irreconhecível à compreensão humana, inútil para fins humanos." 12 Embora seja importante notar o significado da mudança ocorrida ao longo do ano de 1952, deve-se prestar atenção igualmente àquilo que permanece do elã inicial da obra de Arendt elaborada depois da catástrofe, que a moveu ao longo de todo o livro anterior, se renova aqui e a norteará em todas as suas obras posteriores. Esta preocupação fundamental de Hannah Arendt com os elementos do totalitarismo parece se fundar no amor por este "nosso mundo político e espiritual" que motivou a redação de Origens do totalitarismo e se expressa no alerta que encerra um de seus últimos capítulos: "Soluções totalitárias podem sobreviver muito bem ao fim dos regimes totalitários na forma de fortes tentações que surgirão sempre que parecer impossível aliviar a miséria política, social ou econômica de maneira digna do homem."13

Além da permanência da preocupação com o totalitarismo, o trecho do pedido de renovação de bolsa acima citado traz-nos ainda outros componentes importante. Talvez o mais decisivo deles seja uma suspeita contra a tradição, que anima todo o seu trabalho pelos anos seguintes. Esta suspeita aparece aqui, mas já havia sido expressa em uma carta escrita

${ }^{11}$ HAZ, container 19.12, "Carta à Guggenheim Foundation de 29 de janeiro de 1953"

${ }^{12}$ Arendt, The Origins of Totalitarianism, p. viii 
em março de 1951 a Karl Jaspers, que a esta altura já havia publicado seu livro sobre a questão da culpa (Schuld) alemã na catástrofe e se afirmava como a grande voz deste debate. "Tenho agora a suspeita (Verdacht) de que, no que se refere a isto que nos foi entregue, a filosofia não é inteiramente inocente (unschuldig). Evidentemente, não no sentido de que Hitler tenha algo a ver com Platão (...) Mas certamente no sentido de que a filosofia ocidental jamais teve um conceito puro do político e nem poderia, pois ela fala necessariamente do homem e trata a pluralidade efetiva como algo acessório. Mas eu não deveria ter escrito isto, pois ainda não está nada desenvolvido. Desculpe-me."14 No projeto de pesquisa, a suspeita se revela na ideia de uma relação entre Marx, a tradição e o totalitarismo, expressa como a justificativa de uma ausência no livro anterior, cuja redação se desenvolveu entre 1945 e 1949. ${ }^{15}$ Assim, embora Marx só seja apresentado como o ápice e o fim da tradição no início de 1953, é possível afirmar que esta suspeita da relação entre tradição e totalitarismo existe desde pelo menos 1949, ainda que tenha sido necessário esperar até 1952 para que fosse formulada e "amplamente confirmada". ${ }^{16}$

Podemos concluir imediatamente desta suspeita e de sua confirmação a exterioridade de Arendt com relação à tradição. Pelo menos desde os anos 1940, ela se vê como quem está fora da tradição, como quem pensa no momento em que a filosofia perdeu sua atualidade ${ }^{17}$, no momento em que é necessário reconsiderar les préjugés classiques. ${ }^{18}$ Esta posição exige a decisão entre a tentativa de restabelecer a ligação com a tradição e a ratificação do rompimento: Arendt se coloca inequivocamente na ruptura. Se a releitura dos grandes autores

\footnotetext{
${ }^{13}$ Arendt, The Origins of Totalitarianism, p.459.

${ }^{14}$ Arendt-Jaspers, Briefwechsel: 1926-1969, carta de 04 de março de 1951.

15 Talvez seja possível afirmar que o início da redação seja mais antiga, uma vez que "Antissemitismo", texto redigido por volta de 1938 e 1939 e publicado apenas postumamente, já adianta uma série de problemas e argumentos presentes na primeira parte de Origens do totalitarismo. Cf. Arendt, "Antissemitismo" in Escritos judaicos.

${ }^{16}$ Esta suspeita somada à pronta mudança de ponto de vista da pesquisa nos leva a considerar que a ênfase sobre Marx na redação do projeto de pesquisa talvez possa ter sido uma estratégia para aumentar as chances de ter seu pedido de financiamento aprovado. O projeto, em que Marx é o alvo direto, foi aprovado pela agência financiadora, mas o pedido de renovação, em que o papel de Marx é menor e o da tradição é maior, foi recusado sob a alegação de que "os fundos disponíveis, embora maiores que anteriormente, não foram suficientes." (HAZ, container 19.12, "Carta da John Simon Guggenheim Memorial Foundation a Hannah Arendt" de 20 de abril de 1953.) Durante a Guerra Fria, o governo americano destinou dinheiro à "guerra cultural" financiando obras de diversos artistas e intelectuais por meio de várias instituições. De acordo com Frances Saunders, Hannah Arendt foi financiada, de modo mais ou menos consciente, em algumas ocasiões ao longo de sua vida (Saunders, F - The Cultural Cold War. New York: New Press, 2000)

${ }^{17}$ Cf. Adorno, "A atualidade da filosofia" e A dialética negativa.
} 
da tradição ao longo de 1952 confirmou a suspeita de que ela contém elementos totalitários, a luta contra o totalitarismo deve necessariamente incluir uma completa destruição da tradição. Dada a proximidade entre a tradição e o totalitarismo, o esforço para reatar com a tradição que parece animar Voegelin e Leo Strauss, por exemplo ${ }^{19}$ - equivale a dar sobrevida a elementos que cristalizaram no totalitarismo; risco igualmente partilhado pelo pensamento que ignora a ruptura e considera que a filosofia se mantém atual. Embora a obra arendtiana não demonstre muitas esperanças de que algum dia nos livraremos definitivamente da ameaça do totalitarismo, a necessidade de combatê-lo de todas as formas possíveis se impõe e a completa destruição da tradição se apresenta como consequência do reconhecimento do totalitarismo como ameaça nova e radical que exige cuidados igualmente novos e radicais.

Esta posição de distância com relação à tradição se manteve com Arendt até o fim. Em seu último livro, ela reclama explicitamente a filiação junto àqueles "que, já há algum tempo, vem tentando desmontar a metafísica e a filosofia, com todas as suas categorias, do modo como as conhecemos, desde o seu começo, na Grécia, até hoje. Tal desmontagem só é possível se aceitarmos que o fio da tradição está rompido e que não podemos reatá-lo." ${ }^{20} \mathrm{Ou}$ seja, Arendt se insere declaradamente em um movimento mais amplo e anterior a ela dedicado à desmontagem da tradição, o que nos remete diretamente a seus anos de formação na Alemanha da República de Weimar, quando o tema ganhou particular importância.

Mas isto ainda deixa algumas perguntas importantes. No contexto preciso desta passagem da obra de Arendt, onde incide exatamente sua suspeita contra a tradição? Além disto, o que foi exatamente que confirmou amplamente sua suspeita contra ela?

Se considerarmos que, na teoria arendtiana do totalitarismo, o que caracteriza a instituição central desta forma de governo é a tentativa de alterar a natureza humana e, além disto, se nos lembrarmos que o trabalho de Arendt imediatamente posterior a estes esforços se chama A condição humana, notaremos que a questão do humano tem grande centralidade aqui. Se, dando ainda um passo, nos lembrarmos de que o humanismo foi um dos grandes temas que animou o debate filosófico ao longo do século XX até o final dos anos 1960, quando, para falar com Pierre Aubenque, decidiu-se que o problema do humanismo estava

${ }^{18}$ Cf. Merleau-Ponty, Fenomenologia da percepção.

${ }^{19}$ Cf. Strauss, "O que é filosofia política?", "Sobre a filosofia política clássica" e "Progresso ou retorno? A crise contemporânea da civilização ocidental." In: Uma introdução à filosofia política: dez ensaios. Cf. tb. Zuckert, C - "Strauss' Return to Premodern Thought" in: Smith, S. (ed.) - The Cambridge Companion to Leo Strauss.

${ }^{20}$ Arendt, The Life of The Mind, p.212 
encerrado, ${ }^{21}$ notaremos que esta discussão tem um lugar importante na obra de Arendt e, inversamente, Arendt tem um lugar importante nesta discussão.

Embora os estudos arendtianos não costumem se lançar sobre o tema do humanismo, o movimento parece necessário. Em primeiro lugar, pelo simples fato de uma de suas principais obras ser dedicada ao problema da condição humana. Em segundo, e de modo mais decisivo, porque ela mesma elegeu este tema e os autores a ele relacionados quando pretendeu descrever um panorama da filosofia de seu tempo e, ainda mais, quando elaborou alguns elementos daquilo que viria a ser a maneira adequada de pensar a política póstotalitarismo. Vejamos, portanto, dois movimentos em que a ruptura com a tradição e o problema do humano se cruzam. Um, em certo debate alemão realizado nos anos de formação de Arendt; em seguida, nos diálogos que ela mesma estabelece com este debate no período de sua obra aqui analisado.

\section{A questão do humano no debate alemão}

Ao afirmar, como vimos acima, que $A$ condição humana resulta de uma meditação que pode ser chamada de antropologia filosófica, Ricoeur pretende indicar que o livro se insere em uma disciplina tradicional da filosofia preocupada com o que é especificamente humano, em contraposição as outras criaturas ou coisas. ${ }^{22}$ Este tipo de preocupação esteve particularmente em voga no cenário alemão do início do século $\mathrm{XX}$, a ponto de surgir, na década de 1920, um movimento específico que se autointitulava o da "antropologia filosófica", ${ }^{23}$ representado especialmente por Max Scheler, Helmut Plessner e Arnold Gehlen. ${ }^{24}$ Cada um à sua maneira, estes autores se dedicaram a pensar filosoficamente o

${ }^{21}$ Aubenque é mais específico e afirma que o maio de 68 pretendeu ter encerrado, e o fez em alguma medida, o "debate parisiense sobre o humanismo suscitado pela Carta [sobre 0 humanismo] de Heidegger." O encerramento não se deu, como pensaram muitos à época, pela abertura de uma nova era no mundo e no pensamento, embora se deva aceitar que o espírito do tempo foi deslocado para outras paragens e abriu novos horizontes. Aubenque, "Du débat de Davos (1929) à la querelle parisienne sur l'humanisme (1946-1968): genèse, raisons et posterité de l'anti-humanisme heideggerien", p. 237.

${ }^{22}$ Cf. verbete "Philosophical antropology" do The Cambridge Dictionary of Philosophy. (Second Edition: Robert Audi)

${ }^{23}$ De modo muito preciso, Joachim Fischer data o início do movimento em 1919, quando Scheler, recém nomeado na universidade de Colônia, convidou Plessner para ir à "nova Alexandria"; o fim teria se dado em 1975, com a morte de Gehlen, pouco antes da de Plessner. Cf. Fischer, Philosophische Anthropologie, p.11

${ }^{24}$ A revista Merkur publicou uma resenha elogiosa de Gehlen à edição alemã de $A$ condição humana, livro em que ele é citado, aliás (Gehlen, A - "Vita activa, oder Vom tätigen Leben" in: Merkur, Deutsche Zeitschrift für europaisches Denken - Mai 1961, 15. Jahrgang, Heft 
humano à luz das exigências impostas pelo desenvolvimento das ciências biológicas visto até então; em outros termos, o esforço destes autores representa uma afirmação da importância da filosofia diante da ciência e sua pretensão de, ao explicar tudo, relegar a filosofia a um papel coadjuvante, ou mesmo meramente decorativo.

O lugar do homem no cosmos é um livro fundamental para o movimento porque, entre outros aspectos, apresenta uma espécie de esboço programático da antropologia que Scheler pretendia desenvolver ${ }^{25}$ — um projeto interrompido pela morte prematura de seu autor no ano de publicação do livro. (Na edição alemã de A condição humana, aliás, Arendt inclui ao menos uma referência direta ao livro, no momento do prólogo em que a Terra é descrita como a quintessência da condição humana e a natureza terrestre como a única capaz de oferecer um habitat para o ser humano. $)^{26}$

Logo no prefácio, Scheler afirma ter "a satisfação de constatar que os problemas de uma antropologia filosófica ganharam hoje o ponto central de toda a problemática filosófica na Alemanha e que, muito para além do círculo dos especialistas em filosofia, há biólogos, médicos, psicólogos e sociólogos trabalhando em uma nova imagem da constituição essencial do homem." ${ }^{27}$ Scheler está ciente de que a questão não é nova e que tanto a tradição judaicocristã quanto a tradição nascida na Grécia fornecem antropologias que informam o conteúdo da palavra "homem" toda vez que é pronunciada por um "europeu culto". O que confere centralidade à questão no início do século XX é o enorme desenvolvimento verificado ao longo das décadas precedentes pelas ciências que têm no ser humano seu objeto e permitem

159, pp 482-486; Cf. Arendt, The Human Condition, p. 177 N.1) Há um comentário a respeito no sítio do Bard College (http://hac.bard.edu/news/?p=10515 — acessado em 23.12.2017). Segundo Jean Greisch, Gehlen afirmou em mais de uma ocasião ter estreitas afinidades com o pensamento político de Arendt (Greich, Qui sommes nous?, p.46.); segundo Habermas, $A$ condição humana apresenta "uma antropologia da ação linguística que pode ser considerada como um equivalente da antropologia da ação racional com relação a fins desenvolvida por Arnold Gehlen" (Habermas, J - "El concepto de poder de Hannah Arendt", p.209.

${ }^{25}$ Cf. Greisch, Qui sommes-nous, pp. 14-23.

${ }^{26} \mathrm{O}$ quarto parágrafo do prólogo na edição alemã se inicia assim: "Denn wie immer es um 'die Stellung des Menschen im Kosmos' bestellt sein mag, die Erde und die irdische Natur scheinen zumindest insofern einzigartig im Weltall zu sein, als sie solchen Wesen, wie Menschen es sind, die Bedingungen bereitstellen, unter denen sie ohne Umstände und ohne auf von ihnen selbst ersonnene Mittel angewiesen zu sein, leben und sich bewegen und atmen können." [Pois, qualquer que possa ser 'o lugar do homem no cosmos', a Terra e a natureza terrestre parecem ser únicas no universo, pois somente elas fornecem a estes seres, os homens, as condições sob as quais podem viver, se movimentar e respirar sem esforço e sem depender de qualquer recurso construído por eles mesmos.](Arendt, Vita activa, p.9)

${ }^{27}$ Scheler, A posição do homem no cosmos, p.3 
afirmar com certeza uma série de verdades a seu respeito sem que elas apontem para um conceito adequado do que seja o ser humano. A antropologia fornecida pelas ciências e presente na influente resposta darwinista ao problema, segundo a qual não existe salto qualitativo entre os humanos e os animais, contribuiu decisivamente para a renovação da urgência de uma nova concepção de ser humano, capaz de incluir as descobertas recentes das ciências, mas sem reduzir o humano a um mamífero vertebrado; ou seja, Scheler se preocupa com um conceito de humano que acompanhe as descobertas das ciências que o têm como objeto, mas sem perder de vista a "ambiguidade insidiosa" do conceito, que também aponta para aquilo que no humano se contrapõe ao conceito de "animal em geral". "Nesse sentido, possuímos uma antropologia científico-natural, uma antropologia filosófica e uma teológica que não se preocupam umas com as outras. Mas não possuímos uma ideia una do homem" 28

A saída elaborada por Scheler parte da ideia de que a "posição peculiar do homem só se tornará distinta para nós se tivermos em vista a construção conjunta do mundo biopsíquico", ${ }^{29}$ e se desenvolve pela descrição de certos "estágios essenciais" que permitem uma organização dos seres vivos em diferentes níveis - impulso afetivo (planta), instinto (animal), memória associativa e inteligência prática — conduzindo a argumentação à questão da differentia specifica do ser humano. Neste ponto, os evolucionistas recusam a existência de qualquer elemento distintivo no humano, uma vez que reconhecem inteligência nos animais. Do outro lado, há quem, negando a inteligência e o poder de escolha aos animais, reconheça "uma diferença supraquantitativa, uma diferença essencial, mas afirmam-na onde segundo meu modo de ver não se apresenta nenhuma diferença essencial." 30 Faz-se necessário, portanto, apontar para a diferença entre o humano e o animal com base em um novo princípio, a saber, o espírito, aqui concebido como abertura para o mundo e autoconsciência em pura atualização. ${ }^{31}$

Embora fora da "trindade" da antropologia filosófica, formada por Scheler, Plessner e Gehlen, Ernst Cassirer se aproximou bastante do movimento. ${ }^{32}$ Seu Ensaio sobre o homem

\footnotetext{
${ }^{28}$ Scheler, A posição do homem no cosmos, p. 5 - grifos no original.

${ }^{29}$ Scheler, A posição do homem no cosmos, p.8.

${ }^{30}$ Scheler, A posição do homem no cosmos, p. 34

${ }^{31}$ Cf. Scheler, A posição do homem no cosmos, pp. 36-46

${ }^{32}$ Segundo o verbete "philosophical antropology" da segunda edição de The Cambridge Dictionary of Philosophy, o Ensaio sobre o homem de Cassirer, bem como a Critica da razão dialética de Sartre são representantes tardios do movimento. Fischer não parece conferir lugar de relevo a Sartre dentro do movimento, mas considera Cassirer um membro importante, ainda que este tenha entrado tardiamente na "constelação antropológica". Cf. Fischer, Philosophische Anthropologie, pp.101-7.
} 
(1940) se inicia com um diagnóstico bastante parecido com o de Scheler a respeito do conhecimento sobre o ser humano. Também Cassirer constata uma crise no autoconhecimento humano resultante dos desenvolvimentos das ciências que o têm como objeto, mas conflitam entre si porque não são articuladas a um conceito claro de ser humano. "Nietzsche proclama a vontade de potência, Freud sinaliza o instinto sexual (sexual instinct) e Marx entrona o instinto econômico (economic instinct). Cada teoria se transforma em um leito de Procusto em que fatos empíricos são esticados para se adequar a um padrão préconcebido." ${ }^{33}$ Sua proposta de saída para a crise detectada se baseia expressamente nas descobertas então recentes do biólogo Johannes von Uexküll, para quem a realidade não é una, mas imensamente diversificada, pois formada por inúmeros organismos estruturados em padrões distintos. À maneira de uma mônada, cada organismo é dotado de um sistema receptor e de um sistema efector, e contém em si mesmo um mundo próprio fundado em uma experiência própria. "No mundo de uma mosca, diz Uexküll, encontramos apenas 'coisas de mosca'; no mundo de um ouriço-do-mar, encontramos apenas 'coisas de ouriço-do-mar". ${ }^{34}$ Cassirer considera possível fazer uso do esquema proposto por Uexküll para descrever e caracterizar o mundo humano. Faz-se necessário, no entanto, introduzir uma alteração fundamental no esquema do biólogo porque, embora o ser humano não seja uma exceção às regras biológicas que regem os demais organismos, não se pode deixar de considerar que existe uma diferença qualitativa entre a vida humana e as demais. "Entre o sistema receptor e o sistema efector, encontrados em todas as espécies animais, encontramos no homem um terceiro elo que podemos descrever como o sistema simbólico. Esta nova aquisição transforma inteiramente a vida humana." ${ }^{35}$ É com base nesta tripartição de sistemas que o autor da Filosofia das formas simbólicas elabora a noção de ser humano que dá sustentação a seu pensamento.

Notamos com isto que, tanto em Scheler quanto em Cassirer, a questão do humano é decisiva para seu tempo, muito em função da extensão e do sucesso do discurso científico a respeito dos mais variados aspectos do ser humano. Seu procedimento é o de definir o humano por meio da busca por sua differentia specifica relativamente aos demais animais. $\mathrm{O}$ privilégio conferido por eles à biologia não deve nos fazer esquecer que a definição do humano a partir do animal é procedimento tradicional e presente mesmo em autores que não tem qualquer relação com a biologia. Uma das exigências desta maneira de pensar é a

${ }^{33}$ Cassirer, An Essay on Man, p.39

${ }^{34}$ Cassirer, An Essay on Man, p. 41 
determinação, a mais exaustiva possível, dos elementos que formam a natureza humana e, neste sentido, o pensamento destes autores se converte em um humanismo. Assim concebido, o humanismo não se expressa necessariamente por uma doutrina edificante dedicada à diferenciação entre ações dignas e indignas de seres humanos, embora isto possa ocorrer; mais fundamentalmente, ele representa ainda um esforço para o estabelecimento, por meio de uma investigação racional, dos conteúdos positivos, essenciais, imutáveis, específicos do ser humano.

A esta "virada antropológica" na filosofia alemã seguiu-se uma "contrarrevolução" fenomenológica capitaneada por Husserl e Heidegger. ${ }^{36}$ Dadas as proximidades teóricas e pessoais entre os autores das duas vertentes, esta revolução foi inicialmente tomada como diferenças no interior da fenomenologia e da antropologia filosófica, movimentos que se sobrepunham em larga medida. Max Scheler, por exemplo, era então visto como o segundo grande nome da fenomenologia, atrás apenas de Husserl. ${ }^{37}$ Heidegger precisou afirmar reiteradas vezes que, apesar da centralidade da analítica do Dasein, Ser e tempo não é um livro sobre o ser humano, mas sobre o ser. De acordo com Jean Greisch, esta contrarrevolução fenomenológica é composta por uma conferência dada por Husserl em Frankfurt em 1931 - em que ele retoma certos argumentos das Investigações lógicas contra o "psicologismo" e afirma ainda que a analítica do Dasein e a filosofia da vida de Dilthey são novas figuras de uma antropologia de consequências inquietantes - e pela obra de Heidegger produzida entre 1919 e 1938, que, em três fases distintas, apresentou diferentes faces da desconstrução radical da antropologia filosófica e deu a ocasião para Heidegger esclarecer suas distâncias inconciliáveis com o movimento. ${ }^{38}$

O brevíssimo período entre os anos de 1927 e 1929 é particularmente significativo neste debate entre a antropologia filosófica e a fenomenologia. Isto porque em 1927 ocorre a publicação de Ser e tempo, em 1928, a de O lugar do homem no cosmos e de Die Stufen des Organischen und der Mensch: Einleitung in die philosophische Anthropologie [Os níveis do orgânico e do homem: introdução à antropologia filosófica], de Plessner, e, em 1929, o

\footnotetext{
${ }^{35}$ Cassirer, An Essay on Man, p. 42-3 - grifo no original

${ }^{36}$ Os termos são de Greich, embora Fischer também fale em uma "virada antropológica". Talvez venham de fonte mais antiga. Cf. Fischer, Philosophische Anthropologie, p.101; Greisch, Qui sommes-nous?, p.53

37 A afirmação é de Spiegelberg, que, embora se diga aliviado por não ter que julgar a contribuição de Scheler à fenomenologia, dedica a ele um lugar de destaque em sua monumental história do "movimento fenomenológico". Cf. Spiegelberg, The Phenomenological Movement, p.228ss.

${ }^{38}$ Cf. Greisch, Qui sommes-nous?, pp.53-83.
} 
célebre debate entre Heidegger e Cassirer em Davos, que recebeu enorme atenção na época e já então apareceu aos participantes como um momento decisivo no pensamento europeu. Emmanuel Lévinas, então aluno de Husserl na Alemanha, esteve no evento e afirmou mais tarde que "um estudante jovem poderia ter a impressão de estar assistindo à criação e ao fim do mundo." ${ }^{39}$ Esta impressão não se refere apenas à sensação de estar diante de algo intelectualmente grande, o que foi efetivamente o caso, ${ }^{40}$ mas também à sensação de que o humanismo representado por Cassirer chegara a seu fim ali, junto com sua participação opaca e derrotada no evento, ao mesmo tempo em que o desempenho vibrante de Heidegger parecia apontar para um pensamento novo e pujante.

\begin{abstract}
[D] adas as diferenças de idade e de estágio na carreira entre os dois homens (Cassirer tinha 55 anos, Heidegger nem bem 40; Cassirer estava na cadeira de filosofia em Hamburgo desde 1919, Heidegger assumiria a cadeira de Husserl em Freiburg naquele ano), o encontro envolveu todo o drama de uma transição de geração. De fato, parece que Heidegger convenceu os jovens estudantes em Davos e, de todo modo, não há dúvidas de que a revolta de Heidegger contra o 'racionalismo' da tradição neokantiana seria brilhantemente exitosa por todo o continente europeu e mesmo além dele. ${ }^{41}$
\end{abstract}

Vários acadêmicos apresentaram seus trabalhos ao longo das mais de três semanas do encontro, mas as atenções estavam voltadas particularmente para as palestras independentes que Cassirer e Heidegger dariam ao longo do evento em preparação para o grande debate a ser travado pelos dois frente a frente. ${ }^{42}$ Ao longo das palestras, ambos trataram de temas que

${ }^{39}$ Citado por Gordon, Continental divide, p. 2

40 Michael Friedman atribui ao evento importância ainda maior, pois Rudolf Carnap esteve em Davos, conversou com Heidegger e decidiu em seguida romper com a grande tradição metafísica ocidental substituindo-a pela análise lógica da linguagem. Segundo Friedman, o resultado deste movimento nascido ali foi a separação entre filosofia analítica e filosofia continental. Cf. Friedman, A Parting of the Ways; Cf. tb. Gordon, Continental divide.

41 Friedman, $A$ parting of the Ways, p. 3. Para a impressão na época, cf. Gordon, Continental Divide, pp. 329-35; para a impressão do pós-guerra, pp. 335-4. Em seu livro dedicado a Arendt e Heidegger, Antonia Grunenberg também destina atenção ao evento, embora com preocupações diferentes. Cf. Grunenberg, Hannah Arendt et Martin Heidegger, pp. 136-48.

${ }_{42}$ Uma transcrição do debate foi publicada nas Gesamtausgabe de Heidegger em meio a outros anexos dedicados à discussão com Cassirer (Band III - Kant und das Problem der Metaphysik. Anhang IV. p.274-296. Frankfurt am Main: Vittorio Klostermann). Esta transcrição foi recentemente traduzida para o português por André Perez e apresentada por Rafael Garcia ("Disputa de Davos entre Ernst Cassirer e Martin Heidegger" in: Cadernos de Filosofia Alemã. v. 22; n. 1. pp.157-178). O quarto capítulo do livro de Peter Gordon traz também uma tradução do debate intercalada com extensos comentários do autor (Gordon, Continental Divide, pp. 136-214). Pierre Aubenque reuniu, apresentou e, junto a J-M Fataud e P. Quillet, traduziu alguns textos que compõem o embate entre Cassirer e Heidegger, dentre os quais os textos das palestras preparatórias e a transcrição do debate (CASSIRER, E / HEIDEGGER, M - Débat sur le kantisme et la philosophie (Davos, mars 1929) et autres textes de 1929-1931 présentés par Pierre Aubenque. Paris: Beauchesne, 
costumavam ser associados ao outro, testemunhando a proximidade entre o movimento fenomenológico e a antropologia filosófica em suas origens. Embora Cassirer fosse associado ao neokantismo de Marburg, foi Heidegger quem tratou de Kant apresentando pela primeira vez sua interpretação da Crítica da razão pura que pouco mais tarde seria publicada na forma de livro, Kant und das Problem der Metaphysik, e dedicada à memória de Max Scheler, falecido em $1928 .{ }^{43}$ Apesar de sua insistência e esforços em contrário, Heidegger era então bastante associado ao movimento da antropologia filosófica, mas foi Cassirer quem tratou do tema em suas palestras preparatórias, que também versaram sobre Scheler. A desconexão entre as palestras preparatórias era apenas aparente, pois com elas os dois filósofos atenderam ao pedido dos organizadores de tratar da famosa quarta questão de Kant — o que é o homem? - que ganhava interesse renovado na cena alemã em função da antropologia filosófica e estava também intimamente vinculada à analítica do Dasein. ${ }^{44}$

Apesar da enorme dificuldade imposta pela divergência de vocabulário existente entre os dois autores - dificuldade que suscitou a única intervenção no debate - e pelas voltas ao redor da interpretação de Kant, nota-se que muito do problema do humano se faz presente na discussão a respeito do ponto de partida e de chegada da filosofia de cada um dos autores, à qual se vincula a questão da passagem do finito ao infinito. Cassirer entende a finitude como um ponto de partida (terminus ad quo) que o ser humano deve superar com o auxílio da razão em direção ao mundo inteligível. A ação do sistema simbólico, presente apenas no ser humano, resulta na progressiva elucidação das figuras da consciência, de modo que o ponto de chegada (terminus ad quem) seja uma filosofia da cultura, capaz de conhecer o humano por meio dos símbolos que ele se mostra capaz de elaborar ao longo do tempo. Contra este humanismo, Heidegger se coloca de modo resoluto - e mesmo um tanto grosseiro - com uma afirmação "decisiva e responsável por muita inquietação" ${ }^{45}$ que pretende apontar com clareza para a distinção mais fundamental entre os dois naquele debate.

A pergunta pela essência do homem só tem sentido e só se justifica se for motivada
pela problemática central da própria filosofia, que conduz o homem para fora de si
mesmo e para a totalidade do ente a fim de tornar manifesto aí para ele, em toda a sua
liberdade, o nada [Nichtigkeit] de seu Dasein. Um nada que não é motivo para
pessimismo ou melancolia, mas para a compreensão de que a efetividade autêntica
(das eigentliches Wirken) está apenas lá onde há oposição, e que a filosofia tem a

1972).

${ }^{43}$ No prefácio à primeira edição, lê-se: "Este trabalho é dedicado à memória de Max Scheler. Seu conteúdo foi tema da última conversa com o autor, ocasião em que pudemos sentir uma vez mais a irrefreada força deste espírito.

${ }^{44}$ Cf. Ser e tempo, $\S 10$ e $\S 11$; cf. tb. Kant e o problema da metafísica, §36 e §37; cf. tb. Gordon, Continental Divide, pp. 69-77

${ }^{45}$ Cf. Aubenque, "Du débat de Davos (1929)...", p.228 
tarefa de, arrancando o homem de seu mais preguiçoso aspecto, que se resume ao uso das obras do espírito, lançá-lo, por assim dizer, de volta à dureza de seu destino. ${ }^{46}$

Heidegger toma aqui a finitude como ponto de partida e de chegada da reflexão filosófica e interpreta o sistema simbólico de Cassirer como um encobrimento dele. Em vez de liberar-se da finitude do sensível caminhando rumo ao reino da forma simbólica a fim de alcançar o infinito, Heidegger propõe um movimento no interior da finitude, rumo ao conflito que reside na essência da liberdade, rumo ao centro da existência. Contra o humanismo que enxerga nas obras do espírito, nas formas simbólicas, a expressão do conteúdo específico do que é o humano, Heidegger propõe a investigação a respeito do vazio constitutivo da existência humana, do Dasein. Neste sentido muito preciso, a posição de Heidegger aparece como um anti-humanismo. Não como um elogio da crueldade, oposta à caridade associada à ideia de "humano", ${ }^{47}$ nem como elogio da baixeza, oposta às elevadas e edificantes possibilidades da civilização, mas como uma posição que aceita radicalmente o indeterminável abismo constitutivo do humano.

Embora Heidegger tenha insistido inúmeras vezes que sua filosofia não era uma

${ }^{46}$ Este trecho de difícil tradução é aqui apresentado em tradução nossa, baseada no texto alemão e nas traduções para o português, francês e inglês acima referidas. O original diz o seguinte: ...die Frage nach dem Wesen des Menschen hat einzig nur den Sinn und das Recht, daß sie motiviert ist aus der zentralen Problematik der Philosophie selbst, die den Menschen über sich selbst hinaus und in das Ganze des Seienden zurückzuführen hat, um ihm da bei all seiner Freiheit die Nichtigkeit seines Daseins offenbar zu machen, eine Nichtigkeit, die nicht Veranlassung ist zu Pessimismus und zum Trübsinn, sondern zum Verständnis dessen, daß eigentliches Wirken nur da ist, wo Widerstand ist, und daß die Philosophie die Aufgabe hat, aus dem faulen Aspekt eines Menschen, der bloß die Werke des Geistes benutzt, gewissermaßen den Menschen zurückzuwerfen in die Härte seines Schicksals. "Davoser Disputation zwischen Ernst Cassirer und Martin Heidegger" in: Martin Heidegger Gessamntausgabe, Band III - Kant und das Problem der Metaphysik. Anhang IV. P. 291.(Cf. tb. Disputa de Davos entre Ernst Cassirer e Martin Heidegger", p. 174-5; Gordon, Continental divide, p. 200; Aubenque, Débat sur le kantisme et la philosophie, p. 46.)

47 Tocamos aqui em um tema delicado e já antigo, a saber, a relação entre Heidegger e o nazismo. O tema aparece aqui não apenas pelo caráter desumano da política nazista, à qual Heidegger deu entusiasmado apoio, mas porque a questão recentemente passou por desenvolvimentos significativos com a publicação, por um lado, do assim chamados "Cadernos negros", que documentam irrefutavelmente o antissemitismo de Heidegger ao longo de toda a sua vida, e, por outro, com a ruidosa discussão ao redor da tese de Emmanuel Faye, segundo a qual não é possível separar a vida e a obra de Heidegger no que se refere ao nazismo porque sua obra seria o resultado de uma "introdução deliberada dos fundamentos do nazismo e do hitlerismo na filosofia." (Faye, Heidegger: a introdução do nazismo na filosofia, p. 19). A questão é espinhosa e seu tratamento minimamente responsável escaparia por muito os limites deste trabalho, sobretudo porque deveria incluir também o livro mais recente do autor, dedicado às relações entre Arendt e Heidegger, o que não foi possível dentro do prazo para o depósito da tese. 
reflexão prioritariamente preocupada com o ser humano, mas com a do ser, sua ontologia fundamental propôs uma nova maneira de enxergar o humano, pois, ao levar a sério e às últimas consequências a finitude, a ontologia fundamental introduziu um vazio essencial no conceito de humano e tornou difícil a posição humanista, vinculada a um esforço de determinar a differentia specifica do ser humano e definir seus elementos constitutivos. ${ }^{48}$ Prova do impacto da ontologia fundamental sobre o humanismo está na permanência da questão no pensamento de Heidegger, abordada de modo central em "A época da imagem do mundo" (1938), "A doutrina platônica da verdade" (1940) ${ }^{49}$ e "Carta sobre o humanismo" $(1946) . .^{50}$

Como se sabe, a ocasião para a publicação da "Carta sobre o humanismo" foi dada por uma pergunta de Jean Beaufret e pela publicação de $O$ existencialismo é um humanismo de Jean-Paul Sartre; ambos franceses e de uma geração posterior à dos alemães Heidegger, Cassirer e Scheler. ${ }^{51}$ Ou seja, a longa discussão realizada na Alemanha cruzou o Reno, chegou à geração seguinte e, em meados dos anos 1940, ecoava de modo muito significativo naquilo que Aubenque chama de "querela parisiense sobre o humanismo", um debate com vários desdobramentos, dentre os quais a famosa "morte do homem" com que Michel

48 "Chamamos de ontologia fundamental a analítica da essência finita do homem na medida em que ela prepara o fundamento de uma metafísica 'conforme à natureza do homem'. A ontologia fundamental não é outra coisa se não a metafísica do Dasein humano necessária para tornar possível a metafísica. Ela permanece fundamentalmente distinta de qualquer antropologia, mesmo a antropologia filosófica. Explicitar a ideia de uma ontologia do Dasein quer dizer o seguinte: mostrar que a analítica ontológica do Dasein, tal como foi caracterizada, responde a uma necessidade absoluta e, desta maneira, esclarecer sob qual perspectiva, de qual maneira, dentro de quais limites e em função de quais pressupostos ela coloca a questão concreta: o que é o homem?" Heidegger, Kant et le problème de la métaphysique, p.57 - grifos nossos

${ }^{49}$ A redação deste texto se estendeu por cerca de dez anos e tem uma história sombria e um tanto confusa. Segundo Victor Farias, ele foi escrito para ser publicado na revista do italiano Ernesto Grassi, epígono de Heidegger e intelectual simpático ao regime de Mussolini. O censor do governo alemão solicitou alterações ao texto por considerar que o humanismo nele defendido conflitava com o humanismo defendido pelo regime. No entanto, o texto finalmente publicado não considerava o pedido do censor e estava tal qual proposto por Heidegger; esta vitória do autor se deve, segundo Farias, a uma intervenção do embaixador Dino Alfieri junto a Goebbels a pedido do próprio Duce. Cf. Farias, Heidegger e o nazismo, pp. 236-46; Cf. tb. Aubenque, op. cit. pp.229-33

${ }^{50}$ Segundo Dana Villa, estas questões passam por outro caminho na obra de Heidegger, a saber, o curso sobre Schelling (1936), que foi antecedido por "Sobre a essência da verdade" e Sobre a essência da liberdade humana", ambos de 1930. (Cf. Villa, Arendt and Heidegger, pp.119-29.

${ }^{51}$ Dominique Janicaud apresenta e analisa com clareza e abundância a enorme e complexa influência que Heidegger exerceria na França já desde a publicação de Ser e tempo. Cf. JANICAUD, D - Heidegger en France. Paris: Albin Michel, 2001. 2 volumes. Cf. especialmente os quatro primeiros capítulos do primeiro volume. 
Foucault encerra As palavras e as coisas. ${ }^{52}$

Em sua conferência sobre o humanismo, Sartre afirma haver dois tipos diferentes de existencialismo, o cristão, do qual participam Karl Jaspers e Gabriel Marcel, e o ateu, do qual Heidegger e ele mesmo são parte. Afirma ainda que, apesar das diferenças, todos têm em comum "a estima de que a existência precede a essência, ou, se preferirem, que é necessário partir da subjetividade." ${ }^{53}$ Em sua resposta a Sartre, Heidegger se distancia precisamente neste ponto, de resto fundamental, alegando que, embora a afirmação de que a essência do homem é sua existência ocorra em Ser e tempo, ${ }^{54}$ ela nada tem a ver com aquilo de que fala Sartre, uma vez que este desconsidera a destruição da tradição ali realizada. Sartre teria se resumido a inverter a metafísica de Platão, segundo a qual a essência precede a existência, ao passo que Ser e tempo aponta para algo anterior à própria distinção entre esse essentiae e esse existentiae.

De acordo com a interpretação heideggeriana da alegoria da caverna, Platão alterou fundamentalmente o conceito grego de verdade ao submeter o desvelamento (alétheia) do ser à luz da ideia (ê̂dos). A antiga concepção de verdade como desvelamento apontava para o encontro entre o olho que vê e aquilo que é visto, de modo que a verdade se limitava à parcela do ser que se quis mostrar e à capacidade do olho de ver, pressupondo, portanto, um fundo ontológico oculto inesgotável. Esta concepção de verdade está presente na alegoria, mas Platão a submete a outra, que é a da visão da ideia subjacente ao ente visto, dando nascimento à separação clássica entre ser (essência) e aparecer (existência). Esta concepção de verdade permite a apreensão completa do ser subjacente ao ente visto porque a ideia é uma figura, uma forma, uma imagem captável de um só golpe pelo olho do espírito, para o qual nada permanece oculto, mas inteiramente dominado e dominável pelo intelecto. Por outro lado, estabelece-se uma distância intransponível entre o ver e o visto, de modo que se faz necessário pensar a relação entre o ser humano e o mundo sustentando-se na oposição entre sujeito e objeto; a metafísica do sujeito, que retira o homem do mundo e oferece em troca uma imagem do mundo — ou o mundo como representação — nasce aqui e está em plena

\footnotetext{
52 Greisch analisa deste ponto de vista, além de As palavras e as coisas, a conferência "Les fins de l'homme" de Jacques Derrida e o artigo "Humanisme et anarchie" de Lévinas, ambos de 1968 (Greisch, Qui sommes-nous?, pp.84-99). Louis Althusser afirma em seu último livro que sua interpretação de Marx foi também marcada pela "Carta sobre o humanismo". (Cf. Aubenque, "Du débat de Davos (1929)...", p.236)

${ }^{53}$ Sartre, L'existencialisme est un humanisme, p.26

${ }^{54}$ Heidegger indica ao menos três ocorrências, às páginas 117, 212 e 314 da primeira edição (numeração presente em várias edições, dentre as quais a aqui utilizada. Cf. Bibliografia), respectivamente $§ 25$, §43 e $§ 63$.
} 
operação quando Sartre afirma que o existencialismo equivale à tomada da subjetividade como ponto de partida.

Um dos resultados de tal operação é uma curiosa ambiguidade a respeito da dignidade do humano; por um lado, ele ganha primazia com relação ao ser e, por outro, é concebido como mais um ente entre os demais. Sua posição superior se assenta na exclusividade de que goza o intelecto no acesso às ideias e na produção de verdades baseadas em seu próprio funcionamento. Decorre disto a importância da formação (paideía) do homem, concebida por Platão como o desenvolvimento do olhar reto e bem posicionado capaz de conduzir à ideia, e pelos vários humanismos como meios para salvar a alma, desenvolver as forças criativas, aperfeiçoar a razão, despertar do senso comum, libertar o ser humano da necessidade. Apesar de sua superioridade, no entanto, o ser humano é também concebido como mais um ente entre os entes, uma vez que está agora inescapavelmente afastado do ser. Na concepção da verdade como desvelamento, o ser humano mantem uma relação íntima com o ser porque a verdade se dá no encontro entre o ver e o visto; o ser é apenas à medida que o humano o vê. Nesta concepção, o que diferencia o humano, não dos demais animais, mas dos demais entes, é precisamente este tomar parte do ser, esta capacidade de acolher a revelação do ser e constituir o mundo. No interior da metafísica do sujeito, no entanto, o ser humano se converte em um ente e, como todos os demais entes, é apartado do mundo, dotado de uma essência, apreensível sob a forma de uma ideia de homem, e de uma existência que a ela se opõe. Sartre se equivoca ao considerar que Heidegger "define" o humano afirmando que sua "essência é sua existência" porque a existência não é esta aparência que esconde uma essência, mas o colocar-se para fora de si mesmo necessário para o acolhimento do ser e para a constituição do mundo. É precisamente para enfatizar este caráter de externalização que Heidegger opta por grafar existência como "ek-sistência", de modo que, diferentemente da afirmação sartriana, "a essência do homem é sua ek-sistência" e esta não é conversível em nenhuma ideia do que é o humano. "Deste modo, o pensamento presente em Ser e tempo é contrário ao humanismo (...) porque este não coloca a humanidade do homem em um nível satisfatório." 55

55 Heidegger, "Carta sobre o humanismo", p.343. A posição de Sartre a respeito do humanismo e do sujeito é muito mais interessante do que esta breve passagem pode dar a entender. A conferência aqui referida é uma obra curta, de ocasião, e desagradou o próprio Sartre, que dedicou ao tema algumas de suas maiores obras, como $A$ transcendência do ego, O ser e o nada, Questão de método e A crítica da razão dialética. A este respeito, deve-se conferir também o segundo capítulo de La philosophie française entre la phénoménologie et la métaphysique (Paris: PUF, 1999) de Michel Haar, chamado "Sartre 


\section{Arendt e o debate sobre o humano}

O primeiro grande passo de Arendt na ampliação do problema do totalitarismo é profundamente marcado por todo este debate. Como era de se esperar, a aluna brilhante de Husserl, Heidegger e Jaspers se interessou pelas questões do debate alemão dos anos 1920 e, diante do embate entre a antropologia filosófica e a fenomenologia, manteve-se junto a esta. Isto significa, de saída, uma escolha pela filosofia, que se via então às voltas com o assédio da ciência para roubar-lhe os objetos de reflexão. Mais especificamente, a opção filosófica arendtiana a lança em uma investigação ontológica, o que a coloca ao lado de autores como Sartre e Merleau-Ponty e em oposição a autores como Adorno, que optou pela lógica. Prova disto, é que neste imediato pós-guerra, no mesmo período em que Sartre e Heidegger debatem sobre o humanismo, Arendt se ocupa também da filosofia da existência e escreve "O que é a filosofia da existência?" e "O existencialismo francês", ambos publicados em 1946, estreitamente vinculados entre si e com o debate acima esboçado. ${ }^{56}$ Estes textos diferem um tanto entre si no que se refere ao escopo e à extensão: "O que e a filosofia da existência?" tem a extensão de um capítulo de livro acadêmico, movimenta uma lista extensa de autores e pretende tanto mostrar as raízes comuns da corrente filosófica abordada quanto oferecer um panorama do pensamento dos dois principais autores da filosofia da existência; "O existencialismo francês", por sua vez, é mais curto e tem o objetivo aparentemente mais modesto de apresentar o existencialismo a um público mais amplo, mas termina indo além e apontando com precisão para duas linhas mestras subjacentes ao movimento. Apesar das diferenças, ambos são estreitamente unidos pela escolha de Arendt em organizar uma série de autores em função de um único problema fundamental, presente em todos estes autores e que animará parcela muito significativa de sua própria produção.

Em "O que é a filosofia da existência?", Arendt apresenta a filosofia "mais moderna" de então tomando como eixo o problema da unidade entre o ser e o pensamento. Esta escolha

contre Heidegger une défense aveugle de la métaphysique", além do último capítulo do volume da série The Cambridge Companion dedicado a Sartre, que traz uma extensa discussão a respeito da desconstrução do sujeito. (HOWELLS, C - "Conclusion: Sartre and the deconstruction of the subject" in: HOWELLS, C (ed.) - The Cambridge Companion to Sartre. Cambridge University Press, 1992, pp. 318-52

56 A conferência de Sartre que deu origem a $O$ existencialismo é um humanismo foi realizada na Sorbonne em outubro de 1945; o texto seria publicado em 1946, ano em que Heidegger elaborou sua resposta, publicada em 1947. Ambos os textos de Arendt foram reunidos por Jerome Kohn na coletânea Essays in Understanding (Cf. Bibliografia) [edição 
é perfeitamente justificável do ponto de vista dos conteúdos da filosofia da Existenz, mas é importante notarmos que ela revela também que estes temas a ocupam de modo mais agudo.

Como de costume, a explicação arendtiana volta a uma origem cronologicamente distante para revelar, com o auxílio do extenso arco temporal assim formado, o sentido de determinado desenvolvimento. Neste caso, o retorno deve ir até Descartes, responsável por um abalo importante na unidade entre pensamento e ser, mas incapaz de retirar a segurança do pensamento no interior do ser. Kant, por sua vez, destruiu inteiramente esta unidade ao estabelecer a distinção entre fenômeno e coisa-em-si, ao estabelecer que a essentia não estava mais de direito identificada à existentia, provando que "em qualquer proposição que afirma algo a respeito da realidade, vamos para além do conceito (a essentia) da coisa dada." ${ }^{57}$ Altera-se com isto o antigo conceito de ser e, no mesmo movimento, estabelece-se a autonomia completa do homem com relação ao ser circunscrevendo-a ao contexto (context) das leis exclusivamente humanas, à distância do contexto universal do ser, em que o homem é apenas uma coisa entre as outras. Em que pese a grandeza da empreitada kantiana, ela perfez apenas metade do caminho de destruição do conceito antigo de ser, pois deixou ainda intocada a ideia do ser como algo dado, como algo que, embora exterior ao homem, sempre o sujeitará de alguma maneira. Este resquício é especialmente visível no problema da liberdade.

\begin{abstract}
Para Kant, o homem tem a possibilidade de determinar suas próprias ações baseandose na liberdade de sua própria boa vontade. No entanto, as ações são elas mesmas sujeitas à lei natural da causalidade, uma esfera essencialmente alheia ao homem. Uma vez que um ato humano ultrapassa a esfera da subjetividade, que é a esfera da liberdade humana, ele entra na esfera objetiva, que é a da causalidade, e perde seu elemento de liberdade. (...) Esta liberdade não livre (unfree freedom) representa uma vez mais a estrutura antinômica do ser humano como situado no mundo. No momento preciso em que Kant transformou o homem no senhor e na medida do homem, ele também o fez escravo do ser. ${ }^{58}$
\end{abstract}

Este problema tem vida longa na filosofia posterior a Kant animando, por um lado, o esforço hegeliano de unir pensamento e ser sistematizando todo o movimento do espírito e, por outro, a resposta de Kierkegaard a Hegel por meio da afirmação do indivíduo como exceção ao sistema e da formulação dos conceitos de morte, sorte e culpa. Também Husserl se lança ao problema, pois elaborou uma fenomenologia que pretende realizar uma espécie de segunda criação ao reconstruir o mundo a partir da consciência e, assim, finalmente unir o homem ao mundo. Husserl não faz parte da filosofia da Existenz, mas seu método foi fundamental para ela por ter permitido pensar novamente o ser do homem separado de sua

brasileira: Compreender. São Paulo/Belo Horizonte: Cia das Letras/UFMG, 2008].

${ }^{57}$ Arendt, "What is Existential Philosophy?" p. 168 
história, de sua biologia ou de sua psicologia. Esta reconstrução do mundo a partir da consciência foi "a tentativa mais original e moderna de fornecer um novo fundamento intelectual para o humanismo. (...) Mas o que condena este humanismo moderno, esta expressão de boa vontade com relação à modéstia, é a desmedida (hubris) igualmente moderna que lhe subjaz e tem a esperança - secretamente, como em Hofmannsthal, ou aberta e ingenuamente, como em Husserl - de finalmente se tornar, por esta via discreta, aquilo que o homem não pode ser: o criador do mundo e de si mesmo." 59

Este longo movimento "alcançou, na Alemanha do pós-guerra, com os trabalhos de Scheler, Heidegger e Jaspers, uma clareza anteriormente inesperada ao articular as preocupações centrais da filosofia moderna." ${ }^{60}$ Embora Arendt cite Scheler ao lado de Heidegger e Jaspers, ela deixa de lado o expoente da antropologia filosófica e se concentra nos dois fenomenólogos. A leitura de Heidegger apresentada neste texto é particularmente marcada pela situação histórica e pessoal mais imediata, o que exige um comentário de ordem biográfica.

Segundo Jacques Taminiaux, as relações entre Arendt e Heidegger devem ser divididas em três fases distintas; há, de início, uma fascinação esmagadora, seguida de enorme amargura e, por fim, uma superação de ambas. Este texto sobre a filosofia da existência constitui toda a segunda fase nesta divisão. Escrevendo em 1946 (na Alemanha, o texto foi publicado em 1948), Arendt inclui uma nota informando ou relembrando a adesão de Heidegger ao nazismo, afirmando que ele teria proibido a entrada de Husserl na universidade (o que era então apenas rumor e, ao que parece, permanece não confirmado). ${ }^{61}$ Neste mesmo ano, aliás, em um encontro com Sartre em Nova Iorque, Arendt perguntou sobre Heidegger e ouviu que, depois da derrota alemã, Heidegger teria escrito a um professor da Sorbonne lamentando o "mal entendido" entre a França e a Alemanha e solicitando uma "entente" acadêmica franco-alemã. Pouco mais tarde, o próprio Sartre receberia uma carta de Heidegger. Arendt não tardou a relatar a Jaspers, com quem partilhou ao longo dos anos muito das angústias de admirar e amar Martin. ${ }^{62}$

\footnotetext{
${ }^{58}$ Arendt, "What is Existential Philosophy?", p. 171

${ }^{59}$ Arendt, "What is Existential Philosophy?", pp.165 e 166-7

${ }^{60}$ Arendt, "What is Existential Philosophy?", p.163

61 Safranski afirma se tratar de um "boato incorreto". Cf. Heidegger: um mestre da Alemanha entre o bem e o mal, p. 307; apesar de seus defeitos, deve-se conferir também Faye, Heidegger: a introdução do nazismo na filosofia, p.105-8.

62 Cf. Grunenberg, Hannah Arendt et Martin Heidegger, pp. 290-5; Young-Bruhel, For the
} 
Ao longo do texto, Arendt reconhece a importância da filosofia de Heidegger, mas não se furta a afirmar que é ela marcada por uma "fachada terminológica", por "sofismas" e por "truques verbais". Os atos políticos de Heidegger são vinculados ao estado abissal do pensamento político nas universidades alemãs, marcado pela falta de responsabilidade e por uma característica frivolidade espiritual (spiritual playfulness) presentes desde o romantismo alemão - "Heidegger é de fato (esperamos!) o último romântico." 63

Muito desta amargura e desta recusa da figura de Martin transbordam para a leitura feita por Arendt do pensamento de Heidegger neste ensaio, que difere muito, tanto no tom quanto na interpretação, daquilo que Arendt escreverá a respeito de Heidegger em outras ocasiões. É difícil precisar exatamente o momento desta mudança, mas Grunenberg nos mostra que ela é certamente anterior a 1955. Calvi Schrag, um doutorando que, sob orientação de Paul Tillich, fazia uma tese sobre a analítica do Dasein em Heidegger, escrevera a Arendt algumas perguntas a respeito de Heidegger baseadas neste texto sobre a filosofia da existência. Em uma carta datada de 31 de dezembro de 1955, Arendt responde: "Eu devo te fazer uma alerta contra este meu ensaio sobre o existencialismo, especialmente na parte dele que se refere a Heidegger. Ela não é apenas inadequada, mas em alguns pontos é simplesmente falsa. Peço que esqueça este ensaio." ${ }^{64}$ É provável que o primeiro reencontro dos dois, em 1950, em Freiburg, tenha um peso forte na mudança de posição de Arendt — na "inversão da imagem de Heidegger" (Grunenberg) —, uma vez que foi a partir de seu retorno desta viagem que ela, desde a primeira hora muito dedicada à publicação das obras de Jaspers nos EUA, passou a dedicar o mesmo esforço também para as obras de Heidegger.

A interpretação de Heidegger neste ensaio amargurado se concentra em uma parte do texto intitulada "O self como ser e nada: Heidegger", indicando já de saída certa mistura deliberada com o pensamento de Sartre precisamente no ponto da relação entre o homem e o mundo. A interpretação conduz à afirmação de que, se todas as ações humanas ganham seu sentido em função da morte e esta é a mais solitária das experiências, o Dasein é a realização completa do solipsismo do homem contra o mundo circundante. Deste self inteiramente isolado surge a constante criação do mundo tendo o nada como fonte de sentido. Assim,

Love of the World, pp. 214-20; Carta de Arendt a Jaspers de 9 de julho de 1946.

${ }^{63}$ Arendt, "What is Existential Philosophy?", p.187. O tema da frivolidade espiritual perpassa toda a biografia que Arendt dedicou a Rahel Varnhagen e é desenvolvida em Origens do totalitarismo, pp.165-70.

${ }^{64}$ Grunenberg, Hannah Arendt et Martin Heidegger, p. 294. Cf. tb. Young-Bruhel, For the 
Heidegger coloca de duas maneiras distintas o ser humano no lugar tradicionalmente ocupado por Deus; por um lado, ele é o único ser em que existência e essência coincidem e, além disto, é o responsável pela criação do mundo ex nihilo. Assim como Deus, o homem é o "senhor do ser" e o domina. Esta interpretação enviesada atribui ainda a Heidegger um estranho funcionalismo que seria similar ao realismo de Hobbes, uma vez que ambos propõem um modelo de ser humano que funcionaria melhor em um mundo pré-ordenado, portanto livre de espontaneidade.

Jaspers aparece na sequência descrito de modo quase espelhado ao de Heidegger, a começar pelo tom muito favorável que permeia toda esta parte do texto. Jaspers também resulta dos desenvolvimentos que vão de Kant a Husserl, mas, ao invés de pensar a essência do humano encerrada em si mesma e escondida das aparências, a filosofia de Jaspers enfatiza a comunicação e o aparecer como elementos estritamente humanos. Diferentemente de Heidegger, que, se não romper com sua própria filosofia, já terá encerrado sua contribuição, ${ }^{65}$ Jaspers ainda está em pleno desenvolvimento e tem ainda muito a contribuir ao pensamento contemporâneo porque, com ele, "a filosofia da existência emergiu de seu período de preocupação com o self."66

Sartre e Camus aparecem neste texto, mas apenas incidentalmente, como desenvolvimentos da filosofia da existência, em especial na versão heideggeriana. Eles são, no entanto, o tema do texto dedicado ao "Existencialismo francês" elaborado no mesmo período. Embora este seja um texto de divulgação e ofereça, portanto, certos limites à análise, sua estratégia argumentativa é importante aqui porque revela os temas de maior interesse para Arendt no existencialismo. A explicação da então novíssima filosofia se dá a partir da afirmação de que o existencialismo representa uma rebelião de intelectuais organizada em duas linhas fundamentais: o repúdio firme ao esprit sérieux e a recusa em aceitar o mundo dado como o lugar natural e predestinado do ser humano. O problema do esprit sérieux aponta para o conflito entre as demandas da sociedade e a "alma" de cada indivíduo. O homem "sério" concebe-se a si mesmo como chefe de família, empresário, acadêmico, religioso e toma para si as exigências destas posições sociais como se fossem naturais, como se fossem sua essência. No entanto, como, "em seu coração, todo mundo sabe

Love of the World, pp.217-20.

${ }^{65}$ Arendt, "What is Existential Philosophy", p. 182

66 Dana Villa oferece uma leitura crítica da interpretação arendtiana da filosofia de Heidegger contida neste ensaio. Cf. Villa, "The Anxiety of Influence: On Arendt's Relatioship to Heidegger" 
suficientemente bem que não é idêntico à sua função, l'esprit sérieux também indica má-fé no sentido de fingimento." ${ }^{67}$. A segunda grande linha da revolta existencialista se manifesta na "insistência sobre a carência fundamental de um lar para o homem no mundo", ${ }^{6}$ sobre o descompasso, ou mesmo a incompatibilidade entre o homem e o mundo. Para Camus, o fato de o homem e o mundo estarem juntos, ou melhor, de o homem ser lançado para viver no mundo é inteiramente absurdo; para Sartre, o absurdo está tanto na existência do homem quando na existência do mundo. Embora sigam caminhos diferentes para pensar o absurdo Camus se engaja em uma filosofia do absurdo; Sartre, em "uma nova filosofia positiva, talvez até mesmo em um novo humanismo"69 - ambos são conduzidos ao problema da ação e da liberdade humanas.

Estas duas linhas fundamentais apontam tanto para o essencialmente indeterminado inscrito no humano quanto para sua relação de estranhamento com o mundo, ou seja, para a questão da identidade entre o pensamento e o ser, indicada por Arendt como o problema fundamental deixado por Kant e que, via Kierkegaard, Nietzsche e Husserl, marcou profundamente a filosofia da existência de Heidegger e Jaspers, e o existencialismo de Sartre e Camus. Este problema fundamental ganha termos e tons distintos em cada um destes autores - em Kant, ele aparece como o problema da liberdade não livre; em Kierkegaard, como o lugar do indivíduo no interior do sistema hegeliano; em Scheler, como o lugar do homem no cosmos; em Heidegger, como o ser-aí-no-mundo; em Sartre, como o ser e o nada. Importa pouco em nosso contexto analisar ou julgar a correção das interpretações e análises feitas por ela. O decisivo aqui é notar que a preocupação filosófica de Arendt a conduz a estes autores e, além disto, dentre os vários caminhos possíveis de leitura, ao problema da identidade entre pensamento e ser. Este horizonte de questões, presente no percurso de Arendt desde seus anos universitários até o desenvolvimento de seu pensamento maduro, se apresenta em A condição humana organizado a partir do evento totalitário.

\footnotetext{
${ }^{67}$ Arendt, "French Existencialism", p. 189-90

${ }^{68}$ Arendt, "French Existencialism", p. 191

${ }^{69}$ Arendt, "French Existencialism", p. 192
} 


\section{Parte II: Differentia specifica, um elemento totalitário da tradição}

A centralidade do problema do humano no pensamento de Arendt é, portanto, herdada das discussões realizadas em seus anos de formação. Como acabamos de ver, ele também organiza a leitura dos autores seus contemporâneos revelando que esta é uma preocupação fundamental da autora de A condição humana. Lendo atentamente certos textos elaborados no período imediatamente seguinte à publicação de Origens do totalitarismo, ou seja, no período em que os projetos de pesquisa sobre Marx foram elaborados, perceberemos que a questão do humano informa também a leitura dos grandes filósofos políticos da tradição feita por Arendt neste período. Este debate alemão e posteriormente também francês está na base da suspeita mantida por Arendt contra a tradição e amplamente confirmada ao longo de sua releitura dos grandes autores. Ao menos neste momento, de resto fundamental, sua contribuição para o "desmantelamento da metafísica" se dará ao redor da questão do humano, pois é através dela que Arendt realiza, por um lado, a destruição da tradição e, por outro, a construção de um novo pensar político a partir de A condição humana.

\section{Hannah Arendt e Martin Heidegger}

Neste ponto, a influência de Heidegger sobre Arendt se mostra particularmente aguda, o que exige um excurso. Como se sabe, Hannah Arendt e Martin Heidegger tiveram uma relação muito mais próxima do que a de professor e aluna; eles se amaram profundamente desde seu encontro até o fim de suas vidas. ${ }^{70}$ A história do amor entre um professor famoso, casado, pai de dois filhos e uma brilhante aluna, posto à prova pelos acontecimentos históricos mais sérios do século XX oferece um roteiro muito adequado à imaginação, como prova a existência de uma série de romances e peças de teatro, de qualidade muito variável,

${ }^{70}$ Edna Brocke, sobrinha de Arendt, descreveu assim o último encontro que teve com sua tia, alguns meses antes da "Grande Hannah" falecer: "Nosso último encontro aconteceu em 1975. Ela chegara em Marbach para examinar e organizar os papéis de Karl Jaspers no Arquivo literário alemão. Nós a visitamos e ouvimos na última noite como se um Profeta da Bíblia Hebráica estivesse falando conosco. Somente depois nós compreendemos que seu intenso sumário das mais diversas experiências e percepções tinha sido uma prestação de contas. Na manhã de 5 de julho, nós a levamos à estação de trem. Ela estava de partida para um encontro com Heidegger. Ao nos despedirmos dela sobre a plataforma, eu sussurrei uma questão para ela: 'Você tem que ir?'. A resposta ainda ressoa em meu ouvido: 'Fröschlein, algumas coisas são mais fortes que um ser humano."' (Brocke, E "'Grande Hannah' - minha tia". in: Arendt, Escritos Judaicos, p.825) Cf. tb. Grunenberg, Hannah Arendt et Martin Heidegger; Safranski, Heidegger: um mestre da Alemanha entre o bem e o mal, pp.163-83. 
dedicados a esta história. Isto não seria um problema não fosse a excessiva facilidade com que este roteiro se insinua nas interpretações das obras dos autores, em especial na de Hannah Arendt. Não existe, evidentemente, separação completa entre vida e obra (ou, para falar com Nietzsche: "... rimos quando encontramos 'homem e mundo' colocados lado a lado, separados pela sublime pretensão da palavrinha 'e'!"). ${ }^{71}$ Mas estas esferas distintas, irredutíveis uma à outra, são frequentemente confundidas seguindo o apelo imaginativo do excelente roteiro oferecido pela história de Hannah e Martin.

Como dissemos acima, é uma felicidade que os estudos arendtianos tenham sido fundados, por assim dizer, pela biografia de Young-Bruhel; o inverso pode ser dito dos estudos sobre a relação entre Arendt e Heidegger, que tiveram no livro de Elzbietta Ettinger sua primeira publicação mais extensa. Baseando-se na correspondência então inédita entre os dois, ${ }^{72}$ Ettinger lança uma série de afirmações, suposições e ilações que não encontram suporte suficiente nas cartas e ainda formam certa imagem de uma Arendt inteiramente dependente da sombra do homem que ama. Esta dependência extrapola muito facilmente a relação íntima dos dois, sobretudo através da intenção de dedicar a Martin $A$ condição humana, livro que "surgiu diretamente dos primeiros dias em Freiburg e deve a você quase tudo em todos os sentidos."73 Desdobrando afirmações íntimas como esta, Ettinger, professora do MIT, conferiu seriedade à tese de que a obra de Arendt "deve tudo" a Heidegger porque Hannah devia tudo a Martin. Além do evidente psicologismo barato e do sentimentalismo kitsch, deve-se notar também a presença de um sexismo difuso, visível tanto na tese quanto na escolha de tratar Hannah Arendt por Hannah e Martin Heidegger por Heidegger ao longo de todo o livro (pelo menos na edição brasileira). O padrão se estende aos respectivos cônjuges; Heinrich Blücher é sempre Blücher, Efride Heidegger, Elfride. No caso desta última, é possível argumentar que se trata de recurso justificável pelo fato de Martin ter uma obra e Elfride não, e que o fato de ela usar o sobrenome famoso do marido obriga o texto a se servir do primeiro nome dela. Mas isto definitivamente não se aplica ao

\footnotetext{
${ }^{71}$ Nietzsche, A gaia ciência, §346 (tradução de Rubens Rodrigues Torres Filho)

72 Há um quiprocó jurídico e midiático em torno desta correspondência e relatado por Benhabib. Ettinger foi a primeira a ter acesso às cartas - anteriormente negado à própria Benhabib - e, a fim de dar visibilidade ao livro que estava escrevendo, deu uma entrevista ao Frankfurter Allgemeneine Zeitung; Safranski elaborava então sua biografia sobre Heidegger e se serviu da entrevista em seu livro, o que lhe rendeu um processo judicial da parte de Ettinger. Este foi o estado de coisas levou o filho de Heidegger a publicar os inéditos do pai. "Devemos, portanto, a publicação desta correspondência a uma combinação entre curiosidade voyeurística, oportunismo intelectual e escândalo no meio cultural." (Benhabib, The Reluctant Modernism of Hannah Arendt, p.225)
} 
casal Arendt e Blücher, tanto porque os sobrenomes são distintos quanto porque a grande obra do casal foi escrita por ela, não por ele (ainda que Blücher tenha trabalho intelectual respeitável e tenha exercido influências sobre a obra de Arendt). Este procedimento não encontra absolutamente qualquer justificativa no que diz respeito a Arendt e Heidegger. Talvez se pudesse usar a diferença como um recurso expressivo útil para retratar o período da vida em que Arendt era uma jovem aluna e Heidegger já um professor famoso. A extensão do procedimento por todo o livro, no entanto, nos faz concluir que a razão desta diferença não tem motivos literários.

Esta centralidade do amor entre Hannah e Martin aparece também no trabalho de Richard Wolin, embora este seja efetivamente mais sério que o de Ettinger. Wolin é crítico acerbo de Heidegger desde pelo menos The Politics of Being, livro dedicado a mostrar a indissociabilidade entre a obra heideggeriana e o engajamento político de seu autor. Em um livro seguinte, Heidegger's Children, Wolin une Hannah Arendt, Karl Löwith, Hans Jonas e Herbert Marcuse sob uma única rubrica, "filhos de Heidegger", porque, além de alunos de Heidegger, todos eles eram judeus assimilados, foram "heideggerianos convictos" ao menos por certo tempo e tiveram que lidar com a "virada totalitária" do mestre; ou melhor, do pai. De acordo com a tese de Wolin, a condição de judeus assimilados os aproximava do Geist afastando-os da Torá, e Heidegger representava para eles, não apenas a encarnação da Kultur que os definia, mas também o meio para a realização da Bildung que consistia em uma maneira de afirmação de si sem grandes contradições com sua condição judaica até meados dos anos 1920, quando a sociedade alemã os forçou a se reconhecerem como judeus opondose a eles enquanto alemães. Em certo momento deste processo, Heidegger passou para o outro lado deixando órfãs as quatro crianças, agora forçadas a romper internamente com o pai. No entender de Wolin, o rompimento não foi completo, pois "todos aceitaram, de um modo ou de outro, uma série de preconceitos profundos contra a natureza da modernidade política - democracia, liberalismo, direitos individuais e assim por diante - tornando muito difícil articular um ponto de vista teórico significativo no mundo do pós-guerra. ${ }^{74}$ Wolin concede que as crianças se afastaram do pai em muitos pontos, mas afirma que mantém fundamentalmente o diagnóstico do tempo feito por Heidegger estendendo assim a influência deste como Zivilisationskritiker, crítico da civilização.

No caso específico de Hannah Arendt, a filiação se expressa em três pontos. O

${ }^{73}$ Carta de Arendt a Heidegger de 28 de outubro de 1960

${ }^{74}$ Wolin, Heidegger's Children, p.8 - a passagem inteira está grifada no original 
primeiro é a recusa de reconhecer a especificidade alemã no surgimento do nazismo, esforço dedicado à salvaguarda da Kultur que lhe era tão cara. "Ao enfatizar os elementos 'universais' da Solução Final às expensas de suas qualidades especificamente alemãs, ela [Arendt] também conseguiu evitar a implicação de seu país de origem — e, desta forma, narcisisticamente, a própria implicação. ${ }^{75} \mathrm{O}$ segundo ponto é a ausência de pensamento (thoughtlessness) atribuída por Arendt a Eichmann e, por extensão, à civilização moderna, concebida em termos de "queda", portanto aparentada à crítica heideggeriana ao das Man. Por fim, e vinculada a este ponto, a terceira expressão da filiação se situa em certa inveja da polis, concebida por Arendt como momento originário e fulgurante, diante do qual a contemporaneidade aparece como opaca e desinteressante. Cada uma destas três afirmações é equivocada à sua maneira, a começar pelo peso excessivo dado à psicologia e à sociologia da autora na leitura da obra; os dois últimos pontos exigiriam uma resposta mais extensa, que nos levaria para longe de nossa preocupação central aqui, mas o primeiro será tematizado ao longo do presente estudo. O que importa notar neste momento é a manutenção da menoridade de Arendt com relação a Heidegger e as limitações impostas a ela por algumas formas de amor. Embora Wolin evite o caminho de Ettinger e não leve longe demais a história do romance, ele explica a relação com base em uma forma de amor ao pai e à pátria espirituais (Heidegger e Kultur) e a si mesma ("narcisisticamente"), do que resulta a consideração de que a obra de Arendt, por mais méritos que tenha, é marcada por estas limitações impostas por este tipo de amor que lhe negam a maioridade intelectual (Como este mesmo tipo de limitação é identificada por Wolin também nos demais "filhos" e eles são todos homens, não há sexismo envolvido aqui).

Em direção contrária, André Duarte defende a estatura intelectual de Arendt afirmando que sua relação para com Heidegger não deve ser descrita em termos de dependência intelectual, mas de uma proximidade na distância, ${ }^{76}$ formulação encontrada em uma carta de Martin para Hannah e relevante para discussões a respeito de um conceito de amor em Heidegger. ${ }^{77} \mathrm{O}$ ponto de partida desta leitura oferece uma série de bons insights ao intérprete, ${ }^{78}$ mas traz consigo o inconveniente de recorrer a um afeto e a um momento íntimo

\footnotetext{
${ }^{75}$ Wolin, Heidegger's Children, p.61

${ }^{76}$ Cf. Duarte, "Arendt e a modernidade: proximidade na distância em relação a Heidegger" e "Proximidade e distância entre Arendt e Heidegger" in. O pensamento à sombra da ruptura, pp. 319-41.

77 Cf. Arendt-Heidegger - correspondência, carta de 21.02.1925; cf. tb. Grunenberg, Hannah Arendt et Martin Heidegger: histoire d'un amour, pp. 102-3.

${ }^{78}$ Além dos textos de Duarte e o livro de Grunenberg, cf. tb. Agamben \& Piazza, L'ombre de
} 
para tratar das relações entre os dois grandes filósofos, o que termina por aproximar Duarte da interpretação contra a qual se coloca. Posto que o objetivo de Duarte é se contrapor à tese da menoridade de Arendt, a leitura é insuspeita de sexismo e, mais do que isto, chega a correr os riscos opostos àqueles trazidos pela leitura de Wolin, pois há uma grande ênfase nas distâncias, na recusa das dependências hierárquicas contrárias à autonomia do pensamento e uma tendência a não dar o peso devido às proximidades. Uma consequência deste acento sobre as distâncias é a afirmação de que a tese da menoridade de Arendt está pressuposta também nas interpretações oferecidas por Villa, Taminiaux e Benhabib, apesar de estes afirmarem claramente o contrário.

Como já se indicou acima, Taminiaux esquematiza a relação entre Arendt e Heidegger em três fases: fascinação, amargura e superação (dépassement). Esta terceira fase, em que as distâncias ganham centralidade, se anuncia já à época da redação de $A$ condição humana, de modo que a fase superação se expressa na maior parte da obra publicada por Arendt. Villa, por sua vez, lista três temas heideggerianos presentes em A condição humana — pensar a relação entre o homem e o mundo em contraposição à relação sujeito e objeto; a vontade de potência como subjacente à visão tradicional de liberdade como soberania e de ação como atividade orientada a fins; patologias da modernidade — e afirma em seguida: "Estes três temas constituem aquilo que A condição humana deve positivamente a Heidegger. Mas o que tornou o livro um clássico não é sua reformulação em língua acessível das abstrusas noções de Heidegger. Sua originalidade inaugural é evidente na maneira que Arendt usa as ideias de Heidegger contra Heidegger, a serviço de ideias que ele teria condenado. A subversão arendtiana do pensamento de Heidegger é exatamente tão profunda quanto sua dívida filosófica para com ele." ${ }^{79}$ Benhabib, por fim, afirma que Heidegger permaneceu em silêncio com relação à obra de Arendt - mais especificamente A condição humana "porque reconheceu o quanto sua antiga aluna subverteu as premissas fundamentais de sua ontologia; e ela havia feito isto no interior de um enquadramento (framework) que ainda mantinha profundas marcas de seu pensamento." 80 Estes três trechos se inserem em interpretações distintas entre si e com finalidades próprias, mas mostram uma convergência dos três intérpretes quanto à afirmação da autonomia intelectual de Arendt. Percebe-se ademais que os três intérpretes pensam efetivamente em termos de proximidades e distâncias expressas em termos como diálogo (Benhabib), influência (Villa) ou, mais espirituosamente, 
ironia (Taminiaux), o que mostra a recusa consciente da ideia segundo a qual Arendt cabe na sombra de Heidegger.

Com a exceção da formulação de Benhabib, estas afirmações trazem ainda a vantagem de se afastar bastante da relação pessoal entre Hannah e Martin centrando-se mais na obra deixada por eles. A fim de qualificar a proximidade mais essencial entre Arendt e Heidegger, Villa afirma que Arendt "se volta para a desconstrução [heideggeriana] da filosofia ocidental a fim de revelar (uncover) as origens dos preconceitos desta tradição contra a política. Arendt não se limita a repetir o gesto 'destrutivo' de Heidegger: ela leva sua violência interpretativa para uma direção que ele não reconheceria (e aparentemente não reconheceu)." ${ }^{11} \mathrm{Na}$ mesma linha, tratando do esforço arendtiano de destruir os traços platônicos da tradição a fim de expor as "articulações fenomênicas da vita activa", Taminiaux afirma o seguinte: "Por estes três traços — desconstrução, memória e olhar atual — não há dúvida a meu ver de que este procedimento (démarche) fenomenológico aparenta em seu estilo ao que Martin Heidegger conduziu na época de Marburg. Em seu estilo, mas definitivamente não em seu conteúdo." 82 Ambos concordam, portanto, que Heidegger exerce uma influência sobre a "forma" do pensamento de Arendt, uma vez que esta influência é vista no "gesto", no procedimento e no estilo; a autonomia da autora se situa no "conteúdo" e na direção atribuídas a sua obra. Na mesma linha destes comentadores, parece possível apontar para a relação entre Arendt e Heidegger a partir de ponto de vista diferente, que traz a vantagem de contornar a artificialidade da distinção entre forma e conteúdo — da qual Taminiaux e Villa estão cientes, diga-se.

Como se sabe, no livro IV de sua Metafísica, Aristóteles chamou de filosofia primeira a mais geral e mais fundamental preocupação filosófica, a saber, aquela que se lança ao problema do ser enquanto ser. Heidegger se ocupa da questão do ser em seu sentido mais geral e mais fundamental desde a primeira seção de Ser e tempo, obra que, como se sabe, traz a elaboração de uma ontologia fundamental. Uma das principais características deste tipo de reflexão é se dar na mais ampla generalidade, donde ser chamada de primeira. Arendt jamais realizou qualquer esforço de fazer filosofia primeira e, como veremos à frente, "o gesto, o procedimento e o estilo" se apoiam na ontologia fundamental heideggeriana. No entanto, os afastamentos de Arendt começam a aparecer, com firmeza e clareza, tão logo saímos deste âmbito generalíssimo. Por exemplo, na analítica do Dasein, o humano aparece como ser

${ }^{80}$ Benhabib, The Reluctant Modernism of Hannah Arendt, p.104.

${ }^{81}$ Villa, Arendt and Heidegger, p.xi - grifo no original 
orientado para a morte, contra o que Arendt estabelece a centralidade do nascimento. Ou seja, naquilo que se refere à máxima generalidade do pensamento heideggeriano, a ontologia fundamental, Arendt permanece junto a ele; no primeiríssimo passo para fora desta generalidade máxima, Arendt já diverge dele. Isto não quer dizer que Arendt discorde de todo o resto, mas significa que sua autonomia lhe permitiu chegar a este nível de discordância, algo que simples epígonos não são capazes de fazer. É verdade que as relações entre Arendt e Heidegger se dão em direção única, ou seja, que a reflexão arendtiana é profundamente marcada pelo pensamento de Heidegger, mas este não parece ter sido minimamente afetado por ela. Ela expressou se débito a ele afirmando seu vínculo à linhagem de que ele participa, citando-o como interlocutor direto em $A$ vida do espírito, ${ }^{83}$ ao passo que ele só responde por cartas. Sem negar que a personalidade de Hannah e do melindroso Martin tenham algum papel nesta verticalidade, a melhor explicação para ela parece ser aquela que se baseia na obra dos dois e percebe que Arendt não se ocupou de filosofia primeira e que esta constitui a quase totalidade da obra de Heidegger. Confundir esta diferença com a diferença entre filósofos maiores e menores é um equívoco que, se levado às últimas consequências, nos forçaria a concluir que Marx é menor porque se serviu da dialética de Hegel; Espinosa, porque se serviu da razão de Descartes; Aristóteles, porque se serviu da Ideia de Platão.

Um dos traços que marcam as proximidades entre Arendt e Heidegger é visível na problematização da relação que eles mantêm com os grandes autores do passado. Por razões distintas e referindo-se a objetos distintos, Arendt e Heidegger partilham a consideração de que se estão separados da tradição (Arendt) e da metafísica (Heidegger) e, consequentemente, incumbem-se da tarefa de desmontar e destruir a herança que lhes foi entregue. As respectivas tarefas se expressam na afirmação arendtiana de que ela pretende se afastar da "hostilidade da filosofia contra a política" 84 e no declarado esforço heideggeriano, seja de recolocar a mais fundamental das questões, seja de oferecer uma alternativa à "interpretação técnica do pensar". ${ }^{85} \mathrm{Em}$ ambos os casos, a estratégia adotada é a dissolução de determinado arranjo teórico formulado por Platão e Aristóteles e responsável por certa característica inicial

82 Taminiaux, La fille de la Thrace et le penseur professionnel, p. 41.

${ }^{83} \mathrm{Cf}$. Arendt, The Life of the Mind - Thinking, p.212; "Heidegger's Will-not-to-will" em The Life of the Mind; "Heidegger faz oitenta anos" em Homens em tempos sombrios; "Concern with Politics in Recent European Philosophical Thought" em Essays in Understanding. ${ }^{84}$ Cf. supra p.30.

85 Pelo menos à primeira vista, a abordagem aqui proposta pode prescindir da distinção entre o pensamento heideggeriano pré e pós Kehre, donde a possibilidade de abordar Ser e tempo e "Carta sobre humanismo" sem muita diferenciação. 
que persistiu ao longo de todo o pensamento que os teve como origem. Assim, é verdade que, diferentemente de Heidegger, "Arendt não concebeu a história do Ocidente em termos da 'história do Ser', (...) manteve uma distância crítica em relação à tese da Seinsgeschichte heideggeriana (...) e jamais desesperou do engajamento político e da capacidade humana de trazer a novidade à luz do dia." ${ }^{86}$ No entanto, em que pesem estas diferenças de "conteúdo", não se pode deixar de considerar que ela concebeu a história da tradição dentro de uma estrutura muito semelhante à da Seinsgeschichte e isto tem consequências de grande relevância para sua obra.

Uma consequência particularmente evidente e incômoda desta estratégia de ir à origem para procurar o ponto problemático de todo pensamento filosófico ocidental é a introdução de certo caráter megalomaníaco às tarefas, que tendem a fazer tábula rasa de milênios de pensamento desconsiderando diferenças gigantescas no interior deste longuíssimo período. ${ }^{87} \mathrm{O}$ eterno problema da leitura de filósofos feita por outros filósofos, sempre marcada por distorções, adaptações, traições e alterações, ganha aqui contornos específicos, pois estamos diante de um recorte — se é que este termo é possível aqui — amplo o suficiente para incluir virtualmente todo o pensamento ocidental. O intérprete se vê, assim, diante de dois caminhos possíveis: ele pode aceitar a diluição dos mais distintos autores no interior desta longa história proposta por Arendt e Heidegger ou, ao contrário, negar inteiramente esta mesma diluição mostrando suas dificuldades. Embora estes movimentos não sejam excludentes e se complementem em vários pontos, os limites da presente tese impõem a necessidade de optar pelo primeiro caminho compreendendo o projeto de Arendt (e o de Heidegger parcialmente) a partir de seus próprios argumentos e da coerência interna a sua obra. O estudo das distorções, alterações e adaptações feitas por

${ }^{86}$ Duarte, O pensamento à sombra da ruptura, p.87

87 Curiosamente os leitores, estudiosos e críticos de Arendt não costumam se debruçar sobre a criação de uma rubrica destinada a juntar e em larga medida anular pensadores tão diferentes quanto, por exemplo, Aristóteles, Hobbes, Espinosa, Hume e Gramsci (um marxista). É fato que ela apresenta, bastante en passant, uma nuance ao afirmar que Cicero, Maquiavel, Montesquieu e Tocqueville estão fora da tradição e são autênticos "pensadores políticos", além de conferir a Kant um lugar particular. A proposta, entretanto, ainda que assim bemolizada, conduz ao problemático descuido de diferenças inconciliáveis e - por que não? - à identificação de filósofos que estariam em profunda sintonia com seu próprio pensamento. Quanto a Heidegger, deve-se notar ao menos a afirmação de Hervé Pasqua, para quem a diferença ontológica já havia sido discutida pelos pensadores árabes, em especial Alkindi, Alfarabi e Avicena, e mais tarde retomada por Tomas de Aquino e Duns Scotus. Em sua argumentação, Pasqua se refere a Étienne Gilson - um autor caro a Arendt, diga-se. (Cf. GILSON, Les Constantes philosophiques de l'être. Paris: Vrin, 1983. p. 204. Apud PASQUA, H - Introdução à leitura do "Ser e tempo" de Martin Heidegger). 
Arendt em sua leitura de "filósofos tradicionais", bem como de eventuais proximidades entre ela e estes mesmos autores, fica para outra ocasião.

Apesar desta evidente desvantagem, no entanto, esta estratégia de ir à origem da tradição ou da metafísica oferece, por outro lado, a vantagem proporcional de mostrar afinidades profundas entre modos, temas e problemas caros a virtualmente todos os grandes filósofos. O recorte amplíssimo se mostra muito frutífero porque expõe estas afinidades tenazes facilitando a tarefa de desmantelar a tradição, necessária tanto para a elaboração da crítica profunda ao totalitarismo quanto para o ressurgimento da "questão do sentido do ser". Assim, sem recair no temerário esforço de apresentar e desenvolver aqui todos os vínculos entre Arendt e Heidegger, indiquemos um ponto particularmente profundo em que eles se tocam, que é crucial para as tarefas de ambos e que parece não ter recebido a atenção merecida por parte dos estudiosos.

O "gesto destruidor" e a "démarche fenomenológica" que assemelham Arendt e Heidegger talvez se façam especialmente visíveis se adotarmos como ponto de partida a crítica de ambos à differentia specifica. Todo leitor atento de Ser e tempo sabe que o problema da differentia specifica foi claramente tematizado e elaborado por Heidegger; menos evidente, entretanto, é a relação de Arendt com este problema. A crítica à differentia specifica não é tematizada de modo direto na obra publicada por ela, de modo que é necessário recorrer aos cursos dedicados à filosofia de Marx no contexto de sua pesquisa sobre os elementos totalitários no marxismo. Como vimos acima, Arendt lida, a partir de 1952, com a antiga suspeita de que Marx e a tradição desempenharam algum papel no surgimento do totalitarismo e realiza uma "mudança de registro" aparentemente inexplicável, passando de "um livro sobre política" (Origens do totalitarismo) a um "livro sobre de filosofia fundamental" (A condição humana). A crítica à differentia specifica desempenha aqui um papel fundamental porque permite indicar de modo preciso um dos elementos totalitários da tradição, do que resulta o aprofundamento da luta contra o totalitarismo. Vejamos, portanto, o início e o fim da tradição servindo-nos principalmente de "Tradição e era moderna", texto de 1954 em que encontramos uma caracterização da tradição enfatizando seu fim. ${ }^{88}$

${ }^{88}$ Seria possível também nos servirmos de "Filosofia e política", texto resultante de uma série de aulas (lectures) dadas por Arendt em 1954, em que o início da tradição ganha ênfase. Arendt jamais publicou este texto, que veio a público pela primeira vez em 1990 ("Philosophy and Politics" in. Social Research, volume 57, no.1, Spring 1990) editado por Jerome Kohn, que reeditou o mesmo texto sob o título de "Sócrates", para a coletânea $A$ 


\section{Início e fim da tradição}

O início de nossa tradição de filosofia política é localizado por Arendt de modo bastante preciso: ele se dá na reação de Platão contra a democracia ateniense e, ato contínuo, contra Homero. O século de Péricles aparece na análise arendtiana como experiência fundamental da concepção ocidental de política. A força desta experiência inaugural se conserva através dos séculos por meio do vocabulário político que chegou até nós carregando certas determinações e valores. Apesar de fundamental e originária, a experiência da polis é composta por um elemento mais antigo, a saber, certo ideal de herói representado por Aquiles na obra de Homero. A recusa de uma vida longa, feliz e anônima retira Aquiles do comum dos humanos e o coloca entre os corajosos, dispostos a grandes sacrifícios em busca da glória, única forma humana de imortalidade. Homem de grandes atos e de grandes palavras (doer of great deeds and speaker of great words), Aquiles alcança a glória porque sua ação é excelente e porque, graças ao poeta, ela é vista por muitos ao longo do tempo. Muito desta figura permanece, segundo Arendt, nos homens da polis, que, recusando o conforto anônimo daqueles que apenas assistem aos acontecimentos e às discussões da cidade, dispõem-se a ir ao centro da ágora, local em que se dá a disputa constituída de ações e palavras. Aos excelentes, está reservada imortalidade proporcional à excelência da ação e garantida por poetas ou historiadores.

Embora ainda imerso neste ambiente agonístico e luminoso, Sócrates agiu de modo diverso e um tanto desajustado, pois sua saída do anonimato não se deve a grandes atos ou palavras, mas a certa forma de encarnar publicamente o pensamento. Esta inadequação conduziu Sócrates à condenação pela cidade, evento determinante para o nascimento da tradição na medida em que levou Platão a perder as esperanças na vida da polis e a formular esta inadequação socrática em termos de uma tensão fundamental entre filosofia e política.

Deve-se notar que o desespero da vida política se faz sentir em Platão, não em Sócrates. A despeito de todas as dificuldades de estabelecer uma separação entre os dois, ${ }^{89}$

promessa da política. No Brasil, o texto foi publicado também na coletânea $A$ dignidade da política (Rio de Janeiro: Relume Dumará, 2002).

${ }^{89}$ Há uma referência rápida a esta questão em The Life of the Mind - Thinking, p. 168-9. Arendt afirma expressamente que "existe uma linha divisória nítida entre o que é autenticamente socrático e a filosofia ensinada por Platão." Em nota, ela lamenta o quão pouco as discussões eruditas contribuem para a compreensão do homem Sócrates, com exceção do "inspirado perfil" oferecido por Gregory Vlastos em "The Paradox of Socrates" (in Socrates, Plato, and their tradition, Vol II. Princeton University Press: Princeton, New 
Arendt indica um elemento no método que permite distingui-los. Como filósofo da cidade, Sócrates pensa sempre em companhia. A presença do outro não é apenas um elemento dramático dos diálogos, mas suporte constituinte da atividade mesma do pensamento socrático. A partir de um tema comum a ambos, Sócrates engaja seu concidadão em uma espécie de busca pela verdade que, ainda que frequentemente termine no vazio, retira de seu interlocutor a tranquilidade da certeza irrefletida. O simples engajamento franco nesta atividade atualiza o exercício do bem, contido no amor pelo saber e pela verdade. Este método, entretanto, encontra sérias limitações na polis; Arendt analisa uma passagem do Górgias para exemplificar a mais fundamental delas. Em dado momento, o último interlocutor de Sócrates, Cálicles, se recusa a responder às questões interrompendo assim o diálogo. Diante do silêncio, Sócrates se vê forçado a mudar seu procedimento e a "proferir um verdadeiro discurso", ou seja, a falar sozinho para alguém que apenas ouve. Além de forçar uma mudança da parte de Sócrates, a recusa ao diálogo expõe o desinteresse pelo conhecimento e implica igualmente a recusa à virtude, ao bem. Diante da facilidade com que Cálicles torna Sócrates impotente, Platão perde as esperanças de que o diálogo com concidadãos seja um bom meio para a melhoria da cidade e se afasta da postura do mestre, embora permaneça usando seu nome em seus textos posteriores. Arendt conclui que esta perturbadora impotência de Sócrates nos conduz à admissão de que nem Sócrates nem Platão sabiam como resolver filosoficamente a questão, o que justifica o recurso a um mito "certamente não socrático" - para "resolver tudo" no fim do diálogo; o mito oferece uma solução política, mas não filosófica para o problema. Diante da constatação de que o ser humano é capaz de se recusar a fazer o bem, Platão teria ouvido a prudência, virtude política por excelência, e decidido não deixar aberturas ao julgamento dos interlocutores, abandonando assim a radicalidade do método do diálogo.

Esta mudança metodológica marca a separação entre Sócrates e Platão no interior da obra platônica e marca também os diferentes procedimentos entre filosofia e política. Esta separação tende a se ampliar e, de acordo com Arendt, a parábola da caverna oferece a mais decisiva formulação da tensão entre filosofia e política. Segundo a autora, a

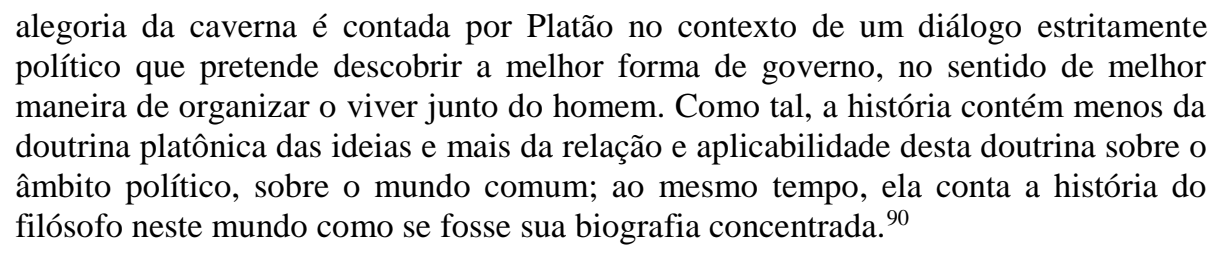

Jersey, pp. 3-18)

${ }^{90}$ Arendt, Karl Marx and the Tradition of Western Political Thought," Second draft - Part I - 
Arendt organiza sua análise da parábola nas três reviravoltas (periagoge holes tes psyches) que resultam na formação do filósofo a partir do ser humano. A primeira reviravolta se dá no interior da caverna, quando um homem se liberta dos grilhões que o forçam a permanecer ao lado de outros seres humanos e ver apenas as sombras no fundo da caverna. Longe dos demais e diante do fogo, causa das sombras, o futuro filósofo apura seu olhar e se adapta à nova situação, que o leva a se perguntar sobre a origem do fogo e a causa das coisas. Dando uma segunda reviravolta, ele encontra o caminho que o conduz para fora da caverna, sob o céu aberto, onde não há humanos nem coisas. A iluminação direta do sol - o bem, a ideia de todas as ideias - exige outro aperfeiçoamento da visão e, assim que o faz, o solitário filósofo se vê diante das essências eternas e goza de grande espanto em uma muda contemplação.

A condição de mortal exige, entretanto, que o filósofo volte a seu lar terreno, o interior da caverna. Dando uma terceira reviravolta, o filósofo volta à companhia dos demais seres humanos e logo percebe que no interior da caverna todos levam suas vidas em meio às sombras. A orientação na vida conduzida em meio às sombras exige dos humanos certa visão a elas adaptada e todos parecem tê-la, o que faz dela um sentido comum (common sense), agora tragicamente inacessível ao filósofo, pois ele está profundamente marcado pela visão luminosa das essências e pelo amor que a experiência fez nele nascer. Dentro da caverna, o filósofo aparece como um desorientado causando distúrbios às desembaraçadas pessoas que de lá nunca saíram, o que resulta em relações irremediavelmente truncadas, que só pioram à medida que o filósofo, obedecendo a seu intenso amor pelas ideias, expressa aos demais sua experiência sob a luz do sol, contribuindo assim para transformar sua desorientação em ostracismo. A reação dos demais é a desconfiança contra o filósofo, que, como a história de Sócrates ilustra, corre perigo na cidade. ${ }^{91}$

Produzida sobre o amargo pano de fundo da decadência da democracia ateniense, esta formulação de Platão enterra a experiência política fundamental da polis sob o peso da filosofia, que agora a encara como opositora. Toda a riqueza da experiência fundamental que

1953 (foto 22).

91 Outro ponto em que Arendt e Heidegger se aproximam é na interpretação deste texto platônico. Como se sabe, em "A doutrina platônica da verdade", Heidegger ofereceu também uma interpretação da alegoria baseada nas reviravoltas e na consequente "adaptação" da visão, chamada por ele de paideía ou Bildung. Em ambas as interpretações, há reflexões a respeito da forma de verdade: em Heidegger, aparece a alétheia por oposição à idea; em Arendt, a opinião ganha relevo diante da verdade. 
nos legou o próprio vocabulário político é agora encarada pela filosofia como erro, loucura, arbitrariedade, variação, enfim, como sombra, como aquilo que se forma a partir da interrupção do percurso da luz. Toda a filosofia política, aí fundada, se desenvolve por meio de certa seleção, de certo arranjo teórico que define o que entra e o que sai de seu campo de reflexão. $\mathrm{O}$ critério para tal seleção é fornecido pelo filósofo, que observa o mundo sempre a partir da vita contemplativa, do que resultou o tradicional desprezo pela vita activa e suas articulações; o bios theoretikos, formado de costas ao mundo, diante a verdade iluminada no céu das ideias, elaborou os critérios e os valores a partir dos quais devem ser julgadas as atividades do bios politikos, que age sempre apoiado em seu senso de orientação, por sua vez composto pelos sentidos, sentimentos e senso comuns a todos os seres humanos que partilham certo espaço.

De acordo com Arendt, este arranjo fundamental funcionou ao longo de milênios de pensamento unificando os autores ao longo dos tempos e só encontrou um momento sério de inflexão na filosofia de Hegel, pois foi ele quem viu, pela primeira vez, o conjunto da história mundial como um desenvolvimento contínuo. Como consequência desta realização gigantesca, a massa de valores e autoridades divergentes legados pela tradição foi convertida no desenvolvimento de uma linha dialeticamente constante e consistente, ou seja, tudo aquilo que havia de transcendente e fixo nas filosofias anteriores apareceu a partir de Hegel como construções históricas, enraizadas na particularidade de seu tempo. "O fio da continuidade histórica foi o primeiro substituto da tradição"92

As consequências deste abalo se fazem visíveis nos esforços realizados por três autores que imediatamente se seguiram a Hegel: Kierkegaard, Nietzsche e Marx tiveram que lidar com as perplexidades de um mundo em rápida mutação servindo-se de uma tradição que não mais exercia a autoridade experimentada em séculos anteriores. Embora tenham se dedicado a temas distintos - religião, metafísica e política - eles se encontram no espírito de rebelião contra a tradição, expressa no procedimento comum a todos eles de realizar conscientemente inversões na hierarquia tradicional de conceitos. Kierkegaard, em seu salto da dúvida para a crença, inverteu a relação tradicional entre razão e fé; Nietzsche, em sua transvaloração de todos os valores, inverteu a hierarquia instaurada por Platão entre sensível e suprassensível; Marx, ao definir o humano como animal laborans, recusou a tradicional definição do humano como animal rationale invertendo a hierarquia tradicional entre razão e

92 Arendt, "Tradition and Modern Age", p.27 - para a importância de Hegel na tradição, conferir a parte II do ensaio: idem. pp. 25-8 
o corpo. O resultado destas inversões, na avaliação de Arendt, foi uma derrota autoinfligida (self-defeat) para cada um deles, pois Kierkegaard, ao pular da dúvida para a fé, terminou por converter o ataque da ciência contra a religião em uma luta interna à religião, de modo que a experiência religiosa sincera passou a ser possível apenas na tensão entre dúvida e crença, "resolvida" apenas na afirmação do absurdo; Nietzsche, ao inverter Platão a fim de superar o niilismo da vida moderna, descobriu que o sensorial perde sua própria razão de ser quando o suprassensorial desaparece; Marx, ao pular da filosofia para a política, conduziu as teorias da dialética para a ação fazendo desta algo mais teorético e, quando afirmou que ação e pensamento, política e filosofia são meras funções da sociedade e da história, perdeu o significado de todas elas. ${ }^{93}$

Como a rebelião marxista é aquela à qual Arendt dedica mais atenção e a que diretamente nos interessa aqui, olhemos para ela um pouco mais de perto. Ela é composta por três inversões, que, embora se vinculem à "inversão materialista da dialética hegeliana", são mais importantes que ela. Invertendo Platão, Marx estabelece que a differentia specifica do ser humano não é a razão, mas o trabalho; que a violência (ultima ratio) é superior ao discurso (logos); que a filosofia só se realiza quando trazida ao mundo. ${ }^{94}$

A primeira inversão remete à formação do materialismo histórico por Marx, sobretudo na Crítica à filosofia do direito de Hegel e A ideologia alemã (escrita com Engels). Neste momento crucial da formação de suas ideias, Marx recusa elementos fundamentais do pensamento de Hegel e seus epígonos, pois eles impedem a identificação de uma negatividade efetivamente transformadora. Esta impotência hegeliana se deve, segundo Marx, à ausência de conexão entre as ideias e a realidade em que foram produzidas.

Pode-se distinguir os homens dos animais pela consciência, pela religião ou pelo que se queira. Mas eles mesmos começam a se distinguir dos animais tão logo começam

${ }^{93}$ Cf. Arendt, "Tradition and Modern Age", pp.29-30.

${ }^{94}$ Comparando os textos do curso sobre Marx e o ensaio "Tradição e era moderna", nota-se que a terceira inversão é diferente. Nos cursos, a terceira inversão é: ninguém que domina pode ser livre. Claramente vinculada à dialética do senhor e do escravo, esta ideia, no entender de Arendt, inverte a consideração tradicional de que liberdade e igualdade são mutuamente excludentes, o que transforma Marx em herdeiro das revoluções modernas. Embora a formulação presente nos rascunhos do curso tenha a vantagem de explicitar vínculos entre as inversões de Marx e perplexidades resultantes da revolução industrial - a definição do humano a partir do trabalho aparece como uma resposta à demanda de trabalho massificado pela indústria nascente; a violência se torna superior ao discurso porque foi por meios violentos que as revoluções modernas fundaram corpos políticos pensados por filósofos e ideólogos - optamos por não inclui-la aqui, sem antes ter uma ideia clara a respeito das razões e das consequências desta alteração. Assim, a exposição das três inversões marxistas da tradição segue aqui apenas a obra publicada, mais especificamente o ensaio "Tradição e era moderna". 
a produzir seus meios de vida, passo que é condicionado por sua organização corporal. Ao produzir seus meios de vida, os homens produzem, indiretamente, sua própria vida material. ${ }^{95}$

A differentia specifica do ser humano é claramente apresentada como produção da vida, como relação (Verkehr) com a natureza circundante, como trabalho. Arendt enxerga aqui uma substituição da tradicional concepção do ser humano como a criatura de Deus que goza de estatuto especial por ser dotada de razão em benefício da concepção de que o ser humano cria a si mesmo por meio do trabalho, a atividade mais desvalorizada pela tradição. Substitui-se aqui o animal rationale pelo animal laborans.

Uma das consequências desta recusa é a consideração de que o discurso (logos) se aproxima da ideologia e encobre as verdadeiras relações entre os seres humanos, que só vêm à tona por meio da violência. Com esta segunda inversão, Marx nega que a violência seja característica marcante da tirania e afirma que as classes dominantes detêm os meios de violência em todas as formas de governo. Assim, a ultima ratio equivale à verdadeira ação, seja no exercício da dominação, seja na tentativa de resistir a esta violência. A tradicional hierarquia entre bárbaros e civilizados garantida pela mediação do logos nas relações destes também é invertida, uma vez que a superação das formas atrasadas de modo de produção se dá precisamente por meio da recusa do logos e do recurso à violência. Apenas a ação violenta promove mudanças efetivas, dignas de serem lembradas pela história.

A última inversão marxista enxergada por Arendt se dá também em estreito vínculo com a formação do materialismo histórico e está expressa na famosa última tese sobre Feuerbach: "Os filósofos apenas interpretaram o mundo de diferentes maneiras; porém, o que importa é transformá-lo." Em termos tradicionais, a passagem da interpretação para a transformação equivale à abolição da distinção entre filosofia e mundo real. Se nos servirmos dos termos usados na análise da alegoria da caverna, esta mudança significa dizer que o mundo das ideias e o mundo do senso comum (common sense) se tornarão idênticos no momento em que a filosofia cumprir seu destino. Ela deixará de ser para os poucos que solitariamente se arriscam fora da caverna, e se tornará realidade para todos os seres humanos. Ou seja, as inversões marxistas o fazem afirmar, em aberto desafio à tradição, que a filosofia não ganhará seu sentido por meio de filósofos retirados do mundo se servindo da razão, mas, ao contrário, por meio de trabalhadores imersos na violenta luta que se dá no

${ }^{95}$ Marx e Engels, A ideologia alemã, p.87 - grifo no original 
mundo. ${ }^{96}$

Esta caracterização de Kierkegaard, Nietzsche e Marx como filósofos rebeldes confere-lhes um lugar complexo no interior do pensamento arendtiano. Ao elaborar conscientemente suas inversões, estes filósofos rebeldes iluminaram certas dicotomias fundamentais com as quais a tradição operou desde seu início. Isto não quer dizer que outros filósofos jamais tenham pensado a respeito das dicotomias tradicionais, mas significa que o questionamento sério da hierarquia em que a tradição se organizou só foi possível quando eles, na esteira dos problemas deixados por Hegel, tornaram evidentes certas estruturas fundamentais. Ao mesmo tempo em que tornaram evidentes estas estruturas da tradição, os rebeldes mostraram suas fragilidades, propuseram inverte-las e terminaram por implodir a tradição sob seu próprio peso. Desta implosão, no entanto, não resulta o rompimento dos três com relação à tradição, uma vez que a inversão de hierarquias mantém o pensamento no interior da mesma estrutura que eles inverteram, ou seja, os rebeldes estão essencialmente vinculados à tradição que eles mesmos implodiram. Este ponto de vista termina por conferir aos rebeldes uma posição bastante peculiar, uma vez que o passado não desapareceu com a implosão da tradição. Visitar os tesouros dos grandes autores do passado a fim de compreender o presente permanece como procedimento de grande importância; a própria Arendt o faz com frequência tal que é por vezes acusada de ser uma nostálgica do passado. A implosão da tradição impacta, evidentemente, na relação com os autores do passado, mas não na direção de inutiliza-los e sim na de anular o peso imposto pela tradição, de retirar o fio que atravessa a filosofia ao longo dos tempos direcionando o olhar no interior de estruturas e hierarquias que agora perderam sua força de imposição criando uma situação em que há liberdade para procurar pérolas preciosas para a compreensão do presente. A influência de Walter Benjamin é aqui evidente e mereceria desenvolvimentos, ${ }^{97}$, mas, no que se refere a

96 Para uma análise mais detida das inversões de Marx, Cf. Duarte, O pensamento à sombra da ruptura, pp.77-120; Amiel, A não-filosofia de Hannah Arendt: revolução e julgamento, pp.123-41; Weisman, Hannah Arendt and Karl Marx, pp.63-142. As de Nietzsche e de Kierkegaard são sensivelmente menos exploradas no texto da Arendt e, provavelmente em função disto, não parecem ter sido estudadas detalhadamente pelos estudiosos.

${ }^{97}$ As relações entre o pensamento de Arendt e o de Benjamin, de quem foi pessoalmente próxima, sobretudo nos anos 1930, é extenso e nos levaria para longe de nosso tema. Cf. p. ex. Arendt, "The Concept of History: Ancient and Modern" in. Between Past and Future e "Walter Benjamin: 1892-1940" in. Men in Dark Times. Cf. tb. Benhabib, The Reluctant Modernism of Hannah Arendt, pp.92-5; Duarte, O pensamento à sombra da ruptura, pp.14154; "Walter Benjamin" in Heuer et alii, Arendt Handbuch: Leben, Werk, Wirkung, pp.254-4; 
nosso contexto mais específico, notemos que a implosão da tradição altera também a relação com os três rebeldes, pois foram eles quem iluminaram as estruturas fundamentais da tradição, de modo que "Kierkegaard, Marx e Nietzsche sejam para nós como pontos de referência (guidespots) para um passado que perdeu sua autoridade." $98 \mathrm{Ou}$ seja, o olhar adequado sobre estes três autores é precisamente aquele que está atento às contradições e às derrotas autoinflingidas por meio das quais vemos a tradição ruindo e nos liberando para um novo olhar.

Com esta ideia de rebelião contra a tradição, a caracterização de Marx no interior do pensamento arendtiano dá um passo à frente. Marx surgiu, lembremos, como pensador vinculado de alguma maneira ao governo de Stalin e, pouco depois, passou a ser considerado como o ápice e o fim da tradição, para ser agora caracterizado de modo mais preciso como filósofo rebelde contra a tradição e, portanto, um guia para o passado. Esta caracterização qualifica melhor a relação que Arendt estabelece com Marx, pois evidencia, em primeiro lugar, que esta relação passa necessariamente pelo problema da tradição e, em segundo, que eles estão, ao mesmo tempo, separados pela completa ruptura com a tradição e unidos pela resistência contra ela. "Todos os três [rebeldes] ousaram pensar sem serem comandados pela tradição e pela autoridade. Quer dizer que foram os primeiros a tentar o que a própria Arendt quer tentar: pensar sem muletas, pensar sem tradição, sem guia, sem laços."99

Os intérpretes parecem se dividir neste ponto entre quem leva em conta o papel da tradição nas relações entre Arendt e Marx e quem deixa a questão de lado. Como afirmamos acima, Young-Bruhel mostrou de modo inquestionável a existência de um vínculo, no percurso arendtiano, entre Marx, o totalitarismo e a tradição. No entanto, e muito em função da natureza biográfica de seu trabalho, Young-Bruhel não retira a pertinência de intérpretes que, minimizando ou mesmo desprezando este vínculo, se lançam ao confronto direto entre Arendt e Marx. Como indicamos acima, a amplitude da noção de tradição, que reúne sob um único termo virtualmente todos os filósofos a partir de Platão fazendo uma enorme tábula rasa em milênios de pensamento, tende a diluir os autores e suas diferenças em um movimento amplo no interior do qual todos os gatos são pardos, de modo que os intérpretes que desconsideram o problema da tradição cumprem o papel de resistir à leitura arendtiana de

Matos, "Storyteller e o flâneur" in: Bignotto, / Moraes, Hannah Arendt: diálogos, reflexões, memórias, pp.90-6.

${ }^{98}$ Arendt, "Tradition and Modern Age", p.28. Cf. tb. "What is Authority?" in. Between Past and Future

${ }^{99}$ Amiel, A não-filosofia de Hannah Arendt, p.123 - grifos no original 
outros autores explicitando os pontos em que esta precisa torcer ou distorcer outros filósofos. No que se refere especificamente a Marx, estes intérpretes acompanham Bikhu Parekh, que conclui aquele que é, talvez, o primeiro texto dedicado especificamente à crítica arendtiana a Marx, afirmando que nenhum "outro filósofo político articulou a natureza, o mecanismo, a complexidade, o pathos e o significado da ação tão bem quanto ela [Arendt]", o que, entretanto, não impede que ela "fracasse completamente em apreciar a magnitude das realizações de Marx e, consequentemente, enquanto algumas de suas críticas são válidas e mereçam atenção especial, sua crítica não é persuasiva no geral." ${ }^{100}$ Parekh escreveu antes das contribuições decisivas de Young-Bruhel, mas sua influência é extensa, como prova a conclusão a que chega Arno Münster, já em 2008, para quem o conceito de trabalho de Arendt, ponto de nevrálgico da crítica arendtiana a Marx, "contém também certos aspectos positivos, [mas] aparentemente se inscreve no quadro geral de um esforço teórico que visa à refutação e à desestabilização da doutrina marxista, (...) [e] está longe de ser convincente, especialmente ali onde a autora se esforça para mostrar a 'inatualidade' ou o caráter utópico das proposições de Marx". ${ }^{101}$ A desconsideração do tema da ruptura da tradição costuma ser realizada por intérpretes oriundos de fora dos estudos arendtianos e resultar em críticas como estas, que, ao mesmo tempo, revelam uma incompreensão profunda do pensamento da autora que comentam ${ }^{102} \mathrm{e}$, talvez por isto mesmo, oferecem contribuições importantes sobre os procedimentos e os limites arendtianos. Dentre os intérpretes simpáticos à autora, muito dedicados a sua obra e que não conferem centralidade ao problema da tradição, destaca-se Benhabib, que talvez considere relutante o modernismo de Arendt precisamente porque ela, Benhabib, não está disposta a acompanhar a radicalidade da ruptura.

Do outro lado, há os intérpretes que, seguindo as descobertas feitas por YoungBruhel, consideram muito significativo o peso da tradição na leitura arendtiana de Arendt. Em geral são estudiosos bastante dedicados à obra de Arendt e que costumam abordar sua obra a partir de "dentro" dos estudos arendtianos. Canovan conferiu peso significativo à

\footnotetext{
100 Parekh, "Hannah Arendt's Critique of Marx" in. HILL, Hannah Arendt: The Recovery of the Public World, pp. 99-100.

${ }^{101}$ Münster, Hannah Arendt contre Marx ?, p.222. O texto que Teresa Calvet-Magalhães dedicou ao tema do trabalho se insere nesta mesma linhagem e é particularmente rico em revelações dos procedimentos de Arendt. cf. Calvet-Magalhães, "A categoria de trabalho (labor) em Hannah Arendt".

102 Cf. p. ex. Mészáros, I - "Vicissitudes da consciência histórica do século XX" e "Não há necessidade ou sentido" in. Estrutura social e formas de consciência: a determinação social do método. São Paulo: Boitempo, 2009, pp. 83-96; Valle, M. R. - A violência revolucionária em Hannah Arendt e Herbert Marcuse: raízes e polarizações. São Paulo: Unesp, 2005.
} 
ruptura com a tradição na leitura arendtiana de Marx e nisto foi seguida por Duarte, Amiel (de modo distinto), ${ }^{103}$ Correia e tantos outros, formando uma linhagem de intérpretes em que nos incluímos ${ }^{104}$ e que concede a Arendt o benefício de aceitar, em maior ou menor grau e para fins analíticos, as deformações que ela impõe a Marx ao considera-lo um filósofo em rebelião contra a tradição, procedimento que não impede, no entanto, de incluir as contribuições trazidas por quem opta pela outra rota. ${ }^{105}$

Vejamos agora como Arendt realiza esta desmontagem da tradição servindo-se de Marx como guia para o passado e chegando à crítica do procedimento de definição do ser humano por meio de sua differentia specifica. O movimento é claramente inspirado em Heidegger e sua explicitação exige que o vejamos surgir em Ser e tempo.

\section{Differentia specifica}

Logo no $§ 1$ de Ser e tempo, dedicado à necessidade da pergunta pelo sentido do ser, Heidegger enumera três preconceitos que todos os filósofos, ecoando o arranjo estabelecido por Platão e Aristóteles, mantém com relação ao conceito de ser: o ser é o conceito mais universal, portanto é evidente e dispensa explicação; consequentemente o ser é um conceito indefinível; por fim, o ser é um conceito que pode ser entendido por si mesmo, de modo que é inútil e desnecessário interrogar-se sobre ele. Um dos resultados destes preconceitos fundadores foi a restrição do pensamento ao campo ôntico, onde se dá a reflexão a respeito do ente, mas não do ser. Circunscrita ao âmbito ôntico e sem acesso ao ontológico, a filosofia desenvolveu uma linguagem adequada à apreensão do ente, mas incapaz de abordar de modo adequado o ser, que permaneceu esquecido desde então. Na "Carta sobre o humanismo", Heidegger indica estes arranjos sob o nome de "interpretação técnica do pensar", sobreposta ao ser por Platão e Aristóteles e responsável pelo surgimento da metafísica, que se tornou o elemento norteador e deformador de todo o pensar efetuado pelos grandes autores desde então. Desta constatação do esquecimento do ser, soterrado pela metafísica sob o ente, surge a incontornável tarefa de destruir a metafísica e libertar o pensar a respeito do ser. Heidegger não nega que outros antes dele tenham se lançado a este esforço - Nietzsche sobretudo -, mas

\footnotetext{
${ }^{103}$ Amiel parece por vezes mais interessada em conjugar Arendt e Marx do que em afastalos. Ela não apenas nota, mas parece enfatizar a proximidade entre Arendt e Marx a partir da oposição à tradição que une ambos.

${ }^{104}$ Cf. Apresentação

105 Cf. Canovan, Hannah Arendt: A Reinterpretation of Her Political Thought, pp.63-71; Duarte, O pensamento à sombra da ruptura, pp.77-120; Amiel, A não-filosofia de Hannah
} 
se considera fora desta linhagem formada por grandes filósofos porque estes não teriam sido suficientemente radicais na empreitada, uma vez que não colocaram a mais essencial das questões: a do sentido do ser.

Dentre estes três preconceitos, interessa-nos aqui mais diretamente o segundo — de acordo com o qual o ser é indefinível — porque é nele que está centrada a crítica à differentia specifica. Embora ele seja estreitamente vinculado aos outros dois e seu isolamento possa resultar em alguma dificuldade na análise, as necessidades desta exposição exigem esta torção. Logo nas primeiras páginas do tratado em que lança seu grande projeto filosófico, Heidegger afirma que quem pretender expressar uma definição qualquer do conceito de ser vê-se logo diante de um embaraço, pois percebe de saída que precisa recorrer ao verbo "ser" em sua própria definição: "o ser é...". Citando Pascal, ele considera uma absurdité empregar a palavra definida em sua própria definição e conclui que esta dificuldade decorre da universalidade absoluta do ser e da incompatibilidade desta com o próprio procedimento de definir, uma vez que este consiste em atribuir diferenças e separar em função destas diferenças. Recorrendo a Aquino, Heidegger relembra que uma "definição se faz pelo gênero próximo e pela diferença específica", ou seja, que a possibilidade de encontrar a diferença que singulariza determinado ente se deve à comparação entre entes que partilham muitas características.

Uma das pedras de toque do projeto heideggeriano está na afirmação de que esta maneira de proceder é inteiramente inadequada quando se lança à definição de ser. Dado o caráter absolutamente universal do conceito de ser, não é possível que ele seja definido adequadamente através da procura por sua differentia specifica, ou seja, pelo esforço de encontrar o que lhe é essencial através do estabelecimento da diferença que ele mantém com conceitos superiores ou inferiores. Como o ser é o mais universal dos conceitos, não existem conceitos "acima" dele que possam servir de apoio para encontrar por contraste o que lhe é essencial; inversamente, o recurso a conceitos inferiores só pode revelar que o ser está em todos os conceitos e constitui algo que em todos eles é igual, não diferente. Dada a universalidade da categoria de ser, uma definição dele só poderia conduzir ao absurdo procedimento de encontra-lo por meio de uma diferença que seria ele mesmo.

A impossibilidade de alcançar o ser por meio deste procedimento não impediu, entretanto, que os filósofos se servissem dele trilhando uma via aberta por Platão e Aristóteles. O resultado, segundo Heidegger, foi um desencaminhamento responsável por

Arendt, pp.123-209. 
limitar os filósofos ao âmbito do ente e consequentemente deixar o ser longe do alcance da filosofia tradicional. Mesmo quando pretenderam se lançar a especulações ontológicas, os filósofos se mantiveram no espaço ôntico precisamente por se servirem de alguma concepção de "ser" estabelecida pelo procedimento de differentia specifica. Os filósofos tradicionalmente alcançam o ente, mas não o ser do ente. Esta deformação inicial se desdobra e se aprofunda na necessidade lógica de buscar um fundamento sólido sobre o qual erigir a arquitetura filosófica pretendida. Restrita ao âmbito ôntico, a universalidade do ser é convertida na necessidade de um ente sobre o qual se apoiam todas as reflexões e em torno do qual todas elas ganham sentido - a Ideia, em Platão; o Primeiro Motor Imóvel, em Aristóteles; Deus, nos cristãos, judeus e muçulmanos e em toda a filosofia moderna. A metafísica aparece como o modo de pensar que exige a fundamentação do pensamento sobre um "ser" sólido e universal, mas que sempre se restringiu ao âmbito ôntico e jamais pensou propriamente o âmbito ontológico. Da impossibilidade de definir adequadamente o ser, a tradição concluiu tacitamente a impossibilidade de pensa-lo; opondo-se a esta conclusão, Heidegger pretende oferecer uma alternativa, uma maneira capaz de permitir pensar também o ser.

Esta ligeira apresentação de alguns elementos do projeto heideggeriano nos permite notar que Arendt procede num movimento análogo ao de Heidegger. O alvo arendtiano, entretanto, não é o conceito de ser, mas as definições do ser humano que servem de fundamento para as filosofias políticas ao longo da tradição. Depois de sua releitura da tradição, Arendt confirma sua suspeita e constata que, do zoon logon de Aristóteles ao animal laborans de Marx, o humano é sempre definido pelo procedimento de estabelecer sua differentia specifica relativa aos demais animais. O tradicional procedimento almeja à definição de uma essência humana destinada a ocupar o lugar do fundamento no arcabouço filosófico a ser construído, em um movimento exigido pela vita contemplativa e sem levar muito a sério as articulações no interior da vita activa. Assim como os filósofos "metafísicos" ofereceram uma definição ôntica de "ser" sob pena de relegar o ser ao esquecimento, também os grandes filósofos políticos tradicionais alcançaram uma natureza humana, mas ao preço de impossibilitar o acesso àquilo que há de espontâneo e indefinível no humano. O resultado desta espécie de esquecimento do ser humano é o desenvolvimento de uma tradição de filosofia política incapaz de pensar adequadamente a singularidade de cada um, de levar em conta aquilo que Arendt, servindo-se de Agostinho, chama de grande profundum do homem. 
Como vimos acima, o procedimento de definir por meio da differentia specifica limita o pensar ao âmbito ôntico e impede o acesso ao âmbito ontológico. Esta dificuldade se vincula ao processo de definição, que equivale ao estabelecimento de um corte fundamental que limita o que está dentro e o que está fora do ente definido. As próprias palavras tornam evidente este procedimento - de-finitio; de-terminatio; de-limitatio. $\mathrm{O}$ estabelecimento de definições é o recurso de que se servem os filósofos tradicionais para encontrar as essências e, como este processo se dá por meio do $\log o s$, seu conteúdo é necessariamente apreensível pela razão, donde a possibilidade de ser tematizado e expresso pela filosofia. Além disto, o enquadramento tradicional impõe a exigência lógica de conferir a essa essência a função de fundamento, de ponto sobre o qual a arquitetura do pensamento se erige. A principal decorrência desta montagem é que tudo aquilo que está no interior desta estrutura é passível de ser racionalizado, ao contrário de tudo aquilo que está fora da delimitação que fundamenta a construção filosófica.

A reflexão arendtiana nos permite perceber que a filosofia política também é marcada por este procedimento. Ao longo da tradição, os filósofos políticos também se lançaram à busca da melhor determinação daquilo que é o humano. Analisando a definição de Aristóteles como zoon politikon e a de Marx como animal laborans, Arendt afirma:

\footnotetext{
Estas definições se baseiam na consideração de que a espécie humana pertence à vida animal $e$ dela se distingue por certas características. (...) Como início e fim, estas definições do homem como animal trabalhador e político pertencem à mesma tradição. Em vários aspectos, elas estão em conflito entre si, em outros são exatamente opostas. Elas permanecem ainda de alguma maneira na mesma linha de pensamento, respondem às mesmas questões e assim estão em estreita comunicação uma com a outra. Como início e fim, elas limitam e abarcam quase toda a parte da vida e do pensamento que costumamos chamar de social ou político e que, de modo mais geral, é o âmbito que os homens ocidentais estabeleceram como o mundo do viver junto, que se localiza (lies) entre nós e que portanto todos temos em comum. ${ }^{106}$
}

Algo que une, portanto, toda a tradição é a consideração de que o ser humano é um animal e, dentro desta espécie, se diferencia por alguma coisa. Aristóteles e Marx não são tomados aqui por serem particularmente tradicionais (ou totalitários), mas porque representam o início e o fim deste monumental conjunto de esforços para definir o humano, em que se incluem igualmente o animal rationale, o Homo homini lupus, o proprietário, definições resultantes de um esforço de encontrar aquilo que há de essencial no ser humano e, consequentemente, apto a servir de fundamento para uma filosofia política.

À primeira vista, isto parece contradizer uma afirmação arendtiana que, na verdade, é

${ }^{106}$ Arendt, "Karl Marx and the Tradition of Western Political Thought" First draft, pasta 2, 
aqui confirmada. Em A condição humana, lemos que Aristóteles, com suas duas definições, zoon politikon e zoon logon ekhon, "não pretendeu definir o homem em geral nem indicar a mais alta capacidade humana, que para ele não era o $\operatorname{logos}\left(\right.$...), mas o nous." ${ }^{107}$ A afirmação aparece em uma seção destinada à crítica da confusão entre social e político nas definições tradicionais do humano, iniciada já na tradução latina da definição aristotélica, vertida por animal rationale ou animal sociale. Para apresentar os problemas desta confusão, Arendt afirma que o objetivo de Aristóteles não era o de encontrar, por meio da contemplação, aquilo que está presente em cada um dos humanos distinguindo-os de cada um dos animais, mas aquilo que significa a realização de potencialidades especificamente humanas, impossíveis não apenas aos animais, mas também aos bárbaros e aos escravos. É por isto que Arendt continua a passagem afirmando que, com "suas duas definições mais famosas, Aristóteles apenas formulou a opinião corrente na polis sobre o homem e a forma política de vida, de acordo com a qual todos aqueles que estão fora da polis - escravos e bárbaros — eram aneu logou, ou seja, seres privados, evidentemente, não da faculdade do discurso, mas do modo de vida em que o discurso e apenas o discurso faz sentido e em que a preocupação central de todos os cidadãos era falar uns com os outros." ${ }^{108}$ Embora afastado do procedimento platônico de procurar no céu das ideias a Ideia de homem, Aristóteles opera também com o estabelecimento de um dentro e um fora, de uma de-terminatio, que, para ele, se situa sobre a linha do modo de vida ateniense que lhe servia de modelo. ${ }^{109}$

Como vimos acima, quando tratamos do fim da tradição, Hegel representou um ponto de inflexão na tradição exigindo as rebeliões de Marx, Nietzsche e Kierkegaard e é, portanto, também importante aqui. Ao mostrar o caráter histórico de definiçõos pretensamente ahistóricas, como a de Aristóteles ou a de Hobbes, Hegel tornou difícil o esforço de definir metafisicamente o humano ao introduzir um fundamento dinâmico no mundo e no homem. Em Hegel, e a partir dele, o humano é uma relação com o mundo e esta relação se altera com o passar do tempo, de modo que o acúmulo histórico participa desta "essência" humana retirando-lhe a transcendência estática. Em outras palavras, tudo aquilo que havia de transcendente e fixo nas definições do humano que fundamentavam as filosofias anteriores se tornou, a partir de Hegel, construção histórica enraizada na particularidade de seu tempo. Esta

\footnotetext{
imagens 1 e 2 - grifos no original

${ }^{107}$ Arendt, The Human Condition, p.27

108 Arendt, The Human Condition, p.27

109 Cf. A respeito desta passagem, mas com outras preocupações, Taminiaux, La Fille de la Thrace et le penseur professionnel, p.117
} 
alteração impacta diretamente a afirmação de que o pensamento de Marx opera com a ideia de uma essência humana. Prova disto é a enorme controvérsia existente dentro e fora do marxismo a respeito da presença de uma natureza humana em Marx, pois quem recusa a presença de uma essência humana no pensamento de Marx se apoia precisamente no caráter dialético de seu pensamento, ou seja, naquilo que ele deve diretamente a Hegel. Fundamentalmente, a estratégia é mostrar que o caráter dinâmico da dialética impede a formação de uma essência em sentido tradicional, mesmo nos momentos em que Marx fala expressamente de uma.

Esta dificuldade interpretativa se assenta sobre a inequívoca afirmação marxista de que o trabalho é a essência do ser humano. Por um lado, esta afirmação dá conta das exigências de um fundamento dinâmico impostas por Hegel, uma vez que o trabalho não é concebido como uma essência imutável e a-histórica, mas é, ao contrário, a atividade por meio da qual os seres humanos realizam as mudanças que constituem a urdidura da história. Ou seja, os humanos mudam conforme a particularidade, conforme o tempo e o lugar em que vive e trabalha. Esta mesma afirmação, como vimos, sintetiza aos olhos de Arendt um dos grandes desafios postos por Marx à tradição, pois com ela o filósofo rebelde inverte a tradicional hierarquia que assegurava a superioridade da razão sobre o corpo, do espírito sobre a matéria. Assim, sem negar a novidade e a radicalidade da definição oferecida por Marx, é necessário notar que ela não significa um rompimento com a tradição, uma vez que esta se expressa na superioridade da vita contemplativa sobre a vita activa, que permanece no materialismo de Marx, uma vez que é a vita contemplativa quem exige a necessidade de pensar a partir de uma definição, mesmo que dinâmica como o trabalho. O elemento totalitário aqui indicado não está na essência escolhida, mas na ideia de que é preciso encontrar uma definição, o que Marx inegavelmente faz, assim como os demais filósofos tradicionais, incluindo os jovens hegelianos contra quem se colocou na juventude: "Feuerbach dissolve a essência religiosa na essência humana. Mas a essência humana não é uma abstração intrínseca ao indivíduo isolado. Em sua realidade, ela é o conjunto das relações sociais." 110 Toda a diatribe contra os sucessores de Hegel resultou na substituição de um fundamento por outro, esforço revelador de sua rebeldia contra a tradição, mas não o suficiente para retira-lo dela, uma vez que ele não recusa a própria necessidade de uma essência humana ou de um fundamento. Prova disto está em seu recurso à determinação de uma differentia specifica do ser humano com relação ao gênero mais próximo, como

${ }^{110}$ Marx, "Sexta tese sobre Feuerbach" in: Marx e Engels, A ideologia alemã, p.538 
evidencia a própria formulação da conhecida definição presente em A ideologia alemã, que repetimos aqui com as escusas do leitor:

\begin{abstract}
Pode-se distinguir os homens dos animais pela consciência, pela religião ou pelo que se queira. Mas eles mesmos começam a se distinguir dos animais tão logo começam a produzir seus meios de vida, passo que é condicionado por sua organização corporal. Ao produzir seus meios de vida, os homens produzem, indiretamente, sua própria vida material. ${ }^{111}$
\end{abstract}

Como o procedimento tradicional é o de estabelecer esta essência por meio do discurso, tudo aquilo que escapa ao logos costuma ficar fora da filosofia. Visto que as filosofias políticas tradicionalmente precisam colocar o humano como seu fundamento, elas se mostram pouco afeitas a pensar a respeito daquilo que há no ser humano, mas escapa à apreensão precisa do logos. Arendt se volta a esta questão neste ponto a fim de abordar a "assim chamada questão antropológica", que ela julga jamais ter sido adequadamente respondida.

\begin{abstract}
O problema da natureza humana, a quaestio mihi factus sum ("a questão que me tornei para mim mesmo") de Agostinho, parece não ter resposta tanto em seu sentido psicológico quanto em seu sentido filosófico mais geral. É muito improvável que nós, que somos capazes de conhecer, determinar e definir as essências naturais de todas as coisas que nos rodeiam e que não somos, venhamos algum dia a ser capazes de fazer o mesmo conosco — isto seria como pular sobre nossa própria sombra. ${ }^{112}$
\end{abstract}

Por se apoiarem em uma definição (de-finitio) do humano para explicar ou propor o funcionamento da política, as filosofias políticas devem necessariamente deixar algo de fora de suas reflexões. Dada a impossibilidade de pular sobre a própria sombra e de conhecer o grande profundum da alma humana, a filosofia política jamais se debruçou seriamente sobre este aspecto do ser humano que não se presta à apreensão do logos. Por se apoiar em uma essência alcançada por meio de uma delimitação racionalmente estabelecida, a tradição se concentrou naquilo que é apreensível, cognoscível e partilhado por todos os seres humanos.

Um dos passos da destruição da tradição de filosofia política é, consequentemente, incluir na arquitetura do pensamento este elemento obscuro, impossível de ser apreendido pelo logos e ser usado como fundamento. Notemos que não se trata de uma substituição do determinável pelo indeterminável, mas da inclusão deste na reflexão sobre o ser humano e o consequente estudo sobre as articulações entre determinação e indeterminação. Uma vez que este gesto impossibilita o recurso a uma essência, necessariamente determinada, com claros limites a respeito do que contém e do que não contém, esta inclusão acarreta mudanças

${ }^{111}$ Marx e Engels, $A$ ideologia alemã, p.87 - grifo no original 112 Arendt, The Human Condition, 10 
profundas na maneira de pensar o humano e a política.

Se as definições de ser humano consistem em estabelecer as características presentes em todos os humanos, elas deixam escapar aquilo que singulariza cada um de nós, deixam escapar o abismo indefinível que confere um semblante único a cada um de nós. A fim de incluir o mistério do humano no pensamento político, Arendt coloca no centro de seu pensamento a pluralidade dos seres humanos. Ao levar a sério o fato de que nenhum ser humano é idêntico a nenhum outro que tenha vivido, que viva ou que viverá neste mundo, ela pretende solapar a possibilidade de definir o humano de modo total, do que decorre que a pluralidade não é tomada como fundamento do humano, mas como uma das condições que o formam, dentre as quais estão muitas outras que podem ser perfeitamente determinadas. A introdução deste elemento indeterminado na consideração do que é o ser humano impede radicalmente o procedimento de alcançar uma essência humana perene e dela se servir como fundamento. Interditada esta possibilidade, faz-se necessário deixar de lado a reflexão sobre a essência humana e se dedicar ao pensamento sobre a condição humana, noção capaz de abrigar tanto elementos perfeitamente determináveis, como a vida e a mundanidade, quanto elementos inteiramente indetermináveis, como a singularidade.

Faz-se necessário deixar claro, entretanto, que a decisão arendtiana de incluir o indeterminado no pensamento sobre o humano não impede o funcionamento da ciência e tampouco desdenha de todas as suas descobertas. Toda essência pretende conter uma totalidade e, uma vez que foi delimitada racionalmente, é natural que surja a aspiração ao conhecimento total quando esta é transformada em objeto. No caso do ser humano, para que esta operação seja realizada, faz-se necessário abrir mão da singularidade como elemento relevante para as ações a fim de conhecer causa última destas e avançar cientificamente. Este procedimento se mostrou bastante exitoso, uma vez que, ao longo da modernidade, conhecimentos como a economia, a sociologia, a psicologia e mesmo o marketing têm efetivamente mostrado em detalhes inúmeras determinações que moldam as ações concretas dos seres humanos. Deve-se notar, no entanto, que as ciências humanas se veem sempre diante de dificuldades impostas pela irrupção do imprevisível, pela singularidade, pelo indeterminado que insiste em permanecer no humano.

A resposta tradicional da ciência a este tipo de dificuldade é normalmente dobrar a aposta e se lançar à elaboração de uma ciência superior. Como vimos acima, o jovem Marx recorre ao procedimento de differentia specifica para apreender aquilo que, por um lado, distingue os humanos dos demais animais e, por outro, une todos os humanos entre si. Anos 
mais tarde, enquanto elabora $O$ capital, o velho Marx mantém o procedimento para tentar definir o objeto de sua grande obra. Servindo-se, como de hábito, da crítica e mesmo do escárnio contra alguns de seus antecessores e considerando acertadamente que então desenvolvia um conhecimento superior das relações econômicas, ele afirma: "Produção de mercadorias e circulação de mercadorias são, porém, fenômenos que pertencem aos mais diferentes modos de produção, embora com extensão e alcances diferentes. Não se sabe, portanto, ainda nada sobre a differentia specifica desses modos de produção e não se pode, assim, julgá-los, quando apenas as categorias abstratas da circulação de mercadorias que lhes são comuns são conhecidas." ${ }^{113}$ Mais à frente, no capítulo dedicado à lei geral da acumulação capitalista, Marx se opõe a quem considera que as condições de trabalho estão mais tranquilas e liberais porque nas "controvérsias sobre esta questão, deixou-se geralmente de ver o principal, a saber, a differentia specifica da produção capitalista." Ou seja, Marx não tem dúvidas de que o ser humano e o capitalismo têm essências diferentes, porém não distingue os dois a ponto de considerar que o capitalismo tem uma essência, mas o humano não; consequentemente, a maneira de abordar os dois objetos é fundamentalmente a mesma e o conhecimento produzido a respeito dos dois avança da mesma maneira, sempre refinando mais suas categorias e se tornando capaz de conhecer mais e mais determinações, rumo à totalidade do conhecimento.

Sem negar a importância destes avanços, é necessário considerar também seus perigos. Se mantivermos em mente que eles só são possíveis ao custo da exclusão da singularidade, notaremos as perturbadoras similaridades entre a direção do movimento científico e aquilo que se passou nos campos de concentração, que, repitamos, "não se destinam apenas ao extermínio de pessoas e à degradação de seres humanos, mas servem também ao horrendo experimento de eliminar, sob condições cientificamente controladas, a própria espontaneidade como expressão do comportamento humano e transformar a personalidade humana em uma mera coisa". ${ }^{114}$ Não há uma linha que conduza inexoravelmente da ciência ao totalitarismo; o que há é uma afinidade entre ambos sustentada na ideia de que os humanos têm uma essência tão apreensível quanto as outras coisas, donde a afirmação totalitária de que "tudo é possível", pois tudo é dominável por princípio.

É contra esta pretensão à totalidade subjacente à ciência e apoiada sobre a noção de uma natureza humana, que se faz necessário pensar em termos de uma condição humana, pois

\footnotetext{
${ }^{113}$ Marx, O capital, p.100 n.73

${ }^{114}$ Arendt, The Origins of Totalitarianism, p. 438 - grifos nossos.
} 
esta, ao incluir em si aquilo que há no ser humano e excede o conhecimento, realiza a interdição das aspirações de conhecimento total do humano, uma vez que "as condições da existência humana - a própria vida, a natalidade e a mortalidade, a mundanidade, a pluralidade e a Terra - nunca conseguem 'explicar' o que somos ou responder à questão 'quem somos' pela simples razão de que elas nunca nos condicionam de modo absoluto."115 Pensar em termos de condição humana não equivale a recusar os conhecimentos a respeito do humano, mas a acolher o indeterminado que há no ser humano e é impenetrável ao conhecimento porque traz continuamente algo inteiramente novo ao mundo. Para pensar este indeterminado, faz-se necessário recorrer a outra atividade espiritual, complementar ao conhecimento e, como veremos à frente, Arendt aposta na compreensão como a maneira adequada de abordar este aspecto do humano; com ela, tem-se uma alternativa à aposta "natural" por mais ciência e, além disto, torna-se possível julgar o que estamos fazendo quando fazemos ciência. ${ }^{116}$

Seguindo de modo rigoroso as decorrências da definição do ser humano como animal laborans, Marx se mostrou capaz de explicar como funciona o modo de produção capitalista, responsável pelas enormes transformações vividas por seu século. Sua explicação oferece claramente um lugar e uma ação determinados aos participantes do sistema, de modo que há até possibilidades de prever ou mesmo fabricar certas reações e comportamentos. Desta possibilidade de assim intervir na ação humana surgiu o problema da relação entre determinação e liberdade na obra de Marx, um problema que ocupou muitos marxistas e com o qual o próprio Marx lidou ambiguamente. O importante, porém, é notar que esta indistinção entre o procedimento para definir o ser humano e para definir qualquer outro objeto não é exclusividade de Marx; ela é, ao contrário, o elo entre ele e a tradição da qual ele lutou tanto para se afastar.

Considerando o debate a respeito da determinação e da liberdade no interior da obra de Marx, não parece difícil afirmar que Arendt concordaria com aqueles que veem pouco espaço para a política na filosofia de Marx. Ela certamente recusaria, entretanto, a afirmação de que este problema é especificamente marxista, uma vez que, de seu do ponto de vista, a dificuldade da relação entre as determinações econômicas e a liberdade tem origem no

\footnotetext{
${ }^{115}$ Arendt, The Human Condition, p.11

116 Merleau-Ponty e Lefort também pensam a indeterminação como fundo inescapável do humano e das obras humanas, como aquilo que, por ser um excesso, impossibilita a definitio, uma vez que é por excesso que toda ação, toda obra, todo pensamento são indeterminados. No caso de Lefort, por exemplo, a indeterminação própria da democracia
} 
próprio gesto de fundar uma filosofia política sobre uma essência humana, o que é um traço de toda a tradição. Os limites do apreensível por esta filosofia se estabelecem sobre a linha posta por essa essência, que se centra naquilo que está presente em todos os seres humanos e deixa de lado o que os distingue entre si. Sobre uma estrutura assim cindida, a incompatibilidade entre necessidade e liberdade é inevitável, uma vez que aquilo que está dentro da essência é passível de ser conhecido e dominado, ao passo que aquilo que está fora é necessariamente tomado como um problema a ser resolvido por um conhecimento mais amplo e mais preciso ou a ser simplesmente ignorado. Estamos ainda na estrutura antinômica do ser humano como situado no mundo e, se considerarmos que as relações que se dão no interior da determinação já estão estruturalmente estabelecidas, perceberemos que não há nelas lugar para a deliberação ou a negociação que resultam em novas relações. Se considerarmos, do outro lado, que o espaço da liberdade é tomado como algo a ser apreendido melhor por um conhecimento mais preciso ou algo a ser ignorado, percebemos que a política sempre esteve fora do alcance dos filósofos tradicionais.

faz com ela dê origem ao totalitarismo como operação de determinação completa. 


\section{Capítulo 3-O novo pensar}

\section{Parte l: elementos do novo pensar}

Nos capítulos anteriores, vimos que, partindo da metáfora dos campos de concentração como laboratórios e com o auxílio das discussões a respeito da questão do humano, Arendt chegou à constatação de que a definição de ser humano alcançada a partir de sua differentia specifica com relação aos demais animais é um traço que une toda a tradição e facilita a formação de um pensamento que não é suficientemente consciente da ameaça totalitária. Apesar de seu alcance e de suas novidades, tanto o movimento da antropologia filosófica, quanto a resposta da fenomenologia e seus desdobramentos no existencialismo são insuficientemente radicais para a tarefa de combater o totalitarismo, uma vez que não extirpam a differentia specifica como procedimento fundante do pensamento. Consequentemente, a tarefa se desdobra na formulação de uma nova maneira de pensar o humano e a política, uma maneira que seja livre deste arranjo fundamental que marca a tradição, uma maneira não totalitária.

Arendt se lança à elaboração deste novo pensar no momento mesmo em que sua suspeita, oriunda dos temas e das discussões da antropologia filosófica, da revolução fenomenológica e do existencialismo, foi "amplamente confirmada" pela releitura de clássicos da tradição a partir de "nossos medos mais recentes". Depois de se ocupar do totalitarismo como evento histórico e de suas origens (Origens do totalitarismo, 1951), Arendt amplia a questão mirando em Marx (primeiro projeto de pesquisa, 1952), percebe que o problema é mais amplo e envolve toda a tradição (segundo projeto de pesquisa, 1953) e, imediatamente, começa a refletir sobre este novo pensar a respeito do ser humano e da política. O passo seguinte consistiu em procurar por elementos capazes de sustentar este novo pensar desprovido de elementos totalitários. As marcas desta preocupação são visíveis em dois textos escritos neste período, "Preocupação com a política no pensamento filosófico europeu contemporâneo" (1954) e "Compreensão e política" (1953). Vejamos de perto e por este ponto de vista o que Arendt nos diz nestes dois textos. 


\section{Elementos no panorama contemporâneo}

Ao final de "Preocupação com a política no pensamento filosófico europeu contemporâneo", ${ }^{1}$ Arendt apresenta uma espécie de programa da nova ciência política (political science) a ser elaborada depois da catástrofe e da ruptura com a tradição. Essas diretrizes são apresentadas em vínculo com o problema deixado pelo totalitarismo, mas sobretudo em estreita conexão com os filósofos de seu tempo, que lhe oferecem ferramentas para pensar e cujos limites ela pretende superar. Embora em 1954 Arendt já estivesse há mais de uma década nos EUA, ela escolhe deliberadamente o pensamento europeu como ponto de partida para a execução da tarefa que se atribuiu; mais do que isto, o mesmos temas e autores que dão corpo aos textos sobre a filosofia da Existenz e o existencialismo francês reaparecem aqui oferecendo elementos para sua reflexão. ${ }^{2}$

O texto se inicia com a reafirmação da tese arendtiana da tensão entre a filosofia e a política surgida no início da tradição. "Nós, cientistas políticos (We political scientists), tendemos a negligenciar o fato de que a maioria das filosofias políticas tem sua origem em uma atitude negativa, por vezes até hostil, do filósofo com relação à polis e a todo o âmbito das relações humanas." ${ }^{3}$ Esta situação se deve a "interesses profissionais" em estabelecer as condições necessárias para o modo de vida do filósofo, o bios theoretikos. Os profissionais da vita contemplativa foram os responsáveis por elaborar ao longo dos séculos essa nossa certeza de que a quietude das formas é superior à agitação das paixões, de que a paz é o bem supremo e de que a permanência é o critério a partir do qual deve-se julgar as formas de governo; uma boa definição do que é o humano e o consequente conhecimento de sua natureza são ferramentas fundamentais para a construção desta paz, que por sua vez é condição para a filosofia. O desprezo pela agitação da vita activa, pela instabilidade das relações humanas é muito bem expressa em um pensamento de Pascal ao qual Arendt recorre aqui e em outros textos:

\footnotetext{
${ }^{1}$ Usamos aqui o texto publicado em Essays in Understanding e não as várias versões e rascunhos deste texto existentes nos Arendt Papers. Cf. "Concern with Politics in Recent European Philosophical Thought" in: Essays in Understanding: 1930-1954 - Formation, Exile, and Totalitarianism. New York: Schocken Books, 1994, pp. 428-447.

${ }^{2}$ Richard King realizou um extenso e notável esforço em direção contrária procurando saber em que medida, "Arendt, em algum momento, se tornou uma pensadora americana, em vez de alemã" (p.3). Seu argumento não se restringe à vida de Arendt, mas também a certos traços de seu "estilo e modo de pensamento", sua preocupação com a noção de república, o papel de Tocqueville em sua obra e sua inserção nos debates americanos. Cf. King, $\mathrm{R}-$ Arendt and America. Chicago-London: The University of Chicago Press, 2015.

${ }^{3}$ Arendt, "Concern with Politics...", p.428 - Nesta abertura de texto, Arendt reivindica a ciência política, o que debatemos supra pp.29-30. Para a apresentação desta tese sobre a
} 
Em geral, só imaginamos Platão e Aristóteles com grandes túnicas de pedantes. Eram pessoas honestas e, como as outras, rindo com seus amigos; e, quando se divertiam em fazer suas Leis e sua Política, fizeram-na brincando. Era a parte menos filosófica e menos séria de sua vida. A mais filosófica consistia em viver simples e tranquilamente. Se escreveram sobre política foi para pôr em ordem um hospício; e, se fizeram menção de falar dela como de uma grande coisa, é que sabiam que os loucos a quem falavam julgavam ser reis e imperadores; entravam nos seus princípios para moderar a loucura deles na medida do possível. ${ }^{4}$

Realizando, como de costume, a análise de um período longuíssimo, Arendt afirma que este desprezo tradicional da filosofia pela política percorre os séculos e encontra um ponto de inflexão importante na filosofia da história de Hegel. Isto porque, a partir de então o filósofo se tornou capaz de conferir alguma ordem ao hospício oferecendo de modo sólido um "sentido para o âmbito político e, além disto, compreender este sentido como uma verdade absoluta que transcendeu todas as intenções desejadas e funcionou por trás das costas dos agentes políticos." ${ }^{5} \mathrm{Com}$ Hegel, surgiu a possibilidade de tratar filosoficamente da região do ser que deve sua origem exclusivamente aos humanos, pois ela passou a ser capaz de revelar uma verdade, não na caótica ação humana, mas na história formada por toda a agitação constitutiva do âmbito das relações humanas. A filosofia posterior a Hegel passou a atribuir dignidade filosófica ao que ocorre no hospício e se viu melhor preparada para lidar de modo sério com as perplexidades trazidas pelos eventos políticos. A filosofia política sempre surgiu de experiências políticas perturbadoras, a partir de Hegel, passou a contar com a enorme vantagem de se desenvolver depois de aberta a possibilidade de levar a sério as perplexidades nascidas do âmbito das relações humanas considerando-as nelas mesmas, sem o recurso a preceitos originados em experiências completamente diferentes.

Apesar desta nova dignidade, é necessário notar que a filosofia hegeliana da história ainda confere ao filósofo um local de transcendência, pois é ele quem, estando fora do âmbito das relações humanas, explica aos humanos o que se passou às suas costas. Embora a verdade e o sentido que ela porta sejam agora passíveis de permear a efetividade, elas permanecem acessíveis apenas ao espírito que abre asas ao pôr do sol. É sintomática a "tendência de filósofos modernos em falar de história quando confrontados com a tarefa de uma filosofia política", ou seja, com a tarefa de tratar do âmbito das relações humanas propriamente; talvez

origem da tradição, conferir supra pp. 85-8

${ }^{4}$ Pascal, Pensamentos, fragmento 331 (numeração Brunschvicg) em tradução de Sérgio Milliet. Miguel Abensour afirma que, para Arendt, este fragmento "tem quase valor de obsessão, pois ela volta a ele toda vez que pretende definir as relações da filosofia e da política na tradição". Ele lista quatro ocorrências da citação na obra de Arendt. (Abensour, Hannah Arendt contre la philosophie politique? p. 26). 
esta tendência seja "a última de uma longa série de tentativas de contornar a questão tentativas mencionadas por Pascal com tanto sarcasmo, admiração e sincera aprovação." ${ }^{6}$

Mas o pensamento político contemporâneo enfrenta complicações aqui. Ao desenvolver sua filosofia da história, Hegel mostrou a conexão profunda entre o pensamento e a efetividade, mas, apesar de suas pretensões contrárias, mostrou também que nem o filósofo que olha para trás nem a verdade que ele porta se situam em qualquer região transcendente ao tempo ou à história. A revelação da fragilidade da transcendência do filósofo trouxe consigo o problema do niilismo, que marca o XIX e chocou o filósofo porque este se viu fora de sua torre de marfim, ao rés do chão, de modo que os "aspectos niilistas dos movimentos políticos, especialmente evidentes nas ideologias totalitárias (que se apoiam na consideração de que tudo é possível e assim estabelecem uma base pseudo-ontológica para a afirmação niilista anterior de que tudo é permitido) eram realmente tão familiares ao filósofo que ele poderia facilmente detectar nelas as suas próprias complicações (predicaments)." 7 A preocupação com a política no pensamento filosófico europeu contemporâneo se deve muito menos à nova dignidade do âmbito das relações humanas, capaz de gerar por si perplexidades filosóficas autênticas, e muito mais à percepção de que as "complicações teóricas assumiram uma realidade tangível no mundo moderno."8 Esta percepção não conduz à questão, "inadequada e essencialmente fútil", da relação de causa e efeito entre o filósofo e a realidade — se Nietzsche é culpado pelo nazismo ou resulta do niilismo de seu tempo —, mas indica que nem o filósofo nem aquilo que ele pensa estão fora da história ou a transcendem.

Contra este pano de fundo, o conceito de historicidade (Geschichtlichkeit) passou a desempenhar papel importante na Alemanha e, em seguida, no existencialismo francês, com forte "sabor hegeliano". Heidegger o formulou em termos ontológicos, por oposição a antropológicos, e retirou completamente a transcendência que ainda sobrava em Hegel negando ao filósofo a posição de "sábio" por conhecer os padrões eternos e os valores que guiam as relações humanas. "No contexto da crise espiritual e política de nosso tempo, isto significa que o filósofo, ao lado de todos os demais, depois de perder o quadro (framework) tradicional dos assim chamados valores, não procurará nem o restabelecimento dos velhos valores, nem a descoberta de novos." ${ }^{9}$ Do ponto de vista político, este abandono da

\footnotetext{
${ }^{5}$ Arendt, "Concern with Politics...", p.430

${ }^{6}$ Arendt, "Concern with Politics...", p. 431

7 Arendt, "Concern with Politics...", p. 431

${ }^{8}$ Arendt, "Concern with Politics...", p. 431

${ }^{9}$ Arendt, "Concern with Politics...", p. 432
} 
transcendência talvez seja o resultado mais relevante e frutífero do pensamento político contemporâneo, pois abre o caminho para um reexame imanente do âmbito das relações humanas, caminho que a filosofia contemporânea procurou percorrer e que a própria Arendt pretende trilhar.

Um procedimento desta monta, no entanto, não se faz sem dificuldades ou ambiguidades. Prova disto no próprio Heidegger, que recusa a transcendência e, ainda assim, expressa a velha hostilidade do filósofo pelas relações humanas em seu desprezo pelo das Man, em cujas análises o espaço público funciona como aquilo que esconde a realidade e evita o aparecimento da verdade. E mesmo o conceito heideggeriano de historicidade, "apesar dos ganhos que proporciona", também se adequa melhor à análise de tendências — como a tecnificação do mundo ou o surgimento de um mundo em escala planetária - e muito menos à compreensão da política propriamente. Apesar de sua utilidade, "é óbvio que esta estrutura conceitual é melhor preparada para entender a história do que para fundamentar uma nova filosofia política. (...) as questões mais permanentes da ciência política que, em certo sentido, são mais especificamente filosóficas — tais como "O que é política?", "Quem é o homem enquanto ser político?", "O que é liberdade?" — parecem ter sido esquecidas completamente." ${ }^{10}$ Neste sentido, o conceito de historicidade ainda é parte da "tendência" em falar de história toda vez que surge a tarefa de formular uma filosofia política, ele "partilha com o conceito mais antigo de história o fato de, apesar de sua óbvia proximidade com o âmbito político, nunca alcançar, mas sempre perder o centro da política - o homem como ser que age." 11

As perplexidades que conduzem ao niilismo recebem duas respostas opostas no panorama desenhado por Arendt. De um lado, há autores que não levam em conta a ruptura da tradição e, desesperados com o silêncio desta e com o rebaixamento do pensamento ao movimento da história, pretendem restaurar a tradição esforçando-se para recolocar a filosofia em seu lugar de superioridade. Deste ponto de vista, a tarefa que se impõe é a de submeter novamente o temporal ao eterno, os meios aos fins; restabelecer a ordem sobre o caos filosófico que a modernidade e sua secularização nos legaram e que a tantos riscos no expõem, como provam as duas guerras mundiais. Esta não é "apenas a posição da filosofia católica moderna, mas também, e de modo mais geral, de todos aqueles - muito numerosos na Europa de hoje e escrevendo em nível muito alto - que enxergam na secularização da era

${ }^{10}$ Arendt, "Concern with Politics...", p. 433. 
moderna as raízes das perplexidades do mundo moderno." ${ }^{12}$ Ao lado de Eric Voegelin, os católicos Étienne Gilson, Jacques Maritain, Romano Guardini e Josef Pieper são citados como autores engajados na tentativa de restabelecer a ordem e a tradição.

Arendt elogia a potência que estes pensadores demonstram para despertar problemas clássicos, mas quase esquecidos no século XX. Por meio de interpretações modernas e vivazes de textos antigos, diz ela, eles são capazes de mostrar a força das questões mais essencialmente tradicionais, como aquelas "mais especificamente filosóficas" esquecidas pelo historicismo, e de contornar o que consideram o grande problema de nosso tempo, o niilismo, por meio de um restabelecimento da tradição. A admiração não impede Arendt de constatar, no entanto, que todo este esforço de reinstauração de certa ordem no caos filosófico moderno contém uma falha essencial na medida em que as perplexidades que eles procuram resolver com a ajuda da tradição são percebidas como estorvos à filosofia precisamente por não terem sido previstos pela tradição. Para tentar reatar o fio rompido, sobra-lhes apenas a investida no restabelecimento das "velhas verdades de um mundo que passou". "E ainda que tal empreitada fosse possível, a questão a respeito de qual dos vários mundos abarcados por esta tradição única deveria ser restabelecido só poderia ser respondida por meio de uma escolha arbitrária." 13

Uma condição fundamental para empreender este esforço de retorno é se imunizar inteiramente contra o hegelianismo e ignorar o caráter histórico da filosofia supondo efetivamente uma transcendência; a postura dos existencialistas franceses é exatamente oposta a esta. Abordando por este ângulo o movimento analisado doze anos antes, Arendt destaca o peso de Hegel e Marx sobre os existencialistas franceses e minimiza um tanto a influência exercida por Heidegger e Jaspers — além de oferecer uma análise mais equilibrada de Heidegger. ${ }^{14} \mathrm{O}$ caráter antitradicional dos existencialistas já se enuncia na eloquente distância que mantém da filosofia universitária, mas se expressa de modo mais significativo na aceitação do hegelianismo e do caráter inteiramente histórico da filosofia, do que decorre uma recusa a qualquer possibilidade de transcendência. Desta forma de rejeição da vita contemplativa, resulta o enorme interesse pela vita activa e, em oposição exata aos tradicionalistas, os existencialistas se dirigem à "política a fim de encontrar soluções para perplexidades filosóficas que, na opinião deles, resistem a uma solução ou mesmo a uma

\footnotetext{
${ }^{11}$ Arendt, "Concern with Politics...", p. 433

${ }^{12}$ Arendt, "Concern with Politics...", p. 433-4

${ }^{13}$ Arendt, "Concern with Politics...", p. 435

${ }^{14}$ Cf. supra pp.72-3
} 
formulação adequada em termos puramente filosóficos." 15

Diferentemente dos tradicionalistas, os existencialistas não consideram que o mundo está "fora dos eixos", mas, encarando de frente o niilismo, pensam que a própria existência humana é absurda por apresentar questões insolúveis a um ser dotado de razão. Em duas frentes distintas, ainda segundo Arendt, tiram disto todas as consequências: de um lado, Malraux e Camus formulam uma rebelião sem um sistema histórico e sem uma definição precisa de meios e fins para a ação humana diante do absurdo; de outro lado, Sartre e Merleau-Ponty "adotaram um marxismo-hegeliano como uma espécie de logique da revolução"16 sobreposta um tanto artificialmente a uma filosofia que deve seu impulso original a uma perplexidade bastante alheia tanto a Hegel quanto a Marx. Todos eles se tornaram revolucionários em alguma medida e advogam a ação como a maneira adequada de lidar com o absurdo.

\begin{abstract}
Neste humanismo ativista, a política aparece como a esfera em que, por meio do esforço de muitos em concerto, pode-se construir um mundo que constantemente desafia e desmente a condição humana; por sua vez, isto permitirá à natureza humana, concebida como a de um animal rationale, se desenvolver até o ponto de construir uma realidade, de criar condições a partir de si mesma. Os homens, então, se moverão em uma realidade inteiramente humanizada, criada pelo homem, de modo que o absurdo da vida humana cessará de existir - não, evidentemente, para o indivíduo, mas para a humanidade em meio ao artifício humano. ${ }^{17}$
\end{abstract}

Assim concebida, a rebelião existencialista opera com um fim difuso sustentado na esperança de que o ser humano, embora não possa criar valores, seja capaz de criar um mundo dotado de sentido por meio da exteriorização de algo da natureza humana capaz de transformar o mundo e, consequentemente, fazer do mundo algo mais próximo daquilo que o ser humano é. Para repetir a fórmula sartriana, o existencialismo é um humanismo porque faz o elogio da ação concebida como a ampliação da natureza humana em um processo de humanização do mundo, que dota o mundo de sentido por fazê-lo coincidir cada vez mais com o próprio ser humano. Deste ponto de vista, a rebelião existencialista é também uma rebelião contra a condição humana.

De fato, o rompimento com a tradição é bastante pronunciado aqui, pois a antiga hierarquia entre a vita contemplativa e a vita activa foi invertida e não há qualquer valor transcendente determinando as ações humanas. No entanto, o ponto de vista adotado por Arendt faz saltar à vista alguns elementos tradicionais que persistem no existencialismo

\footnotetext{
${ }^{15}$ Arendt, "Concern with Politics...", p.437

${ }^{16}$ Arendt, "Concern with Politics...", p. 438

${ }^{17}$ Arendt, "Concern with Politics...", p. 439-40
} 
deixando-o aquém da tarefa de formular uma nova filosofia política. Os existencialistas, evidentemente, recusariam a tarefa de formular e elaborar uma filosofia política, dada a radicalidade de sua rejeição da filosofia, algo com que Arendt concordaria em larga medida. Do ponto de vista arendtiano, no entanto, a necessidade de pensar o humano e a política foi imposta pelo evento totalitário e a maneira existencialista de lidar com a natureza humana coloca limites a sua contribuição para o cumprimento da tarefa imposta pela época.

\footnotetext{
É interessante que a tentativa de salvar a natureza humana em detrimento da condição humana apareça em um momento de tanta familiaridade — nos regimes totalitários e, infelizmente, não apenas neles - com tentativas de transformar a natureza humana por meio de uma transformação radical de condições tradicionais. Todos os múltiplos experimentos nas ciências e na política modernas de "condicionar" o homem não tem outro objetivo além do de transformar a natureza humana em nome da sociedade. Temo que seria otimismo demais afirmar que estes esforços contrários sejam igualmente condenados ao fracasso. Com sua imprevisibilidade intrínseca (a "escuridão do coração humano" em linguagem bíblica) - que filosoficamente significa que ela não pode ser definida como qualquer outra coisa -, a natureza humana pode ser mais maleável ao "condicionamento" e à transformação (embora talvez apenas por tempo limitado) do que a condição humana propriamente, que, de todo modo, parece permanecer como a condição sob a qual a vida na Terra foi dada ao homem. ${ }^{18}$
}

(O leitor familiarizado com A condição humana nota aqui, além da reafirmação do vínculo entre a permanência de elementos tradicionais no pensamento, totalitarismo e definição do humano, o uso significativo do termo "imprevisibilidade", fundamental na argumentação de $A$ condição humana, além de uma formulação que se tornará clássica na abertura do mesmo livro: a condição sob a qual a vida na terra foi dada aos seres humanos.)

Em um último movimento de análise, Arendt se volta ao "interesse pela política na filosofia moderna alemã, onde Jaspers e Heidegger ocupam o primeiro plano há mais de trinta anos, e onde o interesse é menos direto e mais elusivo." ${ }^{19}$ A eleição destes dois autores como os mais importantes para o debate político alemão parece um tanto arbitrária ou mesmo excessivamente ligada à biografia de Hannah. Afinal, com esta afirmação, ela ignora por completo filósofos políticos da estatura de um Lukács, intimamente ligado à Alemanha, e de toda a Escola de Frankfurt (à época deste texto, já restabelecida na Alemanha); isto para não falar dos tradicionalistas aos quais ela mesma se referiu páginas acima. Esta primeira impressão se desfaz, no entanto, quando nos lembramos de que tanto o pensamento de Jaspers quanto o de Heidegger se esforçam propositivamente para desmantelar a metafísica, para destruir a tradição. Diferentemente dos hegelianos Lukács e Adorno, dos tomistas Pieper e Guardini, de Voegelin e seu esforço para restabelecer a autoridade das ideias platônicas, de

${ }^{18}$ Arendt, "Concern with Politics...", p. 440 
Strauss e sua proposta de retorno a Atenas, Jaspers e Heidegger mantém uma relação bastante distinta com o passado e é precisamente por isto que sua contribuição é particularmente grande para a tarefa de uma formulação radicalmente nova do pensamento político. É também por este motivo que, neste texto, Arendt contradiz em alguma medida o que ela mesma afirmou doze anos antes, e sustenta que a influência de Jaspers e Heidegger sobre os existencialistas, agora considerados como fortemente marcados por Hegel e Marx, tem sido exagerada.

Além disto, Jaspers e Heidegger se distinguem de todos estes porque participam do movimento fenomenológico e, assim, conferem à filosofia um papel de relevo diante dos avanços da ciência recusando-se à sua diluição nas ciências que têm no ser humano o seu objeto. Daí a afirmação de que suas contribuições ao novo pensar político estão em suas respectivas filosofias, não nos textos em que lidam diretamente com acontecimentos contemporâneos ou expressam suas convicções políticas, pois estes trazem ainda inúmeros elementos tradicionais. A relação entre Heidegger e o nazismo torna incômodo este desvio, pois faz com que ele pareça um esforço deliberado para tirar a atenção de suas posições políticas durante os tempos sombrios. Este incômodo diminui consideravelmente quando consideramos que este desvio dos textos diretamente políticos também se aplica a Jaspers, que intervinha com frequência no debate público e gozava então do status de ser "a consciência alemã" precisamente por ter sido proscrito pelo nazismo. ${ }^{20}$ Esta dissociação entre os "textos filosóficos" e "textos políticos" não se assenta tanto nas opiniões que ambos mantiveram a respeito da Alemanha - em geral, mas nem sempre, distintas entre $\mathrm{si}^{21}$ — mas

\footnotetext{
${ }^{19}$ Arendt, "Concern with politics...", p. 440

${ }^{20}$ Cf. Safranski, Heidegger, um mestre da Alemanha entre o bem e o mal, p.433 ss.

${ }^{21}$ Embora Karl Jaspers não tenha sido preso ou enviado para campos de concentração, ele sofreu bastante nas mãos dos nazistas porque opôs resistência a eles e, sobretudo, porque era casado com uma judia - Gertrude, née Mayer. Deve-se notar, no entanto, que sua resistência ao nazismo não foi de primeira hora. Antes de ascender ao poder, o partido nazista propunha uma reforma do ensino superior contrária a certos ideias liberais então em voga, o que conquistou a simpatia de inúmeros intelectuais insatisfeitos com canalização da universidade para fins profissionalizantes, não de formação ou ciência. A nomeação de Heidegger para a reitoria da Universidade de Freiburg pelos nazistas pareceu a muitos como a confirmação de que uma nova universidade se reformaria no sentido da universitas localizando a filosofia em papel de destaque no sistema. Embora tenha percebido "algo ameaçador" na figura de seu amigo Heidegger, Jaspers elogiou o discurso de reitorado e, empolgado com as possibilidades abertas pelo novo governo, elaborou ele mesmo algumas teses para a reforma universitária nazista e se movimentou para que fossem recebidas pelo governo. Seu insucesso em ser ouvido, como ele mesmo o afirma, se deve ao fato de não ser membro do partido e casado com uma judia e foi apenas aí que passou a se distanciar do projeto universitário nazista, até ser compulsoriamente desligado da universidade em 1937. Heidegger e vários outros intelectuais que alimentava a fantasia de refundar a
} 
no fato de que ambos ainda partilham da tradicional hostilidade do filósofo contra a política. Apesar do comprometimento com a ruptura, quando olham diretamente para a polis, Jaspers e Heidegger não se distanciam dos hegelianos, marxistas, tomistas ou platônicos e procedem munidos de "postulados especificamente filosóficos sobre política", ${ }^{22}$ olham para a política ainda com o desprezo que acometia Platão e Aristóteles diante do hospício. Vimos acima que, no entender de Arendt, esta hostilidade tradicional aparece na análise heideggeriana do das Man; em Jaspers, ela aparece na abordagem do homem no singular - o que não é o mesmo da abordagem da singularidade de cada ser humano, como veremos.

A relevância de Jaspers neste contexto está na transformação por ele realizada do conceito de verdade, que agora habita a comunicação, ou melhor, é a comunicação. Destacando a segunda das conhecidas "questões kantianas", presentes em nosso percurso desde o capítulo anterior - $\mathrm{O}$ que posso conhecer? O que devo fazer? O que posso esperar? - Arendt apresenta Jaspers como o único "discípulo convicto" de Kant, por conta da articulação que ambos fazem entre a comunicação e a noção de humanidade. Em Kant, a moralidade é essencialmente política porque é concebida como uma capacidade de legislar que, diferentemente do que pensava a tradição, não se restringe apenas aos homens de governo, mas a toda a humanidade. Ao afirmar que a ação individual deve estar em acordo com um princípio que possa ser convertido em lei universal, estabelece-se uma conexão fundamental entre o indivíduo e a humanidade inteira, de modo que esta se converte no princípio orientador das ações individuais.

Com os desdobramentos dos séculos XIX e XX, Jaspers considera que a humanidade deixou de ser apenas um princípio orientador das ações individuais e passou a ser uma realidade política presente. Diante desta nova situação global, em que o mundo está menor e o número de pessoas está maior, a comunicação entre os seres humanos ganhou importância existencial particular. $O$ papel do filósofo nesta nova situação é levar a sério a compreensibilidade de todas as verdades trazidas pelos humanos, o que pressupõe a boa vontade de ouvir e revelar verdades, de modo que "a comunicação constitui o centro 'existencial' e se torna efetivamente idêntica à verdade. (...) A comunicação não é 'expressão'

academia platônica na Alemanha do século XX levaram sua boa vontade muito mais longe, pois sua empolgação só perdeu vigor quando perceberam que a universidade se encaminhava para os conhecimentos industriais exigidos pela economia de guerra então em funcionamento, quando notaram que Hitler não tinha reservado a eles o local mais alto na hierarquia do saber. (Safranski e Grunenberg apresentam bem este ponto e discordam quanto à relação entre Heidegger e a universitas. Cf. Safranski, Heidegger, pp.297-327; Grunenberg, Hannah Arendt et Martin Heidegger, pp.196-203.) 
de pensamentos ou sentimentos, de maneira que seria apenas secundária a eles; a própria verdade é em si mesma comunicativa e desaparece fora da comunicação. O pensar, na medida em que pretende atingir a verdade, deve necessariamente terminar em comunicação, tornando-se prático, embora não pragmático." ${ }^{23}$ Esta concepção de filosofia como mediação entre verdades traz consigo a enorme vantagem de que a razão se torna um vínculo universal entre os seres humanos sem estar acima deles, mas permanecendo entre eles, localizando-se ali onde está a vida prática.

Apesar de oferecer enorme ganho, no entanto, esta noção de comunicação apresenta uma limitação decisiva para o novo pensar político porque Jaspers a elabora a partir da experiência do diálogo entre Eu e Você e este, por sua vez, remete à experiência original do pensar, não do agir. Arendt reafirma aqui a ideia, presente já em Origens do totalitarismo, mas desenvolvida apenas em $A$ vida do espírito, seu último trabalho, segundo a qual o pensar é um diálogo de alguém consigo mesmo. Esta formulação, retirada do Teeteto de Platão, traz consigo pouquíssimas experiências especificamente políticas e constitui uma das atividades fundamentais do filósofo. É fato que, concebido como diálogo, o pensar adquire um elemento de pluralidade, uma vez que um diálogo só pode existir quando há dois. No entanto, este "outro" com quem dialogo quando penso é também eu mesmo, de modo que esta pluralidade aqui existente é mínima e inapropriada para a elaboração teórica a respeito da atividade que ganha sentido na e pela condição humana da pluralidade, que não lida com o outro, mas com outros.

A maior parte das atividades cotidianas de nossa vida normal contém mais experiências especificamente políticas do que o pensar. Ao ir à padaria, assistir ou dar uma aula, passear com os filhos, se encontrar com familiares ou colegas de trabalho, atualizamos em algum grau a condição humana da pluralidade, seja porque outras pessoas aparecem para nós em sua insubstituível presença, seja porque aparecemos a elas em nossa irrepetível singularidade. É por isto que "[T]alvez — mas eu devo apenas sugerir isto - o conceito heideggeriano de 'mundo', que em vários aspectos ocupa o centro de sua filosofia, constitua uma saída para esta dificuldade [de conceber a política a partir do pensar e da filosofia]. De todo modo, porque Heidegger define a existência humana como ser-no-mundo, ele insiste em conferir significado filosófico a estruturas da vida cotidiana que são inteiramente incompreensíveis se o homem não for compreendido, em primeiro lugar, como ser com

${ }^{22}$ Arendt, "Concern with Politics...", p. 440

${ }^{23}$ Arendt, "Concern with Politics...", p. 441 
outros." 24 A filosofia de Heidegger repete a hostilidade da filosofia contra a política em sua análise negativa da pluralidade enquanto das Man, enquanto distanciamento da autenticidade do Dasein. No entanto, talvez até sem se dar conta, ofereceu um caminho para a reflexão filosófica a respeito da pluralidade ao conceber a existência humana como lançada no mundo, portanto em relação com outros. Mostrando uma completa reviravolta na interpretação de Heidegger apresentada doze anos antes, quando sua filosofia foi apresentada como o ápice do solipsismo, Arendt afirma que esta imbricação entre a análise do cotidiano, o mundo e a pluralidade podem contribuir para a realização da tarefa de formular um novo pensar sobre a política.

Terminadas as análises, Arendt parte para um último movimento do texto, em que oferece uma espécie de balanço do pensamento contemporâneo a fím de aquilatar a contribuição destes pensadores para a elaboração do novo pensar político. Evidenciando um dos critérios para a escolha destes autores, ela afirma que todos eles têm em comum a convicção de que a filosofia não perdeu sua relevância diante de "ciências ou pseudociências, como o materialismo marxista, a psicanálise, a lógica analítica, a semântica ou o que quer que seja". ${ }^{25}$ Em outras palavras, nenhum destes autores cedeu à tendência de enterrar a filosofia sob as ciências ou sequer dilui-la nas descobertas científicas, embora considerem que o desenvolvimento e a ampliação das ciências tenham colocado novos desafios à filosofia. Além disto, é importante notar que todos os autores aqui analisados recusam a crença hegeliana de que os acontecimentos históricos, não importa o mal que venham eventualmente a causar, sempre ofereceriam um saldo positivo ao olhar posterior do filósofo, de modo que certo avanço pudesse ser sempre verificado. Esta possibilidade foi interditada com o surgimento do "mal radical", realizado nos campos de extermínio totalitários, a partir do qual não é possível deduzir qualquer sentido positivo. "Nada parece mais questionável hoje do que a ideia de que o curso da história caminha em si e por si na direção da realização de mais e mais liberdade. Se pensarmos em termos de correntes e tendências, o oposto parece muito mais plausível." ${ }^{26}$ Neste sentido, a preocupação do atual pensamento filosófico europeu pela política é composta também pelo horror dos acontecimentos contemporâneos, aos quais devem ser somadas as ainda mais sombrias perspectivas abertas pela Guerra Fria.

Além destas duas convicções, cada um dos citados ao longo da análise arendtiana traz

\footnotetext{
${ }^{24}$ Arendt, "Concern with Politics...", p. 443

${ }^{25}$ Arendt, "Concern with Politics....", p. 444

${ }^{26}$ Arendt, "Concern with Politics...", p. 444
} 
consigo um pré-requisito necessário à formulação do novo pensar político.

Dentre eles está a reformulação jaspersiana da verdade, a análise heideggeriana da vida cotidiana comum, bem como a insistência dos existencialistas franceses na ação contra as velhas suspeitas filosóficas. (...) Para uma nova filosofia política, será crucial uma investigação a respeito do significado político do pensar para um ser que nunca existe no singular e cuja pluralidade essencial está longe de ser explorada quando uma relação Eu-Você é adicionada à compreensão tradicional do entendimento humano. Tais reexames precisam permanecer em contato com as questões clássicas do pensamento político, tais como apresentadas a nós em muitas variações pela filosofia católica atual. ${ }^{27}$

A esta lista muito precisa dos elementos do pensamento contemporâneo que devem participar do novo pensar político, é necessário somar também os limites de cada pensador listados com precisão ao longo das análises, a saber: o diálogo entre Eu-Você como o modelo da comunicação e da verdade em Jaspers; a concepção heideggeriana do espaço público como das Man, como o impessoal que encobre a autenticidade do Dasein; a rebelião existencialista contra a condição humana em favor da natureza humana; o esforço de retorno realizado pelos tradicionalistas.

Munidos destas duas listas elaboradas com o cuidado de quem se lança à caça de pérolas, podemos avaliar com precisão o lugar em que Arendt se coloca no panorama do pensamento político contemporâneo. De modo consciente, ela está fora da tradição, portanto próxima a quem se engaja na tarefa de elaborar um novo pensar; suas questões e referências estão no pensamento europeu, que a formou, não no americano, que a recebeu; no interior do pensamento europeu, ela se alinha a quem aposta na filosofia e, embora esteja consciente dos desafios postos à filosofia, não cedeu aos assaltos da ciência sobre esta.

Mas falta algo ainda. Embora estes elementos positivos e negativos portem grande força, falta à preocupação com a política no pensamento filosófico europeu contemporâneo um elemento essencial a toda e qualquer filosofia. Nos últimos parágrafos do texto, Arendt nos lembra que, segundo Platão e Aristóteles, a filosofia ganha seu impulso inicial no thaumadzein, no espanto diante daquilo que é como é: ora, nenhum dos elementos citados como componentes do novo pensar político pode cumprir esta função. Não tanto porque lhes falte alguma força ou "profundidade" especial, mas porque o panorama filosófico contemporâneo ainda está atado tanto a Platão quanto a Aristóteles na recusa de conferir à filosofia política um espanto que lhe seja próprio. Se voltarmos uma vez mais ao comentário de Pascal, nos lembraremos que a filosofia política é tradicionalmente tida como "a parte

${ }^{27}$ Arendt, "Concern with Politics...", p. 445 
menos filosófica" da filosofia, aquela que se faz brincando a fim de apenas moderar a loucura reinante nas relações humanas. O pensamento contemporâneo, embora tenha contribuído muito para o rompimento com a tradição e traga em si o horror experimentado no século XX, não levou as relações humanas a sério o suficiente para transforma-las em seu espanto original, e o "horror mudo diante daquilo que o homem é capaz de fazer e do que o mundo pode se tornar está, de muitas maneiras, relacionado ao espanto mudo de gratidão a partir do qual surgem as questões filosóficas." 28

Portanto, a diferença mais fundamental que Arendt enxerga entre seu próprio pensamento e os dos demais filósofos contemporâneos está precisamente nesta decisão de atribuir o máximo de seriedade filosófica ao horror. Não se deve concluir disto, evidentemente, que Arendt esteja imputando à comunidade filosófica alguma falta de sensibilidade diante do sofrimento produzido pelas fábricas da morte. Trata-se, uma vez mais, de uma discussão com a tradição da filosofia política em seus desdobramentos contemporâneos, trata-se de perceber a ocasião para um passo à frente no desmantelamento dos arranjos originais que deram forma à tradição.

\footnotetext{
Como todos os demais ramos da filosofia, uma autêntica filosofia política só pode surgir de um gesto original de thaumadzein, cujo impulso de curiosidade (wondering) e, portanto, de questionamento deve agora (isto é, ao contrário do ensinamento dos antigos) se dirigir diretamente ao âmbito das relações e das ações humanas. Sem dúvida, os filósofos, com seu interesse consagrado em não ser perturbados e com sua experiência profissional com a solidão, não estão especialmente bem equipados para realizar este gesto. Mas quem mais está apto a fazê-lo se eles nos faltarem? ${ }^{29}$
}

Este término em forma de pergunta, seja ele ideia do editor do texto ou da autora, é significativo porque evidencia que Arendt assumiu para si a tarefa de elaborar esta autêntica filosofia política ${ }^{30}$ exigida pelo evento totalitário. Esta filosofia será composta por estes elementos retirados do pensamento contemporâneo, pela transformação das relações humanas em espanto original, pela recusa da hostilidade do filósofo em olhar para a política como quem olha para o hospício. O objetivo desta nova filosofia política não será o conhecimento, mas a compreensão, noção à qual Arendt dedicou um ensaio nesta mesma época.

\section{Compreensão}

O caráter inédito e inominável do horror realizado nos campos de concentração e

\footnotetext{
${ }^{28}$ Arendt, "Concern with Politics...", p. 445

${ }^{29}$ Arendt, "Concern with Politics...", p. 445-6.

30 Esta expressão não aparece originalmente no trecho citado, mas no período
} 
extermínio exigiu a elaboração de novas formas de pensamento. O cumprimento desta tarefa deu ocasião a um dos grandes debates intelectuais pós 1945 na Europa, do qual faz parte a a célebre Todesfuge de Paul Celan, "a Guernica da literatura europeia do pós-guerra", ${ }^{31}$ bem como a polêmica afirmação de Adorno, segundo a qual escrever um poema depois de Auschwitz é um ato de barbárie. ${ }^{32}$ Também as preocupações com memória, mito e identidade alemã presentes na obra de Anselm Kiefer, ${ }^{33}$ e os desenvolvimentos seriais presentes em Il canto suspenso, de Luigi Nono, compositor também de Ricorda cosa ti hanno fatto in Auschwitz, ${ }^{34}$ se inserem neste movimento maior de tentar encontrar um rumo depois da catástrofe e tentar elaborar as relações entre ela e a cultura ocidental. ${ }^{35}$ Mais recentemente, Agamben afirmou que já se pode considerar esclarecido o quadro geral das circunstâncias históricas do extermínio dos judeus, ao contrário do "significado ético e político do extermínio, ou mesmo [da] simples compreensão humana do que aconteceu", ${ }^{36}$ que permanece ainda um tema difícil em que se avançou pouco.

A contribuição de Arendt para este debate passa por sua noção de compreensão, tema ao qual ela se dedica desde pelo menos o prefácio de Origens do totalitarismo, onde encontramos a consciência de uma novidade assustadora contra a qual se faz necessário lutar com o auxílio da compreensão (comprehension). Esta constatação exige o firme posicionamento na brecha entre passado e futuro, neste angustiante presente que tem no totalitarismo seu evento central. Não é por outro motivo que na epígrafe ao livro lê-se a

imediatamente anterior, de modo que a transposição não distorce o sentido.

31 Felstiner, J - Paul Celan: poeta, superviviente, judío. Madrid: Trotta, 2002, p.56. Cf. Aron, I. "Paul Celan: a expressão do indizível" in: Pandaemonium Germanicum. n.1, 1997, pp.77-85; Forster, R - "Paul Celan y la barbarie de la lengua" in: Los hermeneutas de la noche. Madrid: Trotta, 2009, pp.95-115.

${ }^{32}$ Cf. Adorno, T - "La crítica de la cultura y la sociedad" in: Prismas: la crítica de la cultura y la sociedad. Barcelona: Ariel, 1962, pp.9-29. Cf. tb. Adorno, T - "Educação após Auschwitz". in: Educação e emancipação. São Paulo: Paz e Terra, 2003, p.119-138.

${ }^{33}$ Cf. KIEFER, Anselm. "Pintar como feito histórico".in Gávea, PUC-RJ, n.8, p.112-24, 1990; Huyssen, A - "Anselm Kiefer: The Terror of History, the Temptatntion of the Myth" in: Twilight Memories: Marking Time in a Culture of Amnesia. New York: Routledge, 1995, pp.209-48; Santiago-Ramos, L - Pequena história do mal: Anselm Kiefer e Walter Benjamin. 2009. 362f. Tese (doutorado) - curso de filosofia, Universidade de São Paulo, São Paulo.

${ }^{34}$ Cf. Nielinger-Vakil, C - Luigi Nono: A Composer in Context. Cambridge University Press, 2015; Nanni, M - Auschwitz: Adorno und Nono. Freiburg: Rombach, 2004.

35 Uma extensa coletânea dedicada à arte vinculada à catástrofe, com relatos de sobreviventes, textos de ficção e também pinturas, se encontra em Langer, $\mathrm{L}-$ Art from the Ashes: A Holocaust Antology. New York-Orxford: Oxford Univertity Press, 1995. Uma ótima reunião de textos, enriquecida com excelente bibliografia de referência se encontra em Nestrovski, A / Seligmann-Silva, M - Catástrofe e representação. São Paulo: Escuta, 2000. ${ }^{36}$ Agamben, O que resta de Auschwitz, p.19 
seguinte frase de Karl Jaspers: Não estar preso ao passado nem ao futuro. O importante é estar inteiramente no presente. ${ }^{37}$ Pressionada pelas então recentes guerras mundiais e pelo medo de uma guerra nuclear, a autora afirma neste prefácio que seu livro foi escrito contra o desespero e o otimismo irresponsáveis, decorrentes das superstições do progresso e da danação (Doom). Para confrontar estas superstições, Arendt professa a fé na capacidade humana da compreensão (comprehension), aqui descrita como a capacidade de "examinar e suportar conscientemente o fardo que nosso século colocou sobre nós - sem negar sua existência, nem se submeter docilmente a seu peso. Compreender significa, em suma, enfrentar a realidade sem premeditação, com atenção e a ela resistir - qualquer que seja ela." 38

Mais à frente, imediatamente após afirmar que os campos são a instituição central do totalitarismo, a autora se volta a duas maneiras distintas e então comuns de lidar com o horror dos campos. A primeira delas se expressa nos relatos feitos por sobreviventes de campos de concentração, que, no juízo de Arendt, variam muito em qualidade e são "tão mais autênticos quanto menos se esforçam para comunicar coisas que escapam da compreensão (understanding) e da experiência humanas". ${ }^{39}$ Mostrando-se sensível a um problema que futuramente se tornaria central para as discussões ao redor da literatura de testemunho, Arendt toma como critério de avaliação dos relatos o caráter um tanto irreal e completamente incomunicável do que se passou nos campos. Certamente vincula-se a isto sua admiração pelo trabalho de David Rousset, de onde tira a epígrafe para a terceira parte de Origens do totalitarismo, sobre o qual sustenta muito de suas descrições dos campos e suas reflexões sobre as dificuldades de transmitir o horror que ali aconteceu.

O universo concentracionário fecha-se sobre si próprio. Continua agora a viver no
mundo como um astro morto carregado de cadáveres. Os homens normais não sabem
que tudo é possível. Ainda que testemunhos forcem a sua inteligência a admiti-lo, os
seus músculos não acreditam. Os concentracionários sabem. O combatente que
passou meses na zona de fogo conheceu a morte. A morte habitava entre os
concentracionários durante todas as horas de sua existência. (...) [Os
concentracionários] Caminharam durante anos no cenário fantástico de todas as
dignidades em ruínas. Foram separados dos outros por uma experiência que é
impossível transmitir. ${ }^{40}$

${ }^{37}$ Weder dem Vergangenen anheimfallen noch dem Zukünftigen. Es kommt darauf an, ganz gegenwärtig zu sein. Arendt, The Origins of Totalitarianism, pp.vii-ix

${ }^{38}$ Arendt, The Origins of Totalitarianism, pp.viii

${ }^{39}$ Arendt, The Origins of Totalitarianism, p.439

${ }^{40}$ Rousset, $O$ universo concentracionário, p.109. Arendt também se apoia bastante sobre 0 outro relato de Rousset, Les jours de notre mort, e se refere a alguns outros, mas curiosamente não inclui os de Primo Levi. Cf. Arendt, The Origins of Totalitarianism, p.439 
Esta admissão da impossibilidade de transmitir os horrores notada por Rousset na primeiríssima hora marca muitos autores, dentre os quais Arendt, que soma a esta percepção sua noção de ruptura permitindo uma conexão entre esta impossibilidade e a necessidade de formular uma nova maneira de tratar certos temas. Um relato que não parte desta admissão de incomunicabilidade pode oferecer uma série de elementos importantes para o conhecimento do que se passou nos campos, mas ajuda pouco em sua compreensão; esta mesma limitação constitui, mutatis mutandis, o pensamento político que não leva a sério a necessidade de encarar de frente o horror que ultrapassa a compreensão.

A outra maneira comum de lidar com o horror dos campos é a elaboração de racionalizações a partir dos vários elementos que permitem analogias e recurso a exemplos passados. "Há uma grande tentação de evadir-se do intrinsecamente inacreditável com explicações (explain away) baseadas em racionalizações livres (liberal rationalizations). Em cada um de nós esconde-se um liberal nos persuadindo com a voz do bom senso." ${ }^{41}$ Esta maneira de proceder se revela equivocada porque não percebe a novidade do que se passou nos campos e continua a considerar possível pensar por meio das categorias anteriores à completa ruptura realizada pelo totalitarismo; ou seja, esta postura é a de quem não encara de frente o horror e as perplexidades por ele produzidas. "Tentamos classificar como criminoso algo que, todos sentimos, esta categoria jamais pretendeu cobrir. Qual sentido tem o conceito de homicídio quando estamos confrontados com a produção em massa de cadáveres?"42 Georges Bataille é citado aqui como exemplo deste equívoco. Em um texto publicado em sua revista, Critique, dedicada especialmente ao comentário de obras recentemente publicadas e à reflexão a partir delas, ${ }^{43}$ Bataille analisa e comenta quatro livros sobre a URSS ${ }^{44}$ tomando como fio condutor a questão da industrialização soviética e os horrores a ela associados. Ao longo do texto, Bataille se mostra ciente do terror stalinista e o condena de tempos em tempos, mas não abre mão de defender a industrialização soviética afirmando seu papel para a construção do socialismo e creditando a ela tanto a vitória militar sobre Hitler quanto a

n.126.

${ }^{41}$ Arendt, The Origins of Totalitarianism, p.439-40.

${ }^{42}$ Arendt, The Origins of Totalitarianism, p.441

${ }^{43} \mathrm{O}$ subtítulo da revista é Revue génerale des publications françaises et étrangères.

${ }^{44}$ São eles, segundo o próprio artigo: 1) KRAVCHENKO, V-A - J'ai choisi la liberté: la vie publique et privée d'un haut fonctionnaire sovietique. [traduzido do inglês americano por Jean de Kerdéland]. Éd. Self, 1947, in-8o, 640p.; ALEXINSKY, G — La Russie révolutionnaire: Des émeutes de la Russie agraire à l'organisation stalinienne. Lib. Armand Colin, 1947, in-8ㅇ, 268p.; CHAMBERLIN, W-H - L'Énigme russe [traduzido por Roger Duhamel]. Montréal, Éd. De l'arbre, 1946, in-8ㅜ, 376p.; JORRÉE, G. — L'URSS: La terre et 
permanência do "otimismo radiante" que tomava a Europa algumas décadas antes e agora só se via na URSS. Operando assim em duas frentes - a condenação dos horrores da industrialização e a defesa dos benefícios trazidos por ela - ele se vê forçado a procurar um equilíbrio difícil, o que também o conduz à necessidade de compreender. "Não quero aqui justificar, mas compreender (comprendre): e, para tanto, me parece superficial se deter no horror. É fácil demais afirmar, apenas porque uma repressão foi terrível, que odiamos o terror e que a doçura teria obtido melhor êxito." 45 A noção de compreensão aqui em jogo é muito distinta da arendtiana precisamente porque Bataille se serve dela para contornar o horror, do que resulta que sua incapacidade de oferecer algo além de descrições acuradas e, com elas, pretender retirar do caminho certos inconvenientes contribuindo assim para o êxito da grande tarefa da industrialização.

Para deixar claro: o problema central para Arendt não é a possível relativização dos crimes stalinistas, por enervante que ela possa ser, mas a não percepção de que algo muito sério e muito profundo se rompeu com o surgimento do totalitarismo e de sua instituição central. Tanto nos relatos de sobreviventes quanto nestas racionalizações, ela identifica "uma tendência para a fuga da experiência; instintivamente ou racionalmente, os dois tipos de escritores estão tão conscientes do terrível abismo que separa o mundo dos vivos e o mundo dos mortos-vivos que não conseguem fornecer nada além de uma série de ocorrências relembradas que parecem ser tão incríveis para quem relata quanto para sua audiência."46 Tanto o esforço para comunicar o que ultrapassa a experiência e a compreensão humanas, quanto a consideração de que é superficial atentar para o horror escapam do principal, que é ater-se à experiência, o que, neste caso, significa encarar o abismo entre o mundo dos vivos e o dos mortos-vivos. Deixar de olhar para ele, por qualquer que seja o motivo, equivale a uma capitulação e impede a compreensão do que ocorreu efetivamente.

Em Origens do totalitarismo, Arendt coloca em prática algumas maneiras de lidar com o horror. O aspecto mais visível deste esforço está na afirmação de que só é possível descrever o abismo que precisamos encarar por meio de imagens retiradas de uma vida após a morte, donde sua comparação dos campos ao Hades, ao purgatório e ao inferno, as três formas de vida após a morte concebidas no ocidente. ${ }^{47}$ Apesar do impacto desta passagem para as discussões a respeito do problema da memória, interessam-nos aqui mais

les Hommes. Societé d'Éditions Françaises et Internationales (S.E.F.I), 1945, in-8º, 407p.

${ }^{45}$ Bataille, "Le sens de l'industrialisation soviétique", p.72

${ }^{46}$ Arendt, The Origins of Totalitarianism, p.441

${ }^{47}$ Cf. Arendt, The Origisn of Totalitarianism, p.445 
decisivamente as reflexões "epistemológicas" a respeito da compreensão, elaboradas por Arendt alguns anos depois e apresentadas em "Compreensão e política", de $1953 .{ }^{48}$

O termo "epistemológico" não é exato porque a noção de compreensão é aqui elaborada e defendida precisamente para se contrapor à noção de conhecimento. Servindo-se de seu habitual procedimento de elaborar distinções, Arendt apresenta seu argumento por meio das diferenças entre a atividade de conhecer e a atividade de compreender, do que decorre uma oposição entre o que fazem, de um lado, as ciências humanas e a história moderna e, de outro, a ciência política - campo de atuação que Arendt reivindica aqui, com as dificuldades que vimos acima. ${ }^{49} \mathrm{O}$ terreno comum que permite a comparação entre estas duas diferentes atividades é a luta contra o totalitarismo, travada de dois modos distintos: o conhecimento enfrenta o totalitarismo por meio da busca pela verdade do que aconteceu; a compreensão, por sua vez, pela elaboração do sentido daquilo que se passou.

Logo no primeiro parágrafo, lemos que compreender o totalitarismo é uma tentativa de se reconciliar com a realidade e de tentar estar em casa no mundo, mesmo depois de tudo o que se passou. Diferentemente do conhecimento, que se acumula no tempo de modo indefinido ao longo das gerações de cientistas, a compreensão se restringe ao período de uma vida: "A compreensão começa com o nascimento e termina com a morte." ${ }^{50}$ Isto quer dizer que ela não conta com uma transmissão imediata vinda do passado e tampouco resulta em algo a ser entregue ao futuro; a compreensão mantém relações com o passado e com o futuro, mas é a mediação do presente que lhe confere significado, uma vez que seu papel é oferecer orientações para a relação com o mundo, que se dá sempre no aqui e agora. Ao menos idealmente, a investigação científica pretende chegar a um fim e, ato contínuo, oferecer conhecimentos definitivos e inequívocos do objeto a que se dedicou. A compreensão, por seu turno, almeja chegar a uma boa relação com o mundo, um resultado que é, ao contrário do científico, provisório, frágil, continuamente ameaçado pela própria dinâmica das relações entre os seres humanos e o mundo; sua transmissibilidade só é possível por meio do esforço de fixar esta relação inexata em alguma expressão durável, como em uma obra artística ou de ciência política, ou em alguma ação capaz de se fixar na memória de quem foi por ela

48 Arendt, "Understanding and Politics (The Difficulties of Understanding)" in: Essays in Understanding: 1930-1954 - Formation, Exile, and Totalitarianism. New York: Schocken Books, 1994, pp. 307-27. Existem algumas questões relevantes a respeito da edição deste texto. Cf. a nota na abertura do texto e as páginas xviii e xix da "Introduction" que Jerome Kohn elaborou para o volume.

${ }^{49}$ Cf. supra pp.29-30

50 Arendt, "Understanding and Politics" p.308 
afetado. Assim concebida, a compreensão não é uma atividade de natureza epistemológica, mas existencial, e é enquanto tal que Arendt a exerce respondendo à exigência imposta pelo seu presente.

Mas esta distinção entre compreender e conhecer não implica distanciamento completo entre as duas atividades. Elas mantêm, ao contrário, relações bastante próximas, o que explica o fato de serem frequentemente confundidas e de ser tão difícil apontar com precisão os limites entre uma e outra. Esta proximidade exige da autora o recurso a uma apresentação "esquemática e portanto necessariamente inadequada" das "três etapas" do processo de compreensão, exemplificadas aqui com a compreensão do totalitarismo. O esforço para compreender o mundo ao redor parte sempre de uma compreensão preliminar e imediata dos eventos à medida que estes se dão e, nesta situação, usam-se as ferramentas então oferecidas pelo senso comum. No caso específico da primeira reação contrária aos regimes totalitários, a luta se deu em nome da liberdade, ou seja, foi esta a palavra que organizou o sentido da luta antes que fosse possível desenvolver qualquer conhecimento científico a respeito do totalitarismo. Neste estágio, os regimes totalitários eram concebidos como uma ameaça à liberdade oriunda de um mal político, ao qual de alguma maneira se vinculavam desejo de poder, vontade de dominar, terror e outros males bastante experimentados; deve-se a esta inarticulação, por exemplo, o fato de "totalitarismo" ter sido usado, com alguma frequência e por algum tempo, como sinônimo de "imperialismo", palavra que enfeixava problemas já bastante familiares e sentidos como próximos aos trazidos pelo totalitarismo. Contra o senso comum, elabora-se propriamente o conhecimento e, no caso do totalitarismo, este apareceu sob a forma das mais variadas teorias, servindo-se de conceitos como superego, capitalismo de estado, imagem do pai, burocracia, classe média e tantos outros. Este passo contribui decisivamente para uma orientação mais segura no mundo, para a conciliação com a realidade, pois revela elementos que escapam à compreensão preliminar e organizam as ideias mantidas por ele de forma inarticulada. É graças ao conhecimento que podemos conceber as diferenças abissais entre o governo de Hitler e a partilha da África, fenômenos antes amalgamados sob uma noção difusa de "mal político", e lidar melhor com o mundo em que isto aconteceu.

No entanto, apesar de sua valiosa contribuição, o conhecimento traz consigo uma forte tentação de se afastar inteiramente das impressões iniciais, fundadas no senso comum, e se perder em um labirinto de resultados e conclusões que sempre oferece caminhos novos, mas nunca leva a lugar algum. A tendência do conhecimento é procurar os meios para atingir 
certos fins a que se propõe, de modo que, se o totalitarismo se vincula a um movimento das classes médias, faz-se necessária a dissolução das classes médias; se ele é a expressão política da estrutura do superego, faz-se necessária a reforma das relações familiares; se resulta da expansão da lógica do Estado, faz-se necessária a redução do Estado a seu mínimo. Estas conclusões são fundadas em raciocínios e estudos sérios, mas encontram uma decisiva barreira na realidade, da qual explicam apenas uma parte, embora frequentemente expressem pretensões totais.

\begin{abstract}
Caso o cientista, mal orientado (misguided) pelo próprio esforço de sua investigação, comece a posar como especialista em política e a desprezar a compreensão popular a partir da qual ele iniciou seu trabalho, ele perde imediatamente o fio de Ariadne do senso comum, o único capaz de guia-lo (guide) de modo seguro através do labirinto de seus próprios resultados. Se, por outro lado, o scholar pretende transcender seu próprio conhecimento - e não há outra maneira de conferir sentido ao conhecimento - ele deve humildemente ouvir de novo e atentamente a linguagem popular, na qual palavras como "totalitarismo" são usadas (used) como clichês políticos e abusadas (misused) como bordões, a fim de restabelecer o contato entre conhecimento e compreensão. ${ }^{51}$
\end{abstract}

A ideia de que o conhecimento surge em oposição ao senso comum é antiga e familiar a todos nós, mas este retorno ao senso comum é menos evidente e exige uma explicação a partir da polissemia e da etimologia dos termos da locução. Arendt escreve este texto em inglês e "senso comum" traduz aqui common sense, embora ela considere "muito sugestivo" o fato de os franceses chamarem-no de "o bom senso", le bon sens. ${ }^{52}$ Common, assim como "comum", pode significar, por um lado, aquilo que não tem nada de especial, que é ordinário e, por outro lado, aquilo que é de todos, que pertence a todos. Sense, por sua vez, pode ser vertido para o português como "senso" apontando para "sensatez", ou seja, para a qualidade do que é ponderado, comedido, prudente, sensato. Além disto, dada a enorme amplitude da raiz latina de onde deriva, sense também pode ser vertido por "sentido" apontando tanto para a faculdade de perceber o que está ao redor através dos cinco sentidos, quanto para a percepção de que algo está ou não está em conexão com o mundo, como quando se diz que determinada afirmação não tem sentido. É por esta variedade semântica que, em um contexto distinto, mas tratando do mesmo senso comum, Arendt recorre à forma latina, sensus communis, ${ }^{53}$ onde todos estes diferentes significados se condensam, a fim descrever uma maneira de se encaixar (to fit) no mundo que seja sensata, pois atenta ao sentido das coisas

\footnotetext{
${ }^{51}$ Arendt, "Understanding and Politics", p.311

${ }^{52}$ Arendt, "The Crisis in Culture" in: Between Past and Future, p.218.

53 O recurso se apoia em Kant. cf. Arendt, Lectures on Kant's Political Philosophy (especialmente as duas últimas lições); cf. tb. "The Crisis in Culture" in. Between Past and Future e The Life of the Mind, pp.80-92.
} 
que ocorrem ao redor e chegam até mim pelos cinco sentidos; este mundo aparece de forma imediata, ordinária, sendo portanto comum, e pertence a todos os seres humanos que nele se situam, sendo também por isto comum.

Diferentemente da consideração tradicional do que é o senso comum é algo a ser desprezado, Arendt o valoriza bastante. Não, evidentemente, para se opor à ciência esposando uma idea mistificada de "popular" ou de imediato, mas como uma maneira de não dar à ciência a última palavra, de não submeter o mundo a algum avatar de Deus. A fim de defender a importância do senso comum, Arendt recorre também aos romanos, "talvez o povo mais políticos que tenhamos conhecido",54 e, mais especificamente, a Cicero, que, em sua defesa da humanitas, afirma preferir a companhia de Platão à de seus críticos, mesmo que estes tenham razão. "O que Cícero está de fato dizendo é que, para o verdadeiro humanista, nem as verdades (verities) do cientista, nem a verdade (truth) do filósofo e tampouco a beleza do artista podem ser absolutas; o humanista, por não ser especialista, exerce uma faculdade de juízo e de gosto que está além da coerção imposta por cada especialista sobre nós." 55

Diante disto, e voltando à questão da compreensão, entendemos melhor a afirmação de que a única maneira de o cientista não se desencaminhar no labirinto da ciência, formado por inúmeros corredores muito parecidos entre si, é manter-se atado ao "fio de Ariadne oferecido pelo senso comum", que permite a volta ao mundo exterior. Deixado por si e à disposição de sua própria lógica, o conhecimento progride entre meios e fins, causas e efeitos e tende a imaginar que seu objeto constitui a totalidade do mundo, ou seja, tende a se converter em superstição. Considerando a caráter totalitário da lógica, que impõe ao pensamento um movimento determinado e alienado do tempo e do espaço, ${ }^{56}$ percebe-se a facilidade com que o conhecimento pode concluir que o mundo inteiro se encontra em movimento de necessário progresso ou a necessária danação, formando as duas superstições contra as quais, vimos acima, Arendt se coloca desde o início. Ao afirmar que pretende compreender o totalitarismo, a autora pretende conferir sentido ao que aconteceu e, para tanto, se serve da massa de informações fornecidas pelas ciências e pelos dados históricos mais concretos. "Compreensão precede e sucede o conhecimento. A compreensão preliminar, que está na base de todo conhecimento, e a verdadeira compreensão, que o transcende, têm isto em comum: tornam o conhecimento significativo." 57

\footnotetext{
${ }^{54}$ Arendt, The Human Condition, p.7

${ }^{55}$ Arendt, "The Crisis in Culture" in. Between Past and Future, p.222.

${ }^{56}$ Cf. Origens do totalitarismo, pp. 468-74.

${ }^{57}$ Arendt, "Understanding and Politics", p. 311
} 
A oposição entre compreender e conhecer aspira à valorização do sentido mundano das ações, o que torna difícil uma posição de transcendência, tão cara à filosofia e à ciência, em que o observador se retira do presente, sobrevoa o passado e se mostra capaz de profetizar o futuro. Esta postura é caracterizada por Arendt como uma déformation professionelle dos historiadores, particularmente acentuada com o surgimento das filosofias da história. A posição natural do historiador é a de quem, situado no presente, procura explicar o presente olhando para o passado, ou seja, com a tarefa de indicar onde se iniciaram e por onde se desenvolveram os processos cujo fim é o presente a partir de onde olha. Nesta experiência, o presente é tomado como problema e como medida para analisar o passado, pois é com o fim do processo em mãos que o historiador se lança à busca pelo início dos processos; em outros termos, o historiador parte dos efeitos para buscar as causas. É natural, portanto, que o historiador veja

na História (history) uma história (story) com muitos fins e nenhum início; esta inclinação se torna realmente perigosa apenas quando, por qualquer motivo, as pessoas começam a fazer filosofia a partir da história tal qual esta se apresenta aos olhos profissionais do historiador. Quase todas as explicações modernas da assim chamada historicidade do homem foram distorcidas por categorias que, quando muito, são apenas hipóteses de trabalho para organizar o material do passado. ${ }^{58}$

Esta experiência do historiador faz surgir a tentação de aplicar ao futuro os padrões observados no passado, sobretudo quando estes padrões se articulam a uma determinação muito precisa do que é o ser humano. Esta tentação é tanto maior quanto maiores são os êxitos das ciências fundadas em conhecimentos a respeito do ser humano porque eles efetivamente permitem uma maior previsibilidade do comportamento humano em diferentes níveis.

Da perspectiva arendtiana, no entanto, esta é uma maneira incompleta de encarar a linha temporal, pois o presente não é apenas o fim do passado, mas é também o início do futuro. A déformation professionelle do historiador mutila o presente precisamente no momento em que, negando-lhe o caráter duplo de sua abertura, projeta sobre o futuro tudo aquilo que viu no passado. Contra esta supressão, faz-se necessário abrir uma outra perspectiva e incluir seriamente na reflexão a potência do início contida no presente. Notemos que isto não é o mesmo que afirmar que o presente cria o futuro o tempo todo, nem que a continuidade entre passado e futuro está rompida de uma vez por todas. O novo não surge continuamente, nem a todo momento, mas, à maneira de um milagre, de modo imprevisível, ele pode surgir a qualquer momento transformando o presente em um início que 
altera profundamente a relação entre passado e futuro. "A grande importância que o conceito de início e origem tem para todas as questões estritamente políticas reside no fato simples de que a ação política, como toda ação, é essencialmente o início de algo novo; em termos de ciência política, ela é, como tal, a própria essência da liberdade humana." ${ }^{59}$ Considerando esta ruptura no tempo, o conhecimento tem pouco a oferecer a respeito do futuro, pois ele opera, literalmente, com o já conhecido, o que por definição exclui o novo. Deste ponto de vista, a relação entre conhecimento e liberdade humana é tensa, ou mesmo excludente, e é por isto que se faz necessário complementar o conhecimento com a compreensão.

Antes de iniciar o último e breve movimento do texto, dedicado ao papel da imaginação, Arendt insere aqui uma citação de Agostinho que tem importância capital em nosso contexto. Agostinho, lembremos, foi o tema de doutorado de Arendt, defendido depois de anos de estudos em teologia e filosofia, e aparece em vários outros momentos de sua obra até seu último livro, A vida do espírito, e esta citação, especificamente, aparece também em outros lugares permitindo articular não apenas os diferentes momentos de sua obra, mas também os diferentes registros em que a reflexão arendtiana opera ao mesmo tempo. A citação é retirada de um capítulo da Cidade de Deus em que um dos pais da Igreja católica se dedica ao problema da conciliação entre a perfeição da Criação e o constante aparecimento de seres novos no mundo, que pode ser resumido da seguinte forma: sendo Deus o mais perfeito dos seres, sua Criação não pode ser aperfeiçoada, o que torna o surgimento do novo um problema porque ele pode representar, por um lado, o aperfeiçoamento da obra de Deus, ideia manifestamente ímpia, ou, por outro lado, a corrupção da perfeição. Ou seja, o surgimento de um ser novo equivale a uma alteração na obra divina, o que não representa problemas sérios quando pensamos em seres inteiramente naturais, posto que eles são idênticos entre si (uma árvore é sempre uma árvore), mas exige explicações muito difíceis quando nos referimos aos seres humanos, posto que cada alma é única e insubstituível. Uma solução teológica encontrada foi afirmar que o número de almas permanece sempre o mesmo desde a criação e que não há, portanto, novidade possível ao alcance dos humanos, pois cada nascimento é, na verdade, o retorno de uma alma que já havia se libertado do corpo, já se encontrava em estado de graça e agora deve enfrentar novamente as misérias e os trabalhos da vida. Esta solução afirma um circuito eterno e composto sempre pela mesma quantidade de almas, ideia que Agostinho rejeita como ímpia:

${ }^{58}$ Arendt, "Understanding and Politics", p. 320 
Que é que há de mais conforme com a religião do que crer que a Deus não é impossível fazer novos seres que nunca antes fizera - e, numa presciência inefável, não mudar de vontade? (...) Quanto a nós, concluímos a nossa demonstração por esta alternativa:

- ou esse número [de almas] pode aumentar sempre - e então porque negar a possibilidade de que seja criado o que nunca ainda fora criado, já que o número das almas libertadas que antes não existiam, não somente não foi produzido uma vez por todas, mas também o número de almas não cessa de aumentar?

- ou então é preciso que um certo número de almas libertadas e que já não regressarão à desgraça, seja fixado e que não aumente doravante: - então, não há dúvida, também esse número, seja ele qual for, não existia no passado porque não poderia, com certeza, crescer e chegar ao seu termo se não tivesse tido um começo que antes não existia. Para que este existisse, foi, portanto, criado um homem antes que nenhum outro tenha existido. ${ }^{60}$

A argumentação de Agostinho se segue na direção de mostrar que o surgimento de todo o gênero humano a partir de um único homem, e não de vários, como no caso dos demais seres, é parte do plano divino de conferir liberdade aos seres humanos. Arendt, por sua vez, realizando um movimento muito sagaz e decisivo para a ruptura com a tradição, caminha em outra direção. Rejeitando todos os elementos propriamente teológicos da argumentação agostiniana, em especial a ideia segundo a qual Deus deu ao ser humano a vontade livre para que ele tenha poder sobre o possível, Arendt extrai da afirmação de Agostinho o elemento temporal essencialmente vinculado ao ser humano, aqui descrito como aquele que estabelece um início para interromper o eterno ciclo de idas e vindas das almas. Esta afirmação aparece, na forma de citações, em "Compreensão e política", no encerramento da segunda edição de Origens do totalitarismo, no início do capítulo dedicado à ação em $A$ condição humana e no fim de "O que é liberdade?" evidenciando a capacidade que a noção de início tem de vincular vários aspectos do pensamento arendtiano.

A primeira edição de Origens do totalitarismo saiu em 1951 e se encerrava com "Comentários conclusivos", substituídos na segunda edição por "Ideologia e terror: uma nova forma de governo", texto elaborado por Arendt em 1953, ou seja, no período em que sua pesquisa sobre Marx e a tradição estava sendo realizada. Arendt qualificou estas alterações da seguinte maneira:

No entanto, há uma adição a esta edição que talvez mude seu caráter. O livro terminava originalmente com certos "Comentários conclusivos", sugestivos, mas conscientemente inconclusivos, que são agora substituídos por um capítulo muito

${ }^{59}$ Arendt, "Understanting and Politics", p. 320-1

${ }^{60}$ Agostinho, A cidade de Deus, XII, 20 (grifo nosso). Esta é a referência dada por Arendt. No entanto, há variações nas edições, provavelmente devido às dificuldades de estabelecimento de textos antigos, de modo que, em outras edições, como a usada aqui, este trecho encerra o capítulo 21 do livro XII. (Agostinho, A cidade de Deus. Lisboa: Calouste Gulbekian, 2000, p.1137). 
menos sugestivo e muito mais teorético sobre 'Ideologia e terror: uma nova forma de governo'. Este capítulo me parece a conclusão apropriada para o livro; de um ponto de vista mais estético, no entanto, pode-se argumentar que a própria inconclusão do fim original, mostrando a extensão do envolvimento da autora e sua preparação para permanecer engajada na matéria de seu tema, era mais afinada ao estado de espírito e ao estilo de todo o livro. ${ }^{61}$

"Ideologia e terror" permaneceu como o encerramento de Origens do totalitarismo $^{62}$ e, embora seja apenas um dos treze capítulos do livro, é um dos mais importantes e estudados da obra de Arendt. Isto não se deve apenas pela tendência a reduzir a leitura da autora à terceira parte deste livro, como vimos acima, ${ }^{63}$ mas por seu caráter "menos sugestivo e mais teorético". Em nosso contexto, no entanto, o decisivo das alterações na nova edição está no "ponto de vista mais estético", responsável por revelar a mudança do "estado de espírito" trazida por este acréscimo elaborado em meio à pesquisa sobre Marx e a tradição. ${ }^{64}$ Origens do totalitarismo traz consigo o tom amargo e uma sensação de dead end que marcam uma geração de autores alemães e está presente, por exemplo, na Dialética do esclarecimento; "Ideologia e terror" estende este tom e esta sensação até o penúltimo parágrafo para, em seu último parágrafo, sintomaticamente iniciado com uma adversativa, but, realizar a mudança do estado de espírito predominante e encerrar o livro indicando uma luz para toda a escuridão tratada até então.

\begin{abstract}
Mas permanece também a verdade de que cada fim na história contem necessariamente um novo início; este início é a promessa, a única "mensagem" que o fim é capaz de produzir. Antes de se tornar um evento histórico, iniciar é a capacidade suprema do homem; politicamente, é idêntica à liberdade do homem. Initium ut esset homo creatus est - "para que haja um início, o homem foi criado", disse Agostinho. Este início é garantido por cada novo nascimento; ele é, realmente, cada homem. ${ }^{65}$
\end{abstract}

É sintomático que esta "boa nova" tenha sido incluída apenas na segunda edição do livro, ou seja, que tenha sido elaborada no momento em que Arendt passou a se ocupar do totalitarismo por um novo ângulo. É igualmente sintomático que a mesma citação de

${ }^{61}$ Este é o trecho de um texto curto escrito por Arendt para a divulgação na imprensa da segunda edição de seu livro, de 1958. O texto foi republicado em uma edição relativamente recente que traz também as "Concluding Remarks" como apêndice. Cf. Arendt, "Totalitarianism" in: ARENDT, H - The Origins of Totalitarianism. New York: Schocken Books, 2004, pp.617ss.

${ }^{62}$ Houve ainda outra edição antes do falecimento de Arendt, acrescida de um novo prefácio para cada uma das três partes do livro.

${ }^{63} \mathrm{Cf}$. Introdução

${ }^{64}$ Esta mudança de estado de espírito é notada por vários comentadores. Cf. por exemplo, Canovan, Hannah Arendt: A Reinterpretation of Her Political Thought, p.8; Duarte, $O$ pensamento à sombra da ruptura, p.87.

${ }^{65}$ Arendt, The Origins of Totalitarianism, p. 479. 
Agostinho reapareça, ligeira ampliada, em A condição humana, precisamente na primeira seção do capítulo dedicado à atividade da ação.

Agir, em seu sentido mais geral, significa tomar a iniciativa, começar (como indica a palavra grega archein, "começar", "conduzir" e, por fim, "governar"), pôr algo em movimento (que é o significado original da palavra latina agere). Os homens tomam iniciativas, são impelidos à ação porque são initium; em virtude de seu nascimento, os homens são recém-chegados, são iniciadores. [Initium] ergo ut esset, creatus est homo, ante quem nullus fuit. "Para que houvesse um início, o homem foi criado, sem que antes dele ninguém o fosse", disse Agostinho em sua filosofia política. Este começo não equivale ao começo do mundo; não é o começo de algo, mas o de alguém, que é, por sua vez, também um iniciador. Com a criação do homem, chegou ao mundo o próprio princípio do iniciar, o que, evidentemente, é apenas uma outra maneira de dizer que o princípio da liberdade foi criado no momento em que o homem foi criado, mas não antes disto. ${ }^{66}$

Esta ocorrência apresenta de modo mais preciso o "lugar do homem no cosmos" segundo Arendt, pois distingue com clareza o início encarnado pelo ser humano e o surgimento do mundo. A criação do ser humano não é o primeiro ato da Criação, uma vez que foi antecedida pela criação de toda a natureza e suas temporalidades. Disto decorre que o nascimento representa a chegada de um ser humano em um mundo que já está aí e que certamente permanecerá quando este ser humano desaparecer. Ou seja, embora cada nascimento encarne o princípio do início, este início se dá no interior de algo já dado, já organizado em sua forma própria, o que vincula quem chega a quem já está, a quem já passou e, evidentemente, a quem vai chegar. Isto tudo aparece explicitamente na outra ocorrência da citação, encontrada no quarto e último movimento do ensaio "O que é liberdade?", onde Arendt adiciona ainda a novidade que sua própria leitura significa para a tradição:

... encontramos em Agostinho não apenas a discussão da liberdade como liberum arbitrum, embora esta discussão tenha se tornado decisiva para a tradição, mas também uma noção de liberdade concebida de modo inteiramente diferente que aparece, característicamente, em seu único tratado político, De Civitate Dei. Como era de se esperar, na Cidade de Deus Agostinho fala mais a partir do pano de fundo (background) das experiências especificamente romanas do que em qualquer outro de seus escritos, de modo que a liberdade é aí concebida, não como uma disposição interna ao homem, mas como uma característica da existência humana no mundo. $\mathrm{O}$ homem possui a liberdade à medida que ele, ou melhor, que sua chegada ao mundo, se equipara ao surgimento da liberdade no universo; o homem é livre porque ele é um início e foi criado quando o universo já havia sido criado. (...) No nascimento de cada homem, este começo inicial (initial beginning) é reafirmado porque em cada caso algo novo chega em um mundo já existente e que continuará a existir depois da morte de cada indivíduo. Porque é um começo, o homem pode iniciar; ser humano e ser livre são uma única coisa. Deus criou o homem a fim de introduzir no mundo a faculdade do início: liberdade. ${ }^{67}$

Assim como a tradição, Arendt vai a Agostinho para teorizar a liberdade.

${ }^{66}$ Arendt, The Human Condition, p. 177 (grifo nosso). 
Diferentemente da tradição, no entanto, ela não encontra a liberdade no livre arbítrio, disposição interna ao ser humano que se exterioriza como liberdade, mas precisamente naquilo que aparece quando os humanos estão no mundo, quando o âmbito das relações humanas se atualiza. Esta concepção é claramente contrária à noção de liberdade negativa sem ser exatamente uma liberdade positiva, uma vez que, como veremos à frente, o espaço entre os humanos, necessário para a efetivação da liberdade, não está permanentemente constituído e existem inúmeras atividades significativas que são feitas fora dele.

A centralidade da breve afirmação de Agostinho para o pensamento de Arendt está, a nosso ver, no cruzamento entre o problema "metafísico" do tempo e o problema "antropológico" do humano. Interpretado por Arendt, Agostinho revela algo de fundamental a respeito do ser humano ao apontar, não para uma essência ou uma definição, mas para uma característica sustentada em sua relação com o tempo: Deus criou o ser humano para que este iniciasse novos processos. Deus já havia criado processos ao criar a natureza, o mundo, o cosmos, mas nenhum destes entes criados é capaz de iniciar por si mesmo algo significativo, algo que já não estivesse previsto pela ordem divina. A circularidade dos movimentos planetários e dos ciclos biológicos expressa bem as temporalidades anteriores à criação do humano, caracterizadas pela eterna repetição do mesmo em intervalos regulares; em contraste evidente com todas elas, há este seres singulares e irrepetíveis, que por isto mesmo trazem sempre algo novo à circularidade característica da Criação.

Este uso particularmente perspicaz da afirmação teológica de Agostinho forneceu a Arendt um caminho para a formulação do novo pensar político. Como ela aponta explicitamente, a ideia agostiniana segundo a qual Deus deu ao ser humano a vontade livre para que ele tenha poder sobre o possível é uma ideia tradicional e deve ser tomada como tal. No entanto, dando um passo à frente na ruptura com a tradição, Arendt realizando um belo movimento interpretativo e mostra que a liberdade não estava ali onde Agostinho imaginava estar (na vontade livre), mas em outro lugar, em um ponto visível a partir da análise de uma estrutura temporal extraída do mesmo autor, capaz de fornecer uma outra ideia de liberdade desprovida de elementos tradicionais que ainda persistem na Preocupação com a política no pensamento filosófico europeu contemporâneo. Esta distinção entre o tempo propriamente humano, o do início, e outras temporalidades é especialmente importante porque é ela que permite distinguir, por um lado, o que há de determinável nos humanos e pode, portanto, ser

${ }^{67}$ Arendt, "What is Freedom?" in. Between Past and Future, p.165-6. (grifos nossos) 
apreendido como objeto do conhecimento, como coisa e, por outro lado, aquilo que resiste essencialmente à apreensão total por parte do logos. Em outras palavras, é esta distinção que permite elaborar um pensar político distanciado da noção de natureza humana e fundado na de condição humana. Com este astuto cruzamento entre início e liberdade, Arendt realiza a "mudança de registro" notada por Ricoeur e constrói, não a ponte, mas o túnel entre Origens do totalitarismo, um livro de política, e A condição humana, um livro de filosofia fundamental. 


\section{Parte II: o novo pensar em atividade}

A condição humana resulta deste esforço de lidar com o problema do totalitarismo a partir de uma nova perspectiva. Ele se originou, como vimos, na insuficiência da análise do totalitarismo soviético em Origens do totalitarismo, que conduziu Arendt ao problema dos elementos totalitários no marxismo. Este movimento sofreu uma inflexão quase imediatamente e, em função de uma antiga suspeita, conduziu a pesquisa para o problema dos vínculos entre o totalitarismo e a tradição, que se mostraram presentes no procedimento de fundar uma filosofia política sobre uma definição do ser humano. Assim, informada pelo debate alemão que desde os anos 1920 se ocupou da quarta questão kantiana e pelo debate francês em torno do humanismo, Arendt elabora à sua maneira a questão do humano a fim de contribuir para o rompimento da tradição permitindo um novo pensar político. Confrontandose com autores contemporâneos, ela se viu diante de enormes avanços realizados na direção de um novo pensar político, mas notou ainda resquícios de elementos tradicionais que exigiram dela uma radicalidade maior, à altura da radicalidade da ameaça nova que o século XX portava.

Se a instituição central do totalitarismo é o campo de concentração, concebido como um laboratório em que a dominação total do ser humano se concretizou tornando real a hipótese de que "tudo é possível", inclusive a transformação da personalidade humana em mera coisa; se a tradição conservou em si a pressuposição de que o logos pode abarcar e conhecer totalmente o ser humano por inteiro e esta pressuposição participa da hipótese central do totalitarismo; então, uma das tarefas do pensamento político a ser elaborado diante destas novíssimas perplexidades é incluir em si uma reflexão séria e profunda a respeito daquilo que há no humano e que pode oferecer alguma resistência à dominação total. Ou, para usar a formulação precisa de Ricoeur a respeito do gesto contido em $A$ condição humana, Arendt procura pensar a partir da hipótese inversa à de que tudo é possível e, para tanto, busca pelos traços mais duráveis da condição humana, aqueles que não são possíveis de serem alterados sem que se deixe de ser humano.

Tanto o caráter inédito e recente do totalitarismo quanto a firmeza com que Arendt se decide pela ruptura com a tradição devem nos impedir de considerar que o caminho arendtiano nos conduz a uma nova antropologia, a uma repetição do esforço de finalmente definir de uma vez por todas o ser humano. Arendt não pretende enfrentar o problema do totalitarismo estabelecendo filosoficamente a natureza humana, mas oferecendo uma descrição de traços da condição humana. Arendt sabe que uma natureza humana solidamente 
ancorada em um fundamento não cabe mais na situação pós-tradicional em que seu pensamento se insere, mas sabe também que a questão a respeito do humano não perdeu sua pertinência. Muito ao contrário, é precisamente porque a tradição se rompeu que se torna urgente pensar novamente certas questões tão antigas quanto a filosofia, dentre as quais a que se refere à natureza do humano.

No prólogo do livro, encontramos a reafirmação do totalitarismo como um problema ao qual se vinculam a atividade da compreensão e a importância de abordar a condição humana:

Este livro não oferece uma resposta a estas preocupações e perplexidades. Estas respostas são oferecidas todos os dias e são assunto da política prática, estão sujeitas ao acordo entre muitos; elas nunca podem se basear em considerações teóricas ou na opinião de uma pessoa, como se se tratasse aqui de problemas para os quais apenas uma solução fosse possível. O que eu proponho no que se segue é a reconsideração da condição humana a partir do vantajoso ponto de vista de nossas mais novas experiências e nossos mais recentes medos. Obviamente, isto é uma questão de reflexão, e a irreflexão - a imprudência temerária, a confusão irremediável ou a repetição complacente de "verdades" que se tornaram triviais e vazias — parece-me estar entre as características marcantes de nosso tempo. O que eu proponho, portanto, é muito simples: nada mais do que refletir sobre o que estamos fazendo. ${ }^{68}$

A tarefa é realizada em três movimentos organizados em seis capítulos. No primeiro capítulo, a autora apresenta seu tema e, sobretudo, a posição a partir de onde enxerga a questão. Em seguida, no movimento que se estende do capítulo dois ao capítulo cinco, há uma análise das "mais elementares articulações da condição humana" ${ }^{69}$ apoiada no espaço em que se realizam (capítulo 2) e no tempo que as organiza (capítulos 3, 4 e 5). Estes dois movimentos constituem a "reconsideração da condição humana" que sustenta a "reflexão sobre o que estamos fazendo" realizada no último capítulo, intitulado "A vita activa e a era moderna".

\section{Vita activa e o tempo}

Logo na primeiríssima página, Arendt apresenta, de modo estranhamente axiomático, as três atividades humanas cujas análises constituem a maior parte do livro. Trabalho (labor/Arbeit), fabricação (work/Herstellen) e ação (action/Handeln) são descritos como "atividades fundamentais", status alcançado pela correspondência entre cada uma delas e uma das condições básicas da condição humana; o trabalho corresponde à vida; a fabricação, à mundanidade; a ação, à pluralidade. Em mais de uma ocasião ao longo do livro, Arendt deixa

${ }^{68}$ Arendt, The Human Condition, p.5 - grifos nossos. 
clara sua recusa de oferecer uma lista e uma análise exaustivas das atividades que compõem a vita activa ${ }^{70}$ e afirma que seu esforço consiste em "tentar determinar, como algum grau de segurança, seu significado político." ${ }^{71}$ Diante disto, a primeira questão que surge é: por que estas atividades e não outras?

Uma primeira tentativa de resposta pode nos conduzir à declaração explícita no texto de que trabalho, fabricação e ação são fundamentais porque correspondem a condições básicas sob as quais a vida humana foi dada aos humanos. Esta resposta, no entanto, apenas nos conduz à pergunta sobre o que significa "condições básicas" e nos desencaminharia em questões relativas a níveis de profundidade das atividades e condições, o que por sua vez remeteria a alguma essência que serviria de ponto a partir do qual medir a distância e a "profundidade" de cada condição. É fato que a natalidade e a mortalidade são descritas como "as condições mais gerais da existência humana", o que parece estabelecer alguma anterioridade destas em relação aquelas, mas tanto a recusa do procedimento essencialista quanto a própria formulação destas e de outras passagens - como aquelas em que a Terra aparece como a quintessência da condição humana ou "apenas" uma das condições ${ }^{72}$ — nos dissuadem de procurar alguma ordem ou hierarquia exatas das várias condições que formam a condição humana.

Não é sem razão que muitos intérpretes enxergam na formulação arendtiana a influência da distinção entre poiesis (fabricação) e praxis (ação) feita por Aristóteles. Como se sabe, na Ética a Nicômaco, Aristóteles distingue as duas atividades afirmando, entre outras coisas, que a fabricação resulta em um objeto distinto da própria atividade, ao passo que a ação se encerra em si mesma; o fabricante e o resultado de sua atividade são separados ou têm naturezas diferentes, enquanto o agente e a ação são inseparáveis. Como atestam vários intérpretes, ${ }^{73}$ a compreensão da relação entre Arendt e Aristóteles exige referência a Heidegger, e por pelo menos duas razões. Em primeiro lugar, porque Arendt - além de Marcuse e Leo Strauss, segundo Benhabib ${ }^{74}$ - foi profundamente marcada pela apropriação

\footnotetext{
${ }^{69}$ Arendt, The Human Condition, p. 5

${ }^{70}$ Cf. p. ex. p. 10 e 78.

${ }^{71}$ Arendt, The Human Condition, p. 78

72 Arendt, The Human Condition, p.2 e p.11, respectivamente

${ }^{73} \mathrm{Cf}$. Taminiaux, "D'Aristote au bios politikos et à la thêoria tragique" in. La fille de la Thrace et le penseu professionnel, pp.115-53; Villa, The Fate of the Political, pp.17-41, 42-52; Benhabib, The Reluctant Modernim of Hannah Arendt, pp.114-8; "Aristoteles" in. Heuer et alii, Arendt Hanbuch.

${ }^{74}$ Cf. Benhabib, The Reluctant Modernism of Hannah Arendt, pp.114-5
} 
feita por Heidegger do pensamento aristotélico e, em segundo lugar, porque o gesto destrutivo contra a tradição exige afastamentos fundamentais de Aristóteles. Isto forma um quadro complexo em que o peso atribuído à apropriação ou à destruição influi decisivamente na compreensão da autora. Uma leitura mais "apropriativa" ganhou impulso a partir de Habermas, para quem "[A] principal obra filosófica de Hannah Arendt (The Human Condition, 1958) tem por objeto uma renovação sistemática do conceito aristotélico de praxis", ${ }^{75}$ do que decorre comumente a afirmação de que Arendt participa de um movimento neoaristotélico preocupado com os destinos do propriamente político em uma modernidade tão disposta a se submeter à técnica.

Uma leitura mais "destrutiva", com a qual nos alinhamos, enfatiza a distância entre Arendt e a tradição estabelecendo limites mais estreitos aos vínculos entre ela e Aristóteles. Segundo Villa, a afirmação de que Arendt é uma neoaristotélica, muito comum nas disputas entre "liberais" e "comunitaristas", termina por domesticar a autora impedindo-nos de ver aquilo que ela traz de mais radical, a saber, sua revisão profunda da filosofia política e, consequentemente, da ação política. Diante do que vimos a respeito da relação entre Arendt e a tradição, é bastante difícil imaginar que ela, aqui ou em qualquer outro ponto de sua obra, esteja procedendo qualquer espécie de "renovação", de modo que nos parece mais acertada a afirmação de que a teoria arendtiana da ação

\begin{abstract}
procura realizar uma reconceituação radical da ação procedendo, em parte, por meio de uma crítica e uma transformação da praxis aristotélica. A insistência de Habermas de que o projeto de Arendt é o de uma "renovação" nos faz perder de vista este fato. De modo mais geral, se Arendt "recupera" elementos da tradição ocidental da teoria política, ela o faz a fim de melhor superar esta tradição." ${ }^{176}$
\end{abstract}

Seguindo na mesma direção, Taminiaux também considera que Heidegger é fundamental na leitura arendtiana de Aristóteles. Para ele, Heidegger procurou na Ética a Nicômaco fundamentos existenciais para o bios theoretikos e, pressupondo uma solução de continuidade entre Platão e Aristóteles, terminou por considerar que este apenas clarificou a ontologia do Dasein implícita na luta de Platão contra os velamentos cotidianos - como, por exemplo, a doxa, que esconde a verdade. Na avaliação de Taminiaux, o resultado deste esforço de Heidegger é uma leitura bastante inovadora, marcada, por um lado, pela capacidade de revelar as contribuições de Aristóteles para o pensamento pós-metafísico que Heidegger pretende elaborar e, por outro, pela manutenção do tradicional privilégio

\footnotetext{
${ }^{75}$ Habermas, "El concepto de poder de Hannah Arendt", p.209

${ }^{76}$ Villa, Arendt and Heidegger, p.4.
} 
concedido ao bios theoretikos. Depois de minuciosa análise de certos temas — o discurso, o par idion e koinon, a aparência, a oposição entre imortalidade e eternidade e a dynamis Taminiaux conclui ser possível "dizer que A condição humana opõe a esta reapropriação especulativa de Aristóteles, uma reapropriação integralmente praxeológica", ${ }^{77}$ ou seja, livre do privilégio tradicionalmente concedido ao bios teoretikos. Por uma leitura "destrutiva", portanto, percebemos que Arendt não recupera Aristóteles, como quer Habermas, mas se reapropria dele a partir de uma reapropriação radical feita por Heidegger, de modo que, neste seu passo, ela mantém o afastamento heideggeriano com relação à metafísica e, indo além na tarefa da ruptura, retira a estrutura tradicional presente no desprezo pela praxis mantido por Heidegger. $^{78}$

Outra dificuldade de considerar Arendt uma neoaristotélica está no caráter teleológico do pensamento de Aristóteles, que o conduz à definição do ser humano a partir da vida na polis, e, como bem mostra Villa, à universalização da experiência da fabricação, que encoraja a consideração de que todo o cosmos está organizado em termos de meios e fins. ${ }^{79}$ Além disto, como indicaremos rapidamente à frente, os conceitos arendtianos de ação e liberdade se aproximam da esfera do contingente afastando-se da esfera do possível, onde Aristóteles - e com ele toda a tradição, incluindo Agostinho - localizou a praxis. ${ }^{80}$

Diante disto, parece-nos mais acertado proceder de outra maneira e vincular a escolha destas três atividades — trabalho, fabricação e ação — ao problema do totalitarismo e ao desenvolvimento deste problema no percurso de Arendt analisado até aqui. Este vínculo se torna bastante visível se nos lembrarmos que o surgimento da questão do humano se deu na metáfora dos campos de concentração como laboratórios em que até mesmo a personalidade humana é transformada em coisa e nos conduziu à afirmação de que o procedimento de definir o ser humano por meio de sua differentia specifica é um traço totalitário da tradição. A consequência imediata desta descoberta é a necessidade de formular uma nova maneira de pensar o humano e a política capaz de conjugar os elementos do ser humano que são perfeitamente definíveis àqueles que resistem à definição. Em outros termos, um pensar que associe conhecimento e compreensão do humano.

\footnotetext{
77 Taminiaux, La Fille de la Thrace et le penseur professionnel, p.115; cf. tb. pp.24-6

${ }^{78}$ Cf. Villa, The Fate of the Political, pp.211-40.

${ }^{79}$ Cf. Villa, Arendt and Heidegger, pp.49-52

${ }^{80}$ Adriano Correia elaborou uma crítica cuidadosa da "Arendt de Habermas" a partir de um ponto de vista um tanto distinto. Cf. Correia, "O caso do conceito de poder - a Arendt de
} 
Neste ponto, a afirmação de Agostinho interpretada por Arendt mostra toda a sua força, pois, sob a ideia de que o humano representa um início em contraposição à temporalidade dos demais elementos da Criação, subjaz a ideia de que diferentes temporalidades organizam certos aspectos do ser. No caso do complexo ser humano, é possível detectar várias temporalidades distintas se cruzando e parece ser esta a razão pela qual, na breve e aparentemente arbitrária apresentação das atividades contida na primeira página de A condição humana, cada uma das atividades e suas condições é imediatamente vinculada a uma temporalidade que lhe é própria. A vida é descrita aqui como "o processo biológico do corpo humano" organizado em "crescimento, metabolismo e declínio final" e formando, portanto, um movimento circular iniciado e terminado no nada. Em contraste com este caráter cíclico da vida, a fabricação é descrita aqui precisamente como o que escapa ao ciclo vital, ou seja, como aquilo que se destina a "durar e transcender" as vidas individuais que abriga. Cada uma à sua maneira, as condições da vida e da mundanidade se conectam à "condição mais geral da existência humana: nascimento e morte, natalidade e mortalidade. (...) No entanto, dentre as três atividades, a ação é a que tem a conexão mais próxima com a condição humana da natalidade; o novo início inerente a cada nascimento pode se fazer sentir no mundo apenas porque os recém-chegados possuem a capacidade de iniciar algo novo, isto é, de agir." ${ }^{81}$ Deste ponto de vista, o misterioso verbo "corresponder" (correspondlentsprechen), com que Arendt vincula condições e atividades, significa "organizar-se sobre a mesma temporalidade".

A frase de Agostinho analisada anteriormente é reafirmada aqui de duas maneiras. Por um lado, conserva-se aqui a ideia de uma convergência entre a ação e o início, expressa ipsis litteris na Cidade de Deus; por outro, e de modo mais significativo, revela-se um vínculo essencial entre o humano e o tempo capaz de permitir uma melhor elaboração das articulações no interior da vita activa e, consequentemente, uma "reconsideração da condição humana". Esta maneira de proceder apoiada sobre as temporalidades dispensa o recurso a categorias tradicionais como "essência" ou ao procedimento de procurar a differentia specifica do ser humano e transforma-la em fundamento da filosofia; ela permite, portanto, a realização da tarefa de pensar adequadamente o humano e a política "a partir do vantajoso

Habermas" in: Hannah Arendt e a modernidade, pp.159-74.

${ }^{81}$ Arendt, The Human Condition, p. 8-9. Neste caso, como em vários outros, a edição alemã do livro ganha significativamente em precisão. Nela, birth and death [nascimento e morte] foram vertidos pela própria Arendt como durch Geburt zur Welt kommt und durch Tod aus ihr wieder verschwindet [vir ao mundo pelo nascimento e, pela morte, dele desaparecer 
ponto de vista de nossas mais novas experiências e nossos mais recentes medos", dentre os quais está a possibilidade de considerar a espontaneidade humana como uma coisa.

A elaboração desta reconsideração da condição humana se organiza em dois grandes movimentos. Por um lado, Arendt realiza a dissolução do resultado do procedimento essencialista que marca a tradição e, por outro, introduz de modo decisivo o indeterminado no pensar político. $\mathrm{O}$ aspecto determinado do ser humano é tratado, como era de se esperar, a partir da definição do humano apresentada por um dos filósofos rebeldes que nos servem de guia para o passado, a saber, Marx. Analisando a noção marxista do humano, que representa o "ápice e o fim da tradição", Arendt revela duas temporalidades distintas no interior da atividade do trabalho e nos faz ver que, ali mesmo onde Marx acreditava haver apenas trabalho, há trabalho e fabricação. O indeterminado no humano surge logo em seguida, no momento em que Arendt desenvolve a afirmação de que o ser humano é essencialmente início, ideia basilar de seu conceito de ação, que encerra a lista de atividades analisadas apresentando um quadro em que aspectos determinados e indeterminados do ser humano aparecem de modo articulado.

A fim de justificar a radicalidade e a consequente estranheza de seu ponto de vista, Arendt explicita sua posição de exterioridade com relação à tradição na segunda seção do primeiro capítulo. O tema da hostilidade mútua entre filosofia e política se reapresenta aqui vinculado a uma discussão a respeito da tradicional superioridade da vita contemplativa sobre a vita activa, fundada por Platão e Aristóteles e posteriormente vulgarizada pelo cristianismo. Arendt argumenta que a utopia presente na filosofia política platônica não apenas é dirigida pelo insight superior do filósofo, mas tem, além disto, sua finalidade última na construção de um mundo em que o modo de vida do filósofo se torne possível. Mesmo Aristóteles, ao apresentar e articular os distintos modos de vida, é guiado pelo ideal da contemplação uma vez que se refere especificamente a três modos de vida que podem ser escolhidos livremente, ou seja, que não são impostos pela necessidade; as vidas atribuladas levadas pelo comerciante e pelo escravo estão excluídas por princípio aqui. A superioridade da contemplação diante da ação se acentuou com o fim da polis e a difusão do cristianismo, de modo que toda forma de engajamento com o mundo, incluindo a ação e os cuidados com a cidade, prezadas por Aristóteles, aos poucos passou a ser considerada também uma incômoda necessidade que afasta os humanos da forma verdadeiramente livre de vida, a contemplação.

novamente]. 
Como vimos anteriormente, Arendt não pretende ser a primeira a questionar esta hierarquia. Ela mesma afirma reiteradas vezes que este é um dos esforços da filosofia mais recente, que avançou significativamente na direção de romper com a tradição. No entanto, "apesar das aparências, esta situação não foi essencialmente alterada pela ruptura moderna com a tradição e a nem com a reversão final da hierarquia realizada por Marx e Nietzsche", ${ }^{82}$ como provam os impasses a que chega o elogio da ação feito pelos existencialistas franceses. A proposta arendtiana é radicalizar a ruptura beneficiando-se dos avanços já realizados pelos filósofos rebelados contra a tradição e pelos filósofos contemporâneos que permaneceram na mesma trilha. Esta radicalidade, no entanto, não deve ser tomada como uma recusa da diferença entre vita contemplativa e vita activa. As experiências do pensar, do querer e do julgar são essencialmente distintas das experiências do trabalhar, do fabricar ou do agir e a negação desta diferença mais atrapalha do que ajuda na compreensão da condição humana e na formulação do novo pensar político. O ponto, para Arendt, está na ideia de superioridade de uma sobre a outra, seja na versão tradicional, em que a vita contemplativa é superior à vita activa, seja na versão moderna e invertida, que vemos em Marx e nos existencialistas franceses.

\begin{abstract}
A inversão moderna partilha com a hierarquia tradicional a premissa de que uma mesma preocupação humana central deve prevalecer em todas as atividades dos homens, uma vez que, sem um princípio abrangente, nenhuma ordem poderia ser estabelecida. Esta premissa não é evidente e meu uso do termo vita activa pressupõe que a preocupação subjacente a todas as atividades da vita activa não é a mesma, não é superior nem inferior à preocupação central da vita contemplativa.$^{83}$
\end{abstract}

Esta superioridade também se expressa em termos temporais e exige de Arendt, na última seção deste primeiro capítulo, uma distinção entre eternidade e imortalidade. Voltando uma vez mais ao início da tradição, a autora argumenta que os gregos tinham a experiência da mortalidade no contraste com a imortalidade dos deuses, da natureza, do cosmos. Diferentemente de todas as coisas, que realizam um movimento temporal circular e portanto não morrem, o tempo da vida individual do ser humano se configura como uma linha reta que começa no nascimento e inapelavelmente termina com a morte. Assim, se há alguma grandeza possível para os humanos, ela está na habilidade de fabricar coisas - obras, atos e palavras - duráveis, capazes de encontrar seu lugar neste cosmos em que tudo é imortal, exceto os seres humanos. Esta constatação fundamenta o agon característico da vida política grega, contra o qual Sócrates e Platão se colocam depois de descobrirem a existência de

\footnotetext{
${ }^{82}$ Arendt, The Human Condition, p. 17.

${ }^{83}$ Arendt, The Human Condition, p. 17
} 
ideias, que, diferentemente do cosmos, não são imortais, mas eternas. Esta descoberta foi realizada no momento em que a polis, expressão maior da grandeza possível aos mortais, declinava revelando suas poucas chances de alcançar a imortalidade, ou sequer a estabilidade. Estas duas experiências - o declínio da polis e a descoberta do eterno - conduziram Sócrates e Platão a atribuir superioridade ao eterno fazendo surgir a theoría como atitude que dá acesso às ideias e diante da qual a luta terrena por imortalidade aparece como vanglória e vaidade. A outra grande experiência de declínio de obra humana, a queda de Roma, somada à ascensão do cristianismo e a consequente vulgarização da experiência do eterno em detrimento do imortal, consolidou este arranjo fundador da tradição. ${ }^{84}$

Assim como a vita contemplativa se sobrepôs à vita activa ao longo da tradição, também a eternidade exerceu o papel de metro com o qual as ações humanas devem ser julgadas. Um rompimento radical com a tradição deve incluir, portanto, a recusa da superioridade do eterno, a ser realizada pela apreciação da "luta pela imortalidade, originalmente situada na fonte e no centro da vita activa." 85

\section{Trabalho, fabricação, determinação}

A dissolução do conceito marxista de ser humano se inicia no capítulo três do livro, que se abre com uma nota explicativa dedicada a apresentar a relação de Arendt com Marx. Se considerarmos a situação da autora, refugiada alemã, crítica da URSS radicada nos EUA e escrevendo na época do macarthismo, a nota nos faz lembrar as palavras com que Nietzsche se apresenta no prólogo de Ecce homo: "Ouçam! pois eu sou tal e tal. Não me confundam, sobretudo!" ${ }^{86}$ Sem hesitar na crítica a Marx, Arendt se coloca firmemente à distância daquilo que ela qualifica como antimarxismo profissional, característico da época, formado especialmente por quem durante muito tempo se serviu da "enorme riqueza das ideias e insights de Marx"87 e agora o despreza, desqualificando até mesmo sua vida pessoal. Se Marx tem que ser criticado aqui, é precisamente por ele ter sido grande, de modo que a crítica está muito mais vinculada ao esforço de alcança-lo do que ao gosto de tentar diminui-lo. ${ }^{88}$

Um elemento decisivo nesta diferença entre Arendt e os antimarxistas está no fato de

\footnotetext{
${ }^{84}$ Cf. Taminiaux, La Fille de la Thrace et le penseur professionnel, pp.122-4

${ }^{85}$ Arendt, The Human Condition, p. 21

${ }^{86}$ Nietzsche, Ecce homo, §1, Tradução de Rubens Rodrigues Torres Filho.

${ }^{87}$ Arendt, The Human Condition, p. 79

${ }^{88}$ Cf. tb. Arendt, "The Ex-Communists" in: Essays in Understanding, pp.391-400. Sobre o significado de "grandeza" aqui, cf. Amiel, A não-filosofia de Hannah Arendt, p.123.
} 
sua crítica a Marx ganhar sentido no interior de sua tarefa de desmontagem da tradição, não na defesa da "ordem ocidental". De fato, a preocupação com Marx surge da questão do totalitarismo, que, de maneira distinta, também anima os antimarxistas; no entanto, como vimos, Arendt ampliou rápida e decisivamente sua preocupação para toda a tradição, contra a qual já mantinha suspeitas, dando um passo que os antimarxistas jamais pretenderam dar. $\mathrm{O}$ procedimento arendtiano diante de Marx não consiste em analisar extensa e detidamente cada detalhe, aquilatar cada variação, explorar os significados de cada nuance ou fazer um balanço abrangente da fortuna crítica; quase ao contrário disto, Arendt insere Marx em sua ideia de tradição localizando-o precisamente como um filósofo rebelado contra a tradição e que, portanto, serve de guia para o passado auxiliando a desmontagem da tradição.

Como vimos acima, A Ideologia alemã de Marx e Engels fundamenta o materialismo histórico e toda a filosofia política marxista afirmando que o ser humano é um animal que se distingue dos demais por meio do trabalho, ou seja, tem sua differentia specifica no trabalho. Uma vez que o trabalho é aqui concebido como uma relação com a natureza, a atividade essencialmente humana é definida como um movimento em direção à natureza. Este movimento é impulsionado pela necessidade e retira o ser humano de si lançando-o a determinada parte da natureza capaz de satisfazer sua necessidade. Seguindo as leis da dialética, o ser humano volta a si completando o movimento metabólico tão logo sua necessidade é satisfeita. Como o ponto de partida e o ponto de chegada estão no mesmo lugar, no ser humano, este movimento pode ser adequadamente descrito como circular e, além disto, porque ele é impulsionado pela necessidade e pela vida, ele obedece à direção e ao ritmo da vida interrompendo-se no momento em que a vida termina.

No entanto, como se sabe, o movimento aqui descrito não realiza um círculo perfeito, uma vez que ele inevitavelmente promove alterações tanto no ser humano quanto na natureza. Marx e Engels o caracterizam como metabolismo porque, quando volta a si depois de ter saído de si em direção à natureza, o ser humano já não é mais o mesmo que saiu de si. Como a natureza também se altera neste contato, é possível afirmar que o trabalho transforma a natureza em uma "segunda natureza", que por sua vez transforma o ser humano em um "segundo ser humano". O movimento aqui descrito, no entanto, não se resume a um único círculo, pois as necessidades humanas não são inteiramente satisfeitas em um único lançar-se à natureza, de modo que a atividade do trabalho descrita por Marx é composta também pela sequência formada por estes vários movimentos circulares. As mudanças promovidas pelo ser humano na natureza e pela natureza no ser humano se acumulam com o passar do tempo e 
ultrapassam o período de vida de um determinado indivíduo formando uma outra temporalidade, subjacente às sucessivas passagens da primeira natureza para a segunda (e consequentemente, do primeiro humano para o segundo). Este acúmulo de mudanças forma um movimento de direção única, uma linha reta que se movimenta sempre em frente estruturando a história.

Tomando o tempo como ponto de vista, descobrem-se assim duas temporalidades imbricadas no conceito marxista de ser humano; uma circular, em que o ser humano retorna a si; outra reta, formada pelo acúmulo das mudanças promovidas pelo movimento humano. Deste ponto de vista, percebe-se com clareza que a atividade do trabalho, em Marx, caminha em dois sentidos diferentes, algo de que ele mesmo estava perfeitamente consciente. "O primeiro pressuposto de toda a história humana é, naturalmente, a existência de indivíduos humanos vivos. (...) Toda historiografia deve partir desses fundamentos naturais e de sua modificação pela ação dos homens no decorrer da história." 89 Por um lado, o trabalho ganha sentido pela existência de indivíduos humanos vivos, ou seja, pelo atendimento às necessidades impostas pela vida; por outro, o trabalho também ganha sentido pelas mudanças realizadas no decorrer da história, ou seja, pela fabricação de um mundo que ultrapassa a vida, que permanece e acolhe inúmeros ciclos vitais no decorrer da história. Este ponto de vista dissolve completamente o conceito marxista de ser humano e de trabalho porque, ao revelar dois sentidos distintos, exige uma distinção do conceito em duas atividades igualmente distintas; no vocabulário arendtiano, elas se chamam trabalho (labor/Arbeit) e fabricação (work/Herstellen).

Arendt sabe que a distinção por ela aqui proposta é "incomum", mas, indicando um critério que norteia seu pensamento, insiste na separação porque "a evidência fenomênica em seu favor é impressionante demais para que ela seja ignorada". ${ }^{90}$ Sua análise das evidências fenomênicas das atividades humanas conta com o apoio do "testemunho obstinado e muito articulado" oferecido por todas as línguas europeias, que insistem desde a antiguidade em manter duas palavras etimologicamente desvinculadas para se referir a cada uma destas atividades.

Assim, a língua grega distingue entre ponein e ergazesthai; a latina, entre laborare e facere ou fabricare, que têm a mesma raiz etimológica; a francesa, entre travailler e ouvrer; a alemã, entre arbeiten e werken. Em todos estes casos, apenas os equivalentes para "trabalho" (labor) têm uma conotação inequívoca de dores e penas. O alemão Arbeit se aplicava originalmente apenas ao trabalho agrícola executado por servos, não à fabricação realizada pelo artesão, chamada de Werk. O francês

${ }^{89}$ Marx \& Engels, A ideologia alemã, p. 87 - grifos nossos.

90 Arendt, The Human Condition, p. 79 
travailler substituiu o mais antigo labourer e é derivado de tripalium, um tipo de tortura. $^{91}$

A origem do termo português "trabalho" é igual à do francês travailler, como bem notam Adriano Correia e Celso Lafer, e se adequa perfeitamente à argumentação. ${ }^{92}$ Esta passagem de $A$ condição humana, localizada no início da análise das atividades humanas, é especialmente importante porque nela Arendt evidencia uma estratégia fundamental para o novo pensar político a ser desenvolvido. Se a tradição "borrou as distinções e articulações no interior da vita activa"93 porque abordou a vita activa sempre do ponto de vista da vita contemplativa, ou seja, se a primazia do filósofo sobre o político impediu a preocupação filosófica séria com o que se passa no interior da caverna ou no interior do hospício, faz-se necessário distinguir as atividades humanas que foram por tanto tempo negligenciadas e compreender suas articulações. ${ }^{94} \mathrm{~A}$ análise da temporalidade das atividades, como acabamos de ver, é de grande auxílio nesta tarefa.

Ao levar a sério a "evidência fenomênica" das distinções entre as atividades, Arendt não pretende ser a primeira a tê-la percebido, mas a primeira a pensá-la livre do peso da tradição. Locke pensou a diferença entre trabalho e fabricação em termos de "o trabalho de nossos corpos e a obra de nossas mãos"; 95 Smith, em termos de trabalho produtivo e improdutivo, distinção sobre a qual Marx também se apoia, mas supera em benefício da distinção entre trabalho concreto e trabalho abstrato, explicitada no segundo ponto do conhecido capítulo sobre a mercadoria que abre $O$ capital e se chama "Duplo caráter do trabalho representado nas mercadorias".

\begin{abstract}
Todo trabalho (Arbeit) é, por um lado, dispêndio de força de trabalho do homem no sentido fisiológico, e nessa qualidade de trabalho humano igual ou trabalho humano abstrato gera o valor da mercadoria. Todo trabalho é, por outro lado, dispêndio de força de trabalho do homem sob forma especificamente adequada a um fim, e nessa qualidade de trabalho concreto útil produz valores de uso. ${ }^{96}$
\end{abstract}

Parte do esforço de expressar esta distinção é exigido pelo fato de Marx usar exclusivamente o termo Arbeit e é por isto que Engels, ao editar a quarta edição de $O$ capital

\footnotetext{
${ }^{91}$ Arendt, The Human Condition, p.80 n.3

${ }^{92} \mathrm{Cf}$. Correia, "Nota à nova edição brasileira" in: Arendt, $A$ condição humana, p. VI e Lafer, "A trajetória de Hannah Arendt", in. Pensamento, persuasão e poder. p. 28-9. Cf. tb. CalvetMagalhães, "A categoria de trabalho (labor) em Hannah Arendt", pp.6-7

${ }^{93}$ Arendt, The Human Condition, p. 17.

${ }^{94}$ Arendt se refere expressamente a essas articulações também em: id. ibid p.78, 85, 141, 225 e 316

${ }^{95}$ Arendt, The Human Condition, §11

${ }^{96}$ Marx, O capital, p. 53
} 
alguns anos depois da morte de Marx, adicionou a seguinte nota a esta passagem:

A língua inglesa tem a vantagem de possuir duas palavras distintas para estes dois aspectos diferentes do trabalho (Arbeit). O trabalho que gera valores de uso e é qualitativamente determinado chama-se de work, em oposição a labour; o trabalho que cria valor e é medido apenas quantitativamente chama-se labour, em oposição a work. ${ }^{97}$

A distinção entre trabalho abstrato (labour) e trabalho concreto (work) oferecida por Marx e Engels se vincula expressamente à produção de valor realizada por cada um deles; o trabalho abstrato produz valor de mercadoria, ao passo que o trabalho concreto produz valor de uso. Considerando que esta oposição entre valor de mercadoria e valor de uso será superada em benefício da forma geral de valor ${ }^{98}$ e esta por sua vez se converterá na forma dinheiro, a noção de trabalho também será conduzida a uma forma única, donde a suficiência de um único termo, Arbeit.

Ao proceder desta maneira, Marx se mostrou capaz de encontrar no trabalho o denominador comum ao qual considera possível reduzir todas as atividades humanas. Este esforço de chegar ao elemento fundamental é especialmente visível em seu trabalho tardio, considerado como "mais científico e menos filosófico", mas ele está presente em toda sua filosofia. De fato, este interesse se mostra de modo mais evidente apenas a partir de certo ponto de sua trajetória, o que levou Althusser ao seu famoso "corte epistemológico", contra o qual muitos reagiram afirmando a impropriedade de exagerar a importância desta ruptura. Do ponto de vista arendtiano, no entanto, a diferença entre o "Marx jovem" e o "Marx velho" quase desaparece porque em todos os momentos ele se mostra um filósofo tradicional, uma vez que, apesar de sua rebeldia, o peso da vita contemplativa sobre a vita activa está presente precisamente neste esforço de reduzir a multiplicidade das atividades humanas ao uno que se pode apreender, totalizar e conhecer; esforço está presente aqui, em $O$ capital, mas também se encontra na definição de ser humano realizada em sua obra de juventude.

Como vimos anteriormente, a relação entre Arendt e o conhecimento não é a da recusa. O novo pensar político por ela realizado não pretende negar o papel da ciência, elaborada por pensadores como Marx, mas submete-la ao processo de compreensão, responsável por encaixar no mundo os conhecimentos científicos elaborados no espírito. Esta é uma das razões pelas quais Arendt toma a direção exatamente oposta à de Marx e, em vez de reduzir work e labour a Arbeit, desdobra o Arbeit de Marx em seus conceitos de labor e

\footnotetext{
97 Id. Ibid.

${ }^{98}$ Marx realizará este movimento algumas páginas à frente da citada; Engels, ao falar do labour aqui, já não usa nenhum qualificativo para "valor".
} 
work.

Ao analisar as "evidências fenomênicas", Arendt nota a existência de uma atividade destinada ao atendimento das necessidades impostas pela biologia; com base no "testemunho obstinado e articulado" oferecido pelas línguas europeias, confere a esta atividade o nome de trabalho. Assim, em Arendt, o trabalho é a atividade organizada sob a mesma temporalidade da vida, condição que os humanos partilham com absolutamente tudo aquilo que é vivo, do que decorre a impossibilidade de, a partir do trabalho, distinguir individualmente cada humano. Enquanto animal laborans, o ser humano se define como espécie humana e só se distingue de outras espécies naquilo que se refere às necessidades específicas de alimentação, repouso, proteção do frio etc. Estes cuidados exigidos pela natureza conduzem a tarefas anônimas, uma vez que não singularizam, e repetitivas, posto que a natureza funciona em ciclos. Além disto, como a vida se sustenta sobre o corpo e este é necessariamente uma unidade, sua manutenção remete os seres humanos para dentro de si mesmos, onde se encerram durante o processo de produção e consumo que caracteriza a vida do animal laborans. Para manter vivo o corpo de que é responsável, o trabalho não precisa fabricar objetos de uso, mas gerar produtos de consumo, destinados ao desaparecimento tão logo absorvidos pelo organismo. No reinício do ciclo, a volta desta necessidade satisfeita uma vez exige outro processo idêntico de produção e consumo, que assim se movimenta enquanto houver vida.

Uma das características da temporalidade circular é sua previsibilidade. Por se apresentar como um movimento que parte de determinado ponto e em seguida volta a este mesmo ponto, a temporalidade circular é marcada por uma regularidade que permite prever seus próximos movimentos. Tudo aquilo que se organiza sob esta temporalidade é, portanto, passível de ser apreendido pelo conhecimento, como nos mostram há muito tempo as ciências naturais e, há menos tempo, mas também com inegáveis progressos, as ciências humanas. Mesmo quando direcionadas ao humano, as ciências naturais, como a medicina, não encontram dificuldades fundamentalmente distintas de quando lidam com objetos não humanos, como a botânica. No caso das ciências humanas, o quadro é mais complexo porque seu sucesso exige, em alguma medida, a pressuposição de que seu objeto está estruturado exclusivamente sobre a temporalidade circular. A Economia Política, por exemplo, avançou consideravelmente quando foi capaz de identificar, com o auxílio da noção de interesse, a regularidade do comportamento humano no plano econômico. Seu poder heurístico é inegável e sustenta análises, programas de governo, previsões de ações futuras, 
planejamentos. Apesar disto, no entanto, não é raro vermos erros monumentais cometidos pelos melhores economistas e planejadores, o que se deve, em grande medida, à impossibilidade de reduzir os seres humanos à regularidade de seus interesses. Mesmo a mais fina das análises está sujeita ao fracasso devido ao surgimento de algo novo ou à persistência de algo antigo.

Diante deste tipo de dificuldades, a tendência da ciência é confiar na superação destas dificuldades com o auxílio a uma ciência superior, capaz de incorporar o fracasso atual no sucesso futuro. Do ponto de vista arendtiano, trata-se de dobrar a aposta na pressuposição de que a temporalidade circular organiza o humano, se não totalmente, ao menos naquilo que mais importa. Marx se revela um pensador tradicional também neste ponto. Em seus primeiros escritos, afirmou ao lado de Engels que o comunismo é o movimento real que supera o estado de coisas atual conduzindo-nos a um estado de coisas futuro em que há "a possibilidade de hoje fazer isto, amanhã aquilo, de caçar pela manhã, pescar à tarde, à noite dedicar-me à criação de gado, criticar após o jantar, exatamente de acordo com a minha vontade, sem que eu jamais me torne caçador, pescador, pastor ou crítico." 99 Anos mais tarde, sob o impacto das derrotas sofridas pelos movimentos de trabalhadores, em especial na França em 1848, Marx redobraria a aposta na instauração deste estado de coisas, mas agora com o auxílio de uma ciência econômica superior, apresentada em $O$ capital.

Assim como em Arendt, o trabalho em Marx também se impõe aos seres humanos pela existência de indivíduos vivos. Ambos convergem também na ideia de que o trabalho consiste em um movimento que remete os seres humanos a si mesmos - afinal, a vida se assenta, em última instância, sobre a unidade do corpo. No entanto, embora ambos aceitem a afirmação de que o esforço do trabalho contém algo de repetitivo, eles discordam aqui em um ponto fundamental porque Marx faz com que este movimento repetitivo extrapole o âmbito estritamente natural do ser humano quando o converte naquilo que o define. Arendt, por sua vez, graças à distinção entre trabalho e fabricação, circunscreve a temporalidade circular à vida impedindo a obliteração das demais temporalidades, o que lhe a identificação de uma contradição marxista entre a afirmação de que o trabalho decorre das necessidades impostas pela vida e a de que o desenvolvimento desta atividade conduzirá a um estado de coisas em que será possível agir "exatamente de acordo com a minha vontade", ou seja, livre da necessidade. Embora esta contradição entre necessidade e liberdade talvez possa habilmente ser dissolvida com o auxílio da dialética, "[P]ermanece o fato de que em todos os estágios de

${ }^{99}$ Marx \& Engels, A ideologia alemã, p. 38 
sua obra, ele [Marx] define o homem como um animal laborans e então o conduz a uma sociedade em que a maior e mais humana das forças do homem não é mais necessária." 100

Aos olhos de Arendt, esta contradição flagrante não revela uma fragilidade do pensamento de Marx, mas uma decorrência de sua posição de rebelde contra a tradição. Trata-se de uma das derrotas autoinfligidas (self-defeat) a que nos referimos anteriormente. "Contradições flagrantes e fundamentais como esta raramente ocorrem em autores de segunda categoria, nos quais podem ser relevadas. Na obra de grandes autores, elas conduzem ao próprio centro de seu trabalho e são a pista mais importante para a verdadeira compreensão de seus problemas e insights." ${ }^{101}$ Embora invertida, a hierarquia tradicional entre vita contemplativa e vita activa permanece operando no pensamento de Marx, como tão bem resume a última de suas teses sobre Feuerbach, que convoca a superação da filosofia pela política. A tradição permanece ainda no procedimento tipicamente filosófico e mantido por Marx de procurar pelo que é essencial, mesmo quando em detrimento de "evidências fenomênicas". Um dos resultados desta situação foi esta espécie de superação do humano colocada à maneira de uma utopia, um reino da liberdade sem qualquer necessidade, o que constitui uma contradição existencial e permite a Arendt levantar a seguinte pergunta: "Se o trabalho é a mais humana e a mais produtiva das atividades do homem, o que acontecerá quando, depois da revolução, 'o trabalho for abolido' no 'reino da liberdade', quando o homem conseguir se emancipar do trabalho? Qual atividade produtiva e essencialmente humana sobrará?" ${ }^{102}$ Do ponto de vista arendtiano, uma situação de total liberação da necessidade equivaleria à superação da condição humana da vida, o que aparece como uma insolúvel contradição existencial. ${ }^{103}$

100 Arendt, The Human Condition, p.105
101 Arendt, "Tradition and Modern Age", p.24
102 Arendt, "Tradition and Modern Age", p.23-4
103 O desejo de superar a necessidade é uma aspiração humana desde tempos imemoriais;
já Hesíodo reclamava da faina em O trabalho e os dias e no mito bíblico o trabalho aparece
como castigo divino. Ao longo da modernidade, o antigo sonho de superar a necessidade
pareceu realizável graças ao desenvolvimento de ciências e técnicas, do que resultou a
formulação de utopias de vários tipos. Esta fantasia, é forçoso reconhecer, sobreviveu ao
suposto "fim das utopias" do século XX, pois ela parece animar muito das novas ciências
biomédicas há algum tempo e, mais recentemente, parece ter ganhado força com os
desenvolvimentos das tecnologias de informação.
No romance Ubik, publicado em 1969, Philip K. Dick imaginou uma empresa que lucrava
muito oferecendo, na forma de serviços, a possibilidade de manter pessoas falecidas em
estado de "meia-vida", ou seja, com os corpos conservados artificialmente em certas bolsas
e com sua atividade cerebral artificialmente mantida, para eventual contato com quem
permeneceu vivo. Em dado momento, o dono da empresa afirma:
"Quando eu me for, Herbert Schonheit von Vogelsang disse a si mesmo, acho que pedirei, 
Esta contradição revela as dificuldades enfrentadas pelo pensamento tradicional quando este deve lidar com perplexidades novas, revelando a urgência da levar a ruptura às últimas consequências. Como vimos acima, a dissolução da noção marxista de trabalho em duas atividades distintas, realizada por meio da explicitação de duas temporalidades igualmente distintas, se insere neste movimento de ruptura da tradição. Munida da distinção entre trabalho e fabricação, foi possível a Arendt distinguir também as condições correspondentes a cada uma destas atividades. Se o trabalho corresponde à vida, a fabricação corresponde à mundanidade do ser humano, ou seja, à capacidade humana de criar objetos que resistem ao tempo cíclico característico da vida. A apresentação dos conceitos de mundo e de fabricação foi feita, como mostramos, pela indicação da durabilidade, uma temporalidade frontalmente oposta à da vida.

Importa notar de saída que esta separação entre vida e mundo não conduz, em absoluto, à transformação da vida em fundamento de uma nova filosofia política. Marx, quando vinculou a existência de indivíduos vivos ao curso da história, tornou difícil a posição liberal, burguesa, que tomava o indivíduo como o centro da história e o fundamento da filosofia política. Arendt, por sua vez, ao separar o que Marx juntara, não recolocou a vida individual no lugar do fundamento da filosofia política. Ela não retornou à posição liberal. Muito ao contrário, como vimos anteriormente, todo seu esforço intelectual se lança contra a ideia de conceder a qualquer conteúdo determinado o status de fundamento e seria um contrassenso primário conferir esta função à vida e ao trabalho. De fato, Arendt leva a sério a

em testamento, que meus herdeiros me revivam um dia por século. Assim, poderei observar o destino de toda a humanidade." Mas isso representava um custo de manutenção muito alto para os herdeiros - e ele sabia o que isso queria dizer. Mais cedo ou mais tarde eles se revoltariam, tirariam seu corpo da bolsa térmica e - Deus o livre - o enterrariam.

- Enterro é barbárie - Herbert resmungou em voz alta. - Reminiscência das origens primitivas de nossa cultura.

Apesar de sua prodigiosa imaginação, Dick não concebeu a possibilidade de desvincular a vida e o corpo, e é sintomático que poucas décadas depois Charlie Brooker tenha imaginado, para o episódio "San Junipero" da série de televisão Black Mirror, uma história em que a vida, ou algo remotamente parecido com isto, é mantida sem nenhum vínculo com o corpo graças à transformação da memória individual em dados armazenados em dispositivos eletrônicos no interior dos quais as pessoas podem "viver" fora do tempo e em um lugar maravilhoso inteiramente fabricado por softwares. Para dar verossimilhança a sua história, Dick a fez se desenrolar em um futuro relativamente próximo, 1992, artifício desnecessário a Brooker, que conta sua história de modo plausível em um cenário perfeitamente reconhecível por quem vive hoje em países de capitalismo avançado, o que evidencia nossa caminhada nesta direção. É também bastante significativo - e irônico, se pensarmos que Marx também imaginou uma superação da vida - que, embora a série tenha sido escrita por um autor inglês, o cenário perfeito para a vida artificial seja muito semelhante à Califórnia, berço do Vale do Silício e sede do estágio mais avançado do 
experiência da individualidade e do distanciamento entre indivíduos. Sua distinção entre a solidão (loneliness) e o estar só (solitude), realizada no contexto de sua análise das massas, bem como suas reflexões sobre a atividade do pensar não deixam dúvidas a este respeito; mesmo em seu conceito de ação a individualidade desempenha um papel. Em nenhum destes casos, no entanto, individualidade é tratada como expressão da condição humana da vida; ao contrário, como vimos, a vida é incapaz de singularizar os seres humanos, pois estes, enquanto seres vivos, pertencem todos a uma mesma espécie. Aliás, a crítica arendtiana à sociedade contemporânea, apresentada na última parte de A condição humana, critica duramente a crença muito difundida de que a vida é o bem supremo do ser humano. Esta crítica se vincula, consequentemente, à preocupação com a elevação do trabalho ao mais alto nível de importância entre as atividades humanas. A "sociedade de empregados" (jobholders) que Arendt enxerga nos EUA dos anos 1950 está intimamente vinculada a um movimento realizado ao longo da modernidade e que contou com a contribuição tanto de liberais quanto de socialistas.

\begin{abstract}
A repentina e espetacular ascensão do trabalho, da mais baixa e desprezada posição, para o nível de mais importante e estimada das atividades humanas, começou quando Locke descobriu que o trabalho é a fonte de toda propriedade. Ela foi adiante quando Adam Smith afirmou que o trabalho era a fonte de toda a riqueza e encontrou seu ápice no 'sistema de trabalho' de Marx, no interior do qual o trabalho se tornou a fonte de toda produtividade e a própria expressão da humanidade do homem. ${ }^{104}$
\end{abstract}

A oposição entre vida e mundo tampouco conduz à desconexão completa entre trabalho e fabricação. Ao descrever as atividades tomando como eixo a temporalidade subjacente a elas, Arendt indica com firmeza os sentidos distintos que orientam cada uma delas. Enquanto trabalham, os seres humanos efetivam o amor e a responsabilidade pela vida; quando fabricam, efetiva o amor e a responsabilidade pelo mundo. A vida, no entanto, se passa dentro do mundo e este, por sua vez, foi criado por indivíduos vivos, de modo que a distinção entre vida e mundo, trabalho e fabricação é decisiva, mas não estanque. "No que se refere à coisa, produto final da fabricação, o processo [de fabricação] não precisa se repetir [depois de a coisa estar pronta]. O impulso em direção à repetição vem ou da necessidade que o artesão tem de ganhar seus meios de subsistência, e neste caso sua fabricação coincide com seu trabalho, ou da demanda por multiplicação no mercado, e neste caso o artesão que deseja atender a esta demanda acrescentou ao seu ofício a arte de ganhar dinheiro, como disse 
Platão." ${ }^{105}$ Seria contrariar inteiramente as "impressionantes evidências fenomênicas" negar as relações entre duas atividades que, lembremos, toda a tradição considerou como parecidas ou mesmo idênticas. Estas duas condições e atividades se distinguem em suas temporalidades, mas se unificam em seu enraizamento na condição humana. O humano é o locus em que elas se cruzam e é por isto que a compreensão da condição humana se realiza pela descrição das articulações fundamentais que ocorrem no interior da vita activa.

A fabricação é uma atividade especificamente humana e esta passagem do natural ao humano é indicada pelo recurso ao termo homo faber, que surge por oposição ao animal laborans e designa o ser humano enquanto construtor do mundo. $\mathrm{O}$ tempo da atividade do homo faber é limitado e definido pelo próprio fabricante, que parte de uma ideia (começo) e se serve de determinados meios em direção à obra acabada (fim). O processo de fabricação exige o recurso à técnica e a ferramentas, que são, elas mesmas, objetos fabricados. Assim como a produção de bens de consumo, a criação de uma obra se dá no espaço privado, no isolamento da oficina, onde o fabricante se relaciona com a técnica e com sua própria capacidade de executá-la. No entanto, diferentemente dos produtos de consumo, destinados à manutenção do próprio corpo do animal laborans, o objeto fabricado se destina ao mundo em que será inserido a fim de ser usado por quem participa deste mundo. Assim, a fabricação revela uma responsabilidade pelo mundo, ao passo que o trabalho revela uma responsabilidade pela vida.

A oposição da fabricação com relação à vida se revela também no próprio movimento de converter a natureza em material. Para, por exemplo, obter madeira, o fabricante precisa matar uma árvore retirando-a de seu ciclo natural e aplica sobre ela os procedimentos necessários para que ela se converta em madeira e seja capaz de durar indefinidamente. Este afastamento do ciclo natural é tanto maior quanto maior é a distância com relação à natureza, ou seja, quanto mais humanizado está o objeto criado com este material. Dado o caráter constante e expansivo da vida, esta distância do objeto humano com relação à natureza não é assegurada de uma vez por todas e se vincula, não apenas ao processo de fabricação, mas também ao uso que se faz do objeto fabricado. "Deixada por si mesma ou descartada do mundo humano, uma cadeira se tornará novamente madeira, e a madeira se decomporá retornando ao solo, de onde surgiu a árvore antes de ser cortada e transformada em material sobre o qual se fabrica e com o qual se constrói." ${ }^{106}$ Ou seja, o distanciamento entre o mundo

${ }^{105}$ Arendt, The Human Condition, p. 143

${ }^{106}$ Arendt, The Human Condition, p.137 
e a vida é variável e se apoia na relação que os seres humanos mantém com o mundo, seja para construi-lo, seja para usá-lo.

Assim, vida e mundo também se opõem no que se refere ao tipo de relação que demandam dos humanos. O consumo, inteiramente ligado às necessidades biológicas, se lança aos produtos do trabalho e faz com que desapareçam tão logo entrem em contato com o organismo a cuja manutenção se destinam. O uso, por sua vez, relaciona os humanos a objetos duráveis, que permanecem depois deste contato, de modo que o uso de objetos reforça sua participação na durabilidade e, ainda que ele possa desgastar um determinado objeto, ele termina por reforçar e reafirmar a própria artificialidade humana, pois, com ele, os seres humanos evitam que os objetos sejam "deixados por si mesmos ou descartados do mundo humano".

É nestes termos, de oposição entre vida e mundo, trabalho e fabricação, que Arendt realiza sua crítica a fenômenos modernos tão distintos quanto a automação e a cultura de massas. A automação é concebida como a absorção da artificialidade pelo processo vital, uma vez que a máquina, diferentemente da ferramenta e dos instrumentos, é fabricada com o intuito de emular o movimento do corpo humano acelerando-o à máxima velocidade permitida pela técnica disponível. Embora a máquina seja fabricada pelo homo faber, ela segue as demandas do animal laborans, que não se interessa pela construção de um mundo, mas pela redução das dores de seu trabalho e pelo aumento dos produtos dele resultante. Esta fabricação "realizada sob o modo do trabalho" ${ }^{107}$ se afasta muito pouco da circularidade da vida, uma vez que a máquina ganha sentido na realização de uma vida melhor e deve ser "descartada do mundo humano" tão logo surja outra máquina, capaz de realizar a mesma tarefa com maior velocidade e eficácia. ${ }^{108}$

Do mesmo modo, a cultura de massas é compreendida como resultado da absorção da durabilidade pelo tempo circular, o que leva Arendt a conceber a própria expressão "cultura de massas" como uma contradição. O termo cultura deriva do latim colere e remete originalmente aos cuidados com o solo a fim de prepara-lo para a habitação humana. Não se trata de controle e domínio, mas de zelo e preservação animados por um amor ao lugar em que se constrói a própria habitação. Embora o termo tenha origens na relação entre o ser humano e a natureza, ele indica uma separação entre os dois, na medida em que um campo

${ }^{107}$ Arendt, The Human Condition, p.146

108 Cf. Arendt, The Human Condition, 144-59 
cultivado é distinto de um campo natural. A sociedade de massas, por outro lado, é concebida como o resultado do predomínio do animal laborans sobre todas as demais dimensões do da existência, do que decorre que sua atividade fundamental é o trabalho, organizado em momentos de produção e consumo eternamente alternados. À faina produtiva deve-se seguir um descanso e a cultura de massas é precisamente a fabricação de certos objetos destinados a este momento da temporalidade circular do animal laborans. Por considerar que a vida é uma das condições que formam a condição humana, Arendt não vê problemas no entretenimento como forma de reposição das energias gastas no processo produtivo. O que gera a preocupação da autora e a leva à crítica da cultura de massas é a absorção de obras do mundo por este ciclo natural.

\begin{abstract}
Evidentemente, não estou me referindo à distribuição em massa. Quando livros ou reproduções de imagens são lançadas no mercado a preços baixos e alcançam altos índices de vendas, a natureza do objeto em questão não é afetada. Mas sua natureza é afetada quando os próprios objetos são alterados - reescritos, condensados, digeridos, reduzidos ao kitsch em reproduções ou em preparações para filmes. Isto não significa que a cultura se alastra pelas massas, mas que a cultura está sendo destruída para produzir entretenimento. O resultado disto não é desintegração (disintegration), mas decomposição (decay) e quem promove isto ativamente não são os compositores da Tin Pan Alley, mas um tipo especial de intelectuais, frequentemente cultos e bem informados, cuja única função é organizar, disseminar e alterar objetos culturais a fim de persuadir as massas de que Hamlet pode ser tão entretecedor quando My Fair Lady, e talvez igualmente educativo. Há muitos grandes autores do passado que sobreviveram a séculos de esquecimento e abandono, mas é ainda uma questão aberta se eles conseguirão sobreviver a uma versão para entretenimento daquilo que têm a dizer. ${ }^{109}$
\end{abstract}

Entre o fim de 1996 e o início de 1997, alguns milhões de pessoas se entretiveram bastante com uma versão para cinema de Romeo e Julieta. Se Shakespeare dependesse deste filme para permanecer conosco, nós já não contaríamos com ele, pois, já em 1997, Titanic arrebatou espectadores no planeta inteiro fazendo esquecer o hit anterior, antes de ser superado por Armageddon no ano seguinte e assim sucessivamente. O gosto pessoal de Arendt a direcionava para a dita "alta cultura", o que rende anedotas deliciosas, mas não deve nos conduzir à conclusão de que sua obra esposa uma concepção "elitista" de cultura. $\mathrm{O}$ problema fundamental, não apenas no que se refere à cultura, mas à modernidade como um todo, é a absorção do mundo pela temporalidade circular do trabalho. Isto não é um problema porque o animal laborans é o que há de mais "baixo" no ser humano, mas porque ele representa apenas um dos vários aspectos da condição humana e, por estar vinculado à necessidade, tende a nos fazer obliterar todos os demais.

${ }^{109}$ Arendt, "The Crisis in Culture" in: Between Past and Future, p.204 
Neste processo de absorção de todas as atividades pelo trabalho, a oposição entre mundo e vida é reduzida em benefício desta e em detrimento do mundo, do que resulta que a experiência da durabilidade perde muito de seu sentido. Diferentemente dos produtos de consumo, os objetos fabricados permanecem depois de usados, do que decorre certa independência com relação aos seres humanos. De fato, o mundo é fabricado por humanos e não existiria sem eles, mas ele não se reduz a eles precisamente porque sua temporalidade própria, a durabilidade, confere-lhe uma autonomia e uma resistência à vida. As palavras testemunham esta resistência, uma vez que "objeto" vem de objectu, que no latim clássico significava "ato de pôr à frente, de opor, obstáculo, barreira"; em alemão, a ideia é ainda mais evidente, pois Gegenstand significa literalmente "estar contra". Assim, tudo aquilo que dura e é feito para o mundo resiste à vida, de modo que "[S]em um mundo entre homens e natureza, há um movimento eterno, mas não há objetividade."110

A durabilidade resulta ainda na sedimentação de objetos que vão ficando enquanto os ciclos vitais se passam. Este progressivo acúmulo de intervenções humanas na natureza contribui decisivamente para a composição da linha da história e abre uma relação com os seres humanos do passado, que construíram o mundo do presente, e com os do futuro, que receberão os objetos já fabricados e em fabricação. Enquanto o uso e a durabilidade de um determinado objeto permitirem sua presença no mundo, ele seguirá como uma condição dos seres humanos que frequentam a parte do mundo em que ele está inserido. Tomando a durabilidade como critério, os objetos mais mundanos e menos naturais são as obras de arte, inteiramente desvinculadas do processo de manutenção da vida e capazes de aspirar à imortalidade que lhes permite seguir condicionando incontáveis gerações por vir.

Esta maneira de condicionar os humanos também distingue a vida e o mundo, o trabalho e a fabricação no que se refere à determinação e à indeterminação dos seres humanos. Por corresponder à condição de ser vivo, partilhada por todos os humanos, o trabalho é igualmente exigido de todos eles, o que, em estreita conexão com as determinações da natureza, possibilita a previsibilidade e a universalização destas exigências tornando possível o conhecimento desta condição humana e permitindo a existência e a eficácia de ciências como a medicina, a economia e a sociologia, bem como a perigosa possibilidade do domínio biopolítico. $\mathrm{O}$ aspecto indeterminado do trabalho, por outro lado, é estreito porque se vincula simplesmente à maneira pela qual estas exigências são atendidas para cada corpo ou mesmo grupo de corpos; restringe-se à habilidade para se relacionar com o clima, aos hábitos

${ }^{110}$ Arendt, The Human Condition, p.137 
alimentares, ao lugar na cadeia produtiva, à capacidade de prover o necessário, de administrar os ganhos, de buscar salários maiores, de gozar do lazer.

A fabricação, por sua vez, tem uma relação diferente com a determinação e a indeterminação, dado que é perfeitamente possível passar a vida inteira sem produzir nada de durável, nada capaz de participar da construção da linha reta da história, nada destinado à sedimentação na civilização e na cultura. Por outro lado, no entanto, é a fabricação que coloca ao nosso redor os objetos com os quais nos relacionamos, o que inclui edifícios, talheres, satélites, livros, meios de transporte, sinfonias e todos os demais produtos derivados do engenho humano e dotados de durabilidade, de modo que o mundo condiciona os seres humanos em larga medida, uma vez que é muito diferente existir antes ou depois da invenção da internet, antes ou depois da obra de Freud, da fissura do átomo, da ocupação da lua, do Renascimento. Apesar disto, no entanto, este condicionamento jamais consegue ser absoluto, pois a relação entre os seres humanos e o mundo se dá sempre por meio da abertura que o mundo oferece a cada um. Objetivamente, por assim dizer, o mundo é vasto e uno, mas existencialmente ele é múltiplo e tem o tamanho da relação, sempre variável e em algum grau oposta à vida, que é com ele estabelecida. Consequentemente, o "polo subjetivo", por assim dizer, é também constituinte desta relação e impede a determinação completa da objetividade fazendo com que o condicionamento do mundo, embora decisivo, não tenha o mesmo caráter de necessidade que tem a determinação decorrente da vida. A capacidade de adicionar novos objetos ao mundo é um bom exemplo desta forma de condicionamento, uma vez que o homo faber deve, por um lado, levar em consideração aquilo que já existe no mundo para definir qual objeto será adicionado e, por outro, fazer o objeto brotar do próprio engenho, que é fundamentalmente separado do mundo.

Estes dois tipos de condicionamento ou determinação causaram uma série de dificuldades para a filosofia política tradicional. Estas dificuldades aparecem de modo particularmente evidente no filósofo rebelde que representa o ápice e o fim da tradição e cuja definição de ser humano deu ocasião para o desenvolvimento destas análises. Um dos grandes temas tanto da filosofia de Marx quanto da enorme escola filosófica fundada por sua obra é precisamente a maneira e o grau de determinação e condicionamento que a natureza e o mundo exercem sobre o humano. Muita tinta já correu e certamente ainda correrá a fim de discutir a tensão contida em uma de suas mais conhecidas afirmações: "Os homens fazem a sua própria história; contudo, não a fazem de livre e espontânea vontade, pois não são eles quem escolhem as circunstâncias sob as quais ela é feita, mas estas lhes foram transmitidas 
assim como se encontram." ${ }^{111}$ Como se sabe, esta afirmação está na abertura de em uma das principais análises políticas realizadas por Marx, não em sua obra de ciência. No entanto, porque procede à maneira tradicional, Marx se esforça também aqui para conhecer a ação humana, para aprimorar o trabalho do logos lançado sobre o objeto por ele definido. Seu enorme êxito revela a existência de padrões e permitiu o desenvolvimento de sólidos conhecimentos a respeito do comportamento humano.

No entanto, como vimos ao longo desta tese, há um problema fundamental no pressuposto materialista segundo o qual os seres humanos são definidos pela produção de suas condições de vida e, ainda que em uma análise fina e cuidadosa com a atribuição de determinações, aquilo que há de indefinido no humano fica necessariamente fora do pensamento marxista. Mostrando-se exímio escritor, Marx apoia a exposição de sua análise em metáforas teatrais capazes de revelar que, por trás de cada um dos inúmeros personagens que atuam naquela peça, existe um roteiro definido que seria encenado de maneira muito parecida mesmo se todos os atores fossem trocados. Arendt não discordaria da existência de um roteiro capaz de determinar muito da atuação dos atores; o que ela não aceita é que com isto seja possível apreender a totalidade dos agentes, ou sequer aquilo que é mais significativo em sua ação. Sempre sobra algo e o combate ao totalitarismo passa pela admissão séria disto que sobra.

\section{Ação, indeterminação}

Assim, para completar seu quadro da vita activa, Arendt soma uma terceira temporalidade às duas encontradas no interior da essência do ser humano tal qual descrita por Marx. Esta terceira temporalidade da vita activa torna evidente o sentido de uma atividade estreitamente vinculada ao indeterminado, e que portanto não poderia ser inteiramente revelada na análise de uma essência, de uma determinação. Ela se ancora na escuridão da alma humana, naquilo que Agostinho chamou de grande profundum que habita cada um de nós e é inalcançável pelo conhecimento. Arendt aborda a questão logo no início de $A$ condição humana, quando se lança ao problema do quem:

\footnotetext{
... se temos uma natureza ou essência, então é certo que apenas um deus poderia conhece-la e defini-la, e o primeiro pré-requisito seria sua capacidade de falar de um "quem" como se fosse um "o que". A perplexidade está em que os modos da cognição humana aplicáveis a coisas com qualidades "naturais" — o que inclui nós mesmos, na medida em que somos exemplares da espécie mais desenvolvida da vida
}

${ }^{111}$ Marx, $O 18$ de brumário de Luís Bonaparte, p.25 
orgânica — fracassam quando levantamos a questão: quem somos? ${ }^{112}$

O tema da alma é antigo e foi tradicionalmente abordado como elemento que escapa aos sentidos, que se localiza na insondável interioridade humana. Arendt, por sua vez, o aborda de modo distinto e, recusando o esforço para determinar o recôndito do abismo que habita o ser humano, considera a alma no espaço das aparências, no lugar onde ela se faz visível por meio de elementos de difícil apreensão, como o semblante, o tom de voz, o olhar, os atos, as palavras. A condição mais fundamental para que este abismo ganhe uma aparência é a presença de outros humanos. Em primeiro lugar, porque não há aparência quando não há ninguém para ver. Em segundo lugar, porque, quando se considera a presença de pessoas a partir do ponto de vista da alma de cada pessoa, nota-se de saída a existência de uma diferença fundamental entre cada um dos humanos presentes, ou seja, nota-se que nenhuma pessoa é idêntica a qualquer outra. Esta constatação elementar não conduz Arendt ao esforço de conhecer o conteúdo da alma de ninguém, mas à consideração séria do significado desta diferença revelada quando, e apenas quando, seres humanos estão diante de outros seres humanos fazendo vir à tona a diferença que singulariza cada um deles.

Desta forma, a alma de cada indivíduo se converte em singularidade no momento mesmo de sua revelação, pois, ao contrário da alma, que pode existir fechada em si mesma, a singularidade só é possível de ser pensada no interior da relação com o diferente, na medida em que o aparecimento do singular só é possível por meio da diferença. Desta necessidade do outro, decorre que o humano, enquanto singular, não existe sozinho, sem os demais para atualizar sua singularidade, de modo que a revelação da singularidade só tem sentido no interior de uma pluralidade. É por esta razão que Arendt descreve a ação, a terceira atividade da vita activa, como um processo que se inicia com a revelação do agente, ou seja, pelo surgimento de uma singularidade em uma rede plural. Diferentemente do trabalho, que corresponde à reação às necessidades impostas pela biologia, e da fabricação, estreitamente vinculada ao mundo dentro do qual passamos a existência, a ação não tem origem em nada passível de ser apreendido a priori e oferece, portanto, uma resistência ao esforço de conhecimento e apreensão total do ser humano.

Para que a pluralidade possa se efetivar, deve haver um espaço-entre (inbetween/Zwischen) humanos, formado pela presença de pessoas e sendo, portanto, essencialmente variável em função da quantidade e da posição das pessoas envolvidas.

${ }^{112}$ Arendt, The Human Condition, p.10-1. 
Evidentemente, um objeto ou uma instituição podem oferecer certa estabilidade a este espaço - como uma mesa, que relaciona e separa quem está à sua volta; ou uma tribuna, que separa quem fala e quem ouve —, mas ele é fundamentalmente indefinível porque pode não apenas variar de acordo com o objeto presente, mas prescindir inteiramente do intermédio de coisas formando-se sempre que houver pessoas juntas e desaparecendo sempre que essas pessoas se separarem. Assim, embora a pluralidade se ancore ontologicamente na escuridão da alma humana, onde se situa a vontade, não é possível pensa-la adequadamente recorrendo à noção de essência humana, uma vez que a pluralidade corresponde ao "fato de que os homens, não o Homem, vivem na Terra e habitam o mundo."113 Tampouco o modelo oferecido por Jaspers, do diálogo entre Eu-Você é suficiente, pois se trata de um espaço formado pelas múltiplas perspectivas ao redor, não por uma relação em linha reta entre dois pontos. Só faz sentido falar de ação quando lidamos com seres humanos, no plural, e isto, por sua vez, só é possível quando há um espaço em que a singularidade possa aparecer efetivando a pluralidade, ${ }^{114} \mathrm{e} \mathrm{o}$ valor atribuído por Arendt a este espaço é inversamente proporcional ao desprezo a ele conferido por Heidegger em sua análise do das Man.

Um dos traços da filosofia política tradicional é precisamente afastar de suas considerações esta pluralidade procurando na ação humana, ou nos seres humanos, o que há de comum, de idêntico, de uno. Marx, em sua rebelião contra a tradição, já havia percebido a inadequação de pensar a política em termos de Homem, como mostra sua crítica às "robinsonadas" dos filósofos políticos do XVIII, que elaboraram suas filosofias sempre sobre o pressuposto de que não há grandes diferenças entre o homem pensado isoladamente e os humanos pensados no plural, de modo que, para eles, as sociedades nada mais são do que a convivência de vários Robinson Cruoé. ${ }^{115}$ Com esta crítica, Marx aponta para o procedimento da filosofia burguesa de universalizar sua própria imagem e fantasiar sua coincidência com a imagem do Homem, procedimento contra o qual o filósofo rebelde desfaz esta pretensa universalidade mostrando que não há o Homem, concebido idealmente e fora da história, mas há tantos seres humanos quantas são as posições oferecidas por um modo de produção da vida. Arendt, por sua vez, concorda com Marx na recusa de um homem universal, concorda também no vínculo entre os seres humanos e suas posições no sistema de produção. No

\footnotetext{
${ }^{113}$ Arendt, The Human Condition, p.7

114 Partindo de preocupações distintas, Bethânia Assy trata desta mesma questão de modo mais extenso e cuidadoso no segundo capítulo de seu Ética, responsabilidade e juízo em Hannah Arendt.

${ }^{115}$ Cf. p. ex. Marx, Grundrisse, p.39-44.
} 
entanto, diante das insuficiências da rebeldia filosófica de Marx, Arendt desvincula o modo de produção e a totalidade do humano procedendo a distinção entre o animal laborans e o homo faber, partes importantes dos seres humanos, mas não sua totalidade. Do ponto de vista arendtiano, portanto, temos certa unidade entre os seres humanos garantida pela vida, idêntica em todos; certa variedade vinculada à artificialidade, ou seja, ao mundo e à abertura que este oferece; e a singularidade, que se expressa no encontro de diferentes, na atualização da pluralidade.

Para incluir de modo sério a pluralidade na arquitetura de seu pensamento, Arendt se apoia em uma estrutura temporal formada por um ponto a partir do qual processos são iniciados e jamais terminados. Este ponto é a manifestação da singularidade, ou, em termos propriamente políticos, é a performance da ação; e os processos equivalem às imprevisíveis e irreversíveis consequências da ação. Enquanto o trabalho e a fabricação estão enraizados na relação com o corpo e com os objetos e têm finalidades determinadas, a ação é pura performance, é relação com o outro, dirige-se a ele, é respondida por ele e transformada por essa relação. É puro acontecimento, um início que se dá em um mundo já existente e no interior do qual reverbera indefinidamente. Assim, a fim de apresentar seu conceito de ação, Arendt recorre a uma temporalidade aberta e, por meio dela, oferece a possibilidade de pensar o indeterminado sem deforma-lo.

Se a ação corresponde à chegada do novo em um mundo já posto, não faz sentido pensa-la em isolamento. Ou seja, a presença de outros é condição para ação, tanto no sentido de que ela não é possível sem a pluralidade, quanto no sentido de que a ação é necessariamente condicionada pela presença dos outros. As consequências teóricas mais evidentes desta formulação estão na recusa de considerar a ação, por um lado, como pura expressão da vontade, como atividade soberana e, por outro, como puro resultado de alguma determinação. A ação é, de fato, ancorada ontologicamente na impenetrável escuridão do coração humano; entretanto, ela não é a expressão pura dos eventuais "conteúdos" da alma de um indivíduo, mas a efetivação de sua singularidade, o que só tem sentido no interior da diferença formada pela presença de outros. Uma vez que a performance da ação acontece, ela reverbera nas várias singularidades que compõem o espaço-entre desencadeando reações, ou seja, novas ações, novos inícios ancorados nas singularidades participantes da rede de relações em que a ação se insere.

Neste sentido, a ação não é soberana e nem mesmo individual stricto sensu, pois, 
embora ela se apoie na vontade do agente e na obscura identidade da alma, ela só existe no interior de uma rede, só ganha sentido na pluralidade constituída por quem está ao redor; ela é, em suma, constituída também pela situação em que ocorre. É inegável que grandes agentes políticos, como Rosa Luxemburgo, Zumbi dos Palmares ou César Borja, dão mostras de grande coragem, sagacidade, capacidade persuasiva e outras qualidades individuais. No entanto, também não se pode negar que o valor individual de cada um deles só se fez possível e só ganhou sentido porque suas ações se deram em determinado tempo e lugar, no interior de uma determinada rede de relações formada por múltiplas singularidades, da qual faziam parte tanto os adversários contra os quais se colocaram quanto os apoiadores de quem ganharam suporte e com quem agiram em concerto. ${ }^{116}$ Fosse outra a rede de relações, a ação e seus efeitos seriam outros, bem como o agente e o sentido de sua ação.

Uma vez que a performance da ação se deu introduzindo o novo no interior de uma rede de relações existente, inicia-se um processo a partir daquela ação. Este processo forma as consequências dos atos e das palavras do agente, que reverberam no espaço-entre afetando singularidades de modo inteiramente imprevisível. Como a ação não se dá no vazio, mas em concerto com e contra pessoas, todo agente se esforça para prever a recepção de sua ação pelos demais, para antecipar as reações que desencadeará. Embora praticamente inevitável, este esforço é, no entanto, essencialmente precário, uma vez que ele consiste em prever o impacto de suas ações na obscuridade da alma, na pluralidade. ${ }^{117}$

Esta maneira de conceber a ação leva Arendt a atribuir-lhe duas características fundamentais; a irreversibilidade e a imprevisibilidade. A irreversibilidade da ação se deve à impossibilidade de desfazer a revelação já realizada, de revogar o novo que já chegou, de anular o impacto exercido por sua chegada sobre o que antes estava aí. Sua imprevisibilidade se assenta na pluralidade, pois é ela que impede de saber a priori quais serão as reações que, vinculadas a ela, iniciarão novos processos igualmente imprevisíveis e irreversíveis. Agir é, portanto, atividade arriscada e incerta, repleta de perigos, de modo que apenas sobre uma temporalidade aberta seja possível pensá-la adequadamente.

A tradição, evidentemente, percebeu os riscos da irreversibilidade e da imprevisibilidade da ação, por sua vez derivados da pluralidade, e, diante deles, fez surgir

${ }^{116}$ Este suporte formado pelo apoio mútuo de muitas pessoas é chamado por Arendt de poder, por oposição a violência, vigor e força. Há uma caracterização destes conceitos no $\S 28$ de A condição humana, mas o texto clássico, em que as distinções são realizadas e discutidas mais extensamente, é o ensaio "Sobre a violência", publicado isoladamente e na coletânea Crises da república. 
com frequência a tentação de substituir a ação pela fabricação, muito mais controlada tanto em seu exercício quanto no produto que dela resulta. Platão foi o primeiro a ceder a esta tentação ao ordenar tanto a alma do ser humano quanto a estrutura da cidade - que nada mais é do que o humano escrito em letras maiúsculas — sob o jugo da ideia de bem, oferecendo maiores possibilidades de estabelecer uma organização sólida e permanente para as relações humanas. Seu Estado ideal não resulta de ações, mas da fabricação de um Estado que seja sólido e permanente como um objeto. Em termos temporais, isto quer dizer que Platão, a fim de oferecer um remédio para as angústias da temporalidade aberta da ação, estabeleceu um critério eterno, imutável, situado fora do tempo a partir do qual se pode medir e julgar as ações, do que resultou o esforço de pensar um Estado situado igualmente fora do tempo. "Este esforço de substituir o agir pelo fabricar é manifesto no conjunto de argumentos contra a 'democracia', que, quanto mais consistentes e melhor elaborados (reasoned) forem, melhor se converterão em argumentos contra o essencial da política."118

$\mathrm{Na}$ ponta oposta da tradição, os existencialistas franceses se encontram ainda em sérias dificuldades a este respeito. Partidários da rebelião contra a tradição, os existencialistas elaboram vigoroso elogio da ação e, de modo consequente, não cedem à tentação de substituila pela fabricação. No entanto, por desenvolverem uma concepção de liberdade que a identifica à soberania, desembocam em contradições insolúveis, pois o humano é tomado como um ser "capaz de iniciar algo novo, mas incapaz de controlar ou mesmo prever suas consequências, o que parece quase nos forçar à conclusão de que a existência humana é absurda. Diante da realidade humana e de sua evidência fenomênica, é de fato tão espúrio negar a liberdade humana de agir porque o agente nunca permanece como o senhor de seus atos, quanto sustentar que a soberania humana é possível devido ao fato incontestável da liberdade humana."119

Mantendo-se firme na ruptura, Arendt se recusa a escapar tanto para fora do tempo quanto para dentro do desespero, pois, por um lado, critica explicitamente a tradição por esta ter sempre pensado a ação em termos de fabricação e, por outro - e aqui a noção de amor mundi mostra uma de suas facetas - porque Arendt não rejeita a contingência que limita a soberania da vontade, mas a acolhe como um dos traços essenciais do mundo e da condição humana. Este acolhimento é antitradicional também porque afasta a ação e a liberdade do

\footnotetext{
117 Cf. Villa, The Fate of the Political, pp.82-9

118 Arendt, The Human Condition, p.220

119 Arendt, The Human Condition, p.235. Cf. tb. Taminiaux, La Fille de la Thrace et le penseur professionnel, pp.74-6
} 
âmbito do possível, no interior do qual Aristóteles e toda a tradição pensam a ação, aproximando-as do âmbito do contingente, formado por séries causais independentes cujos fins não estão relacionados. Cada ação desencadeia no mundo processos irreversíveis cujos destinos são imprevisíveis e Arendt, longe de tentar combater a contingência formada por todos estes processos, apresenta, também em termos temporais, os dois únicos remédios propriamente políticos para as angústias da contingência. Contra a irreversibilidade da ação, a única saída é o perdão, ou seja, uma ação que, iniciando algo novo, pretende colocar fim a um processo iniciado por uma ação anterior e liberar o agente de suas consequências. A promessa, por sua vez, é uma ação que pretende diminuir a imprevisibilidade da ação afirmando existir, tanto quanto possível, certas ilhas de certeza em um futuro inteiramente aberto. Ao prometer, o agente procura oferecer certa estabilidade às relações afirmando que sua alma, essencialmente insondável, permanecerá a mesma no futuro.

Esta indefinição essencial que marca a ação não resulta na impossibilidade de pensala. De fato, como vimos acima, o conhecimento fracassa quando toma a alma como objeto, de modo que a singularidade lhe escapa inteiramente. Além disto, a imprevisibilidade dos resultados da ação e a impossibilidade reverte-la tornam a situação ainda mais difícil para o conhecimento, que se mostra tão útil quando lida com o animal laborans ou mesmo com o homo faber. Se não há nenhuma possibilidade de conhecer a priori nada relacionado à ação, isto não retira a força de um olhar a posteriori para a ação já realizada e para seus desdobramentos. Ou seja, o fracasso do conhecimento não impede a elaboração de uma compreensão do que se passou, tarefa a ser realizada pelos historiadores (storyteller) e capaz de oferecer algum sentido a toda abertura representada pela ação. Este tema remete à influência de Walter Benjamin sobre o pensamento de Arendt e tem longos desdobramentos na crítica, ${ }^{120}$ mas, em nosso contexto, importa notar fundamentalmente a inversão de perspectiva do a priori para o a posteriori a fim de abordar o indeterminado do humano sem deforma-lo e, sobretudo, sem repetir o esforço totalizante de eliminar o indeterminado.

${ }^{120}$ O tema é tratado por Arendt em seu ensaio sobre o conceito de história ("The Concept of History: Ancient and Modern" in. Between Past and Future) e no ensaio dedicado a Benjamin presente em Homens em tempos sombrios. Para a importância metodológica atribuida por Arendt à atividade de contar histórias, Cf. Benhabib, The Reluctant Modernism of Hannah Arendt, pp.92-5; Duarte, O pensamento à sombra da ruptura, pp.141-54; "Walter Benjamin" in Heuer et alii. Arendt Handbuch: Leben, Werk, Wirkung, pp.254-5. Cf. tb. Matos, "Storyteller e o flâneur" in: Bignotto / Moraes, E.J, Hannah Arendt: diálogos, reflexões, memórias, pp.90-6. 


\section{Conclusão}

\section{Horror econômico}

No início de nosso trajeto, vimos que a primeira grande análise do comunismo realizada depois do fim da Guerra Fria era bastante crítica ao regime soviético, mas não terminava em tom de celebração pela vitória da ordem ocidental. Contrariamente à ruidosa festa realizada para o suposto fim da história, François Furet se mostra satisfeito com o fim do comunismo, mas profundamente resignado com a única alternativa que, em sua visão, se coloca diante do mundo. Sua exasperação diante do "escândalo do futuro fechado" talvez se dê porque Furet, que ao longo de sua vida abandonou o socialismo em direção à única alternativa que lhe parecia viável, o liberalismo, parece aceitar tacitamente certos postulados da teoria do fim da história então triunfante. Talvez no fundo ele aquiesça, de modo mais ou menos consciente, à ideia segundo a qual a forma política final já tinha sido fabricada e acabava de provar historicamente sua superioridade vencendo a forma rival. $\mathrm{O}$ ocidente vencedor, como se sabe, se apressou para "exportar" ideológica e belicamente sua forma política para os cantos "atrasados" do mundo que ainda não atingiram esta forma última, e, embora não seja possível concluir aqui a posição de Furet diante desta "iluminação" do mundo, talvez seja possível considerar que ele consentiria com esta marcha rumo ao desenvolvimento máximo dos seres humanos. Isto não significa afirmar que Furet concordaria com a política externa estadounidense ao longo dos anos 1990 e posterior ao 11 de setembro, mas que, no fundo, talvez a visse como expressão do inexorável e bem-vindo avanço definitivo da civilização, malgrado seus problemas.

Mas, se nos acercarmos do pensamento elaborado nesta década de 1990, notaremos que esta dificuldade de enxergar alternativas ao final da Guerra Fria não é exclusividade de autores alinhados ao liberalismo, como Furet. Embora muitos tenham recusado a ideia do fim da história e do futuro fechado, as alternativas não eram visíveis nem mesmo para quem se lançou à crítica do estado de coisas da época. O manifesto publicado por Viviane Forrester um ano depois do livro de Furet é um exemplo disto, uma vez que nele a autora recusa, por um lado, a celebração da situação atual e, por outro, a resignação diante da aparente falta de alternativas e do encerramento do futuro. Para fazer face aos desafios postos pela queda do 
muro, Forrester assume uma atitude completamente diferente e afirma que "ainda que possa conduzir a certo desespero, correr o risco da exatidão, da constatação é (...) o único gesto que, lúcido quanto ao presente, preserva o futuro." ${ }^{1}$. Este gesto lúcido de Forrester, fundado na esperança de que outro mundo é possível, resultou em $O$ horror econômico, manifesto anticapitalista que conheceu enorme sucesso ao redor do mundo e está entre as referências dos movimentos antiglobalização surgidos em meados dos anos 1990.

Assim como o liberal Furet, para quem a década de 1990 representa uma ruptura com o antigo, e como o marxista Eric Hobsbawn, para quem o século XX chegou ao fim em 1991, Forrester também considera estar diante do surgimento de um mundo novo, que, para ela, nasce sob signo da cibernética e de tecnologias revolucionárias. Para que a constatação exata do presente seja possível, afirma Forrester fazendo referência a Poe, devemos nos livrar da "síndrome da Carta roubada", responsável por fazer aquilo que é evidente passar completamente desapercebido pelos olhos de quem procura; ao se livrar desta síndrome, o olhar de Forrester recai sobre atividade do trabalho.

Seu libelo se abre com a afirmação de que vivemos todos sob um "engodo magistral", que consiste em conceber o trabalho como emprego e, ato contínuo, dividir a população entre quem tem e quem não tem empregos. Evidentemente, a transformação do trabalho em emprego não é por si só um engodo e tampouco é novidade dos anos 1990. O ponto para Forrester está no arranjo entre, por um lado, a progressiva desaparição do trabalho no mundo regido pela tecnologia, pela cibernética e pela automação, e, por outro, a centralidade do tema nas discussões públicas. Embora não seja segredo para ninguém que o capital precisa cada vez menos do trabalho para se valorizar, todos se comportam como se o capitalismo ainda fosse capaz de oferecer trabalho a todos os desempregados. Pressionados pela penúria efetiva ou potencial, trabalhadores empregados ou desempregados demandam de seus governantes medidas econômicas favoráveis à criação de empregos; os governantes, por sua vez, repetem diuturnamente seu compromisso com o emprego; o capital, por fim, fecha postos de trabalho afirmando não ser capaz de dar conta das regulações impostas pelo Estado e pelos trabalhadores. Todos fingindo não perceber o óbvio: não há e não haverá emprego para todos, mesmo que os trabalhadores recebam ainda menos, mesmo que os governantes realizem suas promessas.

Os resultados deste artifício não são apenas ludibriantes, mas também cruéis, uma vez que ele está na base da terrível situação em que um número cada vez maior de seres humanos

\footnotetext{
${ }^{1}$ Forrester, L'Horreur économique, p.173
} 
se encontra neste mundo que Forrester via se abrir e que nós vemos já estabelecido. A crueldade do engodo está encapsulada no título do livro, capaz de denunciar, ao mesmo tempo, tanto a impostura de certo discurso econômico quanto seus hediondos resultados.

A locução "horror econômico" é retirada de "Soir historique", um dos poemas em prosa que compõem (Les) Illuminations de Rimbaud. ${ }^{2}$ De acordo com Pierre Brunel, cuja interpretação nos orienta aqui, ${ }^{3}$ o "soir" do título é denso e repleto de ambiguidades históricas estreitamente vinculadas às agitações políticas vividas pela França em meados do século XIX. Dentre as referências mais importantes, está a trajetória de certo jornal chamado "Le soir", fundado em 1867 e que inicialmente oferecia uma oposição moderada ao Império até o 04 de setembro de 1870, quando a Terceira República foi proclamada e o jornal, depois de se alinhar ao governo da Defesa Nacional e sustentar a política de Thiers, passou a apoiar o estabelecimento de uma República conservadora antes de abandonar o que restava da república e ser comprado pelo partido orleanista. "A este fim de tarde (soir) morno e traidor, Rimbaud só pode opor interiormente a 'Grande Tarde', ou seja, aquela que, segundo os revolucionários extremistas, deve um dia destruir o estado de coisas atual."4

Contra este fim de tarde e pela Grande tarde, o poeta opõe duas visões da natureza; a visão do "turista ingênuo", descrita poeticamente como mítica, lendária, irreal, e a visão do "ser sério", que é histórica, objetiva, real. O turista ingênuo encarna o tipo burguês e a poesia romântica, com sua tendência a escapar do real por meio de fantasias cuja doçura é proporcional ao amargor do real de que foge. É por isto que

\footnotetext{
Em qualquer noite (...) em que se encontre o turista ingênuo, afastado de nossos horrores econômicos, a mão de um artista anima o clavecino dos prados; joga-se baralho no fundo do lago, espelho evocador de rainhas e das pequeninas: no crepúsculo, estão as santas, os véus, e as cordas da harmonia, e os cromatismos lendários.
}

O turista ingênuo, no entanto, não é tão ingênuo assim. Ou melhor, ele é ingênuo quanto a si e quanto ao valor que atribui a sua visão das coisas, mas não é nada ingênuo quanto ao mundo de que se afasta. Afastando-se do mundo onde o horror econômico se efetiva, os burgueses realizam uma "augusta retirada" e fazem uma ópera fabulosa que tem

\footnotetext{
${ }^{2}$ Existem questões relativas à presença do artigo definido no título original do livro. Em português, o título foi vertido ora por lluminações, ora por lluminuras e o poema em questão, ora por "Tarde histórica", ora por "Noite histórica". Servimo-nos aqui da tradução de Lêdo Ivo, a de mais fácil acesso. Cf. Rimbaud, A - Uma temporada no inferno \& Iluminações. Tradução, introdução e notas: Lêdo Ivo. Rio de Janeiro: Francisco Alves, 1981 (3ำ edição).

${ }^{3}$ Cf. BRUNEL, Éclats de la violence: pour une lecture comparatiste des 'Illuminations' d'Arthur Rimbaud, pp.661-74.
} 
como atores o mundo e a história domados e reduzidos a uma calma monotonia. A ilusão burguesa está em considerar que tudo aquilo que é tocado pelo capital se transforma em algo novo e brilhante, quando na verdade se transforma apenas na projeção de si mesmo. Como ele no fundo sabe que tudo isto não se passa de ilusão, de encobrimento da realidade, o turista ingênuo "estremece à passagem dos caçadores e das hordas. A comédia sobre os teatros de feira da relva. E o embaraço dos pobres e dos fracos nesses planos estúpidos!"

Nas mãos de Forrester, a crítica à irrealidade da burguesia se vincula à euforia do fim da história e, em especial, ao papel desempenhado pela prodigiosa tecnologia, que já nos anos 1990 causava vertigens na ensaísta por permitir a ampliação avassaladora da extensão do domínio capitalista e da intensidade do controle por ele exercido. A ideia de que a ordem ocidental era a forma política superior e definitiva abriu caminho para que a lógica do capital, fiel escudeira desta forma política, se impusesse à metade do mundo sobre a qual tinha pouca influência até então. Neste mesmo movimento, o acentuado desenvolvimento tecnológico tornou possível a implantação de formas de controles cada vez mais eficientes. No mundo que se abre para Forrester, uma pequena elite dirigente, fisicamente localizada em alguns poucos escritórios modernos espalhados pelo planeta, conectados entre graças à tecnologia, que permite ainda grande fluxo de dados cada vez mais precisos, controla soberanamente parcelas cada vez mais amplas do mundo com base em harmoniosos planos econômicos. Por força da lógica, quanto maior e mais preciso o controle permitido pelas tecnologias, menor o número de controladores necessários; quanto menor o número de controladores, mais distantes eles se encontram do objeto que controlam, do que resulta que tudo se passe, de fato, como quem joga cartas no fundo de um lago, ao som de um clavecino e afastado dos horrores econômicos do mundo concreto.

É certo que a crítica de Forrester ao capitalismo da década de 1990 envelheceu em certos pontos, mas ela é importante aqui por encarnar a recusa do "escândalo do futuro fechado", por explicitar o "engodo magistral" que está diante dos olhos de todos, mas sobretudo pela força do título do livro. Isto porque, ao vincular horror e economia, Forrester embaralha habilmente a distinção estanque e firmemente estabelecida entre totalitarismo e economia de mercado, sem, no entanto, fazer qualquer concessão ao regime da URSS. A partir do final da Segunda Guerra estabeleceu-se como "evidência" a ideia de que todas as formas de ação coletivas, de ações que não são fundadas no interesse individual colocam-nos invariavelmente no caminho da servidão e do totalitarismo. Esta "evidência" é o lastro da

\footnotetext{
${ }^{4}$ Brunel, Éclats de la violence, p.666
} 
interpretação segundo a qual a ruína da URSS fazia ruir também a última grande ameaça à liberdade; é também ela a responsável pela dificuldade de Furet em imaginar um futuro e, inversamente, pelo consentimento de Žižek ao ser qualificado como totalitário. Contra esta evidência, Forrester denuncia o horror causado precisamente por aquilo que se supunha ser o antídoto para o horror; a lógica de mercado.

Como indicamos acima, os avanços tecnológicos permitiram a ampliação extensiva e intensiva do domínio e do controle do capital, favorecendo a separação entre a elite e o mundo por ela controlado cada vez mais remotamente. Mas é necessário notarmos ainda que a tecnologia também permite que o capital prescinda cada vez mais do trabalho para se valorizar, ou seja, que ele expulse trabalhadores do mundo do trabalho. Evidentemente, os trabalhadores não vivenciam esta situação como a realização do sonho imemorial de se livrar da faina, mas, ao contrário, como constante risco de cair na penúria decorrente do desemprego. Este risco é convertido em ameaça pela constante "incitação" à procura e à manutenção do emprego com que os controladores mantêm em movimento os trabalhadores do mundo inteiro dando a este "estímulo" a forma concreta de cortes nos gastos sociais, de mudanças no regime previdenciário, de discurso contra os direitos trabalhistas, de flexibilização do horário e local de trabalho etc.

É elucidativo notar aqui que, na França, de onde escreve Forrester, não se fala exatamente em desempregados, mas em démandeurs d'émploi, em solicitadores de emprego. Esta maneira de nomear traz o substantivo démandeur — "solicitador", "pedinte" oferecendo duas vantagens para nossa análise. A primeira é que ele torna particularmente evidente a substancialização deste extrato social, ou seja, a presença de uma definição operando quando tratamos dele. A segunda vantagem está em que esta substancialização se dá pelo movimento realizado em direção ao trabalho (e não pela falta de emprego, como é o caso do nosso termo "desempregado"). Assim, os solicitadores de emprego formam um extrato social cuja definição é composta por uma situação e por um movimento específico. A situação consiste em estar fora do mundo do trabalho e é imposta pelo capitalismo contemporâneo, que cada vez mais prescinde de trabalho; o movimento específico se dá previsivelmente na direção do mundo do trabalho e é imposto pela vida, que está ameaçada pela penúria vinculada à situação.

Ora, se considerarmos que o mundo do trabalho em sociedades capitalistas aceita apenas os indivíduos que têm força de trabalho para trocar por um salário, perceberemos que a linha que circula os solicitadores de emprego, que estabelece a divisão entre o dentro e o 
fora do mundo do trabalho é a mesma que define o humano por uma "tendência ou propensão existente na natureza humana (...): a propensão a intercambiar, permutar ou trocar uma coisa pela outra." 5 A propensão natural à troca oferece a Smith, como se sabe, um fundamento sobre o qual se faz possível elaborar sua teoria da divisão do trabalho, do funcionamento do mercado e mesmo uma filosofia política a partir de sua obra. Esta mesma propensão oferece ao capitalismo contemporâneo o fundamento sobre o qual é possível dividir quem está dentro e quem está fora do mundo do trabalho, quem está remediado, mas ameaçado, e quem está lançado para fora do conjunto dos humanos.

Evidentemente, esta definição do humano e a exploração econômica a ela vinculada não são novidades do mundo que se abre diante de Forrester. Mas há uma assustadora novidade no arranjo entre a centralidade conferida a esta maneira de definir o ser humano, o desaparecimento gradual do trabalho e do emprego, e as formas contemporâneas de controle exercido remotamente. A situação é tenebrosa porque toma o humano por sua capacidade de troca e, ao mesmo tempo, retira a utilidade daquilo que a maioria dos humanos tem para trocar - a força de trabalho. E a esta produção de humanos inúteis, associa-se um controle cada vez mais estrito e soberano sobre a atividade do trabalho.

Estamos em plena democracia. No entanto, aquilo que ameaça está prestes a ser dito e já é quase murmurado: "supérfluo" (...) Nós não ignoramos mais, não podemos mais fingir ignorar que tudo é possível ao horror, que não existem limites às decisões humanas. Da exploração à exclusão, da exclusão à eliminação, talvez a explorações inéditas e desastrosas; este roteiro é impensável? ${ }^{6}$

O arranjo entre uma definição do que é o humano, a fabricação de seres humanos supérfluos e a controlada submissão de populações vastíssimas a uma lógica impessoal e sem aparência evidencia grandes semelhanças entre o mundo que se abre a Forrester e os campos de concentração descritos por Hannah Arendt em Origens do totalitarismo. Estas similaridades merecem atenção e, ao olhar com cuidado para elas, rompe-se a euforia e o otimismo com o suposto fim da história, desfaz-se o olhar benevolente sobre a liberdade estabelecida pela lógica do mercado e pela ideologia a ela associada, termina a inocência de considerar que o risco totalitário era exclusividade do marxismo e tinha sido afastado com o fim da URSS; ou seja, quando enxergamos o horror econômico, ilusões profundas que sustentaram a Guerra Fria são imediatamente liquidadas.

Embora historicamente inserida na Guerra Fria, Arendt elaborou um pensamento

\footnotetext{
${ }^{5}$ Smith, A riqueza das nações, livro I, cap.2
} 
preocupado com a dissolução de certas ilusões que sustentavam a oposição "totalitarismo vs. democracia" tal qual concebida por certa ideologia então vigente e até hoje ainda bastante atuante. Como vimos na "Introdução", certa imagem de Hannah Arendt foi forjada em um primeiro momento a partir de um questionável recorte responsável por reduzir sua obra à terceira parte de Origens do totalitarismo. Apesar da força deste trecho arbitrariamente selecionado, o pensamento de Arendt ganha potência maior quando o totalitarismo deixa de ser concebido como uma forma de governo superada e se converte na questão do totalitarismo, que anima toda a sua obra posterior. Os primeiros passos deste desdobramento a partir de Origens do totalitarismo resultaram, como vimos ao longo desta tese, em $A$ condição humana, livro onde encontramos uma crítica fina e muito bem articulada ao procedimento de definir o humano.

Muito da ideologia da ordem ocidental encontrava as causas do totalitarismo em todas as formas de ação coletiva, em que o indivíduo é suprimido por demandas feitas em nome de uma coletividade dita abstrata. Contra o coletivismo, impunha-se então o elogio e o fomento ao interesse individual, à "propensão natural à troca", que, em sociedades modernas, se concretiza principalmente por meio da troca de força de trabalho por um salário, ou seja, por meio do emprego. Em meados dos anos 1950, quando Arendt escrevia A condição humana, já se via com clareza que a automação e a tecnologia tenderiam a diminuir a necessidade do trabalho, mas isto não impediu o predomínio da ideia de que o combate ao totalitarismo se faria pela ampliação da atividade do trabalho e do interesse individual para todas as esferas da existência. Esta ilusão é atacada logo no prólogo do livro, onde se lê que até mesmo

$$
\begin{aligned}
& \text { presidentes, reis e primeiros ministros consideram sua ocupação em termos de um } \\
& \text { emprego necessário à vida da sociedade e, dentre os intelectuais, restam apenas } \\
& \text { alguns indivíduos solitários que consideram o que fazem em termos de fabricação e } \\
& \text { não em termos de ganhar a vida. O que temos diante de nós é a perspectiva de uma } \\
& \text { sociedade de trabalhadores sem trabalho, ou seja, sem a única atividade que lhes } \\
& \text { sobrou. É certo que nada poderia ser pior do que isto. }
\end{aligned}
$$

Embora $A$ condição humana não se restrinja à crítica ou à denúncia do presente, a ideologia fundamental da ordem ocidental é frontalmente combatida desde o início. Não há, em Arendt, qualquer vestígio da ideia de que a ampliação do espaço de trocas comerciais e das liberdades trazidas por ele ofereça empecilho sério ao totalitarismo. Talvez até se possa afirmar que a liberdade de concorrência atrapalha o surgimento de ditaduras — afirmação

\footnotetext{
${ }^{6}$ Forrester, L'Horreur économique, pp.21-2

${ }^{7}$ Arendt, The Human Condition, p.5
} 
contra a qual a autora teria muitas ressalvas ${ }^{8}$ - , mas o ponto é que a obra arendtiana não é exatamente um alerta contra ditaduras, e sim uma análise da questão do totalitarismo. Embora os governos totalitários de Hitler e Stalin tenham surgido de ditaduras, um governo ditatorial não é condição necessária para o domínio totalitário. Consequentemente, é perfeitamente possível que o domínio totalitário se desenvolva sem ameaçar sistemas políticos que costumamos chamar de democráticos. O horror econômico é prova desta possibilidade e, mais do que isto, é prova também da possível confluência entre o totalitarismo e estes sistemas democráticos.

Para desdobrar a questão do totalitarismo tornando visíveis elementos totalitários operando fora de governos totalitários, Arendt realizou, como vimos no primeiro capítulo, uma mudança de registro ao passar de Origens do totalitarismo para A condição humana. ${ }^{9} \mathrm{~A}$ partir da pesquisa sobre os elementos totalitários no marxismo, ela notou que um elemento inicialmente percebido em Marx é na verdade comum a toda a tradição de filosofia política, desde Aristóteles. O procedimento de determinar a differentia specifica do humano circunscrevendo-o totalmente em uma essência definida, sobre a qual a filosofia política deve se fundamentar é comum aos pensadores da tradição desde o zoon politikon de Aristóteles, passando pelo animal rationale da filosofia latina, pelo homem como proprietário de Locke, como ser propenso a trocas de Smith, até o animal laborans de Marx. Deve-se a este procedimento a pretensão que a filosofia política traz, explícita ou implicitamente, de conhecer ou entender completamente o ser humano, uma vez que o ato filosófico de definir é sempre um esforço de estabelecer com precisão o que está dentro e o que está fora do ente definido, o que é um e o que é outro, o que é e o que não é. Deste procedimento, decorre a possibilidade de apreender totalmente o ente definido por meio do logos, que, afinal, estabeleceu seus limites. Quando aplicado ao humano, este procedimento se converte em um elemento totalitário da tradição de filosofia política, que por isto se mostra, como vimos, incapaz de abordar adequadamente aquilo que há de indefinível nos seres humanos.

Diante desta constatação, a saída não pode ser outra que o esforço para desmontar a tradição inteira e oferecer um pensar alternativo a ela. Se a marca do totalitarismo na tradição

\footnotetext{
${ }^{8}$ A facilidade deste argumento é posta à prova pela afirmação de que a relação do tipo burguês com a política é a de quem pretende se livrar dos assuntos públicos para se dedicar aos assuntos privados, do que decorre o interesse por parte da burguesia em apoiar um homem forte e abnegado o suficiente para tomar para si o peso dos assuntos públicos. Cf. p. ex. Arendt, The Origins of Totalitarianism, pp.311-5

${ }^{9}$ Cf. supra pp. $35-6$
} 
está em definir o humano e tomar sua essência como fundamento para uma filosofia política, o novo pensar político deve partir do problema da determinação e é precisamente esta a preocupação de saída de A condição humana. Como vimos, Arendt aborda o problema por meio de uma descrição das diferentes temporalidades (e espacialidades) presentes na última definição tradicional do humano, a de Marx. Esta abordagem a leva à dissolução da definição marxista de ser humano como animal laborans em duas atividades de sentidos inteiramente distintos; ali onde Marx define o trabalho, Arendt vê trabalho e fabricação. No entanto, como a fabricação e o trabalho foram extraídos de uma definição, o indefinido ainda não pode ser adequadamente contemplado com esta dissolução, e é por isto que Arendt oferece uma terceira temporalidade, a da ação, estruturada por um ponto a partir do qual se segue uma abertura indefinida, inteiramente aberta e formada por elementos apreensíveis apenas $a$ posteriori.

\section{Alienação do mundo}

Baseada neste quadro das temporalidades apresentadas ao longo de $A$ condição humana, Arendt encerra seu livro com um balanço do mundo que tem diante dos olhos, ou seja, com uma análise da ordem ocidental em meados dos anos 1950. Este balanço se abre com a apresentação de três grandes eventos que, segundo ela, estão no "limiar da era moderna e determinam seu caráter: o descobrimento da América e a subsequente exploração de toda a Terra; a Reforma, que, pela expropriação das posses eclesiásticas e monásticas iniciou um processo duplo de expropriação individual e acúmulo de riqueza social; a invenção do telescópio e o desenvolvimento de uma nova ciência que considera a natureza da Terra do ponto de vista do universo." ${ }^{10}$ Uma vez mais, Arendt realiza um grande recuo no passado para analisar o presente, ${ }^{11}$ o que pressupõe necessariamente a consideração de que existe uma conexão profunda entre estes momentos tão distantes entre si. Esta conexão se funda na

\footnotetext{
${ }^{10}$ Arendt, The Human Condition, p.248

${ }^{11}$ As ocasiões são várias ao longo da obra arendtiana. No decorrer deste trabalho, vimos esta operação no retorno a Platão para explicar a hostilidade da filosofia contra a política, na ideia de tradição, capaz de incluir virtualmente todos os filósofos de Aristóteles a Marx, e no retorno a Descartes, Kant e Schelling para explicar o existencialismo. Em nenhum destes casos, no entanto, a noção de evento parece ter a importância que tem para o último capítulo de $A$ condição humana, que ora apresentamos. A diferença talvez resida na natureza teórica destes retornos a filósofos e na natureza histórica, por assim dizer, dos três eventos que marcaram a modernidade.
} 
noção arendtiana de eventos, ${ }^{12}$ ou seja, de acontecimentos que rompem a linha do tempo introduzindo nela um "antes" e um "depois" qualitativamente distintos. Estruturado sobre a mesma temporalidade da ação, o evento ecoa ao longo do tempo por meio de consequências irreversíveis e compreensíveis apenas a posteriori, e é precisamente este movimento de compreensão que encontramos nesta análise do presente feita a partir do nascimento da modernidade.

Esta valorização dos traços de continuidade separa marcadamente o pensamento arendtiano do de autores para os quais o fim da URSS representa uma grande ruptura. Evidentemente, deve-se tomar cuidado com o erro de anacronismo aqui, mas parece bastante razoável afirmar que, se adotarmos o ponto de vista desta continuidade histórica que se estende do século XVI até meados dos anos 1950 e inclui, por exemplo, a formação dos EUA, a Revolução Francesa e a Revolução Industrial, o fim da URSS dificilmente aparece como uma ruptura especialmente decisiva. Consequentemente, de um ponto de vista arendtiano, parece um tanto suspeita a afirmação de que 1991 marca o fim da história ou mesmo a abertura de um mundo inteiramente inédito ao ocidente, para falarmos como Furet e Forrester. ${ }^{13}$ Esta diferença evidencia que a análise arendtiana do contemporâneo se situa em nível diferente, mais profundo, vinculado à descrição de traços mais permanentes da condição humana apresentados ao longo do livro.

Partindo da pergunta "o que estamos fazendo?", o livro se encerra com a afirmação de que estamos nos alienando do mundo ao nos centrarmos na vida e no trabalho. A alienação do mundo é apresentada por Arendt como a principal marca da modernidade e está presente nos três eventos acima referidos. Notemos de saída que a alienação aqui nada tem a ver com a alienação pensada por Marx, pois não aponta para a distância entre os homens e aquilo que produzem sob o capitalismo, mas indica o significado de certo afastamento dos seres humanos com relação ao mundo, de uma fuga que nos lança para fora da Terra ou para dentro de nós mesmos; trata-se de alienação com relação ao mundo, não ao homem.

\footnotetext{
${ }^{12}$ Cf. supra pp.43-4

${ }^{13}$ Com Hobsbawn há uma convergência, sustentada fundamentalmente no fato de que ele é mais modesto quanto à importância do corte que pretende estabelecer. Os anos de 1914 e 1991 marcam, para ele, apenas o início e o fim de um século, não o fim da história, nem a abertura para um novo ocidente. Arendt, nas primeiras linhas de sua análise do imperialismo, afirma explicitamente que o século XX começou com a primeira guerra (Cf. Arendt, The Origins of Totalitarianism, p.123). Quanto a 1991, a questão se torna difícil e talvez ociosa porque Arendt faleceu em 1975. De todo modo, é possível lembrar que Arendt se referiu várias vezes ao século $X X$ como século das catástrofes, de modo que, se tomarmos este critério como o definidor, o século XX parece não ter terminado.
} 
Cada um dos três eventos contribui para a alienação à sua maneira. As grandes navegações ampliaram a Terra de modo inédito ao incluir, no mundo conhecido pelos europeus, terras e mares até então existentes apenas na fantasia. Como estas as aventuras excepcionais não foram as únicas, mas apenas as primeiras de muitas outras travessias, os grandes deslocamentos na Terra se normalizaram ao longo dos séculos e perderam paulatinamente seu caráter aventureiro e excepcional. Somada aos avanços da técnica, que permitiram o aumento exponencial da velocidade dos deslocamentos e a redução igualmente drástica do tempo necessário para percorrer longos trajetos, esta normalização alterou profundamente o sentido das grandes viagens pela Terra ao longo da modernidade. Se as primeiras viagens retiraram os navegadores do lugar que os enraizava apresentando-lhes uma alteridade quase total, elas são hoje contadas como rotineiras no movimento diário de pessoas, mercadorias e informações entre continentes. A relação com a Terra paulatinamente dá lugar a uma relação com o planeta, com um todo conhecido, esquadrinhável e que começa a caber em uma representação mais racional, como prova o avanço da cartografia.

A alienação do mundo vinculada ao segundo evento, a Reforma protestante, é distinta e já foi em grande medida antecipada pela "ascese intramundana" formulada por Weber. Entretanto, Arendt opera um deslocamento ao retirar a ascese intramundana da moralidade protestante e colocá-la na expropriação do campesinato promovida pelo início do capitalismo. ${ }^{14}$ Deixando evidente que, para a alienação do mundo, a expropriação foi um evento mais significativo do que a ética então nascente, Arendt a coloca no centro de sua análise da Reforma. Entretanto, e em sintonia com análises da antiguidade já apresentadas, ${ }^{15}$ a propriedade não aparece aqui como elemento de riqueza de uma pessoa ou família, mas como lar, como home ou como Heimat, como elemento que enraíza alguém no mundo porque indica com precisão o lugar que nele ocupamos. A expropriação do campesinato que deu origem ao capitalismo contribui para a alienação do mundo precisamente porque, com ela, este local único e quase sagrado foi lançado em um movimento circular e devorador ao ser convertida em riqueza e, mais tarde, em capital, ou seja, em riqueza que circula incessantemente. Um dos resultados ao longo do tempo foi o desenraizamento de um grande contingente de pessoas, antes assentadas em um local determinado e profundamente significativo, e agora empilhadas nas grandes cidades que mudam ao sabor da economia. Junto a este desenraizamento físico, sobreveio também a exposição nua às exigências da vida

${ }^{14}$ Cf. Arendt, The Human Condition, pp.251-2

${ }^{15}$ Cf. Arendt, The Human Condition, §8 
e a consequente restrição dos expropriados à mera manutenção da vida, à mera atividade do trabalho. Assim, Arendt acompanha Weber na afirmação de que o trabalho se dá em detrimento do mundo, mas discorda dele quanto à direção desta alienação com relação ao mundo. Como vimos, Arendt concebe o trabalho como a atividade resultante das preocupações com a manutenção da vida e esta, por sua vez, se funda no corpo. Consequentemente, o trabalho não lança os seres humanos a alguma ascese transcendente, mas em direção ao seu próprio corpo, a si mesmo, ao self. Enquanto seres ocupados com a manutenção da própria vida, os humanos se preocupam prioritariamente consigo mesmos, de modo que sua relação com o outro é marcada pela competição e sua relação com o mundo, pela utilidade.

A terceira forma de alienação do mundo, vinculada à invenção do telescópio e à filosofia cartesiana, é considerada mais importante do que as duas primeiras. ${ }^{16}$ Isto porque, no entender de Arendt, a principal consequência da descoberta de Galilei e seu telescópio foi a perda da confiança nos dados dos sentidos, responsáveis por nos ajustar ao mundo circundante. Ao derrubar a visão tradicional do cosmos, ou seja, ao conduzir os seres humanos do mundo fechado ao universo infinito, ${ }^{17}$ Galilei desenraizou-os de seu lugar e, mais do que isto, mostrou que as verdades mais etéreas oferecidas pelos sentidos eram puro engano. Além disto, o fato de esta enorme proeza ter sido possibilitada por um artefato humano, o telescópio, marcou a modernidade com a crença de que a verdade não se oferece aos seres humanos, mas deve ser arrancada da natureza pelo engenho.

Não é por outra razão que, no entender de Arendt, toda a "filosofia moderna começa com o de omnibus dubitandum est de Descartes (...). Na filosofia e no pensamento modernos, a dúvida ocupa a mesma posição central que foi ocupada ao longo de todos os séculos anteriores pelo thaumazein grego, o espanto diante de tudo o que é como é."18 Metodicamente desenvolvida, a dúvida cartesiana incide sobre a própria realidade do mundo e a saída encontrada por Descartes foi, no entender de Arendt, a substituição do conceito tradicional de verdade por um "zelo novo e sem precedentes pela veracidade (truthfulness /

\footnotetext{
${ }^{16}$ Arendt, The Human Condition, p.264

${ }^{17}$ Arendt se apoia aqui explicitamente no "brilhante e recente" trabalho de Alexandre Koyré, bem como no de autores aos quais o próprio Koyré se refere (Whitehead, E. A. Burrt, J. H. Randal e O. Lovejoy), especialmente Whitehead (Cf. Arendt, The Human Condition, §36). Arendt e Koyré se conheceram e trocaram cartas formando uma correspondência que consta dos Arendt Papers, mas está escrita em uma letra cursiva de difícil decifração e, lamentavelmente, ainda não foi lida pelos estudiosos.

${ }^{18}$ Arendt, The Human Condition, p.273
} 
Wahrhaftigkeit)"19, ou seja, pelos processos que se passam no espírito e contêm um tipo de certeza que lhes é próprio e distinto da verdade desvelada ao ao ser humano pelo mundo. Esta certeza não é uma verdade, mas uma veracidade que tem nas matemáticas sua mais perfeita expressão, donde a importância do método, garantidor da veracidade das empreitadas humanas. Diante desta solução, é natural que as ciências tenham sido elevadas à condição de patronas do ser humano moderno, e, se considerarmos a necessidade da ciência em ultrapassar os sentidos (senses) e o senso comum (sensus communis), ${ }^{20}$ notaremos que esta primazia sacramenta a desconfiança moderna contra as aparências e as inconstâncias do mundo, no interior das quais acontece a política.

Apesar de sumária, esta apresentação da análise arendtiana dos eventos que moldaram o caráter da modernidade nos permite perceber um sentido geral da modernidade que é determinante e responsável pelo estado de coisas que a autora tem diante dos olhos na década de 1950. O ser humano moderno é fundamentalmente marcado pela alienação do mundo, ou seja, pelo vínculo tênue com o local em que se encontra, pela preocupação quase exclusiva consigo mesmo e pela desconfiança com o mundo tal qual oferecido pelos sentidos. Destas três características decorrem certa indiferença com relação ao lugar específico em que se encontra, uma falta de preocupação com o mundo ao redor e grande confiança naquilo que é produzido humanamente.

A ideia de alienação do mundo como principal característica da modernidade prepara a crítica arendtiana do presente, que se condensa na afirmação da vida como bem supremo e da vitória do animal laborans. A vida, lembremos, é concebida por Arendt como o elemento biológico, o aspecto animal que sustenta nossa existência. Somos vivos na medida em que temos um corpo e, consequentemente, em que estamos submetidos às determinações biológicas, do que decorre a necessidade de exercer uma atividade estruturada sobre sua temporalidade e capaz de responder a estas exigências garantindo a manutenção da vida; esta atividade, vimos, é o trabalho. Assim, vida e trabalho ganham sentido em um espaço muito peculiar, o corpo, que nos separa do ambiente circundante afirmando uma individualidade, sem, no entanto, ser capaz de singularizar alguém. Se é verdade que cada indivíduo se ocupa de seu próprio corpo, é igualmente verdade que as necessidades vitais dos vários corpos não são qualitativamente distintas entre os vários seres humanos, ou seja, embora o corpo separe um "eu" de um "outro", todos os corpos se equivalem no que se refere a suas necessidades

\footnotetext{
${ }^{19}$ Arendt, The Human Condition, p.278

${ }^{20}$ Cf. supra pp.125-6.
} 
básicas e no interesse que delas decorre.

Assim, enquanto trabalhadores, os seres humanos se encerram em si mesmos a fim de atender às exigências impostas pela condição humana da vida e, consequentemente, mantém vínculos muito específicos com aquilo que aparece como outro. Do ponto de vista estrito de quem está trabalhando para manter a vida, ou seja, do ponto de vista do animal laborans, o mundo é concebido como um grande depósito de produtos para o consumo, e os demais indivíduos são tomados prioritariamente como concorrentes a estes produtos. É verdade que laços de cooperação entre alguns indivíduos são possíveis, mas são restritos à possibilidade de um maior acesso aos produtos, ou seja, só ganham sentido quando vão ao encontro da lógica do interesse.

Nota-se com isto que, da concepção arendtiana da vida como o elemento biológico incrustrado na condição humana, decorre a consideração de que a atividade do trabalho e a lógica do interesse a ela associada estão igualmente inseridas na condição humana. Ignora-las ou deixa-las de lado equivale a não considerar um traço importante daquilo que constitui o ser humano. Esta admissão, no entanto, não nos conduz à afirmação oposta, segundo a qual a vida, o trabalho e o interesse constituem ou deveriam constituir a totalidade do humano. A formulação de Arendt evita estas duas posturas opostas porque nela a vida é um, e apenas um dos vários condicionamentos aos quais os seres humanos estão submetidos. A vida é uma condição básica, fundamental, e não pode ser negligenciada, mas ela não constitui a totalidade do humano, ou sequer da vita activa, composta ainda por atividades correspondentes à mundanidade e à pluralidade, e à qual se soma ainda a vita contemplativa. Vê-se com isto que Arendt caminha na direção oposta à da filosofia moderna, que reforçou o procedimento tradicional de operar por definições dos seres humanos e, mais especificamente, colocou a vida no fundamento da filosofia política por meio de definições do homem como o lobo do homem, como proprietário, como ser propenso a trocas, como animal laborans; é precisamente contra o esforço de reduzir o humano ao vital que Arendt localiza com precisão o lugar da vida, da mundanidade e da pluralidade.

\section{Domínio totalitário no neoliberalismo}

Se a principal característica da ordem ocidental dos anos 1950 é a vitória do animal laborans e a consideração da vida como o bem supremo, é porque a maneira tradicional de conceber o ser humano a partir de uma definição e, mais especificamente, de priorizar a vida 
nesta definição ainda está operando com toda força. A ideia de que o risco do totalitarismo se concentra na atuação do Estado e que, contra ele, faz-se necessário expandir ao máximo o espaço de trocas intensificando a atividade do trabalho é consequência direta da moderna alienação do mundo e desta redução dos seres humanos ao animal laborans. Se somarmos a isto o fato de o capitalismo contemporâneo prescindir cada vez mais do trabalho, notamos a gravidade da "perspectiva de uma sociedade de trabalhadores sem trabalho, ou seja, sem a única atividade que lhes sobrou."

Este estado de coisas porta um risco que é melhor compreensível com o recurso à metáfora do deserto, bastante conhecida dos estudiosos da obra de Arendt. Em "Ideologia e terror", capítulo que encerra Origens do totalitarismo, Arendt apresenta o argumento de que o espaço-entre os seres humanos constitui um mundo entre eles. Muito mais do que simples extensão homogênea e neutra, o espaço-entre é dotado de objetos, formas, instituições, que conferem sentido e, sobretudo, estabilidade ao que nele se passa. O conjunto das leis estabelecido e conhecido de todos aparece aqui como um elemento importante, entre outras coisas, por conferir estabilidade e forma ao espaço no interior do qual seres humanos se relacionam. Uma das características da tirania está precisamente em abalar o corpo de leis desfazendo as formas constituintes do espaço-entre e transformando-o em um deserto, em uma zona árida, amorfa e sem referências claras. Imersos neste deserto deixado pela destruição do mundo antes existente, os indivíduos perdem os vínculos mútuos colocados pelo mundo, mas ainda podem se movimentar com alguma liberdade, embora sempre com medo, com suspeita e sabendo que o lugar das dunas que lhes servem de referências muda ao sabor do vento. O totalitarismo também realiza esta destruição de limites e formas, mas é diferente da tirania no que se refere aos movimentos possíveis no deserto. Isto porque o totalitarismo não deixa um espaço vazio para uma hesitante movimentação mais ou menos livre dos indivíduos, mas os recolhe de sua dispersão impondo-lhes um movimento bastante determinado, do que resulta uma massa que caminha rumo à realização da grande Lei que lhe dá sentido.

Um dos equívocos mais comuns cometidos por certa leitura liberal de Hannah Arendt consiste em concluir desta relação entre tirania e totalitarismo que este nada mais é do que uma versão radical daquela. De fato, a tirania destrói o espaço-entre deixando um deserto no lugar em que havia um mundo e este deserto é uma das condições para o domínio totalitário. No entanto, o problema fundamental do deserto está muito menos no governo que o gerou e muito mais na experiência de viver sem mundo e sem espaço-entre, na impossibilidade de 
estabelecer relações humanas significativas com o mundo e com os demais; em uma palavra, o problema fundamental está na solidão. "O que prepara os homens para a dominação totalitária em um mundo não totalitário é o fato de a solidão (loneliness), outrora uma experiência limite sofrida geralmente apenas em certas condições sociais marginais, como a velhice, se tornou uma experiência cotidiana para as crescentes massas de nosso século."21 Ora, longe de ser exclusividade da Alemanha dos anos 1930 e da URSS durante o governo de Stalin, a solidão de indivíduos atomizados é uma realidade presente em todas as sociedades modernas do mundo atual, ou seja, em todas aquelas em que a vitória do animal laborans se consumou, em que e as relações humanas se dão em um deserto onde se encontram indivíduos isolados, autorreferentes, auto-interessados e submetidos à lógica do interesse, no interior da qual os demais indivíduos são prioritariamente concorrentes e o mundo apenas uma fonte de riquezas. A alienação do mundo é característica fundamental da modernidade, de modo que o isolamento seja a experiência fundamental em tiranias modernas, em governos totalitários e também em democracias modernas.

Diante disto, a estratégia de combater o totalitarismo por meio da ampliação do espaço de trocas, no interior do qual os seres humanos trabalham para ganhar a vida, se mostra equivocada, talvez até contraproducente. Se a relação do animal laborans com o mundo e com os demais é de alienação e egoísmo, a atual incitação ao trabalho, à produção e ao consumo que constitui um dos pilares de certa ideologia atualmente dominante corresponde à ampliação do deserto existente entre seres humanos. Se considerarmos ainda que esta incitação ao trabalho não adquire apenas a forma dos cortes sociais e da ameaça do desemprego, mas também aparece na forma da mercantilização de esferas da existência refratárias à lógica de mercado, notaremos que este deserto se amplia em direções inéditas ampliando também os riscos decorrentes da existência de seres humanos atomizados e reduzidos à mera vida. "Se esta prática for comparada à da tirania, parece que encontrou-se uma maneira de colocar o próprio deserto em movimento, de liberar uma tempestade de areia capaz de cobrir todas as partes da terra habitada."22

Um dos principais fantasmas capazes de assustar certo establishment do mundo atual é o surgimento de discursos capazes de unificar estes indivíduos isolados formando uma massa em marcha sob alguma bandeira. Em reação a este medo, de resto justificável, o ideário neoliberal que informa o status quo realiza uma desqualificação das críticas e uma

\footnotetext{
${ }^{21}$ Arendt, The Origins of Totalitarianism, p.478.
}

${ }^{22}$ Arendt, The Origins of Totalitarianism, p.478 
aposta na atomização. A desqualificação se apoia quase invariavelmente sobre o suposto caráter "populista" ou totalitário das críticas, e salta aos olhos o fato de que a desqualificação não se faz a partir de uma análise das tais críticas, mas se apoia exclusivamente no fato de elas se apresentarem como uma alternativa à lógica de mercado, tida como única possível. A famosa TINA! de Margareth Thatcher - There is no alternative! - , repetida enfaticamente diante de todo questionamento junto à lógica de mercado que ganhava hegemonia sob seu governo é expressão clara desta ideia de que a história não tem mais para onde avançar, de que o futuro está fechado e os seres humanos devem se reduzir à temporalidade circular do trabalho a fim de evitar o totalitarismo. O outro lado desta mesma recusa a qualquer alternativa é uma aposta no isolamento do indivíduo que trabalha. Outra afirmação famosa de Thatcher — "Não existe sociedade! Há apenas indivíduos e famílias." — expressa bem este esforço de reduzir os seres humanos a indivíduos que trabalham e, consequentemente, alienam-se do mundo centrando-se exclusivamente na manutenção da própria vida e, no máximo, da dos mais próximos.

Se tomarmos estes desenvolvimentos nos termos apresentados ao longo desta tese, notamos que, ao eleger a lógica da manutenção da vida e do interesse como a única aceitável para o comportamento humano e ampliá-la indefinidamente para todas as esferas da existência, o ideário neoliberal contribui decisivamente para a destruição do espaço-entre, do mundo em que seres humanos são únicos, e amplia o deserto no interior do qual as relações humanas são pouco significativas. A solidão como experiência fundamental da modernidade toma aqui a forma do isolamento competitivo, egoísta e autorreferente e, se o futuro parece fechado, é porque a temporalidade circular do trabalho, no interior da qual a previsibilidade do comportamento deve ser preservada em detrimento de qualquer ruptura, de qualquer novidade, é tomada como a totalidade do ser humano, ou pelo menos seu aspecto mais significativo. Sustenta-se nisto a preocupação primordial com a manutenção de um "ambiente favorável aos negócios", no interior do qual o comportamento de governos e de pessoas é mais previsível permitindo o cálculo adequado do retorno de investimentos; funda-se aqui também a dificuldade de encontrar sentido em atividades não lastreadas no interesse e o consequente esforço de introduzir o interesse onde ele originalmente não tem lugar.

Contra tudo isto, o pensamento de Hannah Arendt nos oferece uma ontologia do ser humano. Não, evidentemente, como mais uma das várias antropologias apresentadas ao longo da história da filosofia, pois esta ontologia surge precisamente da desmontagem da tradição, 
da recusa de oferecer uma definição do humano e do esforço sério de incluir o indeterminado no pensamento a respeito do humano. Em A condição humana, esta ontologia do humano se apoia na descrição dos distintos tempos e espaços que compõem a vita activa (à qual Arendt soma um trabalho análogo relativo à vita contemplativa em $A$ vida do espírito) do que resulta mais um panorama sombrio do século XX. Diferentemente de Origens do totalitarismo, onde encontramos o horror da "era da catástrofe", em A condição humana temos a apresentação de certos traços sombrios visíveis na "era de ouro" subsequente à catástrofe e que são formadores da ordem ocidental que se espraiaria por todo o globo depois do fim da URSS. Campos de concentração não foram vistos em larga escala desde 1945, mas certo domínio totalitário se desenvolveu no seio da ordem ocidental por meio da redução dos seres humanos ao trabalho e à manutenção da vida, cuja temporalidade circular, facilmente previsível e controlável lastreia o sinistro arranjo entre uma definição do humano a partir da manutenção da vida e do interesse, o desaparecimento gradual do trabalho e do emprego, e as formas contemporâneas de controle exercido remotamente. Ao horror dos campos de concentração, para onde a Lei destinava os expulsos do mundo dos humanos, seguiu-se o horror econômico, em que outra Lei seleciona quem poderá realizar a manutenção da própria vida. Em ambos os casos, a esta definição feita pela Lei segue-se certo discurso científico de cunho racista, histórico ou econômico e, nas condições da vitória do animal laborans,

\footnotetext{
a capacidade para a ação, pelo menos no sentido de liberar processos, (...) se tornou prerrogativa dos cientistas, que ampliaram o âmbito das relações humanas a ponto de extinguir a consagrada linha divisória entre o mundo humano e o mundo natural. (...) Mas falta à ação dos cientistas, que agem na natureza tomando o ponto de vista do universo e não da rede de relações humanas, o caráter revelador da ação, bem como a habilidade de produzir histórias e se tornar histórica, que juntas formam a própria fonte de onde emerge o sentido para dentro da existência humana e a ilumina. Neste aspecto existencialmente mais importante, também a ação se tornou uma experiência para poucos privilegiados... ${ }^{23}$
}

Por meio do conhecimento das leis econômicas, ao qual apenas uma elite tem acesso, este discurso científico tem sido importante aliado no controle de massas de indivíduos atomizados em busca da manutenção de seus empregos ou de suas vidas. Se considerarmos que a diferença entre a tirania e o totalitarismo não é a extensão do deserto, mas a existência de uma lógica capaz de colocar em movimento os indivíduos dispersos no deserto, o trabalho e a lógica do interesse aparecem como um assustador elemento totalitário em plena ordem ocidental, uma vez que recolhem estes átomos formando massas com movimento determinado. Embora a solidão seja a experiência básica destes indivíduos trabalhadores,

${ }^{23}$ Arendt, The Human Condition, p.324 
seus movimentos são interconectados e formam uma totalidade orgânica que costumamos chamar de "A economia nacional" ou "A economia mundial". Thatcher afirmava ver apenas indivíduos e famílias, não sociedade, mas gerenciava a totalidade da economia britânica formada por estes átomos dispersos que se movimentam de modo administrável. Tomando a sociedade como um ser inteiramente conectado, o interesse exacerbado ganha uma organicidade, não como relações humanas significativas entre os indivíduos, mas como partes de um interesse que não é classe, mas da "força natural".

\begin{abstract}
A questão é que atualmente até mesmo o último vestígio de ação nisto que estamos fazendo, a motivação implícita do auto interesse, desapareceu. Sobrou apenas a "força natural", a força do próprio processo vital, ao qual todos os homens e todas as atividades humanas estavam igualmente submetidas (...) e cujo único objetivo, se é que há algum, é a sobrevivência da espécie animal do homem. ${ }^{24}$
\end{abstract}

O fato de a preocupação central de governos, capitalistas, empregados e desempregados se expressar na metáfora biológica do "crescimento econômico" evidencia que a proximidade entre política e natureza, cujos dramáticos desdobamentos nós conhecemos, permanece firme no interior da ordem que se concebeu como resistência aos governos totalitários. De fato, governos totalitários não se repetiram desde o fim da segunda grande guerra - com a possível exceção da $\mathrm{China}^{25}$ - , mas este êxito não pode evitar a percepção de que persistem entre nós formas de domínio totalitário, como o engajamento completo de todos no movimento ordenado que leva ao crescimento econômico e é gerenciado remotamente por uma elite cada vez mais distante daquilo que controla. A centralidade do crescimento expressa bem a redução do ser humano a seu aspecto biológico e, se conjugada com o engodo que está na base do horror econômico, constataremos com exatidão o risco do que estamos fazendo.

É desta forma, portanto, que Hannah Arendt desdobra sua crítica de Hitler e Stalin em uma aguda e preocupante análise do mundo livre. Com a mudança do registro da "análise política" para o da "fillosofia", tornou-se possível perceber que a questão do tamanho do Estado em relação à sociedade e ao mercado é secundária e contribui muito menos do que se imaginava para a luta contra o totalitarismo. Um dos resultados deste ponto de vista é um embaralhamento da oposição entre totalitarismo e democracia que sustentou a Guerra Fria e ainda sustenta certa ideologia de origem liberal. Para que isto fosse possível, no entanto, foi

\footnotetext{
${ }^{24}$ Arendt, The Human Condition, p.321

${ }^{25}$ Cf. supra nota 34 do primeiro capítulo.
} 
necessário que a análise feita a partir deste outro registro não reafirmasse a antiga hostilidade da filosofia contra a política, hostilidade fundadora da tradição de filosofia política. Ou seja, foi necessário ir contra a filosofia para poder se colocar contra a superioridade do tempo circular que dá sentido à vida e, ato contínuo, elaborar um grande elogio da temporalidade aberta que estrutura a ação. A condição humana é, portanto, a afirmação da ação contra o totalitarismo, afirmação que só faz sentido a partir deste outro registro, de onde se pode ver com clareza que a temporalidade aberta guarda consigo, ontologicamente, a certeza de que um outro mundo sempre é possível. Ora, considerando os temas e os termos que constituem este outro registro, que nome dar a ele se não o de filosofia? 


\section{Bibliografia}

Obras de Arendt

- ARENDT, H - Love and Augustine. Chicago: The University of Chicago Press, 1998.

- _ _ Rahel Varnhagen: judia alemã na época do romantismo. Rio de Janeiro: Relume Dumará, 1994.

- _ _ The Origins of Totalitarianism. New York: A Harvest Book, 1994

- — Elemente und Ursprünge totaler Herrschaft. München: Piper, 2009

- — "Totalitarianism" in: ARENDT, H - The Origins of Totalitarianism. New York: Schocken Books, 2004, pp.617-8.

- _ - "Concluding Remarks" in: ARENDT, $\mathrm{H}$ - The Origins of Totalitarianism. New York: Schocken Books, 2004, pp.618-32.

- _ _ "Project: Totalitarian Elements in Marxism". Container 19.12. Hannah Arendt-Zentrum, Carl von Ossietzsky Universität, Oldenburg. 1952

- _ _ - "Carta à Guggenheim Foundation de 29 de janeiro de 1953". Container 19.12. Hannah Arendt-Zentrum, Carl von Ossietzsky Universität, Oldenburg. 1953

- _ _ - Karl Marx and the Tradition of Western Political Thought". Hannah Arendt Papers, Manuscript Division, Library of Congress, Washington, D.C. 1953b. Disponível no endereço: https://memory.loc.gov/ammem/arendthtml/arendthome.html

- _ _ - The Human Condition. Chicago: The University of Chicago Press, 1998

- — A condição humana. São Paulo: Forense Universitária, 2014

- — Vita activa. München: Piper, 2010

- — _ La condition de l'homme moderne. Paris: Calmann-Lévy, 1983

- — - - Between Past and Future. New York: Penguin Books, 2006.

- — - On Revolution. New York: Penguin Books, 2006.

- — - Eichmann in Jerusalem. New York: Penguin Books, 2006.

- — Men in Dark Times. San Diego-New York-London: A Harvest Book, 1983

- - - Crisis of the Republic. Penguin Books, 1972

- — The Life of the Mind. San Diego, New York, London: A Harvest book / Harcourt Inc, 1978

- _ Lectures on Kant's Political Philosophy, The University of Chicago Press, Chicago, 1992

- — Essays in Understanding: 1930-1954 - Formation, Exile, and Totalitarianism. New York: Harcourt, Brace \& Co., 1994.

- _ _ _ Responsibility and Judgement. New York: Schocken Books, 2003.

- — A promessa da política. Rio de Janeiro: Difel, 2009

- — — Escritos judaicos. Barueri-São Paulo: Amarilys, 2016.

- - - -Sobre Hannah Arendt" in: Inquietude. Goiânia, vol. 1 n. 2, ago/dez 2010.

- ARENDT, H / JASPERS, K - Briefwechsel: 1926-1969. München-Zurich: Piper, 1993

- ARENDT, H / HEIDEGGER, M - Correspondência: 1925-1975. Rio de Janeiro: Relume Dumará, 2001.

\section{Bibliografia secundária}

- ABENSOUR, M. - Hannah Arendt contre la philosophie politique? Paris: sens\&tonka, 2006

- ADLER, L. - Nos passos de Hannah Arendt. Rio de Janeiro e São Paulo: Record, 2007.

- AGAMBEN, G. - O que resta de Auschwitz: o arquivo e a testemunha (Homo Sacer III). São Paulo: Boitempo, 2008.

- AGAMBEN, G. / PIAZZA, V. — L'ombre de l'amour: le concept d'amour chez Heidegger. Paris: Payot \& Rivages, 2003.

- AMIEL, A - "Hannah Arendt lectrice de Montesquieu" in: Revue Montesquieu. N.2 (1998), 119-38. 
- APPleBAUM, A - Gulag: uma história dos campos de prisioneiros soviéticos. São Paulo: Ediouro, 2004.

- AUBENQUE, P - "Du débat de Davos (1929) à la querelle parisienne sur l'humanisme (1946-1968): genèse, raisons et posterité de l'anti-humanisme heideggérien. In: PINCHARD, B - Heidegger et la question de l'humanisme: faits, concepts, débats. Paris: PUF, 2005, pp. 227-38

- BAHER, P - "Debating Totalitarianism: An Exchange of Letters Between Hannah Arendt and Eric Voegelin" in History and Theory, n. 51 (October 2012), 364-380.

- BALESTRA, Vinícius Batelli de Souza. Hannah Arendt, leitora de Montesquieu: ensaio sobre o totalitarismo e as revoluções. 2016. 148 f. Dissertação (Mestrado) - Curso de Direito, Universidade Federal de Minas Gerais, Belo Horizonte, 2016.

- BALIBAR, E - "L'Anti-Marx de Michel Foucault" IN: LAVAL, C (et. alii) - Marx \& Foucault: lectures, usages, confrontations. Paris: La Découverte, 2015 pp. 84-102

- BARTHES, R - "La mort de l'auteur" IN: BARTHES, R - Le bruissement de la langue: essais critiques IV. Paris: Seuil, 1984 pp. 61-7.

- BATAILlE, G - "Le sens de l'industrialisation soviétique" in Critique, 20, janeiro de 1948, pp. 59-76.

- BENHABIB, S - The Reluctant Modernism of Hannah Arendt. Rowman \& Littlefield Publishers INC, 2003.

- BENJAMIN, W - "Teorias do fascismo alemão: sobre a coletânea 'Guerras e guerreiros' editada por Ernst Jünger." IN: Obras escolhidas: magia e técnica, arte e política. São Paulo: Brasiliense, 1985. pp. 61-72.

- BIGNOTTO, N - "A contingência do novo" In: NOVAES, A (org.) - A condição humana: as aventuras do homem em tempos de mutações. Rio de Janeiro: Agir; São Paulo: Edições SESC-SP, 2009. pp .221-40.

- _ _ _Hannah Arendt e a revolução francesa" in: $O$ que nos faz pensar n²9, maio de 2011, pp.41-58.

- _ _ — "Hannah e sua biógrafa". Folha de São Paulo (Mais!), edição de 15 de abril de 2007.

- BIGNOTTO, N / MORAES, E.J (org.) - Hannah Arendt: diálogos, reflexões, memórias. Belo Horizonte: UFMG, 2003.

- BOUTOT, A - Introdução à filosofia de Heidegger. Publicações Europa-América, sem data.

- BRUNEL, P. - Éclats de la violence: pour une lecture comparatiste des 'Illuminations' d'Arthur Rimbaud. Paris: José Corti, 2004.

- BURNS, J. F. - "From Banality to Audacity" in: The New York Times (Week in Review) 11 de dezembro de 2005. Disponível em: http://www.nytimes.com/2005/12/11/weekinreview/from-banality-to-audacity.html (acessado em 13 de novembro de 2017).

- CAlVET MAGAlHÃES, T - "A atividade humana do trabalho (labor) em Hannah Arendt" Ética \& Filosofia Política, de Juiz de Fora, vol. 9, n.1, jun. 2006.

- CANOVAN, M - The Political Thought of Hannah Arendt. New York \& London: Hartcourt Brace Jovanovich, 1974.

- — Hannah Arendt: A Reinterpretation of Her Political Thought. Cambridge University Press, 1994.

- _ - "Introduction" in: ARENDT, H - The Human Condition. Chicago: The University of Chicago Press, 1998. pp. vii-xx.

- CASSIRER, E / HEIDEGGER, M - Débat sur le kantisme et la philosophie (Davos, mars 1929) et autres textes de 1929-1931 présentés par Pierre Aubenque. Paris: Beauchesne, 1972.

- _ _ "Disputa de Davos entre Ernst Cassirer e Martin Heidegger" in: Cadernos de Filosofia Alemã. v. 22; n. 1. pp.157-178.

- CERBONE, D - Fenomenologia. São Paulo: Vozes, 2013

- CORREIA, A - "Política e pobreza: com Arendt, contra Arendt" IN Cadernos de Ética e Filosofia Política. n. 28, pp. 109-21.

- _ _ Hannah Arendt e a modernidade: política, economia e a disputa por uma 
fronteira. Rio de Janeiro: Forense Universitária, 2014.

de 2007 (pp.4-5)

— "A biógrafa Arendt é mal biografada" in. Jornal do Brasil, edição de 28 de abril

- COURTINE-DÉNAMY, S - Hannah Arendt. Lisboa: Piaget, sem data.

- DARDOT, P / LAVAL, C - A nova razão do mundo: ensaio sobre a sociedade neoliberal. São Paulo: Boitempo, 2016.

- DASTUR, F - Heidegger et la question du temps. Paris: PUF, 1990

- DREYFUS, H / WRATHALL, M - A Companion to Heidegger. Blackwell Publishing, 2005

- DUARTE, A - "Arendt e a modernidade: proximidade na distância em relação a Heidegger" in Vidas em Risco. Rio de Janeiro: Forense Universitária, 2010, pp. 43-67

- _ _ _ O pensamento à sombra da ruptura. São Paulo: Paz\&Terra, 2000.

- — - - "Hannah Arendt e o pensamento político: a arte de distinguir e relacionar conceitos" in. Argumentos. ano 5, n. 9 - Fortaleza, jan./jun. 2013.

- ECCEL, D. - Entre política e metafísica: filosofia e política em Hannah Arendt e Eric Voegelin. 251p. Tese (Doutorado) - Curso de Filosofia, Universidade Federal de Santa Cararina, Florianópolis, 2015.

- EMBREE, L et alli. - Encyclopedia of Phenomenology. Kluwer Academic Publishers.

- FARIAS, V - Heidegger e o nazismo. São Paulo: Paz \& Terra, 1988.

- FAYE, E - Heidegger: a introdução do nazismo na filosofia. São Paulo: É Realizações, 2015.

- - - Arendt et Heidegger: extermination nazie et destruction de la pensée. Paris: Albin Michel, 2016.

- FISCHER, J - Philosophische Antropologie: Eine denkrichtung des 20. Jahrhudenrts. Freiburg/München Alber Studienausgabe, 2009.

- FOUCAULT, M - Segurança, território, população. São Paulo: Martins Fontes, 2008.

- _ - Naissance de la biopolitique. Paris: Seuil/Gallimard, 2004.

- FRIEDMAN, M - A Parting of Ways: Carnap, Cassirer, and Heidegger. Chicago and La Salle: Open Court, 2000.

- FRIEDRICH, C / BRZEZINSKI, Z - Totalitarismo e autocracia. Rio de Janeiro: Edições GRD, 1965.

- FURET, F - Le passé d'une ilusion: essai sur l'idée communiste au XXe siècle. Paris: Robert Laffont \& Calmann-Lévy, 1995.

- _ _ _Les Différents aspects du concept de totalitarisme" in TRAVERSO, E - Le Totalitarisme: le XXe siècle en débat. Paris: Éditions du Seuil, 2001, pp. 872-8.

- FURET, F / NOLTE, E - Fascismo y comunismo. Fondo de Cultura Económica, 1999.

- GARCIA, R - "Mito e liberdade: a crítica da cultura contra o totalitarismo político". 2015. 189f. Tese (doutorado) - Curso de Filosofia, Universidade de São Paulo, São Paulo.

- GIDE, A - Retour de l'U.R.S.S. seguido de Retouches à mon "Retour de l'U.R.S.S". Paris: Gallimard, 1936 e 1937 (reimpresso em 2015).

- GORDON, P - Continental Divide: Heidegger, Cassirer, Davos. Harvard University Press, 2010.

- GRUNENBERG, A - Hannah Arendt et Martin Heidegger: histoire d'un amour. Paris: Payot, 2012.

- GUIGNON, C (ed.) - The Cambridge Companion to Heidegger. Cambridge, 2006 (2nd Edition).

- HABERMAS, J - "El concepto de poder de Hannah Arendt". in: Perfiles filosófico-políticos. Madrid: Taurus, 1984, pp.205-22

- HARVEY, D - A condição pós-moderna. São Paulo: Loyola, 1992.

- HILL, M - Hannah Arendt: The Recovery of the Public World. New York: St. Martin's Press, 1978.

- HEIDEGGER, M - Ser e tempo. Campinas, SP: Editora da Unicamp; Petrópolis, RJ: Vozes, 2012 (edição bilíngue).

- _ - "Carta sobre o humanismo" in Marcas do caminho. São Paulo: Vozes, 2008. pp. 326-76 (Trad. Ernildo Stein e Enio Paulo Giachini). 
Emmanuel Carneiro Leão)

- Sobre o humanismo. Rio de Janeiro: Tempo Brasileiro, 1967. (Trad.

- — Über den Humanismus. Frankfurt am Main: Vittorio Klostermann, 1947. Ijuí: Ed. Unijuí, 2005. pp. 191-232 (Trad. Paulo R. Schneider)

- _ - "Die Zeit des Weltbildes" in Holzwege. Frankfurt am Main: Vittorio Klostermann, 1972. pp. 69-104.

- HEUER, W / HEITER, B / Rosenmüller, S (org.) - Arendt Handbuch: Leben, Werk, Wirkung. Stutgart-Weimar: J.B. Metzler Verlag, 2011.

- HUSSERL, E - Recherches logiques. Paris: PUF, 1959.

- INWOOD, M - A Heidegger Dictionary. Oxford: Blackwell Publishers, 1999

- JARVINS, S - Adorno: A Critical Introduction. Polity Press, 1998.

- JUDT, T - "Hannah Arendt e o mal" in. Reflexões sobre um século esquecido (1901-2000). Rio de Janeiro: Objetiva, 2010, pp. 91-112

- _ _ - "O 'problema do mal' na Europa do pós-guerra" in: Quando os fatos mudam — Ensaios 1995-2000. Rio de Janeiro: Objetiva, 2015, pp.153-66.

- JÜNGER, E - "La mobilisation totale" in: TRAVERSO, E - Le Totalitarisme: le XXe siècle en débat. Paris: Éditions du Seuil, 2001, pp. 111-22.

- _ _ Tempestades de aço. [trad. Marcelo Backes]. São Paulo: Cosac Naify, 2013.

- KATEB, G - "Freedom and Worldliness in the Thought of Hannah Arendt" in: Political Theory, vol. 5 n. 2 (May, 1977), pp. 141-82 (disponível em: http://www.jstor.org/stable/190726 )

- _ "Arendt and Individualism" in: Social Research. Vol. 61, No. 4 (Inverno, 1994), pp. 765-94.

- KING, R - Hannah Arendt and America. Chicago: The University of Chicago Press, 2015.

- KHLEVNYUK, O - "The Economy of the OGPU, NKVD, and MVD of the USSR, 19301953" in. GREGORY, P.R / LAZAREV, V. - The Economics of Forced Labor: The Soviet Gulag. Hoover Press, pp.43-66.

- LAFER, C - Hannah Arendt: pensamento, persuasão e poder. São Paulo: Paz e Terra, 2003.

- _ _ _ "Hannah Arendt: vida e obra" in: Ensaios liberais. São Paulo: Siciliano, 1991, pp. 115-33.

- _ _ - A política e a condição humana" in ARENDT, H - A condição humana. Rio de Janeiro: Forense Universitária, 2007 (10 edição), pp. 341-52.

- LEFORT, C — "La logique totalitaire" in: L'invention démocratique: les limites de la domination totalitaire. Paris: Fayard, 1981, pp. 85-106.

- _ _ _ _'image du corps et le totalitarisme" IN: L'invention démocratique. Paris: Fayard, 1981 pp. 159-176

- _ _ _ _La question de la démocratie" in: Essais sur le politique (XIXe - Xxe siècles). Paris: Seuil, 1986, pp. 17-32.

- _ _ _Les droits de l'homme et l'État providence" IN: Essais sur le politique: $x i x-x x$ siècles. Paris: Seuil (points), 1986. pp. 33-63.

- _ _ "Hannah Arendt et la question du politique" in: Essais sur le politique (XIXe Xxe siècles). Paris: Seuil, 1986, pp. 64-78.

- _ _ _ "Thinking with and against Hannah Arendt" in: Social Research. Vol. 69, n. 2, Summer 2002, pp. 447-59.

- _ _ _ "Loi de mouvement et idéologie selon Hannah Arendt" in: La complication: retour sur le communisme. Paris: Fayard, 1999, pp. 193-210.

- LEOPOLdo E SILVA, F - "Martin Heidegger e a técnica" in: Scientice Studia, São Paulo, v. 5, n. 3, p. 369-74, 2007.

- LORIES, Danielle - "Pour une phénoménologie politique de l'art. L'oueuvre et le monde chez Arendt" IN: DUPOND, P / COURNARIE, L (org.) Phénoménologie: um siècle de philosophie. Paris: Ellipses, 2002. pp. 217-32.

- MARCHART, O - Post-Foundational Political Thought. Edinburg: Edinburg University Press. 2007. 
- MARX, K - Manuscritos econômico-filosóficos. São Paulo: Boitempo, 2010.

- _ _ O O 18 de Brumário de Luís Bonaparte. São Paulo: Boitempo, 2011.

- —_Grundrisse. São Paulo: Boitempo, 2011.

- — O capital. São Paulo: Nova Cultural, 1985.

- MARX, K / ENGELS, F - A ideologia alemã. São Paulo: Boitempo, 2007.

- MONGIN, O - "La réception d'Arendt em France" in Politique et pensée: colloque Hannah Arendt (1988). Paris: Payot \& Rivages, 2004.

- MORAN, D - "Hannah Arendt: the phenomenology of the public sphere." IN Introduction to Phenomenology. London: Routledge, 2000, pp. 287-319.

- MÜNSTER, A - Hannah Arendt contre Karl Marx?. Paris: Hermann, 2008.

- PASCAL, B - "De l'esprit géométrique" in. Oeuvres complètes II (Bibliotèque de la Pléiade). Paris: Gallimard, 2000, pp. 154-82

- PASQUA, H - Introdução à leitura do "Ser e tempo" de Martin Heidegger. Lisboa: Instituto Piaget, 1997.

- REMARQUE, E. M - Nada de novo no front [trad. Helen Rumjanek]. Rio de Janeiro; Record/Altaya, 1996.

- RICOEUR, P - "Préface" in: ARENDT, H - La condittion de l'homme moderne. Paris: Calmann-Lévy, 1983 (republicado em RICOEUR, P - Lectures 1: autour du politique. Paris: Seuil, 1991, pp. 43-66).

- ROUSSET, D - O universo concentracionário. Lisboa: Antígona, 2016.

- SAFATLE, V - "Sobre a potência política do inumano: retornar à crítica do humanismo". In: NOVAES, A (org.) - A condição humana: as aventuras do homem em tempos de mutações. Rio de Janeiro: Agir; São Paulo: Edições SESC-SP, 2009. pp . 199-220.

- SAFRANSKI, R - Heidegger: um mestre da Alemanha além do bem e do mal. São Paulo: Geração editorial, 2000

- SARTRE, J-P. - L'existencialisme est un humanisme. Paris: Gallimard (folio/essais), 1996.

- SEligMANN-SILVA, M. / NESTROVSKI, A - Catástrofe e representação. São Paulo: Escuta, 2000.

- SPIEGELBERG, H - The Phenomenological Movement: A Historical Introduction. Martinus Nijhoff Publishers, 1984.

- TAMINIAUX, J - La fille de la Thrace et le penseur professionnel: Arendt et Heidegger. Paris: Payot, 1992.

- TOOZE, A - The Wages of Destruction: The Making and the Breaking of the Nazi Economy. New York: Penguin Books, 2008.

- TRAVERSO, E - "Avant-Propos" e "Introduction" in: Le Totalitarisme: le XXe siècle en débat. Paris: Éditions du Seuil, 2001, pp. 5-110.

- VAZ, H. C. L. - Antropologia Filosófica I. São Paulo: Loyola, 1998.

- VILlA, D - Arendt and Heidegger: The Fate of the Political. Princeton: Princeton University Press, 1996.

- _ _ - "The Anxiety of Influence: On Arendt's Relationship to Heidegger" in: Politics, Philosophy, Terror: Essays on the Thought of Hannah Arendt. Princeton: Princeton University, 1999, pp. 61-86.

- VOEGELIN, E - "The Origins of Totalitarianism" in The Collected Works of Eric Voegelin. Columbia and London: University of Missouri Press, 2000. Vol 11, pp 8-23.

- _ - "The Origins of Scientism" in The Collected Works of Eric Voegelin. Columbia and London: University of Missouri Press, 2000. Vol 10, pp 168-96.

- WACHSMANN, N - KL: A History of the Nazi Concentration Camps. New York: Farrar, Straus and Giroux, 2016.

- WEISMAN, T - Hannah Arendt and Karl Marx: On Totalitarianism and the Tradition of Western Political Thought. Lanham: Lexington Books, 2014.

- WOLIN, R - Heidegger's Children. Princeton and Oxford: Princeton University Press, 2001

- YOUNG-BRUHEL, E - "From the Pariah's Point of View: Reflections on Hannah Arendt's Life and Work" in : HILL, M - Hannah Arendt: The Recovery of the Public World. New York: St. Martin's Press, 1978. pp. 3-26. 
- Hannah Arendt: For the Love of the World. New Haven \& London: Yale University Press, 2004 (second edition).

- — Why Arendt Matters. New Haven-London: Yale University Press, 2006

- ŽIŽEK, S - Alguém disse totalitarismo? Cinco intervenções no (mau) uso de uma noção. São Paulo: Boitempo, 2013. 